\title{
ASPECTOS DA PRÁTICA DO VIOLONCELO NA VISÃO DE INSTRUMENTISTAS-EDUCADORES
}

Dissertação apresentada ao Programa de Pós-Graduação em Música, Área de Concentração Musicologia, Linha de Pesquisa História, Estrutura e Estilo na Música, da Escola de Comunicações e Artes da Universidade de São Paulo, como exigência parcial para a obtenção do Título de Mestre em Música, sob a orientação do Prof. Dr. Marcos Branda Lacerda.

São Paulo 2008 


\section{ASPECTOS DA PRÁTICA DO VIOLONCELO NA VISÃO DE INSTRUMENTISTAS-EDUCADORES}

Dissertação apresentada ao Programa de Pós-Graduação em Música, Área de Concentração Musicologia, Linha de Pesquisa História, Estrutura e Estilo na Música, da Escola de Comunicações e Artes da Universidade de São Paulo, como exigência parcial para a obtenção do Título de Mestre em Música, sob a orientação do Prof. Dr. Marcos Branda Lacerda.

São Paulo 2008 
BANCA EXAMINADORA 
Em memória de Mstislav Rostropovich 


\section{AGRADECIMENTOS}

Agradeço ao meu pai, Aguinaldo Maciente, e à minha mãe, Maria Aparecida Nogueira Maciente, pelo imenso incentivo dado aos estudos, às artes, ao trabalho árduo e à honestidade, que me deram meios de chegar a mais esta importante etapa. Ao meu irmão, Prof. Dr. Aguinaldo Nogueira Maciente, que me instigou a paixão pelos livros, e me conduziu à vida acadêmica.

A meu amado marido, Luis Afonso "Montanha", por ser meu alicerce na vida, e pelas inesgotáveis conversas sobre música e interpretação. Aos meus "amigos-filhinhosenteados", Daniel Eugênio Afonso e Filipe Eugênio Afonso, por serem sorriso, carinho e aprendizados que iluminam minha vida.

Agradeço principalmente ao orientador Prof. Dr. Marcos Branda Lacerda, pela disponibilidade, imensa ajuda, pelas críticas e informações valiosas, e pela enorme paciência no período de elaboração da Dissertação e durante o Curso.

Aos Profs. Drs. Fernando Iazzetta, Eduardo Monteiro e Émerson de Biaggi, pelas valiosas sugestões. Agradeço também a todos os professores que contribuíram para a minha formação, em todas as etapas, sem exceção. Agradeço em particular àqueles que considero como meus valiosos mestres: Mstislav Rostropovich, Raiff Dantas Barreto, Betina Stegmann, Marcelo Jaffé, Profs. Drs. Ecléa e Alfredo Bosi, Profa. Dra. Nádia Battella Gotlib, Profs. Drs. Gláucia D’Olim Marote Ferro e João Teodoro D’Olim, Prof. Marcos Rojo Rodrigues, Profa. Maria Teresa Magalhães e Monja Coen, por me ensinarem inúmeras lições de generosidade, amor ao próximo e ao conhecimento, e me "incitarem" a me aperfeiçoar sempre e continuar lutando por um mundo melhor.

A todos do Departamento de Música da USP e da ECA que contribuíram para a elaboração deste trabalho. Aos grandes colegas do Quarteto Nobilis: Silvia Velludo, José Quirino e Margareth Yahagi, pela amizade e incentivo constante e incondicional. Ao colega Fernando Florestan pela grande ajuda na formatação e nos Anexos.

Ao Prof. Dimos Goudaroulis (UNICAMP) e ao Prof. Fábio Presgrave (UNESP) pela amizade, simpatia e valorosa contribuição: não foram entrevistas, foram aulas!

Finalmente, e de modo particular, ao grande ídolo, mestre e amigo, Prof. Robert Suetholz, por ter me ensinado tudo o que sei sobre violoncelo, da maneira mais generosa possível. 


\section{RESUMO}

O objetivo deste trabalho é apresentar idéias e hipóteses de destacados violoncelistas e professores de violoncelo sobre o processo de aprendizagem e o ensino da técnica e da interpretação do instrumento, com a finalidade de proporcionar importantes reflexões sobre o assunto, meios de pesquisa no instrumento, além de ser uma iniciativa de pesquisa sobre e para o meio violoncelístico brasileiro.

Fundamentalmente, este trabalho consiste na apreciação da literatura específica sobre o instrumento, produzida, na maioria das vezes, por mestres consagrados. Isso foi complementado por entrevistas e por idéias transmitidas oralmente, por meio de aulas de violoncelo (talvez o mais importante meio de transmissão de conhecimentos musicais), além da experiência pessoal desta autora, em sua prática docente.

Resultou desta pesquisa uma grande quantidade de dados, divergentes e convergentes, sobre os inúmeros aspectos do estudo do violoncelo, tais como: maneiras de se pensar o estudo, relaxamento, postura, respiração, escolas de técnica de arco, vibrato, mão esquerda, construção da interpretação, assim como problemas referentes ao ensino e ao estudo do violoncelo no Brasil, bem como idéias para possíveis soluções.

Palavras-chave: violoncelo; cordas; ensino; aprendizagem; técnica. 


\begin{abstract}
The goal of this work is to present ideas and hypothesis of remarkable cellists and professors of the cello about the learning process and the teaching of technique and interpretation of the instrument, with the objective of generating important reflections about these issues, ways of researching on the instrument, as well as being a first step towards research about and for Brazilian cellists.

The ideas presented have been reached by bibliographical research, interviews, transmitted orally through cello lessons (perhaps the most important way of transmitting musical knowledge), and also obtained by the personal experience of this author over her teaching practice.

A great amount of data has resulted from this research, including convergent and divergent ideas dealing with the innumerable aspects of the process of cello study, such as: ways of developing cello study, relaxation with the instrument, posture, breathing, schools of bow technique, vibrato, the left hand, construction of interpretation, problems encountered by those teaching and learning cello in Brazil, as well as ideas for possible solutions to these problems.
\end{abstract}

Key-words: Cello; strings; teaching, learning; technique. 


\section{SUMÁRIO}

Introdução 1

Primeiro Capítulo - Idéias de cinco pensadores sobre o ensino e a prática do violoncelo. 6

1. 1. Victor Sazer e a prática de violoncelo sem dor. 9

1. 2. Paul Tortelier, o polegar e a resolução de problemas práticos de técnica............... 25

1. 3. William Pleeth, o estudo e a interpretação do violoncelo..................................... 35

1. 4. Gerhard Mantel e os movimentos corporais aplicados ao violoncelo..................... 50

1. 5. Mstislav Rostropovich: compilação das idéias transmitidas em quatro aulas........ 62

Segundo Capítulo - Cruzamento dos dados apresentados: divergências e convergências. 79

2. 1. As escolas de técnica de arco e os diferentes tipos de posicionamento das mãos: um breve panorama. 83

2. 2. Conceitos importantes discutidos ligados ao processo de aprendizagem e à

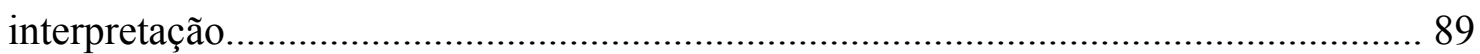

2. 3. Conceitos técnicos importantes discutidos.............................................................. 98

2. 4. Idéias únicas tratadas por cada autor pesquisado............................................... 107

2. 5. Semelhanças em todos os autores..................................................................... 115

2. 6. Quadro comparativo de aspectos discutidos pelos violoncelistas....................... 116

Terceiro Capítulo - Ensino e a aprendizagem do violoncelo em nosso país, especificamente em São Paulo: visões de educadores do violoncelo.

3.1. Entrevistas 120

3. 1. 1. Entrevista com o Prof. Robert Suetholz (USP) ….......................................... 122

3. 1. 2. Entrevista com o Prof. Dimos Goudaroulis (UNICAMP).............................. 130

3. 1. 3. Entrevista com o Prof. Fábio Presgrave (UNESP) .......................................... 160

3. 2. Cruzamento de dados e observações sobre as entrevistas realizadas e os Capítulos anteriores 175 
3. 2. 1. Pontos de concordância entre os entrevistados

3. 2. 2. Pontos de divergência entre os entrevistados.

3. 2. 3. Idéias marcantes, apresentadas apenas por um dos Professores entrevistados 184

Quarto Capítulo - Reflexões sobre aspectos do ensino do violoncelo 189

4. 1 . O violoncelista "pesquisador" 190

4. 2. Alguns problemas do ensino do violoncelo no Brasil 194

4. 3. Lecionar o violoncelo: a transmissão oral de mestre para aprendiz. 195

Considerações Finais. 201

Bibliografia 207

Anexos i

1. Exercícios propostos a esta pesquisadora por Mstislav Rostropovich (digitados)...... ii

2. Cópia dos exercícios originais de Rostropovich (escaneados) .................................. v

3. Escolas de Técnica de Violoncelo, por Dmitry Markevitch...................................... viii 


\title{
INTRODUÇÃO
}

\author{
"Há duas maneiras de se desprezar a arte- \\ odiando-a, on então amando-a com moderação". \\ OSCAR WILDE
}

Este trabalho pretende expor hipóteses de destacados autores, violoncelistas e professores dedicados à arte do violoncelo, comparando-as e comentando-as, proporcionando um ponto de partida a um embasamento teórico a respeito da técnica básica, da prática e da interpretação, a fim de facilitar o ato de estudar, aprender e ensinar o violoncelo.

Em resumo, a organização do trabalho será feita da seguinte maneira:

O Primeiro Capítulo conterá idéias pertinentes, destacadas de livros de quatro pensadores, Victor Sazer, Paul Tortelier, William Pleeth, Gerhard Mantel, e de quatro aulas e conversas concedidas a esta pesquisadora por Mstislav Rostropovich, realizadas em dezembro de 2000 (Filadélfia - EUA) e abril de 2001 (Buenos Aires - Argentina), a respeito do ensino e da prática do violoncelo. Os principais livros pesquisados serão, portanto: New Directions in Cello Playing, de Victor Sazer, El Violonchelo, así interpreto, así enseño, de Paul Tortelier, Cello, de William Pleeth e Cello Technique, de Gerhard Mantel.

O Segundo Capítulo apresentará um panorama sobre as diferentes escolas de técnica de arco e modos de uso da mão esquerda usadas na interpretação do violoncelo, apontando algumas diferenças no tipo de sonoridade obtida, devido às escolhas feitas, seus prós e contras. Cruzará, então, os dados encontrados nos quatro autores e no violoncelista abordado, expondo convergências e divergências das idéias apresentadas. Trabalhará com textos de outros autores, com base em bibliografia ligada à técnica e à interpretação de instrumentos de cordas, relacionando-os com os textos pesquisados no 
Primeiro Capítulo, apontando divergências e convergências, a fim de embasar a comparação entre eles.

O Terceiro Capítulo tratará do ensino do violoncelo em nosso país, especificamente em São Paulo, trazendo entrevistas de três violoncelistas e docentes das Universidades públicas de São Paulo: Prof. Robert Suetholz (USP), Prof. Dimos Goudaroulis (UNICAMP) e Prof. Fábio Presgrave (UNESP). Profissionais destacados, dentro desse cenário musical, apresentarão suas opiniões sobre os assuntos anteriormente pesquisados neste trabalho e abordarão suas idéias mais relevantes sobre o violoncelo, suscitando hipóteses de estudo e reflexões sobre o processo de ensino e aprendizagem do instrumento.

Esta pesquisadora acha necessário abordar que a opção por incluir as entrevistas no corpo do trabalho, e não em um Apêndice, como é de costume, se deve ao fato de esta pesquisa valorizar a transmissão oral de conhecimentos como importante material de pesquisa, tornado, com a transcrição autorizada pelos entrevistados, também material bibliográfico.

“O Quarto Capítulo trará reflexões sobre outras hipóteses, sugestões, problemas constatados em sala de aula pela pesquisadora, além de comentários sobre outras leituras feitas, relacionadas ao ensino de cordas, à relação mestre-aprendiz e à arte.

Finalmente, trará as Considerações Finais, a Bibliografia e três itens Anexo, que são os exercícios (escalas, arpejos e exercícios de mão esquerda) que Mstislav Rostropovich escreveu de próprio punho para esta pesquisadora, em versão digitada e em versão original escaneada, bem como um quadro de escolas de técnica de arco, proposto por Dmitry Markevich.

Os livros pesquisados foram escolhidos por terem sido escritos por destacados professores de violoncelo e instrumentistas de renome dentro do meio musical, e também, principalmente, por terem sido escritos com abordagens muito diversas em relação aos subtemas que circundam o macrotema: "técnica de violoncelo".

O objeto desta pesquisa é o violoncelista, enquanto pesquisador em seu processo de aprendizagem, estudo do instrumento e enquanto professor de violoncelo. Por isso, esta pesquisa abordará tópicos relacionados à técnica básica do violoncelo, escolas de técnica de arco, mão esquerda, postura, respiração, interpretação, o ensino e o desenvolvimento da percepção corporal necessária para um violoncelista, apresentando 
idéias divergentes nesses mesmos assuntos abordados, contribuindo para reflexões mais imparciais sobre esses assuntos.

Ainda que, numa Dissertação, a intenção seja, antes de tudo, a imparcialidade, fundamentada em estudo e apresentação de dados e hipóteses, não se deve perder de vista que qualquer pesquisa traz uma visão pessoal dos assuntos abordados pelo pesquisador, que elege as idéias que lhe parecem especialmente úteis ou inovadoras.

Com a apresentação e a comparação dos dados colhidos, pretende-se levantar hipóteses sobre maneiras eficientes de ensinar, aprender e praticar o violoncelo. Ou seja, mostrar problemas comuns relacionados ao estudo e ensino do violoncelo e, com base nas comparações e conclusões feitas, propor idéias de reflexão que poderão ser úteis para violoncelistas, tanto professores quanto alunos.

Ainda é muito escasso o número de violoncelistas brasileiros envolvidos em pesquisas e pós-graduações sobre o instrumento, sua técnica e interpretação, bem como há uma ausência de trabalhos publicados sobre o assunto no país, em contrapartida a uma quantidade significativa de pesquisas, livros, artigos e sites sobre técnica, prática e didática de violoncelo no exterior do Brasil. Isso aponta para uma grande carência de pesquisas em português, direcionadas ao meio musical brasileiro (principalmente e especificamente sobre o violoncelo), meio que tem crescido substancialmente nos últimos anos, sem que haja uma preocupação com a geração de publicações e traduções.

A maior dificuldade encontrada nesta pesquisa foi, portanto, sem dúvida alguma, essa ausência de bibliografia produzida em língua portuguesa sobre os assuntos abordados, além de uma dificuldade muito grande no acesso à literatura estrangeira, para os mesmos fins. Este trabalho pretende, portanto, ser uma iniciativa para suprir essa imensa lacuna, propondo também uma bibliografia de estudo e pesquisa para professores e alunos de instrumentos de cordas, principalmente violoncelistas.

Os autores Marco Antônio Lavigne e Paulo Gustavo Bosísio, em seu artigo "Técnicas fundamentais de arco para violino e viola" (Op. cit., p. 4), afirmam:

\footnotetext{
"Apesar de ser uma atividade que ocupa horas e horas de boa parcela dos músicos de um país, o estudo do instrumento de corda ainda conta com pouco subsídio escrito acerca de sua mecânica, principalmente se considerarmos a extensa bibliografia sobre outras áreas da denominada música erudita. Aliás, uma das características atribuídas a esse estilo de música consiste na transmissão de seu repertório através da escrita (...). A própria musicologia - área que se propõe a produzir conhecimento sobre música por meio da literatura - prioriza aspectos históricos, ou questões relativas à acústica,
} 
estética, rítmica, métrica, harmonia, organologia, pedagogia musical, etc. As descrições de técnicas instrumentais - imprescindíveis para a manutenção dos repertórios - não fazem parte de suas tradições. Em última análise, tais técnicas de produção sonora são transmitidas oralmente, através de uma interação professor e aluno, durante aulas e ao longo das gerações".

Além disso, esses autores também afirmam que "no Brasil, não obstante sua importante tradição na área de cordas, trabalhos escritos em português sobre prática instrumental são raros e de difícil acesso para jovens professores e estudantes."

O objetivo geral do trabalho é descrever hipóteses e possíveis soluções para tais problemas, voltados ao aluno brasileiro, instigando as seguintes perguntas: É possível encontrar meios ou parâmetros para se estudar e ensinar violoncelo de maneira mais rápida e eficiente? Existem soluções passíveis de serem utilizadas por todos? Existem padrões de problemas que podem ser eliminados, após sua conscientização? Quais são as técnicas mais usadas, as escolas de violoncelo? Existe uma escola correta e uma errada? Há uma nova escola, resultante da união de antigas escolas?

O objetivo teórico desta dissertação é ser uma ferramenta de reflexão, que possa gerar maior interesse pelos assuntos ligados à didática, mediante estudo $\mathrm{e}$ questionamentos, levando à realização de seu objetivo prático, que é viabilizar ao estudante e professor brasileiro um trabalho feito para eles, que venha a sanar (ou até mesmo criar) dúvidas e proporcionar soluções de alguns problemas práticos, relativos às formas de estudar e de ensinar o violoncelo. E, possivelmente, também, instigar uma posterior geração de interesse de outros violoncelistas para a criação de suas próprias pesquisas e estudos acadêmicos.

Esta pesquisa, de caráter bibliográfico, vem trazer um panorama teórico de hipóteses sobre os assuntos tratados, outras visões e percepções a respeito dessas leituras feitas.

Quanto ao procedimento, esta é uma pesquisa descritiva, registrando e descrevendo as idéias e dados fornecidos pelos autores e violoncelistas pesquisados, sem manipulá-los, além de ser também uma pesquisa qualitativa, que não faz uso de dados estatísticos, nem tem a pretensão de numerar ou medir unidades ou categorias homogêneas.

A amostragem, portanto, partirá da bibliografia pesquisada, das entrevistas realizadas, da compilação de idéias expostas nas aulas, bem como do levantamento de problemas enfrentados pela pesquisadora em sua prática como estudante de violoncelo, 
intérprete e docente. Quanto ao gênero, esta pesquisa pode ser considerada teórica, pois estuda teorias propostas por outros autores, violoncelistas e por esta autora, além de ser também de gênero metodológico, por abordar o modo de se ensinar e aprender violoncelo, no que diz respeito a suas técnicas.

Convém dizer que todas as traduções de citações, tanto de textos em inglês, quanto em espanhol, foram feitas por esta pesquisadora, dada sua experiência anterior na área de Letras, pois a autora é Bacharel em Letras (Espanhol e Portugês), pela FFLCH- USP (1997).

É necessário acrescentar que o período de elaboração desta dissertação foi marcado por dois tristes falecimentos, duas perdas irreparáveis para o meio violoncelístico: Mstislav Rostropovich, que forneceu as informações para grande parte deste trabalho, e Zigmunt Kubala, tão importante para o Brasil quanto Rostropovich foi para o mundo, no que se refere à divulgação do instrumento e de seu repertório, bem como na formação e inspiração dos novos violoncelistas. O Prof. Kubala já havia aceitado realizar a entrevista, que seria aqui apresentada, mas não houve tempo. Faleceu uma semana antes de fazê-la, fato que esta pesquisadora muito lamenta, pois, com certeza, além de ter deixado uma grande lacuna para o meio musical brasileiro, e muita saudade para seus alunos e amigos, suas idéias e comentários teriam enriquecido grandemente esta dissertação. 
Primeiro Capítulo. Idéias de cinco pensadores sobre o ensino e a prática do violoncelo 
Primeiro Capítulo. Idéias de cinco pensadores sobre o ensino e a prática do violoncelo.

"Experiência é o nome que damos a nossos erros".

OSCAR WILDE

"Quem alcança seu ideal vai além dele".

FRIEDRICH NIETZSCHE

A seguir, uma breve descrição dos quatro livros que serão apresentados neste capítulo, além das aulas de Mstislav Rostropovich:

- Victor Sazer (Op. cit., 1995) pesquisa o ensino e aprendizado a partir do subtema do estudo voltado para o corpo, técnicas de relaxamento ao tocar, estudos e pesquisas ergonômicas, voltando-se para a problemática da busca de um estudo sem dor e sem danos físicos, que facilite o aprendizado e até mesmo a interpretação musical, trabalhando, por meio de exercícios aplicados, uma maior interação do conjunto formado por corpo-instrumento-instrumentista. Este livro foi escolhido, principalmente, por tratar de maneira aprofundada a questão da sensação física do músico (no caso específico do violoncelo, ponto que é abordado apenas superficialmente pelos outros três autores, e considerado por esta pesquisadora de extrema relevância para o instrumentista).

- William Pleeth (Op. cit., 2002) aborda problemas reais ocorridos durante sua prática letiva e soluções objetivas usadas por ele inúmeras vezes e constatadas como úteis. O livro é bastante abrangente nas temáticas relacionadas ao instrumento (relata desde problemas de tensão, de educação para crianças, problemas de arco e mão esquerda, postura, entre muitos outros) e defende a "posição inclinada" da mão esquerda, contestada, em seguida, por Paul Tortelier. 
- Paul Tortelier (Op. cit., 1993) apresenta um misto de método de técnica prática e livro teórico (neste caso, é o único método comentado) que trata de temas voltados à postura e técnica básica de arco, com exercícios práticos (corda solta, ponto de contato, respiração, aderência do arco na corda, colocação do instrumento e do arco), mas aborda um aspecto muito diverso: dá importância crucial à colocação (posicionamento e grau de tensão) do polegar da mão esquerda e sua influência sobre a afinação, o vibrato, o relaxamento, entre outros pontos. Defende, também, o posicionamento "quadrado" da mão esquerda, contrariando as idéias apresentadas por Pleeth.

- Este livro de Gerhard Mantel (Op. cit., 1995) é considerado bibliografia de leitura obrigatória em cursos da grade curricular de Cello (Performance) nas universidades americanas e é tido, informalmente, como uma "bíblia da técnica de violoncelo". Expõe, de maneira metódica, muitos dos tópicos importantes para o aprendizado do violoncelo, sendo um importante guia de reflexão, tanto para instrumentistas quanto para professores.

Destaca aspectos motores usados no dia-a-dia do instrumentista, na técnica propriamente dita, bem como inúmeras partes que integram o "tocar violoncelo", desde o lado emocional do instrumentista, até vibrato, mudanças de posição, pressão, uso do braço direito, entre outras, descrevendo possíveis soluções para possíveis problemas.

- Sobre as aulas de Mstislav Rostropovich, serão apresentados, com a maior fidelidade possível, as idéias e conhecimentos que foram transmitidos a esta autora durante essas quatro aulas, os diversos encontros e conversas, a fim de tornar esse valioso material disponível a outros colegas violoncelistas, perpetuando, através da divulgação dessas idéias, o círculo de generosidade que Mstislav Rostropovich iniciou com esta professora e pesquisadora, lembrando que o conhecimento musical sempre foi transmitido oralmente, e que esse material pode ser tão ou mais útil que o conhecimento obtido por bases bibliográficas. 
1. 1. Victor Sazer e a prática do violoncelo sem dor - Uma leitura de seu livro New Directions in Cello Playing (How to make cello Playing easier and play without pain)

A principal linha de pensamento no livro de Victor Sazer (Op. cit., 1995) é a abordagem da prevenção de dores, desgastes musculares e articulares, e o quê fazer para evitar a tensão ao se tocar o violoncelo, apresentando maneiras ergonômicas de se sentar, fundamentos do uso do arco, do braço esquerdo, como de se posicionar ao instrumento, em busca de uma prática que previna tensões.

As primeiras preocupações pertinentes tratadas por Sazer são: a grande incidência de dores e tendinites ligadas à performance que incidem sobre os violoncelistas e o porquê de haver tanta tensão ao tocar esse instrumento. Por isso, busca, primordialmente, uma maneira de se tocar mais fácil e sem dor, conhecimentos que interessam a qualquer violoncelista, seja professor, iniciante ou violoncelista de domínio técnico mais avançado.

Para o autor, existem alguns princípios que podem conduzir a uma performance com menor esforço e livre de dor. Esses princípios, segundo ele, independem da escola de técnica usada pelo violoncelista e independem, na maior parte das vezes, até mesmo do instrumento a ser tocado. Alguns princípios observáveis nos movimentos do corpo podem ser aplicados a qualquer atividade humana, das mais simples às mais complexas, e, segundo Sazer, qualquer pessoa pode usar esses princípios, o que requer um aprimoramento do autoconhecimento e da percepção dos impulsos naturais do corpo. Assim, declara: “A percepção é a chave. O objetivo é permitir ao corpo agir de maneira natural”.

O livro lida com um fator normalmente negligenciado para um bom aprendizado do violoncelo: o processo de auto-descoberta do corpo, seu equilíbrio, o uso das diferentes partes e do corpo em conjunto, e da respiração, que muitas vezes está em contato direto com o fator emocional do violoncelista. Estudando e aplicando esses princípios com seus alunos, o autor relata ter encontrado algumas alternativas para se aliviar a dor e tornar o ato de tocar mais fácil. Tais hipóteses serão tratadas a seguir.

Os exercícios propostos por Sazer, portanto, estão ligados à percepção dos impulsos naturais do corpo, e são dados por exemplos essencialmente práticos, seguidos 
de perguntas de auto-descoberta e percepção corporal. Após a realização do exercício, e posterior reflexão, podem ser lidas as descobertas e conclusões do próprio autor a respeito deles, de modo a comparar as idéias e, até mesmo, ser surpreendido pela idéia detalhadamente descrita de uma percepção anteriormente apenas sentida.

É um livro prático, desta maneira, ligado ao físico (em sua abordagem, totalmente diferente de métodos de técnica e de estudo tradicionais de violoncelo, se assemelhando muito mais com a abordagem de uma aula prática de técnicas corporais, como Ioga, Meditação ou Técnica de Alexander, por exemplo), com idéias rapidamente aplicáveis de percepção corporal, com o intuito de substituir alguns exercícios de técnica tradicional por essas sensações provocadas, que podem influenciar um aperfeiçoamento mais rápido de alguns aspectos da técnica.

\section{A dor em violoncelistas}

Sobre os músicos e a dor, Sazer narra uma pesquisa publicada na revista americana Health Magazine (maio e junho de 1993), que constata que o percentual de jogadores de futebol americano que sofrem de desgastes físicos e dores (como tendinites e outros problemas) é de $65 \%$, comparado com $75 \%$ dos músicos; dados estarrecedores, em se levando em conta que, por exemplo, tocar um instrumento, nesse caso, o violoncelo, não é um esporte de impacto, nem muito menos são comuns ossos quebrados em sua prática.

Outros estudos descritos mostram que $76 \%$ dos músicos profissionais relatavam sérios problemas médicos que afetavam sua performance e que essa porcentagem é ainda maior entre os músicos de cordas. $\mathrm{O}$ autor afirma que cellistas de todos os níveis e de todas as áreas sofrem de dor, inclusive os artistas mais célebres, e que entre todos os músicos, os cellistas são conhecidos pela mais alta freqüência de problemas de coluna. Sazer diz ainda que muitos músicos ainda relutam em reconhecer esses problemas e ir em busca de soluções, por acharem que assim estarão expondo um lado negro e menos glamuroso do que é ser músico.

Ainda alega que há um arraigado conceito negativo em relação a sanar o problema da dor, que está ligado a uma idéia amplamente corrente de "no pain, no gain", e que faz o imaginário de muitos estudantes aceitar que é necessário sofrer para vir a tocar bem, ou até mesmo se condicionar para não perceber a dor, o que seria, na 
visão do autor, uma idéia errônea, totalmente contraproducente ao sucesso do aprendizado.

Outro destacado estudo descrito por Sazer, feito entre estudantes avançados de música em Houston, em 1988, relata que há maior porcentagem de dor e problemas físicos em cellistas e contrabaixistas do que entre músicos de outros instrumentos.

Victor Sazer afirma que o interesse sobre esse assunto é crescente entre pesquisadores e que existem até mesmo novas especialidades médicas despontando, como a Music Medicine e a Performing Arts Medicine, bem como constata um recente aumento no número de publicações a esse respeito, ligados principalmente à Ergonometria aplicada à Música, sempre com a finalidade de evitar ou sanar problemas físicos, freqüentes nessa profissão.

A primeira hipótese apresentada é a de que as sementes da dor já são plantadas nas nossas primeiras aulas, na construção do início da base técnica. Alguns cellistas, com a prática, deixam movimentos antinaturais tão bem "treinados" que é difícil perceber de onde vem a causa da dor, ou mesmo eliminá-la, enquanto alguns têm maior facilidade intuitiva de usar o corpo mais naturalmente, evitando, dessa forma, graves problemas. O autor afirma que se uma pessoa praticar algo corretamente, o aprenderá corretamente. Se praticar algo de maneira errada, o aprenderá assim também. A prática gera a permanência, não a perfeição ${ }^{1}$.

Essa é uma forte opinião apontada em seu livro, que gera uma reflexão imediata em qualquer estudante de violoncelo consciencioso. Para se evitar esse deslize de compreensão, é necessário um estudo rigorosamente atento, pois qualquer problema de técnica arduamente repetido se instalará, muitas vezes, como um problema de difícil solução, com dores e até mesmo, em casos mais graves, uma impossibilidade de se executar determinados movimentos.

Outra opinião, também compartilhada por muitos terapeutas corporais e professores de educação física, é a de que os movimentos repetitivos podem levar à dor, ainda que não resultem em dor, necessariamente. Os elementos que levam à dor são a maneira, a força e a freqüência dos movimentos, feitas de maneira inadequada.

\footnotetext{
1 "If you practice something right, you learn it right. If you practice something wrong, you learn it that way, too". (...) “Practice doesn't make perfect; practice makes permanent."(1995, p.6 ).
} 
Um dos primeiros aspectos tratados sobre movimentos repetitivos é que a alteração mínima num padrão de repetição de um movimento já propicia um grande e imediato alívio da tensão muscular, na medida em que altera a combinação de músculos envolvidos na execução de determinado movimento. A maioria das causas básicas de danos no corpo tem mais a ver com a maneira como os movimentos são executados do que com a freqüência destes movimentos.

Sazer diz, também, que a grande maioria das dores está relacionada com um pobre equilíbrio do corpo: alinhamento débil, imobilidade e "pressionar" são, para o autor, as maiores causas de ausência de equilíbrio corporal, ou, no termo empregado em inglês, o body balance.

No capítulo três, o autor trata brevemente das partes do corpo mais prejudicadas pelo mau uso dos violoncelistas: as articulações, os músculos, os nervos, os tendões, e a coluna. Serão também acrescentadas, a seguir, as descrições destas estruturas, feitas pelo autor, por se tratarem de uma pertinente introdução ao assunto.

Como descreve o autor, as articulações proporcionam os diversos movimentos e são instrumentos de absorção de impacto; são normalmente prejudicadas quando desalinhadas ou forçadas a se mover além de suas capacidades. Também podem ser prejudicadas pela pressão excessiva.

Os músculos, por sua vez, são fibras elásticas que contraem e relaxam para mover o corpo e todas as suas partes, e são dispostos em grupos que se opõem. $\mathrm{O}$ movimento geralmente ocorre quando um grupo de músculos contrai e outro grupo relaxa. A tensão excessiva acontece quando um grupo que devia relaxar se contrai, e então os dois grupos musculares opostos se contraem simultaneamente.

Assim, usados de maneira errada, podem gerar músculos inflamados ou doloridos, e se esse fato se repete muitas vezes, um tecido ferido, "cicatrizado", como explica Sazer, substitui a fibra muscular normal, e este evento, mesmo quando ocorre de maneira mínima, pode, em seu efeito cumulativo, limitar a flexibilidade permanentemente.

Nervos, por sua vez, são grupos de fibras, dispostas como muitas "cordas unidas", feitas de axônios. Eles formam uma rede que leva as informações do e para o cérebro, e para as outras partes do corpo. Usualmente os danos aos nervos estão ligados à sua compressão seu bloqueio. Sazer diz que o mais conhecido e freqüente dano aos 
nervos, em músicos, é a Síndrome do Túnel Carpal, ou Carpal Tunnel Syndrome (CTS), que está ligada à compressão de nervos que passam pelo pulso, e é comumente gerada por movimentos excessivamente rápidos dos dedos, aliados a um pulso excessivamente inclinado (desalinhado com relação ao braço).

\section{O posicionamento do pulso e as tendinites}

Sazer afirma que, em estudos feitos na Pennsylvania State University, foi constatado que um pulso excessivamente inclinado para baixo é mais perigoso e danoso para os nervos do que o pulso inclinado para cima, ainda que as duas maneiras tragam efeitos prejudiciais.

Os tendões, descritos pelo autor como tecidos fibrosos, conectam os músculos aos ossos. Traumas ou tensões podem causar inflamações ou dor nos tendões, causando as temidas tendinites. Freqüentemente, os tecidos machucados por mais de uma vez estimulam a formação de depósitos de cálcio. Quando isso acontece, de maneira realmente intensa, esses depósitos têm de ser removidos cirurgicamente. Sazer afirma ainda que o prejuízo dos tendões é uma das mais debilitantes enfermidades que podem acometer os músicos.

\section{Sobre a coluna e seu posicionamento em relação ao violoncelo}

A coluna, finalmente, é descrita por Victor Sazer como um complexo sistema de suporte do corpo, composta de 33 vértebras, sendo 24 vértebras superiores separadas por discos de cartilagem, descritas por ele como recheadas de um tecido gelatinoso, que absorvem o impacto dos movimentos destas vértebras. A coluna também contém um cabo de nervos, a chamada espinha dorsal, que transmite os impulsos do e para o cérebro, controlando as atividades abaixo do pescoço: são 31 pares de nervos da espinha dorsal, que transmitem informações entre o cérebro e os músculos, aproximadamente 400 músculos e ainda cerca de 1.000 tendões.

$\mathrm{O}$ autor diz ainda que, habitualmente, os cellistas prejudicam sua coluna por movimentos de torção ou compressão, e que isso pode acarretar rupturas de discos, ou também estressar os músculos das costas e seus tendões. As posições sentadas que deixam o corpo fora de seu equilíbrio e estabilidade são, para ele, a maior causa de dor nas costas. 


\section{Sobre percepção corporal}

Sobre a prevenção da dor, o autor escreve que o corpo está continuamente nos oferecendo informações, ainda que muitas vezes nós as ignoremos ou deixemos de entendê-las, e o primeiro passo para evitar essas dores é a atenção contínua. Outro passo é fazer sempre reavaliações de nossas conviç̧ões básicas sobre o ato de tocar o violoncelo, o que inclui uma cuidadosa revisão de todas as práticas amplamente utilizadas, independentemente da escola de técnica empregada. Por isso, a melhor maneira de melhorar a performance de determinada ação é observar como o corpo reage a ela, em busca de fontes de tensão, com a finalidade de descobrir métodos de tocar evitando-as.

O livro descreve situações de movimentos corporais com e sem o violoncelo, a fim de explorá-los, em exercícios práticos de observação. O autor afirma que, ao desenvolver a atenção sobre a maneira como usamos nosso corpo, nos tornamos mais aptos a nos livrar da tensão indesejada.

Em seguida, Victor Sazer declara que o "teste da respiração" é o melhor diagnóstico de tensão possível: é, para ele, a mais simples e mais eficiente forma de saber se há ou não tensão. Quando o corpo está completamente equilibrado, sem tensão, nós sempre somos capazes de respirar livremente e profundamente. Os nossos corpos estão no pico da eficiência: quando a tensão está presente, nossa respiração é imediatamente restringida.

Para tanto, o autor propõe uma posição equilibrada, em pé: a cabeça alinhada com a coluna, o topo desta apontado para cima, queixo relaxado. Ombros relaxados, peito aberto (sem forçar), a pelve apontando para baixo, os pés alinhados na direção dos ombros, com os dedos levemente voltados para fora. Nessa posição, se executada da maneira correta e livre de tensão, é possível, praticamente, "largar" a parte superior do corpo, acima do quadril, sem que se caia para lado algum. Porém, o autor relata que se algo está fora deste eixo (como por exemplo, a cabeça inclinada para trás ou para qualquer lado, ou os ombros para frente), o corpo não pode ser "largado", ou seja, totalmente relaxado, pois iremos imediatamente tombar.

Essa posição proposta também é possível ao se sentar (imaginando-se a mesma postura, do quadril para cima), que deveria ser a posição correta do violoncelista, 
completando-se pelos pés completamente apoiados no chão, também os dedos levemente voltados para fora, e uma cadeira alta o suficiente para que a parte superior das pernas faça um ângulo de cento e vinte graus em relação à parte inferior das pernas (o que será tratado com maior detalhe posteriormente). Nessa postura correta, deve-se sempre estar atento para que o corpo esteja totalmente relaxado, e que essa postura não seja forçada: ela deve ser, ao contrário, a mais relaxada possível acima dos quadris, e se essa posição estiver totalmente correta, é possível abandonar todo o peso do corpo, nesse eixo, e o corpo não penderá para lado algum.

É possível de se observar que se qualquer parte do corpo não estiver bem equilibrada, nessa postura, o corpo penderá para algum lado, e, contra isso, faremos alguma tensão para nos manter eretos, o que seria errado. A respiração deve ser sempre livre e profunda. Para aumentar essa percepção, Sazer instiga o leitor a fazer, nessa postura, alguma movimentação errada, como por exemplo o tronco levemente torcido para a esquerda (simulando um movimento exagerado para se tocar na corda lá, por exemplo), ou um dos ombros altos, ou até mesmo mantendo a cabeça pensa para trás ou para frente: imediatamente é possível perceber que a respiração se torna difícil, presa.

Entretanto, ao tocar, o tronco jamais está fixo, imóvel, nessa posição ideal: há uma movimentação de arco sobre as cordas, em diferentes ângulos, que faz que o tronco gire levemente de um lado para o outro, e em que é possível perceber a respiração travada nos dois extremos. Sobre isso, Sazer explica que a chave para se manter a respiração livre, ou seja, com o corpo relaxado, não é estar imóvel nessas posições extremas ou na central, e sim manter o corpo sempre em um leve e contínuo movimento. Quanto mais livre e gradual for essa movimentação do corpo, mais livre será a respiração, e mais relaxado ficará o violoncelista.

Outro importante conceito é o de que o corpo humano sempre procura por equilíbrio, como uma balança, na qual se um lado sobe, o outro deve descer, para que haja um equilíbrio de forças. Ele diz que o corpo humano está sempre em movimento. O seu centro de gravidade está constantemente se deslocando, numa série contínua de reações de contrabalanceamentos ${ }^{2}$.

E para o autor, permitir que esse processo de equilíbrio funcione livremente é uma chave fundamental para se tocar violoncelo mais facilmente, aliviando possíveis

\footnotetext{
2 “(...) the human body is always in motion. Its center of gravity is constantly shifting in a series of continuous conter-balancing reactions". (1995, p. 36).
} 
dores. E afirma que quando seu braço do arco e seu corpo se movem em direções opostas, a fricção criada entre o arco e a corda permite que se produza um som facilmente. Se, entretanto, o arco e o braço se moverem na mesma direção, ao mesmo tempo, esta fricção é parcialmente ou completamente neutralizada. Então é necessária uma força maior para produzir o som $^{3}$.

Para o violoncelista, mesmo o mais delicado movimento envolve todo o seu corpo. E diz ainda que, devido ao corpo ser mais pesado que o braço, é também mais poderoso, e, por isso, quando o corpo se move, todo o seu peso é deslocado de um lado para o outro. Para ele, o braço sempre se move na direção oposta à direção do corpo, como por exemplo, quando atiramos uma bola: sempre há um movimento anterior, oposto à direção em que se atirará a bola, para ganhar impulso, força e equilíbrio. $\mathrm{O}$ autor afirma: "Quando seu corpo se move livremente, (...) especialmente quando você o guia com seus pés, você se sente forte e livre de tensão"

Baseado nessa idéia, o autor conta uma curiosa história, que narra um encontro dele com um boxeador. Durante a conversa, o boxeador afirma que muitas pessoas acreditam que os melhores lutadores são os mais fortes. Diz, com entusiasmo, que isso não é verdade, e que tudo é uma questão de equilíbrio e deslocamento de peso. Afirma ainda que nada é mais importante do que o trabalho dos pés. Em seguida, Sazer responde ao boxeador que, ainda que sua profissão como professor de violoncelo pudesse parecer tão diferente da sua, como se poderia imaginar, ele, mesmo assim, ensinava exatamente os mesmos princípios.

Contudo, o autor afirma que a ligação entre o corpo e os pés é mais fácil de perceber quando se está de pé, e que, por conta dessa sensação, provavelmente, muitos violoncelistas (que tocam sentados) não se dão conta das vantagens de se apoiar, e conduzir os movimentos do corpo pelos pés, e que essa prática pode aumentar o conforto e aperfeiçoar o controle dos movimentos corporais. Para reforçar ainda essa afirmação, declara: “Aqueles que focalizam demasiadamente nos pequenos movimentos motores podem facilmente perder essa conexão vital com o resto do corpo" ${ }^{5 "}$

\footnotetext{
3 "When your bow arm and your body move in opposite directions at the same time, the friction created between the bow and string enables you to produce a sound easily. If, however, your bow arm and body move in the same direction at the same time, this friction is partially or completely neutralized. It then takes grater force to produce sound”. (1995, p. 37).

4 "When your body moves freely, however, especially when you steer your body with your feet, you feel strong and free of tension”. (1995, p. 40).

5 "Those who focus too much on small motor movements can easily lose this vital connection with the rest of their body”. (1995, p. 45).
} 


\section{O posicionamento dos dedos, das mãos e a tensão}

Sazer declara que mesmo quando fazemos apenas uma pequena pressão dos dedos no arco, por exemplo, podemos sentir essa tensão irradiando por todo o braço, e quando pressionamos mais forte, sentimos essa tensão se estender também para a região das costas e coluna.

E descreve que empurrar é semelhante ao ato de pressionar, por ser uma ação semelhante que se move em diferente direção. Diz ainda que os atos de "pressionar" e “empurrar" comprimem as juntas. Conclui em seguida que "levantar" (ou erguer) e “puxar", são similarmente relacionados, contudo esses movimentos têm efeitos opostos aos de "pressionar" e "empurrar", pois minimizam a tensão e reduzem os perigos de danos.

Baseado nessas conclusões, o autor diz ainda que muitos violoncelistas acreditam que devem pressionar para tocar seus instrumentos. Alguns ainda entendem que pressionar causa realmente a tensão, mas vêem esse fato como um mal necessário. "Mal, sim, mas necessário, não!"”.

\section{O $\operatorname{arco}$}

Sazer lembra que mais esforço é necessário ao se tocar na ponta do arco do que no talão. Ou seja, usando o peso do braço para dar pressão, o equilíbrio deve ser constantemente reajustado em cada região do arco. Puxar, segundo o autor, requer o mesmo esforço em qualquer parte do arco, permitindo um contato consistente do arco na corda, e elimina o ajuste de peso ou pressão. Ou seja, o movimento que deve ser imaginado é horizontal, e não vertical. E conta uma frase de um de seus colegas: " $A s$ more you presses, as less you getses!" (sic); ou seja, quanto mais pressão, menores os ganhos.

Com essas idéias, o autor conclui que qualquer coisa que se faz pressionando ou empurrando, pode ser feita puxando ou levantando (ou erguendo).

\footnotetext{
6 “Evil, yes; necessary, no!” (1995, p. 47).
} 


\section{O sentar-se ao violoncelo}

Em relação ao ato de se sentar, o autor dedica um capítulo, posto que é ação tão importante para o músico, especialmente para o violoncelista, que só é capaz de desempenhar sua função sentado, permanecendo nessa posição muitas horas por dia. Declara que a taxa de dores nas costas em violoncelistas é maior do que em qualquer outro grupo de músicos, e que a maior causa dessas dores está relacionada a um "sentarse" inadequado.

E propõe uma idéia que difere muito do pensamento usual, ensinado nas aulas de violoncelo, citando um estudo do Dr. Richard Norris, em seu livro The Musician's Survival Manual, que afirma que o corpo humano não foi desenhado para se sentar com as costas e a parte superior da perna em um ângulo de $90^{\circ}$, pois os ossos do quadril só podem se mover livremente quando o tronco e as pernas estão num ângulo aproximado de $15^{\circ}$ a $20^{\circ}$ maior que isso, ou seja, de $105^{\circ}$ a $110^{\circ}$.

Um ângulo menor do que isso, segundo Norris, causa um rotação da pélvis para trás, e esse movimento reverte a curva lombar, deixa o diafragma flácido, e pressiona o peito, impedindo uma livre respiração. Nessa posição, o centro de gravidade do corpo se desloca para trás dos ossos sobre os quais nos sentamos, e uma força muscular considerável é necessária para se sentar.

Qualquer aluno de violoncelo mais avançado, ou violoncelista profissional, já ouviu de algum professor (ou até mesmo ensina desta maneira) que o ângulo correto para se sentar seria ter $90^{\circ}$ das costas em relação à parte superior da perna, $90^{\circ}$ entre a parte superior da perna e a parte inferior, e outros $90^{\circ}$ entre a parte inferior da perna e os pés. Essa afirmação do Dr. Norris, citada por Sazer, contesta essa arraigada idéia, com argumentos médicos.

Sobre isso, Sazer também afirma que, sentado neste novo ângulo, o violoncelista não sente desconforto lombar e pode respirar livremente. Por isso é tão importante encontrar uma cadeira adequada que proporcione essa altura e esse ângulo, e, em geral, essa cadeira deve ter o assento mais alto do que nos modelos usados usualmente. Normalmente, os violoncelistas altos, ou de pernas compridas, têm mais dificuldade de encontrar tais cadeiras, especialmente em locais de trabalho, como ensaios de orquestras ou escolas de música. 
Para resolver esse problema, o mais adequado seria usar cadeiras de alturas ajustáveis, como, por exemplo, alguns modelos de bancos de piano, ou então, se não for possível levar aos ensaios a própria cadeira adaptada a essa condição, levar uma almofada que proporcione estar com as coxas nesse ângulo aproximado de $120^{\circ} \mathrm{em}$ relação às costas. Em casa, seria possível colocar pedaços de madeira adaptados aos pés traseiros da cadeira, ou qualquer outra adaptação que proporcione um ângulo maior, o que imediatamente tornaria o ato de tocar mais agradável e menos sofrido, e, em longo prazo, com menos chances de uma possível lesão lombar.

\section{A importância dos pés}

Sazer também aborda o posicionamento dos pés. $O$ autor declara que, normalmente, um erro feito por muitos violoncelistas é deixar os pés num alinhamento atrás da linha dos joelhos, e que esta postura imediatamente faz o corpo (o tronco e quadris) inclinar para frente, fazendo o músico sair de seu eixo natural de equilíbrio. Isso também ocasiona uma maior pressão no peito do violoncelista em seu instrumento. $\mathrm{O}$ correto para o autor seria posicionar os pés levemente à frente da linha dos joelhos, o que ajuda, segundo ele, a dar uma sensação de equilíbrio natural, e aumenta a percepção do uso dos pés, ou seja, do contato com o chão.

Também afirma que ampliando a distância entre os pés (ou seja, abrindo mais as pernas, em especial a perna direita, que não precisa estar, necessariamente, em contato com o violoncelo) é ampliada substancialmente a sensação de conforto ao tocar. Sazer diz, ainda, que este posicionamento mais aberto auxilia um maior suporte dos golpes de arco pelas pernas. E questiona: "Você consegue imaginar qualquer outra atividade em que você continuamente leva seu braço para longe de seu corpo e na qual você não tente suportar esses movimentos reajustando suas pernas? Ainda assim, essa prática é quase universal entre os violoncelistas ${ }^{7 \%}$.

\section{Posicionamento do violoncelo em relação ao corpo do instrumentista}

Uma importante idéia sobre técnica, abordada por Sazer, é o posicionamento do violoncelo em relação ao corpo do violoncelista. $\mathrm{O}$ autor declara que um dos

\footnotetext{
7 "Can you think of any other activity in which you would continually reach your arm away from your body and not try to support it by readjusting your legs? Yet this is an almost universal practice among cellists." (1995, p. 67).
} 
posicionamentos mais empregados, que é o violoncelo centralizado no meio do corpo, levemente inclinado, para permitir que o braço do instrumento esteja mais à esquerda do pescoço, com as duas pernas encostadas nas laterais do instrumento, é um dos menos confortáveis, em termos de desempenho, ao tocar.

Ele acredita que essa idéia provoca excessiva movimentação do corpo e que obriga torções do tronco, para que se alcance tanto a corda dó quanto a corda lá, principalmente quando se está usando a ponta ou parte superior do arco. Ou seja, o violoncelista precisa fazer, constantemente, ajustes de torção do corpo para poder tocar nessa posição, o que seria prejudicial à coluna.

A posição proposta por Sazer é a do instrumento deslocado mais para o lado esquerdo do corpo do violoncelista; nesse caso, o instrumento estaria apoiado em três pontos, que seriam o peito (lado esquerdo) do instrumentista (pouco abaixo das mamas, ou mamilos), a perna esquerda e o espigão. Nessa posição, o violoncelista não precisa manter contato da perna direita na lateral do instrumento.

Para Sazer, a posição deslocada para a esquerda permite uma amplitude muito maior de movimentos do instrumentista com seu arco (o alcance do braço é ampliado), e a movimentação do braço direito é imediatamente mais livre. Porém, o ponto fundamental de vantagem levantado pelo autor é que nessa posição não é necessário que se movimente o corpo, em uma torção lateral (que não é acompanhada pelo quadril, pois, por estar sentado, este não pode se movimentar, naturalmente, nesse mesmo sentido), para alcance de cordas lá e dó. Não é necessário, também, um esforço extra para se atingir a ponta, nem mesmo um deslocamento do cotovelo para trás da linha do corpo, movimento que ocorre no outro posicionamento proposto, principalmente ao se tocar a corda dó, na região superior do arco.

O autor afirma que Jean Louis Duport (1749-1819) já usava essa posição, considerada pelo autor uma posição mais adequada ao violoncelo moderno, o que é mostrado, em seu livro, em um retrato de Duport, reproduzido no livro de Dimitry Markevitch. Duport, violoncelista virtuoso e grande professor, já nessa época pregava esse posicionamento, enquanto que a maneira mais antiga (barroca) posicionava o violoncelo mais ao centro do corpo, como mostram inúmeras pinturas antigas. Sazer declara ainda que essa posição liberta mais o corpo, e que, embora já seja usada há tanto tempo, desde Duport, hoje ainda é prática comum que se ensine o posicionamento 
centralizado (segundo ele, é a prática mais comum), ainda que mais desconfortável em tantos aspectos, e especialmente prejudicial para pessoas pequenas ou de braços curtos.

Reforçando a idéia, o autor acredita que o melhor posicionamento do violoncelo é ao lado esquerdo do corpo, com a perna direita realmente bem afastada do instrumento. Segundo ele, nessa posição, o corpo fica balanceado e flexível, e todos os movimentos, ao tocar, têm suporte completo. Assim, é possível alcançar todas as regiões do cello, sem tombar, se torcer ou se inclinar para frente, e se sentir como se estivesse "quase em pé ${ }^{8}$. Além disso, Sazer afirma que esta posição facilita o deslocamento mais livre da mão esquerda (e do braço esquerdo), tanto nos movimentos dos dedos, que ficam mais livres do que se estivessem encostados, ou muito próximos ao pescoço ou queixo, quanto no deslocamento do braço, no movimento de cima para baixo, em mudanças de posição, por exemplo, pois se encontra mais afastado do corpo.

\section{Ombros}

Victor Sazer recomenda que o violoncelista esteja sempre atento para manter os ombros atrás do violoncelo, independentemente do posicionamento escolhido.

\section{Movimentos circulares}

Outra pertinente idéia apontada pelo autor é a de que não existem movimentos retos, como se costuma pensar, ao se produzir o movimento de arcadas, com o "sobe e desce", ou "talão, ponta, talão", ou "ida e volta", como se costuma dizer. O movimento do arco é sempre feito em diversas curvas, que levam todo o corpo a se movimentar também em curvas. E cita Leonard Rose: "There are no straight bows", ou seja, "não existem arcos retos", conforme se pode facilmente pensar que existam.

Numa música, na maior parte das vezes, mudamos também de cordas, em meio ao movimento de "vai e vem" das arcadas, o que ocasiona vários e sutis movimentos circulares, facilmente vistos se nos fixarmos, por exemplo, no botão do arco. E mesmo num arco aparentemente reto, existe (ou deveria existir), uma movimentação em forma de "oito deitado" nas mudanças de direção de arco, ou seja, o símbolo do infinito, que é indispensável, segundo o autor, para que o som se mantenha constante, pois melhora o efeito de aderência da crina na corda.

\footnotetext{
8 "You can access all regions of your cello without slouching, twisting or leaning forward. You may feel as if you are semi-standing when you sit this way". (1995, p. 79)
} 
Os movimentos circulares do arco, principalmente ao se principiar uma arcada, devem ser iniciados, muitas vezes, até mesmo antes que o arco atinja a corda, para que o braço e o arco ganhem impulso, e estejam em movimento antes mesmo do roçar da corda, a fim de tornar o ataque da nota menos perceptível e mais contínuo; este movimento deve estar ligado ao impulso da respiração, mais especificamente o da inspiração, e o arco deve chegar à corda com um movimento semelhante ao de um avião pousando, nesse tipo de circunstância.

\section{Posicionamento dos dedos}

Em relação ao posicionamento dos dedos, Sazer afirma que a muitos alunos thes é ensinado que devem separar seus dedos uns dos outros, sempre os posicionando como se estivessem prontos para tocar uma nota (como "sobrevoando-as"), e lembra que, aos iniciantes, é ensinada a distância das notas, muitas vezes, por meio de fitas adesivas, em cima das quais os dedos deveriam sempre se posicionar.

Esse autor concebe que isso traz mais danos do que benefícios, pois treina os estudantes a "segurar" o distanciamento de seus dedos de maneira tensa (pois a abertura da mão torna-se maior do que a da mão relaxada), além de ensiná-los a procurar as notas por meio de sinais errôneos: são ensinados a senti-las por meio das fitas adesivas, em vez de serem ensinados a confiar em seus corpos e seus ouvidos. Ele afirma ainda que esse tipo de método de ensino torna muito difícil evitar a tensão.

\section{Tocar devagar $\mathbf{x}$ tocar rápido}

Uma idéia muito útil tratada em seu livro é a que a técnica empregada para se tocar lentamente não é a mesma da técnica usada para se tocar rapidamente. $\mathrm{O}$ autor compara a técnica da caminhada com a da corrida, afirmando que correr não é a mesma coisa que andar rapidamente. Cada uma das duas maneiras de tocar usa um diferente alinhamento do corpo, principalmente do braço esquerdo e mão esquerda.

Declara que, para se tocar rapidamente, a mão esquerda deve estar o mais livre de tensão possível, em uma posição de braço bem colocada, na posição mais intermediária das mudanças a serem realizadas, ou seja, a mais neutra possível. Os dedos devem estar, ainda, um pouco mais curvados (arredondados) ao se tocar rápido, 
pois isso equaliza um pouco o tamanho dos dedos, e quanto mais homogêneo o movimento, mais homogêneas são as mudanças dos dedos, no que diz respeito ao ritmo.

Já o tocar lentamente permite tempo suficiente para ajustes do braço e da mão esquerda, o que otimiza um melhor alinhamento para cada nota, ou grupo de notas.

\section{Mudanças de posição}

Em relação às mudanças de posição, Sazer diz que embora os impulsos preparatórios do corpo possam estar na direção das mudanças, o corpo se move na direção oposta nesse momento (ou deveria se mover). Apoiar esses movimentos inversos com os pés pode ser de grande ajuda para manter um bom equilíbrio corporal. Ainda afirma que a parte superior do braço deve se mover anteriormente à parte inferior do braço, para dar maior suporte ao movimento.

\section{O polegar da mão esquerda}

Sazer recomenda que, sempre que possível, se libere o polegar, pois isso traz um retorno imediato de indescritível liberdade.

\section{Conselhos finais}

Finalmente, o autor dá conselhos sobre como usar melhor o corpo ao tocar: ter um tratamento adequado com o próprio corpo, pois se ignorarmos os sinais do corpo ou os impulsos naturais, este nos responderá com machucados e dores. Sugere "erguer o corpo", ou seja, mantê-lo sempre bem posicionado e ereto, para que ele possa respirar livremente, além de evitar sempre quaisquer movimentos de pressão.

Aconselha também que se deixe todas as partes do corpo trabalharem "socialmente", pois dessa forma são mais "felizes", como músicos de um "ensemble". E que se use sempre mais as partes grandes do corpo, ao invés das pequenas, a fim de ajudá-las, além de nunca separar os dedos desnecessariamente.

Sazer conta ainda uma lição recebida de seu primeiro professor (Charles Brennand), que alertava para que cada violoncelista sempre fizesse uma reflexão individual sobre o violoncelo, e que também sempre estivesse aberto a mudanças de opinião, o que ele simbolizava como escrever sempre a lápis, nunca a caneta, pois é possível sempre que se venha a ter uma idéia melhor. 
Sazer reforça ainda, novamente, a idéia de que se deve sempre pensar no movimento corporal em linhas curvas, nunca em movimentos quadrados ou retos. 


\title{
1. 2. Paul Tortelier, o polegar e a resolução de problemas práticos de técnica - Uma
} leitura de seu livro El Violonchelo, así interpreto, así enseño

\author{
"Émethor ser beto do que serbom. \\ Masé melhor ser bom do que ser feio". \\ OSCAR WILDE
}

\section{Caráter e gentileza}

No prefácio de seu livro (Op. cit., 1993), Paul Tortelier cita uma afirmação, feita por Pablo Casals, que diz que na vida é preciso mostrar caráter e gentileza. Tortelier acrescenta que a aplicação desse equilíbrio filosófico, no plano físico, é o que caracteriza as boas escolas de interpretação violoncelística, pois para mostrar caráter e gentileza, a mão do violoncelista deve ser forte, sem ser pesada; firme, mas não rígida, flexível, mas nunca frouxa (...).

$\mathrm{O}$ autor aponta que nenhuma dessas qualidades surge comodamente, nem ao menos nas pessoas de maior talento, sendo um erro, portanto, confiar na própria facilidade natural para se alcançar um controle perfeito. Diz que ninguém deve ser complacente, em nenhum caso, nos primeiros anos de estudo, e que não se deve deixar de praticar em nenhum nível.

Tortelier afirma que, embora o violoncelo tenha uma postura de interpretação que parece mais natural do que a do violinista, a técnica se baseia em um equilíbrio talvez diferente do que tem o violino, mas nem por isso menos delicado. Diz também que, no caso do violoncelo, a afinação exige uma atenção constante.

\section{A luta do violoncelista}

Para conseguir todo o equilíbrio que geraria o máximo de segurança possível, para se alcançar a precisão de que a música necessita, a fim de produzir todos os sentimentos que ela expressa, deve-se lutar contra as debilidades naturais constantemente e desde o princípio, segundo o autor. Lembra também que a mão é 
composta de dedos de tamanhos e forças desiguais, e isso já se apresenta como uma debilidade física a ser combatida. Contudo diz que a disciplina que deve ser empregada para combater essas debilidades não pode ser de uma rotina insípida, mas uma demonstração de imaginação e flexibilidade correspondentes ao artista.

Tortelier critica o modo, dito por ele "empírico", de se ensinar a agarrar o arco com quase todo o punho, e critica também o hábito de liberar o polegar do braço do instrumento para facilitar a realização do vibrato, o que, para ele, deveria ser prática proibida a jovens violoncelistas menores de dezoito anos, não estendendo essa idéia posteriormente.

\section{O ensino do som}

Em seguida, Tortelier afirma lamentar observar tantos violoncelistas que poderiam ter sido muito mais felizes artisticamente se lhes tivesse sido oferecido um ensino do som, desde o princípio. Acredita que os defeitos desenvolvidos num primeiro ano de estudo são difíceis de corrigir, sendo esse livro, por ele escrito, um trabalho para ajudar aos professores de violoncelo a lidar com principiantes (ou, bem entendido, com o princípio da técnica e da prática).

\section{Os polegares}

Esse livro traz alguns aspectos, não usuais, tratados pelo autor como pontos fundamentais da técnica básica, como, por exemplo, a importância marcante dos polegares e as regras a que se encontram sujeitos. Polegares que, segundo Tortelier, desempenham, secretamente, um papel essencial a toda a técnica de execução do violoncelo; papel que, segundo ele, não foi muito fixado por outros autores e professores até então.

Uma abordagem, provavelmente inédita até aquele momento (e esse ineditismo é apontado por Tortelier) é colocada sobre o papel do polegar da mão esquerda: semelhante aos movimentos aplicados pelos pianistas com seus polegares, e denominado, por ele, de a técnica do "passo do polegar pianístico", que consiste, resumidamente falando, num posicionamento específico deste polegar, tanto em posições fixas (em que permanece de frente para o segundo dedo, porém atrás do braço do instrumento), como em extensões (continuando atrás do braço do violoncelo, de 
frente para o segundo dedo, muitas vezes, tendo que, para isso, se movimentar muito mais do que da maneira habitual), bem como um deslocamento do polegar esquerdo prévio às mudanças de posição da mão.

Neste misto de método de exercícios práticos de técnica e livro a respeito da mesma, Tortelier propõe vários exercícios de técnicas de sautillé, spicatto, controle de arco, posicionamento do cotovelo, uso do pulso coordenado com o cotovelo, variações rítmicas para o uso do arco, aderência na corda, dinâmicas, respiração, entre muitos outros tópicos sobre a técnica violoncelista, apresentando e defendendo sempre suas idéias e experiências pessoais, com grande meticulosidade de informações.

\section{O valor da técnica}

Para se estudar seu método e os exercícios propostos, Tortelier aconselha fazê-lo com o máximo de paciência e profundidade possíveis, sempre invocando um sentido musical destes. Afirma também que o valor de uma técnica não se julga somente pela interpretação eclética e pela perfeição da execução, mas também por um ótimo resultado obtido com o mínimo de esforço. E acrescenta que se, uma vez alcançado um controle perfeito, o instrumentista consegue também mantê-lo com o passar dos anos sem a necessidade de muitas horas de prática, então poderá estar seguro da firmeza dos princípios nos quais sua técnica está baseada.

Em relação às bases de posicionamento do violoncelo e do arco, Tortelier apresenta as várias idéias enumeradas em seguida.

\section{Posição do instrumento em relação ao violoncelo}

Sobre a altura da cadeira, o autor diz que esta deve ser posicionada segundo o tamanho das pernas do executante. Os pés devem estar bem separados, com as plantas dos pés apoiadas no solo. $\mathrm{O}$ assento da cadeira, para Paul Tortelier, deve ser plano, sem encosto, e é melhor mais firme que macio.

Em relação ao espigão, assim como a altura da cadeira, devem ser proporcionais à altura do violoncelista, e, para Tortelier, deve ser tão grande quanto o permita a altura desse instrumentista. $\mathrm{O}$ espigão deve se situar ligeiramente à esquerda do executante, permitindo que o violoncelo se posicione, também, ligeiramente à esquerda do corpo do cellista. Com isso, a lateral do instrumento deve encostar-se no joelho esquerdo, e o 
violoncelo posicionado, totalmente, com seu tampo voltado para frente, e não levemente à diagonal, como se posicionaria se o violoncelo fosse colocado bem no centro do instrumentista.

A cabeça e os ombros, para o autor, devem ser posicionados retos, ou levemente inclinados para frente, mesmo quando se esteja usando o espigão torto, chamado “Tortelier". Alerta para que, quando se toque em posições mais altas (agudas), deve-se acentuar a inclinação da cabeça para frente.

O autor condena também ombros levantados, cotovelos excessivamente levantados, além do pulso direito muito abaixado, assim como condena o outro extremo, que seria composto de cotovelos demasiado baixos e pulso muito alto. Para ele, ombro, braço e mão devem formar uma linha não "quebrada": o cotovelo deve seguir sempre o que chama de "a linha natural do braço", sem explicá-la.

Em algumas circunstâncias, Tortelier acredita que o instrumentista de braços curtos terá que adiantar seus ombros para frente, além de, em alguns casos, adiantar também seu torso. Pelo contrário, se esse instrumentista tiver braços muito longos, deverá posicionar seu ombro mais para trás, sobretudo quando toque próximo do talão do arco nas cordas graves, a fim de evitar que o cotovelo fique excessivamente dobrado e fechado.

\section{O arco e o posicionamento da mão direita}

Tratando da maneira de se segurar o arco, Tortelier propõe que o polegar deve estar curvado e colocado de maneira que a ponta direita da polpa do dedo (lateral direita do polegar direito, no olhar do próprio violoncelista) fique em contato com a esquina do que ele chama de "noz" do talão, e a unha em contato com a vara de madeira do arco. O dedo médio deve ter a metade de sua parte extrema sobre o aro de metal, e a outra metade sobre as crinas. Aconselha que o violoncelista estenda a primeira articulação de maneira que sinta não só o arco metálico ou as cerdas, mas também a vara do arco, que deve se apoiar, aproximadamente, na curva da primeira articulação.

Já o dedo indicador, para Tortelier, deve ser colocado de maneira claramente vertical sobre a vara, justamente em cima da primeira curva da primeira articulação. A vara do arco pode também ser empurrada um pouco mais para dentro, entre a primeira e a segunda articulação, para conseguir mais potência sonora. 
O terceiro dedo deve ser esticado de maneira que se apóie contra o que ele chama de "noz" do arco (chamada de talão, por muitos), sentindo a totalidade de sua forma côncava. Já o dedo mínimo, ou quarto dedo (em se tratando da numeração empregada pelos instrumentistas de cordas aos dedos da mão esquerda, quais sejam 1-2-3-4, excluindo o polegar ou chamando-o de 0), deve ser situado justamente em cima do círculo metálico (às vezes também feito em osso, madrepérola ou outros materiais ${ }^{9}$ ) do talão.

\section{Sensação de pousar a mão sobre o arco}

Sobre a maneira de se segurar o arco, Tortelier afirma que, em geral, se comete o erro de fazer que o principiante "agarre" o arco, para sustentá-lo, quando, em realidade, somente deveria "pousar" sua mão sobre ele, com a forma adequada. Com a finalidade de provocar e obter essa sensação, ele propõe um exercício: pede que se sustente o arco com a mão esquerda, e que o coloque sobre a corda ré, com a crina totalmente apoiada, de maneira plana, sobre a corda. Em seguida, que se deixe o braço direito relaxado e pendurado, ao longo do corpo.

Depois, o aluno deve suspender a mão direita sobre o talão, e, deixando o polegar no ar, deslizar a mão, baixando-a lentamente, até que o primeiro e o quarto dedo cheguem a seus pontos de contato, anteriormente propostos. Mantendo, ainda, o polegar solto do arco, pede que se cheguem os dedos centrais às posições descritas. Nesse ponto, ainda segurando o arco com a mão esquerda, sugere que se puxe o arco para si, curvando somente as segundas articulações dos dedos. Deve ir e voltar, repetindo essa ação várias vezes, a fim de sentir o contato desses quatro dedos no arco. Tortelier afirma que, se essa ação for feita corretamente, produzirá um som parecido ao de um arranhar na corda, além de colocar todos esses dedos em contato adequado com o arco.

Esta, então, seria a hora de se posicionar o polegar corretamente, como já foi descrito. Logo a seguir, deve-se tirar a mão esquerda e fazer imediatamente o primeiro golpe de arco, para baixo (ou seja, do talão para a ponta), até dois terços de sua longitude total.

Esse exercício, na opinião desta pesquisadora, é recomendado para aumentar a sensibilidade da mão direita em relação ao arco, aumentar a percepção desses

\footnotetext{
${ }^{9}$ Nota desta pesquisadora.
} 
movimentos e até mesmo corrigi-los, não somente para iniciantes, mas sempre que se quiser aumentar esse grau de intimidade do violoncelista com seu arco, em qualquer estágio de desenvolvimento de sua técnica.

\section{Percepção do polegar no arco}

Para aumentar a percepção da mão no arco, principalmente a do polegar, o autor propõe outro exercício simples, que pede que o violoncelista posicione suas mãos uma contra a outra, palma com palma, dedos com dedos, como para rezar ou fazer uma reverência. Aos poucos, pede-se que vá se curvando os dedos, lentamente. Pouco a pouco, é possível notar claramente como os dedos e polegares se posicionam naturalmente na posição desejada, que se coloca no arco; é especialmente útil, nesse exercício, notar a posição curva e relaxada, totalmente natural, a que chega o polegar, e que é a posição ideal a ser usada no arco.

Esta pesquisadora acredita que esse exercício é tão simples quanto revelador, e que pode ser especialmente útil para o ensino de um iniciante, que tem, muitas vezes, pouca noção de percepção corporal, principalmente das mãos, e muito acentuada a sensação de que segurar o arco é algo difícil. É extremamente fácil ver a curvatura correta do polegar nesse exercício, principalmente se o aluno curvar seus dedos deixando, mais ou menos uma distância de um a dois centímetros da ponta do indicador ao polegar: esta já seria a postura da mão toda, proposta por Paul Tortelier.

\section{O primeiro dedo na mão direita}

Para assegurar que, nessa posição, o primeiro dedo esteja totalmente livre para se movimentar, Tortelier indica um exercício: com o arco na corda e a mão direita posicionada "corretamente", conforme suas instruções anteriores, o cellista golpeie o arco com o indicador, várias vezes, de modo semelhante a um fumante que bate as cinzas de seu cigarro, a fim de liberar os movimentos desse dedo.

\section{O pulso e a arcada para cima}

Para se demonstrar os movimentos do pulso, na execução de um arco para cima (da ponta para o talão), Tortelier propõe um exercício de percepção: pede que se desenhe um pequeno círculo na articulação esquerda do pulso direito, e que se posicione 
o dedo indicador da esquerda, apontado para este círculo, a uns $2,5 \mathrm{~cm}$ do círculo. A ponta dos dedos deve estar apoiada em uma superfície plana, como uma mesa. Em seguida, pede que se leve o pulso, até o que o dedo indicador da mão esquerda encoste nesse círculo. Pede que se repita esse movimento várias vezes, sem que se tire a ponta dos dedos da superfície plana, e que se constate que esse movimento é o mesmo executado em um arco "para cima".

Em seguida, o autor pede que se aplique esse mesmo movimento com o arco na corda, contudo, posicionando esse arco na sua região central, onde deve estar colocada a mão esquerda, para apoiá-lo e segurá-lo, como foi já foi feito em exercício anterior. Diz para que se repita o movimento, ainda segurando com a esquerda, até obter a sensação do exercício corretamente executado, como na mesa, e só então retirar a mão esquerda. Recomenda, contudo, que não se esqueça de manter relaxado o braço direito.

Paul Tortelier afirma que a execução do arco "para cima" é iniciada pelo pulso, não pela mão, ainda que golpes curtos de arco para cima sejam iniciados pela mão.

\section{Polegar da mão direita}

Em relação ao polegar da mão direita, Tortelier afirma não só sua importância, mas sua responsabilidade pelo posicionamento da mão e do cotovelo, recomendando que este polegar deve estar sempre curvado, no arco "para cima", exceto ao chegar ao talão, e que, durante as mudanças de direção do arco, deve estar sempre flexível e manter uma ação elástica e lateral, no que diz respeito à primeira articulação. Alega também que ele deve ter um contato muito pequeno com a "esquina" do talão.

$\mathrm{O}$ autor afirma que o dedo indicador suportará um mau posicionamento do polegar, "enganchando-o" ao arco, e multiplicando os problemas em rigidez da mão, pouca crina na corda, pulso ou cotovelos demasiado altos, entre outras tensões desnecessárias.

\section{A mão direita}

O autor acredita que o posicionamento correto e flexível da mão permite que o violoncelista se expresse com delicadeza, firmeza, destreza, leviandade, energia e romantismo, conforme o que seja necessário, e que também permite transferir o peso natural de todo o braço, de forma completa, por toda a mão. Acredita também que o 
dedo mínimo, em "contra-ação" com o dedo indicador, seja de extrema importância para todo o caminhar e equilíbrio do arco, principalmente na execução das inúmeras sutilezas de mudanças de dinâmicas.

Outro exercício proposto pede que se coloque uma moeda no dorso da mão direita, quando esteja bem posicionada, ao se fazer arcadas para cima e para baixo, para que se mantenha o mesmo nível de posicionamento durante toda a trajetória do arco.

\section{O braço esquerdo}

Falando do lado esquerdo, Tortelier acredita que o braço nunca deve tocar o corpo, nem mesmo em sua posição mais baixa e relaxada. Ele acredita que existem níveis de alturas do braço, um para cada corda, mesmo nas mudanças de posição, com exceção da corda lá, em que pensa haver dois níveis, um para as posições mais graves (com o cotovelo e o braço mais baixos), em que defende ajudar nas passagens lentas e no vibrato, e outro nível para as posições mais agudas.

Pensa também que o cotovelo deve estar sempre móvel e ágil, cooperando com a mão, em vez de atrapalhá-la. O antebraço, para o autor, deve manter-se perpendicular à corda, e que em todas as posições e cordas, deve-se formar uma linha não quebrada entre o cotovelo e a mão.

Paul Tortelier defende que o pulso deve estar sempre firme, especialmente durante as mudanças de corda e posições, e também no vibrato. Acredita, também, que, em passagens mais lentas, pode-se colocar o pulso mais baixo, mas adverte que isso deve ser feito sempre junto com o braço, pois esse movimento permite tocar mais com a carne da ponta dos dedos (auxiliando em um vibrato mais "gordo" e amplo ${ }^{10}$ ).

\section{O polegar esquerdo}

A idéia mais marcante do livro de Paul Tortelier, no entanto, é a da importância do polegar esquerdo, e a convergência dessa importância em toda a sua técnica do violoncelo: o autor acredita que, entre todos os dedos da mão esquerda, o principal responsável por uma boa postura, um correto relaxamento, agilidade e leveza da mão esquerda, e, principalmente, pela afinação é o polegar.

\footnotetext{
$\overline{{ }^{10} \text { Nota desta pesquisadora. }}$
} 
É útil acrescentar, por parte desta pesquisadora, que essa opinião descrita acima, ainda que seja indiscutivelmente racional e elucidativa sobre o pensamento do autor, é bastante incomum. Foi feita uma enquete informal, entre colegas violoncelistas e durante as aulas de quinze alunos desta pesquisadora, a respeito de qual seria o dedo da mão esquerda mais responsável pela boa afinação, posição correta, relaxamento e firmeza da mão esquerda. É curioso expor que absolutamente nenhum dos alunos e colegas questionados tenha respondido que seria "o polegar", nem mesmo, posteriormente às suas respostas, sendo induzidos a dizê-lo, com algumas "dicas" das explicações de Tortelier, que fosse "o polegar" o dedo mais importante. Essa informação, mesmo não sendo uma amostragem válida estatisticamente, apresenta indícios do ineditismo e da inovação que essa idéia vem trazer.

Com base nessa afirmação, Tortelier explica que a mão esquerda deve estar sempre arredondada, com o polegar posicionando-se atrás do segundo dedo (dedo médio), sempre formando um arco perfeito (até a $4^{\mathrm{a}}$. posição), atrás do braço do instrumento. Sua função, nesse caso, é reforçar a força central da mão, controlando a afinação e prestando ajuda ao terceiro e ao quarto dedo, que são menos desenvolvidos e ágeis. A posição do polegar deve ser similar à do polegar da mão direita, anteriormente descrita, utilizando sua borda superior, junto à unha, para roçar o braço do violoncelo.

Propõe, para que se sinta melhor o polegar móvel e livre, que se golpeie o braço do instrumento com o polegar esquerdo, e até que se raspe o braço do cello com o mesmo, aumentando sua sensação de posicionamento e mobilidade, sempre movimentando a primeira articulação. Propõe também que se exercite, ao tocar, por exemplo, o segundo e o terceiro dedos em posição de primeira posição, que se coloque o polegar em capotasto, em meia posição, a fim de movimentá-lo para o local do primeiro dedo da primeira, entre outros exercícios similares, com a finalidade de movimentar o polegar, em sua primeira articulação, na frente do espelho; movimento que deverá ser executado, posteriormente, atrás do braço do cello.

Essa movimentação do polegar, que será silenciosa atrás do braço do cello, deverá acompanhar o segundo dedo, sempre que este se movimentar, seja de notas, cordas ou posição, como se estivesse tocando a mesma nota correspondente, porém sem som. Com a percepção desse "tocar silencioso", gradualmente o polegar deve ir adquirindo precisão e assegurará uma afinação eficaz, segundo Tortelier acredita. 
O autor chama também a atenção para que este mesmo polegar (quando posicionado atrás do braço do cello) também se movimente em ângulos diferentes, nas mudanças de cordas, acompanhando os movimentos proporcionais de pulso e cotovelos, rodando para o sentido inverso da corda que se deseja atingir, ou seja, para o lado da corda dó ao se tocar a corda lá, por exemplo, ou na direção da corda lá, ao se tocar a corda dó; ou seja, sempre em sentido de rotação inversa, contudo, sem deixar de se manter atrás do segundo dedo.

Tortelier atenta para a diferença entre a primeira, segunda e terceira posições, em relação à quarta posição. Nessa posição, devido ao corpo do violoncelo, é necessário que se posicione o polegar sempre atrás do primeiro dedo, para manter a mesma relação de afinação, destreza e força. Ou seja, na quarta posição, o polegar deve estar atrás do primeiro dedo.

Assim, em quinta, sexta e sétima posição, o polegar precisa ser posicionado no mesmo lugar em que se posicionaria se estivesse na quarta posição, embora o resto da mão se desloque para as posições mais agudas e o polegar possa estender as suas articulações.

\section{Sobre a prática}

Após esses e outros exercícios propostos, Tortelier conta sobre Casals, a fim de embasar seus pensamentos, deixando entrever que, para Tortelier, mesmo a prática de exercícios de técnica, aparentemente antinaturais, podem ajudar a performance, posteriormente:

"Pablo Casals se queixava, às vezes, de alguns exercícios antinaturais que lhe pediram quando ele era um jovem estudante. Entretanto, é duvidoso que eles os tivessem provocado o menor dano. Pelo contrário, poderia se dizer que, de não os haver praticado, não tivesse sido capaz de dominar, como o fez, a técnica do violoncelo ${ }^{11}$."

\footnotetext{
11 "Pau Casals se quejaba a veces de algunos ejercicios antinaturales que le plantearon cuando era un joven estudiante. Sin embargo, es dudoso que le hicieran el menor daño. Por el contrario, podría decirse que, de no haberlos practicado, no hubiese sido capaz de dominar como lo hizo la técnica del violonchelo." (1993, p. 31).
} 
1. 3. William Pleeth, o estudo e a interpretação do violoncelo - Uma leitura de seu livro "Cello"

"Acoerência é o último refúgio dos que não łêm imaginação". OSCAR WILDE

"Maturidade do homem: significa reaver a seriedade que se tinha quando criança ao brincar". FRIEDRICH NIETZSCHE

Este livro pesquisado (Op. cit., 2002) trata de diversos aspectos do universo do estudo, do ensino e do processo de aprendizagem do violoncelo, partindo do ponto de vista da experiência do renomado violoncelista e professor William Pleeth, abordando casos ocorridos em sua experiência própria de aulas e estudos pessoais. Trata, na sua maior parte, do professor, do que ensinar, e de modos de ensino que facilitem a aprendizagem, evitando problemas que ocorrem com freqüência nessa relação de ensino.

Na introdução, feita pelo violinista Yehudi Menuhim, este afirma que lhe parece que conseguir transmitir o alcance, o poder e a amplitude do violoncelo é pelo que mais um professor de violoncelo deve lutar.

Em seguida, em prefácio escrito por Jacqueline Dupré, ela afirma que uma pessoa nunca chega à perfeita performance, mas, ainda assim, desenha um crescente aperfeiçoamento do conhecimento e de percepções, e de entusiasmo, a partir de cada momento. Isso, para ela, torna a música, praticamente, a razão de nossa existência. 


\section{A função da música para determinar a ação física}

A primeira afirmação de Pleeth é a de que "O espírito da música é a única coisa que pode, legitimamente, ditar a ação física no violoncelo". ${ }^{12}$

Para explicar essa afirmação, Pleeth descreve que, em sua concepção, a técnica é descobrir e desenvolver meios de trazer à existência uma peça musical, ou seja, que a técnica per se não pode existir sem a música, à qual deve servir. Para enfatizar essa idéia, diz que a técnica verdadeira não pode ser aprendida, somente a base da técnica, pois a verdadeira técnica só começa a aparecer quando está envolvida em uma idéia musical criativa.

Pleeth afirma que "a música é o veículo da técnica". Para reforçar essa idéia diz:

“(...) Uma vez que somos atingidos no momento musical e espiritual de uma peça de música, e usamos a música como veículo para levantar nossa técnica e conduzila em seus novos reinos, as possibilidades de progressos técnicos e de desenvolvimento tornam-se intermináveis. Quanto mais engrandecemos nossos espíritos através da inspiração musical dos grandes mestres que escreveram para nossos instrumentos, mais nós iremos descobrir sobre nossa técnica e como ampliá-la para representar os papéis que eles criaram ${ }^{13 "}$.

\section{Os problemas do fanatismo pela "técnica"}

O autor desabafa que um comum fanatismo pela "técnica", ou seja, a prática da técnica como um fim em si mesmo, o preocupa, pois um professor gostaria de ver alunos que trabalhassem com imaginação e organização, além de um real entendimento da validade dos aspectos mais sutis. E afirma que, ainda que bem intencionada, uma abordagem puramente técnica rumo à perfeição pode levar, posteriormente, a um bloqueio de qualquer desenvolvimento técnico. Para ele, nós não podemos escapar do fato de que quando nós impomos uma separação da técnica em nosso tocar, também impomos limitações que, no fim, vão deixar a música, a técnica e os poderes expressivos vazios.

\footnotetext{
12 "The spirit of music is the only thing which can rightfully dictate physical action on the cello". (2002, p. 2)

13 “(...) Once we are hitched on to the musical and spiritual momentum of a piece of music and use the music as a vehicle to lift our technique and carry it into new realms, the possibilities for technical progress and development becomes endless. The more we enlarge our own spirits through the musical inspiration of the great masters who have written for our instrument, the more we are going to discover about our technique and how to stretch it to portray the roles they have created." (2002, p. 2)
} 


\section{A busca da unidade ao se tocar}

Por isso, o autor prega que devemos sempre buscar uma unidade ao tocar, que seria composta de três partes: corpo, emoção e mente, em vez do que é habitualmente empregado, que Pleeth define como "eu versus meu cello, e nós dois contra a música". Para ele, existem muitas maneiras de se tocar uma peça "corretamente", do ponto de vista do que o compositor pediu, contudo, essa unidade (corpo, emoção e mente) deve estar sempre presente.

Para tanto, ele acredita que essa unidade deve ser estimulada e cultivada desde as primeiras aulas de um aluno; mesmo quando se está apenas tocando as quatro cordas em pizzicato, a fim de se ensinar quais são as quatro notas da afinação do instrumento, deve ser incentivada a criação de sensações, climas e caracteres, que estimulem a imaginação e a fantasia, desde o começo: ou seja, uma atenção à relação entre a ação física e o som, a emoção ou uma idéia. A partir desse bom começo, o crescimento unificado deste aluno vai continuar por toda a sua vida musical, e a sua abordagem em relação a tocar o violoncelo será a de viver a música, e não apenas manipular técnicas de um instrumento.

Pleeth acredita que estamos sempre expressando nossas sensações ao tocar o violoncelo, independentemente de nossa vontade, e que, para ele, o parceiro mais maravilhoso do nosso coração está em nossas mãos - seus gestos são a expressão externa do que sentimos internamente. Afirma que cada vez que fazemos um golpe de arco ou quando posicionamos um dedo numa corda, nós causamos uma sensação de som e de sentimento.

Contudo, apesar deste pensamento, ele declara saber que a natureza de nosso labor é tal que é necessário estar sempre analisando os movimentos físicos quando tocamos, mas que devemos ter a consciência de que não é essa análise que faz tais movimentos acontecerem. Se alguém sente a ação, a sensação em sua mão (com seu ouvido como guia e mestre) pode analisar isso posteriormente, se quiser. Mas que nunca devemos produzir um movimento partindo de uma análise abstrata: há muitos outros fatores sutis trabalhando ao mesmo tempo.

Um gesto, normalmente, segundo o que afirma Pleeth, nunca precede o sentimento ou emoção que o gera, em qualquer que seja o movimento do dia-a-dia, como acenar, sorrir, ou levantar os ombros, por exemplo. A emoção acontece primeiramente, e a ação física responde a essa emoção. Muitas vezes, os violoncelistas, 
em seus estudos, tentam produzir uma ação física antes de experimentar alguma emoção que sugira essa ação, que é parceira necessária desta. Se o estudante descobrir isso e alimentar essa energia, vai aprender como o espírito pode alimentar a técnica, e como a técnica, desse modo, pode carregar a música nos seus ombros.

\section{Em busca de uma ação natural}

Devido a essas idéias expostas, Pleeth alerta para os perigos de se isolar a "ciência" na investigação da técnica. Essa idéia é concebida, usando, nesse caso, o conceito de ciência como uma investigação intelectual sobre os movimentos físicos no violoncelo. Pleeth afirma que, muitas vezes, os movimentos feitos por um violoncelista são analisados friamente, fora do contexto artístico ou musical, e por isso acabam desenvolvendo a teoria antes de terem entendido o que se passa, criando, dessa forma, uma base artificial para a ação física, destruindo a ação natural e ridicularizando a natureza dos movimentos.

Com essa idéia arrevesada, segundo Pleeth, a ciência acaba se tornando o fim, a meta última, e a música, apenas um produto desta ciência.

\section{Perigos da busca pela perfeição técnica}

$\mathrm{O}$ autor considera, portanto, que, ainda que almejemos uma base técnica que necessite ser aperfeiçoada, e que busquemos por fórmulas, estas só podem fazer sentido dentro de um contexto musical muito maior. Fórmulas, em sua visão, podem ser perigosas quando o que seria uma ação básica se torna um fim, ou seja, a própria e única ação. Considera ainda que, em busca de uma perfeição cada vez maior dessa técnica, os violoncelistas estão deixando de atingir tudo aquilo que essa mesma técnica destrói.

Quando a ciência (ou seja, a busca puramente técnica, nesse caso) é isolada, como um fim em si mesma, Pleeth acredita que o instinto (que define como sendo algo primitivo e maravilhoso), definha antes que seja permitido à pessoa se desenvolver em sua plena maturidade.

O autor afirma, ainda, que nos grandes artistas existe uma perfeita fusão da ciência, natureza e instintos musicais, e que qualquer ouvinte perde a consciência da separação delas como entidades diferentes. Para o autor, o ato de tocar deveria soar tão 
não-científico e desinibido quanto o canto de uma pessoa que nina uma criança, que está totalmente em contato com sua expressão musical instintiva.

\section{A necessidade da existência de uma busca direcionada no estudo}

Outro problema comum do estudo de um violoncelista, para o autor, é uma ausência de uma busca. A prática é tornada, muitas vezes, uma rotina repetitiva de movimentos técnicos, em que não se busca nada, especificamente. A saída para essa questão deveria ser uma busca do conceito integral da música ou passagem musical, de sensação, do que a música almeja.

Procurar, na prática, um tipo de sensação e emoção que estão ligados ao que estamos tocando, ainda que o tocado sejam escalas, arpejos, ou qualquer exercício técnico: elas têm um andamento, uma articulação, uma intensidade, e todos esses aspectos podem ser intensificados com esse equilíbrio de sensação física e intelectual, além do sentimento, anterior à ação. Isso gera a criação de um equilíbrio e um prazer muito maior, em qualquer prática.

\section{O "aquecimento criativo"}

Pleeth sugere que, no primeiro aquecimento técnico de manhã, por pelo menos cinco minutos, o façamos ad libitum, de forma que o próprio corpo e suas necessidades físicas se desenvolvam instintivamente. $\mathrm{O}$ autor acredita que, a cada dia, temos uma necessidade de aprendizado diferente e que, a partir desse "esquentar" indiferente às regras de prática e de métodos, a emoção se libera, o corpo se libera, e estes dois nos guiam sempre para algum tipo de exercício de que precisamos naquele dia.

Para ele, mesmo cinco minutos de um tocar livre, de pura fantasia, ajudam o aquecimento, como pessoa completa, não somente dos dedos, e trazem todos os aspectos do que é tocar: "Por que precisaríamos calar a mente musical e o coração, em qualquer ponto, pelo caminho?". ${ }^{14}$

Para validar essas idéias, Pleeth cita que Pablo Casals, por sua conta, fez um hábito começar cada dia tocando um pouco de Bach, justificando que era para "santificar" a casa, como ele mesmo afirmava. Pleeth considera uma ótima idéia, não somente para santificar a casa, mas para santificar a mente, pois acredita que o espírito

\footnotetext{
14 "Why should we shut out the musical mind and heart at any point along the way?" (2002, p. 10)
} 
entra em contato com algo maravilhoso e dá um algo a mais ao corpo para iniciar os estudos. Assim, afirma: “(...) No fim, não é tanto uma questão de praticar algo, mas de vivê-lo, de uma forma completa e então iniciar a prática". ${ }^{15}$

\section{“Como estudar?"}

William Pleeth conta que estudantes perguntam, freqüentemente, aos seus professores como eles deveriam estudar, o que prova que já de início eles foram guiados na direção errada, pois não se sentem realmente confortáveis com as maneiras tradicionais propostas, esperando fórmulas mágicas, pré-fabricadas, ou seja, um sistema externo que os conduza a algo realmente eficiente. Nesse caso, então, Pleeth afirma que essa fórmula mágica deve ser pessoal e individual, e que deve vir de dentro, de uma maneira criativa.

\section{A luta do violoncelista contra o violoncelo}

Acredita também, baseado em sua experiência como professor, que muitas pessoas sentem que se não estiverem lutando contra o violoncelo (e contra eles mesmos), não estão trabalhando com propriedade. Acha que os estudantes têm um complexo de culpa por não ter "praticado", e que isso mostra quão arrevesadas estão as idéias sobre as necessidades de estudo individuais, e, por conseqüência, a arte individual, no geral. Por isso, Pleeth pensa que devemos sempre ter em mente que não há duas pessoas iguais, com temperamentos, disposições e necessidades físicas iguais, nem mesmo uma mesma pessoa é igual, de um dia para outro.

E afirma: "Sob diferentes condições, nós deveríamos ser capazes de nos usarmos de formas completamente diferentes ${ }^{16}$ ".

\section{O uso do "dia desfavorável" para a prática criativa do estudo}

O autor pensa também que existem muitas maneiras aproveitáveis de usar um dia desfavorável (entenda-se desfavorável como os dias em que estamos com maiores dificuldades físicas, motoras, e até mesmo com menor paciência), para aperfeiçoar um diferente tipo de prática, que será útil no próximo "dia bom”. E crê também que a

\footnotetext{
15 "In the end it is not so much a matter of practising (sic) something, but of living in a complete way and then starting to practice." (2002, p. 11)

16 "Under different conditions we should be able to use ourselves completely differently". (2002, p. 12)
} 
prática precisa ir se desenvolvendo e mudando dia a dia, pois as necessidades vão mudando da mesma forma, como um bebê, que, crescendo, necessita de diferente dieta para seu diferente estágio de desenvolvimento.

Com isso, critica a idéia freqüentemente usada que procura, dentro de uma rotina de prática tediosa e pouco criativa, a segurança, que é baseada, muitas vezes numa prática que sempre gira em torno das bases da técnica, a fim de evitar o medo de errar nas coisas mais simples. E se pergunta se isso seria devido ao fato de que, sendo um ser humano, a pessoa temeria falhar, ou se seria apenas uma busca fanática por segurança.

Pleeth afirma que, devido ao temor de falhar, até mesmo a base de técnica já aprendida pode ser bloqueada pelo medo, e que muitos erros podem acontecer, gerando cada vez maior necessidade dessa "prática técnica", a fim de dar uma segurança, que, devido ao temor crescente, não ocorrerá.

\section{$O$ violoncelista $\mathbf{x} 0$ atleta}

Outro fator bloqueador do desenvolvimento integral (artístico, técnico, físico, musical) seria, para Pleeth, uma busca frenética por mais altos graus de desenvolvimento técnico, uma realização gradual de determinados tipos de exercício, no sentido mais superficial, tratando o violoncelo como algo parecido aos Jogos Olímpicos, como ele mesmo afirma, no qual pode ser medida a capacidade de um artista em termos mensuráveis de velocidade, de amplitude do som, certas formas de agilidade, e muitas outras formas do uso do violoncelo que primam, na maior parte dos casos, cada vez mais pela velocidade e agilidade.

Para o autor, quando os alunos são estimulados apenas no crescimento técnico, em busca de movimentos cada vez mais perfeitos, muitas vezes acabam nem fazendo idéia ao que esse desenvolvimento deveria estar ligado.

\section{O prazer e as facilidades de tocar em busca da expressão}

O pior aspecto dessa busca puramente técnica é que ela pode tornar o aluno desprovido de motivação para o estudo, pois o instrumento vira uma obrigação, não mais um meio de expressão pessoal. Dessa forma, qualquer prazer é perdido, ou vem apenas ligado à satisfação de cumprimento de metas mecânicas e físicas, esquecendo-se dos ganhos de vida que uma busca da arte, da sensação, da expressão, dos climas e 
humores, da pureza e beleza do som, pode gerar nesse mesmo aluno. Esses ganhos, para Pleeth, podem sempre ser uma motivação autêntica para a prática diária.

O autor descreve uma aluna sua, tocando um trecho de cordas duplas, do primeiro movimento do "Concerto em lá m", de Saint-Saëns, em que tudo estava muito correto, mas soava como uma completa autômata. Ele disse que ela não sabia quão bem os dedos dela já sabiam aquela passagem, e lhe pediu que tirasse completamente sua mente dos seus dedos, que deixasse que eles "dessem uma voltinha". Depois, enquanto ela tocava, falou com ela, a fez falar com ele, olhar uma pintura na parede, e não só ela tocou a passagem quase duas vezes mais rápida (e ainda assim corretamente), como lindamente, segundo ele, "e com um olhar em seu rosto!". Ou seja, Pleeth diz que essa aluna poderia estudar da mesma antiga maneira, para o resto da vida, sem melhorar muito, mas sem nenhum brilhantismo e sem nenhuma vida.

\section{A distração dos aspectos técnicos ao se tocar musicalmente}

Por tanto, Pleeth aconselha que na medida em que as mãos estiverem suficientemente familiarizadas com as notas, devemos deixá-las caminhar livremente, buscando formas de nos distrairmos dos aspectos técnicos e mecânicos, "deixando acontecer”. Isso nos ensina sobre confiança em nós mesmos. Tocar parece muito difícil para todos aqueles que querem ter o controle consciente a cada momento, e essa preocupação física e mental interfere tanto na maneira de tocar, que tudo deixa de ser natural. Ele nos lembra "daqueles fantásticos instrumentistas ciganos", que devido ao fato de ter uma não estudada naturalidade, têm incrível facilidade técnica.

E conta:

"Quando eu digo a alguém 'Seja imprudente nessa passagem, seja um diabo, e vá', estou tentando destruir essa autoconsciência, super-calculada, essa 'técnica' determinada que é tão errada quando se encontra face a face com o conteúdo expressivo da música - e que, de fato previne o músico de alguma vez entrar em contato cara a cara com o conteúdo expressivo da música. Sendo um pouco descomedido e caminhando com seu trabalho, confiando um pouco, voando cego um pouco mais bravamente, são formas importantes de contra atacar uma atitude extremamente medrosa, extremamente científica ${ }^{17}$ ".

\footnotetext{
17 "When I say to someone, 'Be reckless in that passage, be a devil and have a go', I am trying to destroy a bit of this self conscious, over-calculating, determined 'technique' that goes so wrong when it comes face to face with the expressive content of the music - which, in fact, effectively prevents the player from ever coming face-to-face with the expressive content of the music. Being reckless a bit and getting on with your work, trusting a bit, flying blind a little bravely, are important to counteract an over-fearful, over scientific attitude." (2002, p. 16)
} 


\section{Como estudar métodos de maneira proveitosa}

Sobre livros de estudo, ou os chamados métodos, Pleeth faz um alerta sobre o seu mau uso: o autor rejeita a idéia de quem critica os limitados meios de aprendizagem de um método, e também de quem os usa como único meio de aprendizado, ou até mesmo uma finalidade a ser atingida. Para ele, os métodos são algo de onde sempre se pode extrair aprendizado, como se fossem uma casa maravilhosa onde vamos entrar, mas afirma que cada estudante faz o método. Tratando cada exercício como portais a serem visitados, o autor alerta que o que aprenderemos de qualquer exercício está em cada aprendiz, na sua maneira de olhá-lo, e até mesmo em multiplicá-lo em inúmeros exercícios úteis para a reflexão das fraquezas individuais de cada estudante.

Uma pessoa deve se perguntar sempre: $O$ que posso aprender com esse exercício? Quantas mudanças positivas posso obter com esse exercício? Quantas nuances estão mostradas e podem ser desenvolvidas com esse exercício? Para o autor, até mesmo em uma simples barra de compasso pode haver um exercício de aprendizado musical e técnico, e essa visão mais abrangente deve partir do aluno, em seu estudo individual, principalmente, ainda que possa ser estimulada pelo professor. Não existe nenhum proveito em quantidades de exercícios "feitos", pois, para o autor, os estudos devem ser encarados como estudos para a vida toda, e não como algo burocrático que se cumpre, e em que depois se passa para a etapa seguinte.

Uma vez desenvolvido esse hábito de "quebrar" um estudo em inúmeros miniestudos, segundo Pleeth, o aluno, ou violoncelista, pode levar esse modo de estudar a qualquer passagem, peça musical ou método; ou, seja, o aluno que se culpa por ter estudado apenas uma sonata, por exemplo, durante uma semana, e não haver estudado nenhuma técnica, pode ter estudado técnica de muitas formas (inclusive de forma melhor do que se tivesse apenas estudado técnica, segundo ao autor), se estiver estudando numa correta direção de pensamento, multiplicando aspectos a serem observados em cada compasso, nota, ou trecho.

Por essas circunstâncias, Pleeth defende o uso de concertos de estudo, que têm sido muito negligenciados, mas que contêm tudo aquilo que os grandes concertos possuem, e podem desenvolver o bom hábito de estudo, a musicalidade, a técnica, enfim, muitos aspectos que poderão ser aplicados posteriormente, com maior facilidade 
e já mais incorporados, nas grandes obras, em geral de grandes dificuldades técnicas e musicais.

\section{A mão esquerda}

Em relação à mão esquerda do violoncelista, Pleeth faz uma introdução sobre as maravilhas de um simples movimento de abrir e fechar a mão livremente, e relata que, por acabarmos fazendo esses movimentos instantaneamente, deixamos de ver a que beleza que existe neles, e também a ligação que qualquer movimento das mãos tem com nosso lado emocional. Afirma que a mão é um espelho da intenção musical e que, se vamos tocar para um bebê ou um homem grande, por exemplo, nossa mão reage imediatamente de modo diferente: é sempre uma resposta a sentimentos e emoções (ou deveria ser). Nas infinitas formas de expressão estão as infinitas formas de toques e sensações das mãos.

$\mathrm{O}$ autor considera que existe um tremendo potencial de variedades em cada simples frase musical, tudo isso em resposta às sensações e aos sentimentos internos. Esse, para ele, é o tipo de conhecimento que devemos buscar nas sensações físicas de nossas mãos (principalmente da esquerda, cujos movimentos parecem muito mais mecânicos), e não uma atividade de movimentos pré-organizados e aprendidos com grande habilidade e esforço.

Por isso, Pleeth é totalmente contrário à "forma de mão", correta e pré-moldada. Ele considera essa idéia uma grande inimiga da liberdade da mão esquerda, principalmente no que diz respeito às respostas emocionais e musicais que ela pode ter aos nossos sentimentos e sensações. Ele acredita que essa idéia, ainda que defendida por inúmeros violoncelistas, prejudica inclusive a afinação, pois limita o potencial de variedade expressiva; defende ainda que muitos problemas de afinação de muitos violoncelistas residem no fato de estarem com a maior parte dos dedos em cima, ou nas posições já prontas, e acreditarem falsamente que por isso estarão mais afinados.

Alguns até mesmo acreditam que podem medir a distância dos semitons pelo grau de tensão ou abertura de seus dedos; contudo, na prática, em situações reais de tensão, em que acabam levando a mão ou os dedos "para lá e para cá", como ele descreve, podem desafinar as notas. $\mathrm{O}$ autor diz que enquanto uma afinação básica deriva de uma mais ou menos lógica divisão da corda, a boa afinação depende muito de 
uma capacidade antecipada de prever a sensação sonora que o ouvido deseja ter, de uma nota para a outra.

Devemos, para Pleeth, saber ver, em algum ponto de nosso desenvolvimento, que as divisões pré-concebidas das afinações são apenas aproximadas e básicas, e que as sutilezas devem ser buscadas individualmente, por inteligência e instinto. Ou seja, se nos fixarmos sempre nesse esquema básico, préfabricado, que nos ajuda, com certeza, no início, nossas mãos irão liderar a afinação, e não nossos ouvidos, o que William Pleeth acredita levar a "um tipo de desastre musical" ou, "pelo menos, mediocridade da afinação", o que também acredita ser um "desastre musical".

"O tradutor da distância entre os dedos no espelho é e deve ser sempre o ouvido $^{18 \%}$. Ele compara o ouvido do músico aos olhos do escultor: os olhos é que guiam as mãos ao escultor, assim como os ouvidos devem guiar as nossas. Assim como os olhos podem antecipar uma reação do escultor, nossos ouvidos também podem antecipar as nossas. Contudo, alerta que somente uma mão relaxada e flexível pode chegar a receber a informação dos ouvidos.

\section{Regras para dedilhados}

O autor também chama a atenção para que se evite demasiadas regras para dedilhados, pois devemos sempre explorar novos dedilhados, que podem trazer inúmeros benefícios tanto a determinadas passagens quanto a facilitar um trânsito livre da mão (o menos "pré-fabricada" possível) pelo espelho. Não devemos buscar conforto e segurança de dedilhados, e sim aquele que reflete melhor a cor, o espírito, o sentimento.

Para ele, não só é um direito do violoncelista explorar novos dedilhados, senão uma obrigação. $\mathrm{O}$ aluno, desde o princípio, deve ser encorajado a quebrar a regra dos dedilhados impressos, buscando seu maior conforto pessoal e uma razão, quer seja física ou musical, para sua escolha. Os dedos, contudo, devem ser sempre usados da mesma maneira livre com que são usados numa mudança de posição, inclusive em uma posição "fixa".

18 "The translator of distance on fingerboard is and must always be the ear." (2002, p. 25) 


\section{Mudanças de posição}

Para Pleeth, as mudanças de posição também devem ser realizadas com o mesmo senso de liberdade de todo o braço, e alerta que, devido ao fato do cello ser um instrumento muito grande (e daí decorre certo pânico às mudanças), a sensação de maior velocidade necessária para as mudanças é aumentada, ainda que seja uma falsa noção. Uma mudança muito rápida pode ser expressiva, dependendo do contexto; contudo os sentimentos gerados pela música devem gerar a sensação da velocidade devida, para cada mudança, em cada contexto. Ele relata dizer para o aluno: "Tome o seu tempo na mudança $^{19}$ ", não para que ele seja descuidado com o tempo, mas porque existe um tempo emocional e mental nessas mudanças.

Pleeth afirma que as mudanças de posição devem ser sempre variadas, para aumentar o potencial de variedade expressiva: em climas, sentimentos, sensações, velocidades, leveza, peso, e que, apesar de haver nelas um equilíbrio entre tensão e relaxamento, as mudanças devem sempre se iniciar de um ponto máximo de relaxamento possível. Aconselha a tentar sempre sentir, nas mãos e nos braços, o relaxamento, visto que é sempre mais fácil falar dele do que fazê-lo, e que é impossível explicar a sensação de relaxamento; cada um só pode perceber essa sensação tentando senti-la, vivê-la, aplicando, na prática, o que é ouvido sempre na teoria.

\section{A importância da tensão: energia $x$ esforço}

O autor também alerta que existe, sim, um grau de tensão necessário, para cada música e cada contexto, mas que essa tensão é muito mais ligada à energia aplicada na música, do que a esforço. Contudo, durante mudanças de arco ou posição, por exemplo, essa tensão musical não deve ser aplicada. Com a habilidade de relaxar no momento inicial das mudanças, o violoncelista é capaz de atingir não somente extremos de tensão ou delicadeza nas mudanças, mas qualquer grau de tensão ou relaxamento entre esses extremos.

\section{Coordenação entre mão direita e esquerda}

Outra particularidade técnica tratada por ele é o correto "casamento" entre mão esquerda e direita. O autor afirma que para o bom funcionamento entre as mãos é

\footnotetext{
19 “Take your time in shift”. (2002, p. 34)
} 
necessário compreender em que sentido elas têm que trabalhar em conjunto, e, ao mesmo tempo, de que forma elas devem ser independentes entre si. Por isso, ele alerta para que se perceba sempre os diferentes graus de tensão com os quais as duas mãos devem trabalhar. Esses graus são quase sempre muito diferentes, muito independentes entre si, e se um violoncelista igualar (ou tentar igualar) tais graus de tensão, vai, com certeza, por um caminho errado.

É claro que, em teoria, sabe-se que o potencial de poder dinâmico é muito maior na mão direita do que na esquerda, e que não há sentido, por exemplo, em crescer o grau de tensão na mão esquerda, ao mesmo tempo em que é necessário na direita, para se tocar um forte, por exemplo, pois esse acréscimo de tensão na esquerda não aumentará em nada a dinâmica da música. Ainda assim, na prática, isso deve sempre ser evitado, pois é uma reação automática natural. Segundo Pleeth, ainda, essa seria a razão do uso indiscriminado de um vibrato muito rápido e amplo, pois a mão esquerda "não conseguiria resistir" ao aumento do grau de tensão da direita, usando também muita energia.

Pleeth narra que, em muitas circunstâncias nas quais o comando técnico vai estar em uma mão ou na outra, é importante focar a atenção apenas em uma mão, aquela que estiver fazendo o trabalho menos difícil ou importante, a fim de permitir que a outra se liberte e "vá para um passeio", em suas palavras, relaxando de tensões, podendo até mesmo cumprir melhor suas tarefas.

\section{O arco}

O autor valoriza especialmente o trabalho da mão direita, que é considerada injustamente como tendo um trabalho mais simples do que o da mão esquerda, em uma análise superficial. Mas aponta que, nesse "aparentemente simples" serviço de ir para cima e para baixo (em linguajar musical, tendo em vista que, para um leigo é mais o movimento de vai e vem ${ }^{20}$ ), está uma incrível gama de poder expressivo, que necessita de uma proporcional gama de técnicas para criar todo esse potencial.

William Pleeth diz ser necessário pensar no arco como o ar, como a respiração. Comparando com o ar aplicado por instrumentistas de sopros, aconselha a pensar no braço direito como sendo a respiração ou os pulmões, e o pulso e os dedos como sendo

\footnotetext{
${ }^{20}$ Nota desta pesquisadora.
} 
os movimentos da língua e dos lábios. Para ele, devemos procurar sentir esse "sopro de ar" muito livremente, tanto em arcadas grandes como em pequenas, e alerta para que nunca restrinjamos os movimentos, no caso de sermos violoncelistas pequenos ou de braços curtos, pois a tendência de permitir tais restrições é grande, nesses casos.

"Poder nunca é uma questão de apertar o arco na corda, mas de saber até que ponto relaxar com a finalidade de criar um equilíbrio entre a pressão e a velocidade entre tensão e relaxamento ${ }^{21}$ ". E diz que o comando do arco depende ainda da capacidade de o violoncelista criar sons iguais tanto no arco para baixo como para cima, afirmando que o arco para cima deve ser particularmente estudado, pois seu potencial é muito comumente ignorado pelos cellistas.

Para ele, devemos sempre ser capazes de executar qualquer golpe de arco perfeitamente, tanto no arco para cima quanto no arco para baixo. Se cairmos na preguiça habitual de sempre adotar a maneira mais conveniente de golpe de arco, nunca seremos capazes de desenvolver e até mesmo de explorar a técnica de outros modos. E se estivermos realmente treinados para obter qualquer som ou articulação com qualquer golpe de arco, só o que mudará serão os meios para produzi-los.

"Não é suficiente, em sua arte, rejeitar algo baseado em pura teoria ou hábito, somente; nós devemos estar, constantemente, explorando e buscando por meios técnicos que vão gerar uma melhor realização da música ${ }^{22}$. O autor afirma que muitas das vezes em que escolhemos arcadas, com a justificativa de serem fisicamente mais corretas ou fáceis, estamos empregando-as pelo simples hábito de fazê-las. São mais fáceis fisicamente, somente porque já as utilizamos inúmeras vezes e estamos acostumados a esses padrões, e não porque sejam realmente mais fáceis. Afirma ainda que se formos capazes de pensar puramente num sentido expressivo do arco, fazendo uso de um braço esquerdo totalmente livre, essa sensação desconfortável de uma "arcada errada" raramente existirá.

Alerta para uma visão estreita dos violoncelistas em relação ao legato, como sendo apenas um tipo de articulação, chamando a atenção para o fato de que, como é muito fácil fazer duas notas ligadas no instrumento de cordas, refletimos muito pouco a

\footnotetext{
21 "Power is never a matter of grinding the bow into the string, but of knowing at what point to release in order to create a balance between pressure and speed - between tension and release." (2002, p. 46)

22 "(...) It is not sufficient in our art to reject something on pure theory or habit alone; we should be constantly exploring and searching for technical means which will give better realization to the music." (2002, p. 49)
} 
respeito das inúmeras possibilidades de tirar som num legato. Chama a atenção para o fato de que os pianistas, que têm muito maior dificuldade para realizar isso, devido à própria natureza do instrumento, sempre buscam diversos tipos de timbres e articulações sutis dos legatos, enquanto que os músicos de cordas se contentam em encostar o arco na corda e puxá-lo.

Em relação às notas em spiccato, a preocupação dos violoncelistas, segundo Pleeth, é sempre muito maior; contudo, ele afirma que a natureza do arco é pular. Nesse caso, o papel do instrumentista seria dar suporte a essa natureza e canalizar as articulações em spiccato para a altura, densidade ou leveza, ou quaisquer outras qualidades desejadas.

\section{Em busca de movimentos naturais}

Um ponto relevante, apresentado por Pleeth, é o que faz crer que parece haver sempre um desejo de erigir barreiras em relação ao uso correto que se faz dos dedos, pulso e braço direito (ou até mesmo esquerdo) nos movimentos de arcadas, tanto grandes quanto pequenas. Em quaisquer outras circunstâncias de movimentos físicos ou manuais que executamos no dia-a-dia, na maior parte das vezes, não há qualquer "problematização" ou pensamento preocupado quanto às minúcias que devem ser observadas ao se executar determinado movimento.

O autor dá o exemplo de quando vamos escrever algo pequeno, ou algo grande, como numa folha de papel, ou num quadro negro. É inimaginável que durante tal movimento pensemos: "agora vou usar mais os dedos e o pulso", ou ainda "agora usarei a parte superior do braço", por exemplo. Simplesmente o fazemos, de maneira natural e adequada.

Pleeth acredita que, como nós já sabemos de antemão, ao iniciar o estudo de um instrumento, se tratar de tarefa que necessita de uma habilidade altamente desenvolvida, essa idéia nos faz imediatamente acreditar que os mesmos movimentos naturais, usados em milhares de outras atividades costumeiras, devem ser especialmente desenvolvidos e treinados, além de concebidos intelectualmente, antes de serem realizados, para que, enfim, se concretizem. Baseadas nesse engano, muitas pessoas constroem sua "técnica", cheia de preconceitos (no sentido de pré-conceitos), barreiras e limites. 
1. 4. Gerhard Mantel e os movimentos corporais aplicados ao violoncelo - Uma leitura de seu livro Cello Technique

"Estar consciente de um só dos seus próprios defeitos é mais útil do que estar informado de mil deles por uma outra pessoa." TENZIN GYATSO, Dalai-Lama

Em seu livro Cello Technique (Op. cit., 1995), Gerhard Mantel tem a intenção de expor inúmeros aspectos físicos e racionais que circundam o ato de "tocar violoncelo": técnica básica, interpretação e mentalidade ao se estudar o instrumento. Isso inclui abordagens de como se posicionar com o violoncelo, como segurar o arco, como tirar som da corda, as posições da mão esquerda, o arco e suas incontáveis possibilidades, entre muitos outros itens, descrevendo-os, baseado em sua experiência como professor e como violoncelista. Por ser bastante abrangente, é considerado por muitos como leitura obrigatória para um violoncelista, inclusive como bibliografia em universidades americanas, nos cursos de Cello Performance.

No prefácio de seu livro, Janos Starker afirma que a maioria dos métodos se refere a resolver problemas específicos, e, muitas vezes os livros com muitos pontos de vista interessantes acabam sendo invariavelmente curtos ao se referir às temáticas relacionadas com o violoncelo, sendo esta a grande vantagem do livro de Mantel: a de que ninguém pode afirmar que esse livro "não é suficiente", pois discute inúmeros aspectos conceituais e motores de se tocar violoncelo. Starker diz ainda que ajuda a explicar as várias maneiras de se tocar o instrumento nas diferenças que são reais, semânticas e naquelas que são apenas questão de gosto.

Sua afirmação mais contundente é a de que para ele é urgente que este livro seja leitura obrigatória para aqueles cuja vocação na vida seja a responsabilidade de ensinar às futuras gerações a tocar o violoncelo.

A tradutora Barbara Thiem, em sua nota inicial, diz que esse livro cobre o solo que é a base indispensável sobre o qual qualquer técnica de som deve ser construída.

Mantel, em sua introdução, constata que seu livro não tem a intenção de ser um 
método de violoncelo, pela razão de já haver inúmeros bons métodos, que servem tanto de guia para os professores como também de material prático, e que têm a função de construir a técnica sistematicamente. Afirma que esses livros descrevem o processo de aprendizado desde as primeiras tentativas, e por isso têm grande importância na pedagogia do cello.

$\mathrm{O}$ autor revela que seu livro tem o intuito de questionar o que acontece quando alguém toca um instrumento, o que faz um instrumentista eficiente de maneira distinta da de um instrumentista menos eficiente. Mantel acredita que poucos livros têm essa segunda abordagem, que observa as causas de sucesso e fracasso.

\section{O "conceito-meta"}

O autor é categórico ao afirmar que praticar sem uma idéia acurada do que é necessário praticar é uma perda de tempo (1995, p. xiv). Ele diz ainda que, apesar dessa idéia parecer óbvia, é mais significativa quando fazemos as perguntas: Qual aspecto da técnica estamos estudando agora? Ritmo? Afinação? Memória? Qualidade de som? Tempo? Precisão conceitual? Fraseados? Coordenação entre a mão esquerda e a direita? Exame das tensões corporais? Elegância do movimento? Energia e perseverança? Mantel afirma que temos escolha de muitos aspectos, e que, por isso, naturalmente, é impossível se concentrar em todos eles ao mesmo tempo. Em uma boa sessão de prática, somente alguns aspectos devem ser considerados ao mesmo tempo.

Mantel ainda acredita que se, nessa prática, o ponto mais importante a ser considerado naquele momento não for considerado, o estudante não somente não terá nenhum progresso, como provavelmente ainda fará danos, tendo em vista que tocar bem determinada passagem passa pela repetição freqüente, a fim de torná-la automática.

O professor atenta para o fato de que muitas instruções, úteis em determinados contextos, podem ser falsas quando generalizadas, e são, algumas vezes, geradas por uma aceitação simplista ou não-crítica de instruções tradicionais passadas de professor para professor. Mantel acredita que as instruções que não podem ser explicadas verdadeiramente não dão ao estudante a oportunidade de experimentar as próprias sensações individuais, em se tratando de essas instruções serem úteis ou não. 


\section{Tensões físicas e sua ligação com o lado emocional}

Contudo, para ele, a técnica deficiente corrompe o resultado sonoro e, mesmo em um músico criativo, interfere em seus resultados. Outro problema comum tratado por Mantel é o da tensão física combinada a um constante desapontamento que, eventualmente, cria um estado de frustração, o que faz decair o rendimento artístico. Por outro lado, o controle técnico estimula a busca por novas nuances expressivas.

Assim, Mantel assegura que a técnica não pode ser separada da experiência de se fazer música, mas que é possível, no entanto, dividir o processo completo de se tocar em seções lógicas que podem ser aprendidas e pensadas separadamente. Acredita que, para fins práticos, podemos separar a técnica da interpretação e, ao mesmo tempo, obter um ponto de partida para a análise dessa técnica.

\section{Itens a serem observados, ao estudar}

Para observar esses aspectos, Mantel cria uma série de itens a serem observados: 1. A personalidade do músico, com toda a sua imaginação, energia, sentimentos e conhecimento disponíveis, criam os standards.

2. Essa personalidade cria um conceito musical dos resultados desejados.

3. Para realizar esse conceito, o músico necessita de conhecimento detalhado das demandas do instrumento, e insights (possivelmente intuitivos) da relação necessária entre o som e a produção física.

4. O corpo deve ter a habilidade de transformar essas demandas em movimentos, e o instrumento deve ser manuseado com a necessária força e flexibilidade.

5. Todos esses fatores levam ao que ele denomina de "conceito-meta", que inclui as posições no espelho ${ }^{23}$ e a afinação pré-concebida, que também é baseada na memória dos movimentos requisitados. Mantel acredita que, para a mão esquerda, esse "conceito meta" antecipa o fim do movimento, enquanto que, para a direita, ele controla o curso do movimento.

6. Em resposta, esse "conceito-meta" inicia o movimento. A meta, contudo, pode ser atingida com diferentes movimentos.

7. Certas sensações motoras, que podem ser mais ou menos distintas, acompanham cada movimento.

\footnotetext{
${ }^{23} \mathrm{O}$ espelho aqui tratado como parte do violoncelo, como sinônimo da madeira escura sobre o braço do violoncelo, e não no senso comum.
} 
8. Essas sensações exercitam um "controle parado sobre o movimento", pela comparação contínua (inconsciente) com a meta, e a correção destes movimentos.

9. Para o autor, esse "conceito-meta", o movimento e as sensações formam um controle complexo e inter-relacionado.

10. O movimento finalmente acontece.

11. Outro mecanismo de controle, o ouvido, compara o resultado sonoro obtido com o conceito musical e novamente influencia a "meta conceitual" do movimento.

\section{Treinamento do músico}

Gerhard Mantel alerta para o fato de que as demandas musicais não podem ser executadas enquanto os músculos não estiverem treinados para o movimento desejado, e que uma percepção errônea do resultado sonoro final, muitas vezes, prejudica as correções necessárias. Aconselha também que um conceito impreciso gera um movimento também impreciso.

Outra idéia relevante tocada por Mantel é a que afirma que as tensões são o espelhamento corporal dos efeitos da esperança e do desapontamento.

O violoncelista afirma que a experiência de tocar é uma unidade, e que embora as duas mãos tenham funções diferentes, a cooperação delas não pode ser dividida entre "esquerda" e "direita", pois um movimento ideal realizado em uma delas interfere na outra, assim como um movimento errôneo e tenso também. O movimento ideal só pode ser sentido por toda a unidade do corpo, e requer tensões inconscientes de alguns músculos para manter o equilíbrio de toda a unidade do corpo, bem como seu balanço. Para ele, os movimentos dos dedos são somente a última instância.

Mantel expõe que os músicos de cordas são dependentes de suas habilidades conceituais, desde o início, ou seja, a capacidade que se tem de fixar um local no espelho de uma maneira "quase visual", como uma meta espacial de um movimento, sem erros. Ou seja, que se deve imaginar marcas claras no espelho, sem ajuda visual, mas sim com uma forte memória espacial, corporal, também ligada ao tato. Ao que esta pesquisadora também entende como uma meta de grande precisão, mesclada destes fatores: memória corporal, tátil, espacial, quase como se pudéssemos memorizar a exata posição em que o corpo todo se encontra para ser capaz de encontrar aquela determinada nota, naquela determinada posição. 
Nesse ponto, pode-se dizer que Mantel é radicalmente contra o tão conhecido, usado, comentado, criticado e usado Método Suzuki, que inicia a questão do aprendizado das distâncias entre as notas com marcas que podem ser vistas, coladas no espelho, o que esta pesquisadora pode dizer, por experiência letiva, que em alguns casos e com alguns alunos que acreditam necessitar de muitas "muletas" didáticas para memorizar a distância entre as notas e as posições, pode ser muito prejudicial.

Devido ao fato de estarmos sentados atrás (ainda que lateralmente) do violoncelo, muitos alunos iniciantes, com isso, acabam se "entortando" totalmente e "desmontando" toda a postura ereta inicial, preconizada para se sentar ao violoncelo, apenas para poderem olhar para as "marquinhas" coladas, o que, nessa fase de aprendizado pode ser particularmente prejudicial para a postura, dado o grau de desconforto que o aluno ainda tem com o instrumento, o que pode levar a dores e insatisfação ainda maiores.

\section{Conceito-meta}

Mantel acredita que o conceito acústico do som deve gerar o movimento, ou, ao menos, deve vir como força motriz do movimento, e, então se unir ao fator da sensação corporal do lugar determinado da nota. Ou seja, o "conceito-meta" deve partir do som e para ele, a concepção quer dizer antecipação. Segundo o autor, quando praticamos passagens rápidas, devemos praticá-las, inicialmente, somente de maneira muito devagar, pois as passagens rápidas escapam das habilidades analíticas do olho. Estamos praticando, contudo, não a fluência, mas a consciência das alturas das notas. Apesar de exaustivo, esse método produz óbvios e imediatos resultados, segundo ele. O que, como afirma, não é o caso de inúmeras horas de prática de "chutes" de acertos e erros, o que ele chama de "several hours of 'hit os miss' practicing".

Mantel afirma que muitas tensões que ocorrem não são resultados de movimentos incorretos, mas apenas uma vaga concepção da meta. Essa insegura concepção, que resulta do medo de falhar, cria tensões musculares que afetam os braços durante momentos cruciais do movimento e, dessa forma, mudam todo o padrão de atividade muscular.

Para ele, como estamos sempre tentando aperfeiçoar nossos movimentos, uma meta conceitual precisa é ainda mais importante, e ela resulta da soma das experiências 
coletadas pelas freqüentes repetições de um movimento e todas as sensações motoras resultantes dessas repetições. A superioridade de resultados gera uma boa associação das sensações motoras com os movimentos bem sucedidos.

\section{Percepção corporal}

Quanto maior percepção corporal a respeito das tensões, mais precisamente os impulsos de correção dessas tensões trabalharão. Além disso, para Mantel, a concepção do som e do lugar da nota deve preceder o movimento, em uma mudança de posição. "Concepção significa, nesse contexto, antecipação ${ }^{24}$."

\section{Diferenças ao se tocar trechos rápidos e trechos lentos}

E, para ele, tocar uma seqüência de notas rápidas é basicamente diferente de tocá-las rapidamente. Em passagens rápidas, os movimentos individuais são combinados em um padrão de movimento, o que não ocorre em uma passagem rápida. Para Mantel, no caso de passagens rápidas, essas não podem ser antecipadas nota por nota, mas devem ser estudadas anteriormente, em uma pulsação lenta, e convertidas em um padrão de movimento. Este, sim, será antecipado.

Então, o autor propõe alguns modos de se estudar, que, segundo ele, funcionam mais rapidamente. Ele acredita que devemos praticar sempre lentamente, como já foi dito, estudando a consciência das alturas, que ele chama de pitch consciousness. E essa consciência "geográfica" eventualmente ajudará na fluência, já que a clara concepção e consciência tornam possível a posterior fluência.

Já a forma final do movimento, que é um movimento composto por vários movimentos individuais, não pode ser estudada dessa forma.

\section{Tensões musculares}

Como já foi dito, uma concepção insegura, e o conseqüente medo do possível fracasso resultante, criam tensões musculares que afetam os braços durante momentos cruciais, afetando todo o padrão de atividade muscular. Assim, o movimento memorizado no estudo não é utilizado, já que ele relembra todo um diferente padrão muscular. Dessa forma, são gerados resultados ainda mais instáveis e inseguros, criando

24 “Conception in this context means anticipation”. (1995, p. 10). 
um círculo vicioso ao qual os estudantes não estão freqüentemente atentos.

\section{O que se busca no estudo}

Para Mantel, no estudo, estamos procurando maneiras de aumentar a precisão dos movimentos. Para que isso se torne possível, a precisão da concepção das metas é fundamental. Temos que idealizar a "memória dos movimentos", como sendo a soma das experiências coletadas durante o estudo.

A superioridade de um intérprete, para Mantel, está não na memória de padrões bem definidos e acabados, mas na sua melhor associação a sensações motoras e a movimentos bem sucedidos.

Um contínuo fluxo de sensações reporta a sucesso ou fracasso dos movimentos. Quanto mais diferenças nas tensões musculares um músico pode sentir, mais precisamente os impulsos de correção trabalharão. Ou seja, quanto maior a percepção corporal, mais facilmente o músico pode se corrigir.

E Mantel afirma ainda: quanto menores as tensões musculares, mais precisos o feedback e o controle. A precisão é maior se o corpo e os músculos estiverem em movimento, e não parados, de forma estática, fixa. Alerta que temos que tentar manter o menor nível possível de tensão em todos os músculos envolvidos em um certo movimento.

\section{Energia x Esforço}

Mantel considera que não há razão ou função em se limitar a quantidade de energia que usamos. $\mathrm{O}$ autor afirma que o completo relaxamento de qualquer músculo é impossível. Certa quantia de tensão existe, ainda que se sinta, ou que pareça que o músculo está completamente relaxado. Apenas manter uma determinada posição das juntas já requer trabalho muscular, assim como o equilíbrio do corpo todo. A gravidade puxa para baixo até mesmo o corpo sentado, principalmente se o equilíbrio estático for alterado, ainda que de maneira mínima.

Mantel alerta que sempre é melhor alterar uma postura a suportar um movimento “muscularmente". É importante que o corpo esteja pronto para se mover o tempo todo, pois um corpo flexível reage com uma mudança adequada de postura, em vez de tensionamentos musculares. 
Aconselha a evitar movimentos bruscos, pois esses movimentos tendem à inexatidão, especialmente quando mudanças de posição estão envolvidas. Qualquer mudança de arco ou de posição envolve transferências de peso e pequenas correções na postura, pois todo o corpo está envolvido (ou deveria estar), mesmo em um simples movimento.

As causas das tensões musculares, segundo Mantel, em geral são duas: ou o movimento requer muita força em relação ao que se propõe, ou é executado com exagerada rigidez das juntas envolvidas. A segunda razão é a mais difícil de resolver, já que é freqüentemente combinada com tensões psicológicas. $\mathrm{O}$ autor sugere que sejam feitos, nesses casos, exercícios de relaxamento fora do violoncelo, pausas maiores entre os períodos de estudo, exercícios de respiração, análises do movimento no tempo, aperfeiçoamento da concepção-meta, e até mesmo dormir, a fim de eliminar ou apaziguar essas tensões.

\section{Estudo $=$ desenvolvimento da coordenação motora}

Embora seja necessário manter a atividade muscular em um esforço mínimo, não é verdade que tocar vigorosamente não requer muita força. Mantel afirma que a flexibilidade também é indiretamente dependente de reservas de energia, que um músculo exaurido, cansado, excessivamente "treinado", não possui. As propostas de exercícios e estudos, embora muitas vezes sejam vistas como necessárias para se aumentar a força muscular, tem como sua maior função desenvolver a coordenação motora dos movimentos.

Por isso, quanto maior a reserva de energia, maior a energia disponível para se tocar sem tensão. Ou seja, para aumentar a energia disponível, temos que aumentar as reservas de energia.

\section{Modos errados de estudar}

Mantel lembra que é notado que ao se treinar exercícios até o limite da exaustão e depois descansar, para novamente treinar até o limite e descansar, e assim sucessivamente e, dessa maneira, sempre se chegar a um limite um pouco maior, o que é chamado nos esportes de "interval trainning", quando aplicado ao violoncelo (por exemplo, em trinados com cordas duplas), fazem a força e o controle decrescerem 
visivelmente durante o processo. O padrão de movimento sempre entra em colapso, mesmo antes que a flexibilidade dos dedos sofra.

Por isso, acredita que somente exercícios isométricos são capazes de fortalecer os músculos diretamente. Afirma que, da medicina esportiva, aprendemos que exercícios isométricos aumentam a força muscular, mas não a velocidade de uma função muscular.

Para treinar a velocidade, seria necessário optar por movimentos isotônicos, que combinem uma leve força muscular, com o movimento das juntas envolvidas. É importante, para Mantel, que se use, normalmente, 2/3 da energia disponível, pois menos traria pouco desenvolvimento dos músculos, e mais seria extenuante e surtiria efeito contrário, ou seja, diminuiria a energia disponível.

\section{Organização dos movimentos pelo conceito-meta}

Mantel afirma que a concepção-meta tem o efeito de um campo magnético, que organiza os movimentos a cada vez, em um padrão similar, e que qualquer movimento dirigido pela meta consiste em uma combinação de vários movimentos parciais, que não devem ser vistos como a soma dos movimentos aprendidos individualmente, mas sim como uma resultante, em que o movimento corporal é dirigido pelo conceito-meta.

Outro dado relevante exposto por Mantel é que a exata reprodução de um movimento é impossível, em qualquer circunstância. Daí se deduz que é inútil tentar memorizar padrões de movimentos idênticos, ou tentar reproduzir padrões musculares idênticos de movimentos, enquanto se pratica. Movimentos que parecem idênticos sob um olhar menos analítico, são realizados com diferentes forças musculares ou até mesmo com grupos musculares diferentes. Portanto, a sensação de se "memorizar um movimento" pelos músculos tem de ser observada com critério.

\section{Corpo fixo x Corpo em movimento}

Mais energia é gasta para se manter uma posição do que para executar um movimento. Esta pesquisadora acrescenta que, em prática de Ioga, por exemplo, a postura mais difícil e mais desgastante de se executar e se manter por um longo tempo é simplesmente a posição sentada, com as costas eretas e os joelhos cruzados (posição de 
lótus, ou meio lótus, que é a posição normalmente empregada para a prática da meditação), que poderia ser vista, por um observador menos consciente, como sendo apenas uma posição de descanso do corpo.

Ou seja, mais energia do corpo é gasta para se manter uma posição durante um tempo do que para se executar um movimento fluente, em um determinado momento, o que aponta para o fato de que um movimento será mais preciso e fácil de se executar quanto menos posições fixas sejam empregadas nele.

Mantel afirma ainda que o que é funcional pela economia, controle e precisão, também é esteticamente gracioso e harmonioso, declarando que o que se vê bonito, soa bonito. ${ }^{25}$ A sensação desse tipo de movimentos, que ele chama de movimentos Gestalt, não é sentida individualmente, mas como uma totalidade. Por isso o autor acredita que é difícil corrigir um movimento tecnicamente errado, pois é necessário também corrigir a sensação física do movimento.

Outra hipótese em que o autor acredita é a de que uma informação sobre uma posição torna-se muito mais acurada ao cérebro quando é percebida e obtida por um movimento, e não por uma posição fixa: ou seja, se uma junta fica rígida durante um movimento, essa junta não transmite qualquer informação sobre sua posição e localização ao cérebro. Deste modo, quanto menos o corpo se movimentar como um todo, menos vai perceber e mais esforço terá para memorizar o estudo praticado.

$\mathrm{O}$ autor ressalta até mesmo que alguns movimentos não realmente necessários, podem, com freqüência, ser úteis, já que a idéia não seria primariamente usar o mínimo de energia possível, mas, sim, obter os mais acurados resultados com a energia disponível. Essas idéias, na observação desta pesquisadora, contrariam um senso comum de que técnica seria uma busca de "economia de movimentos", que resultariam em maior acuidade. Deste modo, o autor reforça que o princípio de economia precisaria ser redefinido como um princípio do mínimo esforço, independentemente do trabalho realmente realizado.

Ao se tocar violoncelo, Mantel acredita que os dedos definem como o resto do corpo deve se mover, e que a polaridade entre os dedos das duas mãos produz o movimento total do corpo. Por isso, tensão em uma das mãos vai gerar uma diminuição da sensibilidade na outra mão. Assim, Mantel propõe que, para contrabalançar esse

\footnotetext{
25 "What looks good, sounds good". (1995, p. 27)
} 
efeito, façamos sempre pequenos movimentos nos dedos da mão direita em mudanças de posição da mão esquerda, durante o movimento ou brevemente antes dele. Ele acredita que o aumento de sensibilidade e controle da mão esquerda será surpreendente.

Propõe também um leve movimento de pulso da mão direita, um pouco antes das mudanças de posição da esquerda, o que faria aumentar a sensibilidade do pulso. Mantel diz que se esta mudança de posição coincide com uma mudança de sentido do arco, apenas pode-se enfatizar o movimento de pulso natural da mudança.

Gerhard Mantel se arrisca a dizer, exagerando um pouco, que a segurança da mão esquerda depende da flexibilidade de todas as juntas do braço direito.

\section{Mudanças de posição}

Para Mantel, na técnica de instrumentos de corda, o problema de mudanças de posição ocupa um lugar especial, pois a solução deste problema determina a habilidade de se tocar ou não afinado. Nesse caso, é bom levar sempre em consideração o fato de que um movimento executado com menos esforço é mais fácil de controlar. Além disso, pode-se pensar que, já que a aceleração de um objeto é dependente de seu próprio peso, além da força aplicada nele, uma contração muscular em uma parte mais leve do corpo ou do braço causará maior aceleração do que se for feita em um lado mais pesado do corpo.

\section{Vibrato}

Outro ponto apresentado por Mantel é o uso do vibrato. O autor acredita que esse uso cresceu muito nos instrumentos de cordas, geralmente visto como uma necessidade estética, e que quando um instrumentista é perguntado sobre as razões do seu uso, usualmente faz ligação com o vibrato "natural" da voz humana, que é copiado pelos instrumentos "que cantam". Essas razões, obviamente não explicam o porquê de o vibrato da voz humana ser considerado belo. Além disso, Mantel afirma que estudos feitos com vozes não treinadas contradizem a afirmação de que o vibrato é natural na voz.

Por essas razões, Mantel acredita que podemos chegar à conclusão que o vibrato é um meio aplicado conscientemente para intensificar a expressão. 
O autor trata ainda do fato de que o vibrato, sendo uma variação cíclica da altura da afinação (e ocasionalmente, também, uma variação cíclica no volume do som), parece contradizer o desejo principal da precisão da afinação. Contudo, seu uso pode ser explicado pela referência do fenômeno psicológico que a atenção de alguém é atraída mais por mudanças no ambiente do que por um estado particular das coisas. Assim, uma uniformidade é vista como estática. Por essa razão, a fim de prevenir que um som sustentado seja notado apenas no seu início, fazemos variações cíclicas que mantém a atenção focada no som, para que, desse modo, ele seja apreciado em toda a sua duração.

Logo, pode-se deduzir dessa idéia que um som com variação cíclica constante também será sentido como estático, e, por isso devemos também alterá-lo sempre para um vibrato mais rápido, mais lento, mais cheio, mais leve, acelerando ou ao contrário, dependendo sempre do contexto musical que se deseja expressar: "Com a finalidade de prender a atenção completa do ouvinte, é necessário modificar continuamente um vibrato tecnicamente perfeito ${ }^{26}$ ".

Mantel afirma que essas pequenas irregularidades não serão percebidas como tais pelo ouvinte, mas que a estrutura da frase não será convincente se a continuidade e a variação da intensidade não forem atingidos.

\footnotetext{
26 "In order to catch the full attention of the listener it is necessary to modify continuously a technically perfect vibrato." (1995, p. 98)
} 
1. 5. Mstislav Rostropovich: compilação das idéias transmitidas em quatro aulas dezembro de 2000 e abril de 2001

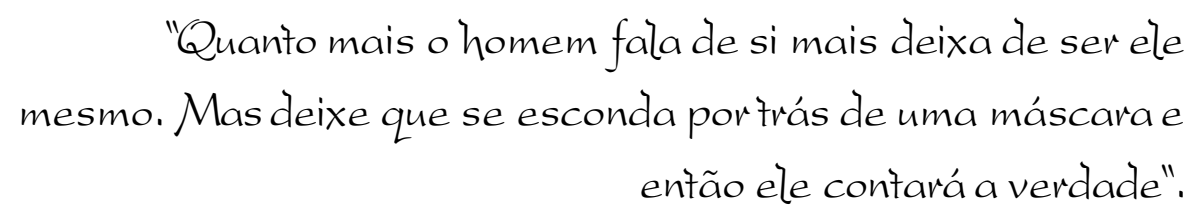

OSCAR WILDE

"Para quem busca o conhecimento, portanto, e não o ópio de crenças bem enraizadas no solo do acreditar, surpresas e anomalias são achados valiosos. A descoberta de um fato surpreendente leva à procura de novos fatos e suscita a formulação de hipóteses e teorias que possam elucidáto. A mente aberta ao conhecimento trabatha como um radar alerta, ligado ao anômato. Asurpresa é o estopim do saber, uma janela entreaberta para o desconhecido. Diante dela, o pensamento amanhece e desperta do torpor dogmático. 'Uma dificuldade é uma luz; uma dificuldade insuperávelé um sol".

EDUARDO GIANNETTI

"Dios łodavía no ha creado el mundo; sóto está imaginándoto, como entre sueños. Por eso el mundo es perfecto, pero confuso".

"El mundo", AUGUSTO MONTERROSO

Em dezembro de 2000, durante o período de uma semana, e, posteriormente, em abril de 2001, durante mais uma semana, foi concedida a esta pesquisadora uma oportunidade única e indescritível: quatro aulas individuais e muitas conversas pessoais, tidas durante caminhadas, refeições e concertos, com o violoncelista russo Mstislav 
Rostropovich. Intérprete, professor e maestro de renome internacional, dono de uma carreira das mais importantes entre os músicos do séc. XX, Rostropovich, infelizmente, faleceu no dia 26 de abril de 2007, aos oitenta anos de idade, contando com 76 anos de estudo do violoncelo (tendo iniciado aos quatro), deixando um legado musical tão extenso quanto importante para a história do violoncelo. Note-se que essa não é uma opinião pessoal desta pesquisadora, mas uma incontestável opinião de todo o meio musical mundial.

Na semana de dezembro de 2000, tratada acima, Rostropovich regia a Orquestra da Filadélfia, na cidade da Filadélfia (EUA), e na semana tratada de abril de 2001, regia a Orquestra do Teatro Colón, de Buenos Aires, também em Buenos Aires (Argentina).

Nessas quatro aulas e conversas, foram transmitidas a esta pesquisadora, de modo muito generoso, muitas das opiniões pessoais de Rostropovich sobre técnica, ensino, estudo e interpretação do violoncelo, que merecem ser respeitadas, difundidas e repensadas cuidadosamente por todos os que se interessam pelo violoncelo. Ainda que algumas dessas idéias possam gerar discussões ou contrariedades, é da opinião desta violoncelista que devem ser analisadas com grande reflexão e cuidado, avaliando os contextos nos quais tais idéias foram explicadas, e suas aplicações.

A tônica marcante, nessas aulas e conversas, foi, sem dúvida nenhuma, o domínio do arco, assunto base para praticamente todas as discussões e recomendações. Falou-se disso na maior parte do tempo. A outra tônica, também muito discutida, foi a da mentalidade que se deve ter ao estudar. A respeito desse ponto, recomendaram-se um planejamento, um empenho profundo e irrestrito ao estudo do instrumento, uma busca incessante e incansável pela evolução, pela capacidade expressiva livre, pela superação de debilidades técnicas, deixando sempre muito clara a sua opinião de que qualquer pessoa, com empenho e direcionamento correto, pode vir a tocar muito bem o violoncelo, independente da idade, do instrumento, do tipo físico, das condições de estudo, entre muitos outros fatores.

E deixou três grandes lições de humildade: primeiramente, ajudou, com uma disponibilidade incrível de tempo e de empenho, esta pesquisadora, que na época contava com apenas seis anos de estudo de violoncelo, com todas as debilidades técnicas que tinha esta aluna brasileira, que iniciou tardiamente seus estudos do instrumento (praticamente aos dezoito anos) e que sempre necessitou dividir seu tempo 
entre o trabalho e o estudo, ao invés de ter tido uma realidade ideal, voltada apenas aos estudos musicais.

A segunda grande lição de humildade foi ao final da quarta e última aula, quando praticamente colocou esta pesquisadora para fora da sala de sua suíte de hotel, alegando que tinha que estudar uma música (apontando-a para sua estante de partituras), que era "muito difícil". E isso, do alto de 70 anos de carreira, tendo sido solista por incontáveis vezes, acompanhado das melhores orquestras e maestros do mundo, tendo gravado praticamente todas as importantes obras do repertório do instrumento, entre muitas outras marcantes atividades de sua carreira.

A terceira grande lição dada foi talvez a mais simples e, muitas vezes, a mais difícil de se aplicar verdadeiramente: "Você quer ser uma grande cellista? Seja humilde." Difícil de se realizar, pois a humildade verdadeira implica diversos tipos de atitudes que vão além de não se sentir superior aos outros jamais e de tratar a todos bem: a humildade está na atitude que temos com infinitos aspectos do dia a dia, desde adotar uma atitude de respeito com todas as coisas e criaturas, a nossas dificuldades e conquistas diárias, à obra interpretada e a seu compositor, até valorizar diariamente, e sem excessos, as pequenas coisas que aprendemos, cada fonte de aprendizado, ou mesmo ter uma atitude também respeitosa, de imensa gratidão, com relação às inúmeras possibilidades de aprendizado (inclusive aprendizados de vida) que um instrumento musical, colocado abraçado ao nosso corpo, pode gerar.

Esta autora acredita que uma atitude humilde, num sentido positivo, que não tem relação com a abnegação, também pode estar em lembrar que o violoncelo é um companheiro que não está a nossa frente, somente, mas ao nosso lado, fazendo parte da invenção de sons que estamos prestes a gerar, como se fosse um parceiro de dança. Parceiro talvez seja a palavra correta, porque também depende do instrumento (bom ou ruim) que tocamos muitas das qualidades dos sons gerados, dos timbres, e também depende de descobrirmos, humildemente e pacientemente, dia-a-dia, como esse instrumento específico responde melhor, soa melhor, como extrair dele o melhor possível. Parceria seria a palavra mais aplicada a essa relação, e uma boa parceria também se baseia na humildade. Como disse a grande violinista Bettina Stegman, certa vez, a esta pesquisadora: "Tirar do instrumento o som mais lindo do mundo". 
A seguir, serão apresentadas algumas das recomendações feitas por Mstislav Rostropovich em aula, relativas à técnica e à interpretação.

\section{Exercícios de técnica básica}

Nas aulas, o Prof. Rostropovich era quase sempre muito contundente e enfático com qualquer afirmação, relativa à técnica ou interpretação, praticamente tratando quaisquer idéias suas como sendo "verdades absolutas" e indiscutíveis. Para deixar bem claro o que queria dizer, repetia os mesmos conceitos muitas e muitas vezes durante suas aulas, falando essas "frases de efeito" em tom mais alto do que as demais, e frente a qualquer fisionomia de surpresa ou dúvida desta pesquisadora, repetia, fazia gestos e micagens, "atuava" as situações, querendo convencer absoluta e definitivamente esta aluna de qualquer idéia que ele estivesse defendendo.

Rostropovich declarou diversas vezes, tanto nas conversas quanto nas aulas, a importância que ele vê no estudo da técnica diária e de muitas e muitas horas de estudo. Disse que é possível estudar em um ano o que se estudaria em seis, mas também, estudar em seis anos o que se poderia ter estudado apenas em um, dependendo do grau de empenho, horas de estudo, além de um estudo desenvolvido corretamente, com inteligência, o que ele afirmava ser ainda mais importante. Daí decorreu um dos ensinamentos mais relevantes de todos os contatos feitos nessas duas semanas de convivência: que devemos estudar o que é difícil, e não o que já está fácil, pois estudar algo que já está bem entendido e assimilado é, segundo ele, uma grande perda de tempo.

Com esse assunto, Rostropovich era muito enfático e repetitivo, tanto nas aulas e conversas de dezembro de 2000, na Filadélfia, quanto nas aulas de abril de 2001, em Buenos Aires: o violoncelista praticamente implorou para que se estude sempre o que parece complicado. "Se é fácil”, dizia, “jogue no lixo! Nunca mais fazer!”. Isso, afirmava, era primordial para contribuir com um aprendizado realmente rápido. E dizia a esta aluna: "Estudar o que é complicado, como um teimoso, até sair. Quando ficar fácil, nunca mais fazer!"

E, igualmente contundente, perguntou por muitas vezes se esta autora queria ser uma boa violoncelista. E à resposta afirmativa, sempre seguia o seguinte conselho: “fazer, no mínimo, uma hora de escalas e arpejos por dia". E ainda insistiu: "Você quer ser uma boa violoncelista mesmo? Estude pelo menos uma hora de escalas e 
arpejos, todos os dias". E quanto aos dedilhados de escalas e arpejos, recomendou que se estude todos os tipos possíveis de dedilhado, que o aluno não deve se prender a um dedilhado "preferido", com a finalidade de gerar maior conhecimento do espelho, maior liberdade em qualquer outra circunstância, para que, quando um desses dedilhados diferentes aparecer em alguma peça ou concerto, já esteja absorvido e estudado, sempre “de cor", realmente enfatizava.

E falou uma frase, inúmeras vezes repetida, durante as quatro aulas, e que soa como uma "bomba" a praticamente qualquer estudante ou violoncelista: "O medíocre estuda aquilo que está saindo bom, porque gosta de agradar seu próprio ouvido. $O$ gênio estuda o que está saindo ruim".

Afirmou que o estudante deve fazer como um esportista: treinar todos os músculos separadamente. Sugeriu treinar as pequenas coisas, para depois poder ter uma boa performance geral; gerar, no estudo técnico individual, facilidade de fazer os detalhes de arco e mão esquerda, separadamente, para depois tocar bem qualquer concerto ou peça importante.

\section{Dinâmicas}

Em relação às diferenças de dinâmicas, Rostropovich pediu que, nos fortes, se pensasse em "tirar férias", ou seja, fazer pouco esforço, aplicando o peso do corpo para fazê-lo, enquanto que nos pianos disse que seria necessário "trabalhar" muito; ou seja, há muito mais esforço para se fazer os pianos que os fortes, pois estes fortes são resultado apenas do relaxamento do peso do braço. E afirmou ainda que "O forte tem que parecer tranqüilo e deve ser feito sem esforço".

Sobre os crescendos, o violoncelista disse que é preciso fazê-los também com o vibrato, aumentando sua amplitude e velocidade, ou diminuindo-os, para decrescer, pois se deve explorar esse fator expressivo da técnica, também na sensação de aumento e diminuição de dinâmica que esse recurso gera.

E, finalmente, em relação aos pianos ${ }^{27}$, Rostropovich disse que devem ser sempre pianíssimos. Qualquer ouvinte atento às suas interpretações teve a oportunidade de comprovar que esse recurso era um conceito que o violoncelista Rostropovich aplicava verdadeiramente, e não somente recomendava, pois era uma das "marcas

\footnotetext{
${ }^{27}$ Aqui a palavra "piano" usada no sentido de dinâmica suave, não do instrumento.
} 
registradas" de suas interpretações: os pianos eram pianíssimos muito exagerados, e havia, sempre, em suas interpretações, um intenso contraste de dinâmicas.

\section{Para a qualidade do som}

Em escalas que começam com notas presas, Mstislav Rostropovich afirmou que não se devem usar cordas soltas, para que se mantenha uma sonoridade uniforme.

\section{Sobre o polegar da direita}

Para Rostropovich, o polegar da mão direita deve ser relaxado e leve, e posicionado na borda direita (na visão do próprio violoncelista) do polegar direito, encostado na borda do círculo interno da noz do talão, com as duas primeiras falanges retas (o que declarou ser típico da "escola russa"), sem movimentar a primeira articulação das duas falanges, contudo sempre muito leve e relaxado. Declarou que, nessa posição, é muito fácil estar com o polegar tenso e duro, bem como os músculos que o sustentam na mão, logo abaixo do polegar, e por isso deve-se ter um cuidado muito grande de deixá-lo realmente relaxado.

\section{Sobre o arco}

Com essa posição de polegar descrita acima, o pulso da mão direita, naturalmente, é induzido a ficar mais baixo, em uma linha não quebrada de antebraço e dorso da mão. Essa posição (muito contrária à escola francesa, utilizada por Paul Tortelier e Pierre Fournier, por exemplo), segundo o próprio Rostropovich, confere mais peso natural ao braço, e conseqüentemente ao arco, proporcionando um som mais pesado, mais forte, mais característico da "escola russa" e melhor para se interpretar o repertório romântico e contemporâneo, segundo ele. O professor afirmou que esta escola prejudica um pouco da mobilidade de pulso, por exemplo, em golpes de arco menores e mais sutis, mas que o fato do som forte sem esforço ser imensamente facilitado compensa uma possível perda.

Sobre arcadas, Rostropovich recomendou usar sempre arcos muito longos para se obter mais som e ter o som menos "apertado ${ }^{28}$ ". Incentivou fazer parecer que o arco seja curto demais, e não o contrário. E novamente soltou uma de suas "frases de efeito":

\footnotetext{
28 "Apertado", aqui, tem o sentido de um excesso de pressão na corda que bloqueia a vibração e produz um som excessivamente duro, forte, porém sem reverberação.
} 


\section{“A diferença entre um violoncelista bom e um medíocre são os três centímetros a mais de ponta e os dois de talão que o medíocre nunca usa".}

Em mudanças curtas de arco, recomendou manter o contato, o mesmo peso de braço. E ao colocar o arco na corda, para iniciar uma arcada, afirmou que é necessário colocar o arco na corda caindo com o braço em movimento redondo.

Sobre o "vai e vem" das arcadas, o Maestro afirmou que o pulso deve estar mais alto no arco para cima, e mais baixo no arco para baixo, para aumentar a capacidade de som, principalmente na arcada para cima, na qual, normalmente, é mais difícil manter a mesma qualidade de som e aderência.

Sobre a técnica de arco, Rostropovich sugeriu um exercício, que, segundo ele, dá uma liberdade muito grande à coordenação motora da mão direita e ao controle de sonoridade entre as arcadas de diferentes velocidades: pediu que se fizessem escalas com variações de quantidades de notas (ou tempos) por arco, mantendo o mesmo som.

Por exemplo, escolhe-se um padrão de números qualquer, que poderia ser:

$1-2-4$

$1-3-4$

$2-4-3$

$5-2-7$

$3-8-2$

$10-1-5$

$15-2-9$

... ou qualquer outro padrão aleatório, de preferência complicado, que se possa inventar.

Escolhe-se e anotam-se esses padrões numéricos, e vai-se tocando a escala com uma nota por arco (arco inteiro), depois duas, depois quatro (como no primeiro exemplo acima), mantendo o mesmo ritmo (semínimas, colcheias, ou o que quer que tenha sido escolhido), e a mesma velocidade para cada nota, com a atenção para manter a mesma quantidade de som. Depois, segue-se com a mesma idéia nas outras variações propostas. Dessa forma, há um treino da relação de aderência, peso, velocidade e qualidade de som, independentemente da quantidade de notas feitas em uma arcada.

O violoncelista chamou a atenção para o fato de que, em músicas, a quantidade de notas por arco varia muito e, como não temos o hábito de treinar esse equilíbrio, a 
sonoridade e a frase ficam altamente prejudicadas. E declarou: "O público quer ouvir somente a frase e não quer saber quantas notas por arco estou fazendo".

Assim, para combater essa falha técnica, seria necessário fazer muitas vezes esse exercício, para melhorar equilíbrio, sonoridade e liberdade de expressão da mão direita. Além desse exercício, o professor recomendou sempre fazer exercícios de variações de arco, para treinar a conexão entre mão esquerda e mão direita, a fim de que essa conexão venha a se tornar cada vez mais fácil, livre e segura.

Condenando uma excessiva e costumeira atenção dos violoncelistas, tanto alunos como professores, com a mão esquerda, a afinação e o vibrato, o violoncelista disse que "Um violoncelista é famoso por sua mão direita, não pela esquerda". Segundo ele, o grande artista torna-se célebre pela sua capacidade de expressão, que, sem dúvida, encontra-se muito mais na mão direita do que na esquerda. Mas, mesmo assim, Rostropovich afirmou que a direita é, quase sempre, muito negligenciada nos estudos do dia-a-dia. Disse que não adianta nada falar de vibrato, por exemplo, se o violoncelista só pronuncia o "bê-a-bá", o seja, se fala apenas "letras soltas", ou "sílabas", fazendo analogia com a língua falada. Para ele, o público quer ouvir palavras belas, frases, parágrafos, idéias, monólogos.

Rostropovich afirmou que o cérebro é o general, as mãos são soldados, e que para gerar essa força de comando, devemos inventar todo o tipo de variação ao se estudar os exercícios e as escalas, por exemplo, em relação às ligaduras: 3 notas ligadas - 2 notas desligadas, 3 notas ligadas - 2 notas desligadas - 4 ligadas; fazer exercícios no extremo do talão e no extremo da ponta do arco; fazer arcos trocando as arcadas costumeiras, invertendo seu sentido para cima e para baixo. Afirmou que devemos poder fazer o que quisermos: na cabeça a idéia vem, e as mãos têm de ser capazes de saber fazer qualquer coisa, facilmente, e isso só vem com um treino "teimoso", conforme aconselhou.

Outra idéia interessante, relativa à técnica de mão direita, tratada por Rostropovich, foi sua maneira peculiar de pensar em como segurar o arco, o que será descrito logo adiante.

As duas idéias que essa pesquisadora via, anteriormente, como sendo de uso corrente pelos colegas violoncelistas e professores, tratam da seguinte maneira:

1. O arco deve ser segurado (ou erguido) com igual trabalho de todos os dedos; 
2. O arco deve ser segurado (ou erguido) com o dedo indicador, o dedo mínimo e o polegar, que formam como um "tripé" de apoio, e ajudados, posteriormente, pelos dois dedos centrais.

Já Rostropovich acreditava que o arco deve ser segurado, principalmente, pelos dois dedos centrais (médio e anular) e o polegar, fazendo um contrapeso do polegar com os dois dedos da frente, posicionando-se imediatamente na direção do centro dos dois dedos. Assim, o dedo indicador (já com menor função, em virtude de o pulso estar em linha reta, e não inclinado, mais baixo no seu lado esquerdo - do ponto de vista do cellista para sua mão direita) e o dedo mínimo, segundo ele mesmo afirmou, categoricamente, teriam função única de equilíbrio, com a finalidade de não deixarem o arco pender nem para um lado, nem para o outro.

Quando esta pesquisadora mostrou surpresa com essa sua teoria, Rostropovich quis saber a razão da surpresa, ou seja, qual a teoria que esta pesquisadora teria aprendido, e quando esta lhe explicou quais seriam as duas teorias anteriores, as mais comumente ensinadas no Brasil, mostrou-se bravo e sem paciência, e bradou que esta violoncelista "jogasse fora" essas informações, e usasse a sua maneira de segurar o arco daquele dia em diante.

\section{Posicionamento do braço}

Para o posicionamento do braço direito, o Maestro Rostropovich disse que o cotovelo direito nunca deve ser alto demais, deve parecer tranqüilo. O cellista não pode nunca parecer que está "brigando" com o violoncelo, conforme lhe parecia essa postura.

\section{Sobre o Spiccatto}

Segundo a aula de Rostropovich, ao se realizar o spiccatto, o botão do arco deve fazer um movimento curto e circular. Para isso, o violoncelista deve mexer o pulso para baixo e para cima, movendo o arco para os lados, ao mesmo tempo. Para exemplificar metaforicamente esse movimento, Rostropovich disse que o segundo dedo da mão direita deve "parecer que está ciscando, como uma galinha". O botão deve se movimentar de maneira circular; mexendo como em uma pequena espiral. E, declarou, com muita ênfase, que é primordial, para um violoncelista, treinar e ter grande domínio 
do spiccatto, pois, segundo ele, "não se pode fazer nada com a música se não se souber fazer spiccatto".

\section{Conhecimento do espelho pela mão esquerda}

Outra recomendação importante que Rostropovich forneceu nessas quatro aulas foi que devemos aprender a colocar o dedo em cima de qualquer nota requisitada (inclusive as mais agudas), sem vacilar: ou seja, "criar um conhecimento do espelho melhor do que o da palma da própria mão", conforme afirmou. E isso só é possível com muito estudo de escalas, de repertório, de bases técnicas, variações de todos os tipos, treino de leitura, estudos, improvisação, inclusive de dedilhados (e essa variação de dedilhados foi várias vezes recomendada), ou seja, muito estudo e muita intimidade com o próprio instrumento.

\section{Plano de estudos}

Rostropovich recomendou ainda que o estudante nunca deve se sentar ao violoncelo sem saber o que vai estudar. Deve, antes, ter um plano de estudos, se possível por escrito, para estudar sempre um pouco de tudo (escalas, estudos, técnica, músicas, partes de quarteto e orquestra, e outros), dividindo racionalmente o seu tempo de estudo para aquele dia, a fim de não se esquecer de estudar nada importante, e, principalmente, com a finalidade de não evitar estudar aquilo que lhe é mais complicado e de que mais o estudante necessita estudar.

\section{Bibliografia de estudos sugerida}

Mstislav Rostropovich aconselhou uma bibliografia de estudos e peças indispensáveis para que um aluno tenha um sólido embasamento técnico, a fim de, posteriormente, poder estudar com maior facilidade e propriedade as grandes obras de repertório. A lista feita à mão por ele foi a seguinte:

- "12 Caprices" - de Piatti

- "40 Studies" - de Popper

- "22 Studies" - de Kreutzer

- "Vocalise" - de Rachmaninoff

- "Scherzo" - de Goens 
- "Fontana" - de Davidoff

- "Nocturne" - de Tchaikovsky

- "Larghetto" - de Haendel (da Sonata para violino)

- "Arioso" - de Bach

- "Concertos $n^{o}$. 1 e $n^{o} .2$ " - de Davidoff

- "Moto Perpétuo" - de Paganini

- “As Seis Suites para Cello Solo" - de J. S. Bach

- "Variações sobre um tema Rococó" - de Tchaikovsky

- Concertos de repertório.

\section{Efeitos dessas idéias para esta pesquisadora}

Para narrar os efeitos posteriores dessas aulas para esta pesquisadora, é necessário fazer esses comentários de uma forma mais pessoal, como em uma aula. Por isso, esta autora desculpa-se, de antemão, pelo possível excesso de informalidade.

É difícil de expor em palavras os efeitos posteriores dessas aulas e desse inusitado encontro de vidas. Foi, sem dúvida nenhuma, de um efeito transformador e “bombástico", e, ao mesmo tempo, altamente construtivo. É necessário afirmar, com toda a sinceridade possível, e com toda gratidão necessária, que não se passou um dia em que esta pesquisadora não tenha refletido sobre esses encontros, em seus estudos diários como violoncelista, em suas execuções musicais, e que, até mesmo esta dissertação, é fruto das sementes plantadas naqueles dias de 2000 e 2001.

Os alunos desta pesquisadora também sabem muito bem, e não o desmentiriam, que todas as aulas ministradas por ela, após essas aulas e conversas, tiveram, ao menos uma vez, um comentário sobre as experiências aprendidas com o mestre Mstislav Rostropovich, pelo menos uma de suas "frases de efeito" ou "verdades absolutas" descritas acima, ou das histórias informalmente contadas.

Esta pesquisadora experimentou, por cinco anos, a maneira de segurar o arco, da escola russa, preconizada pelo Prof. Rostropovich, até que resolveu novamente retornar à escola franco-belga ${ }^{29}$, preconizada, por exemplo, por Tortelier, também com razões de experimentação, sem ainda uma opinião de escolha definitiva. É opinião desta pesquisadora que se deve pensar, naturalmente, que não existe maneira certa ou errada

\footnotetext{
${ }^{29}$ Esta diferença será mais bem explicada no início do Capítulo 2.
} 
(apesar de Rostropovich, aparentemente, devido ao grau de contundência, afirmar o contrário), e sim que existem maneiras que funcionam e que não funcionam, para uma ou outra pessoa, e que alguém deve experimentar essas maneiras, e, somente após experimentá-las verdadeiramente, escolher a que melhor se adapta a suas idéias no momento, já com um grau maior de maturidade, ainda que essa idéia deva permanecer sujeita a mudar completamente.

Perguntado sobre quantas horas um violoncelista deveria estudar por dia, o mestre afirmou: "Se é seu aniversário, ou se você vai receber amigos para o jantar, aí você não estuda. Os outros dias você estuda". Deixou claríssimo, assim, que seu ideal de horas de estudo seria mais voltado a "estudar todo o tempo possível e disponível, salvo exceções”. Com essa resposta bem humorada, Rostropovich explica que ser um grande violoncelista está intimamente ligado a uma dedicação exclusiva e a uma persistência disciplinar inabalável (apesar das histórias correntes de que ele mesmo nunca estudou muitas horas diárias).

Com certeza as maneiras de refletir sobre os estudos, propostas pelo Prof. Mstislav Rostropovich, impactaram muito profundamente os estudos e as aulas desta professora e pesquisadora. A grande dificuldade, no entanto, encontra-se em aplicar realmente tais orientações, pois são tão simples de se entender quanto difíceis de se pôr em prática. Em resumo, as idéias mais marcantes foram:

1. Estudo em primeiro e único lugar.

2. Estudar as dificuldades e deficiências.

3. Resolver deficiências.

4. Deixar de estudar o que ficar simples de executar.

5. Estudar muito aquilo de que se deseja fugir.

6. Estudar sempre com um planejamento prévio.

7. Conhecer perfeitamente o espelho.

8. Usar absolutamente toda a extensão do arco.

9. Estudar uma hora por dia de escalas e arpejos, com diversos dedilhados.

10. Sempre tocar de cor (ou seja, decorar tudo o que se estiver estudando).

11. Saber sempre quanta pressão, velocidade, quantidade de crina e de arco, aderência, articulação, dinâmica e intensidade emocional devem ser aplicadas a cada nota, de cada música. 
12. Alguém pode estudar em um ano o que estudaria em seis, ou em seis anos o que poderia estudar em apenas um, e isso é uma escolha pessoal.

13. O músico deve buscar avidamente um perfeito domínio da mente sobre o corpo, da mente sobre a mão esquerda, da mente sobre o braço direito, a fim de que a parte física, técnica, seja inteiramente "esquecida" durante a performance, e que só reste a concepção artística.

Obviamente, todos esses "mandamentos" seguidos tornariam praticamente qualquer "violoncelista medíocre", nas palavras do próprio Rostropovich, "em um gênio", e que apenas um deles rigorosamente seguido, elevariam o nível de performance de qualquer estudante ou profissional. A dificuldade maior, talvez para qualquer um, e em particular para esta pesquisadora, consiste em, adquirido o conhecimento dessas "estratégias", ou até mesmo "táticas" para se tornar um bom violoncelista, aplicá-las dia após dia e ano após ano.

Tal feito exige disciplina, paciência e persistência dignas de um gênio, tal como Rostropovich se mostrou, durante seus brilhantes anos, que o tornaram praticamente uma unanimidade. Sobre esse assunto, pode-se até mesmo arriscar a hipótese, nessa linha de pensamento, de que o tão falado "talento", palavra que esta pesquisadora particularmente rejeita, pode ser apenas uma somatória do uso do conhecimento, da disciplina, do estudo, da paciência e da persistência, além de uma personalidade generosa e especial.

A "fórmula mágica" do sucesso como instrumentista foi dada por ele, assim como agora está sendo repetida, a quem puder interessar. Quem a usará com o devido respeito? Quem aplicará esses princípios, tão simples quanto obviamente eficazes? Quem terá a coragem de usar esse conhecimento? Quem terá o ímpeto de um grande gênio para fazer o que todos sabem que deveriam fazer?

Já se passaram sete anos desses encontros inesquecíveis, o grande mestre faleceu recentemente, tristemente levado por um câncer de intestino, e esta pesquisadora segue tentando aplicar diariamente as lições que ele fazia questão de passar a quem estivesse interessado, a qualquer pessoa, as chamadas "pérolas jogadas aos porcos" e tentando jogar tantas dessas pérolas a quantos estivessem dispostos a recebê-las, usá-las e colher de seus frutos. 
Como disse Jorge Luis Borges, em seu livro Elogio de la Sombra, no texto "Fragmentos de un evangelio apócrifo", reforçando, aqui, o modo de agir de Rostropovich: “33. Da lo santo a los perros, echa tus perlas a los puercos; lo que importa es dar" (Dê o santo aos cachorros, jogue suas pérolas aos porcos; o que importa é dar.). E em seguida acrescenta: "34. Busca por el agrado de buscar, no por el de encontrar..." (Busca pelo prazer de buscar, não pelo de encontrar...). E esta pesquisadora termina por acrescentar outro pensamento de Borges: "15. Que la luz de una lámpara se encienda, aunque ningún hombre la vea. Dios la verá” (1996, pp. 389 - 390), o que poderia ser traduzido como: “Que a luz de uma lâmpada se acenda, ainda que nenhum homem a veja. Deus a verá”.

Sobre a maneira de Mstislav Rostropovich ensinar, a autora Margareth Campbell, em seu livro The great cellists (Op. cit., 1988), relata a visão de dois alunos de Rostropovich sobre sua maneira de lecionar: eles contavam que o centro de sua atividade letiva era alargar a imaginação de seus alunos, a fim de que possibilidades maiores de caracterização e de som pudessem ser criadas. Acrescenta que ele raramente encostava no violoncelo, durante a aula (fato que esta pesquisadora pôde comprovar por si mesma), usualmente usando o piano para exemplificar. Afirma que é verdade que ele era altamente crítico sobre aspectos técnicos, sem maiores buscas por outras qualidades vindas de seus alunos. Campbell afirma, ainda, que ele era muito direto em suas críticas, e as dizia, em seus Masterclasses, para que todos as pudessem ouvir.

Margaret Campbell diz, ainda, que ele era muitíssimo respeitado como professor, desde 1956, quando iniciou sua atividade letiva no Conservatório de Moscou, que sabia se o aluno estava tocando com sinceridade no momento em que esse iniciava sua execução, e que também tinha um sexto sentido para reconhecer potenciais.

A autora desta pesquisa, pela experiência pessoal das quatro aulas e das muitas conversas que teve com o Maestro Rostropovich, concorda com a opinião de que ele era realmente muito crítico com aspectos técnicos, pondo-os sempre em primeiro lugar, muito antes mesmo de qualquer idéia musical (pelo menos ao lecionar), e que a sinceridade das críticas era, de fato, muito grande, muito direta, até mesmo por vezes incômoda e incomum à realidade brasileira, à forma de tratamento que um professor costuma dar a seu aluno neste país. 
Contudo, apesar de o aluno precisar ter uma grande força interior para suportar as críticas mordazes, diretas, mas verdadeiras, como é dito popularmente, "sem papas na língua", (ainda mais vindas de músico de tão grande fama), ele parecia não se preocupar absolutamente com isso, contanto que o aluno estivesse ciente de suas verdadeiras debilidades para que pudesse resolvê-las. Para um educador e, talvez ainda mais para um aluno, a linha que separa a crítica direta e objetiva, que leva a fins práticos de resolução de problemas, da crítica severa e mordaz, que pode desanimar ou gerar desistências, pode ser, muitas vezes, uma linha realmente tênue.

O aluno nunca deve perder de vista, no entanto, que é obrigação do professor ser sincero quanto a seus problemas e debilidades, e que, muitas vezes, a sinceridade e a mordacidade podem ser indispensáveis para que este aluno tome verdadeira ciência de seus problemas, e também do que é mais urgente a ser resolvido. Exageros por parte dos professores podem dar maior percepção, no aluno, de que aquele problema tem grande importância e maior urgência frente aos demais.

Já sobre a maneira como Rostropovich estudava uma nova peça, ou construía a interpretação de uma obra musical, Campbell conta que ele primeiro tomava conhecimento de outras obras do mesmo autor. Depois disso, não tocava no violoncelo, pois acreditava que se fizesse isso, os problemas técnicos ficariam no caminho, e ele necessitava entender primeiro sobre o que era música, quais eram as suas idéias e quais sentimentos ela continha. Lia a peça até que ela soasse em sua cabeça, pois acreditava que era mais fácil lê-la sem som.

A autora conta que, depois, ele descobria em que pontos a música era mais patética, mais luminosa, e também, é claro, onde estava o ponto ápice da peça, o clímax. Ele relatava que assim que entendia onde o clímax estava, começava a compreender a peça. Só então pegava o violoncelo e tocava, com muitos erros, sem dedilhados e arcadas apropriadas. Dizia que era muito ruim ouvi-lo, quando fazia isso. Somente após esses procedimentos é que colocava arcadas e dedilhados. Dedilhados, ele dizia, segundo Campbell, são o que há de mais importante para a expressão da música. Rostropovich afirmava que também necessitava procurar onde estavam os pontos fracos da música, tanto de interpretação como de técnica. E, para ele, estes pontos fracos deviam ser trabalhados separadamente. (1988, p. 286) 
Sobre o potencial expressivo do violoncelo, Campbell diz que Rostropovich afirmava que era o mais maravilhoso instrumento que ele viu na vida, não tanto em poder, mas em qualidade sonora. Afirmava que é "como prata", que amava o som, e que ele tem uma ampla gama de cores em sua voz. (1988, p. 287)

Uma idéia interessante, abordada por Rostropovich, em entrevista realizada por Tim Janof ${ }^{30}$, intitulada Conversation with Mstislav Rostropovich, trata da sonoridade de Rostropovich. Perguntado sobre como conseguia tirar tanto som do violoncelo, respondeu que nunca pensou sobre a sonoridade do violoncelo, especificamente, mas sim que, pelo seu gosto particular pelo repertório romântico, e também pelo repertório sinfônico, concebia o som de um ponto de vista orquestral: "Eu não escuto um som de violoncelo quando eu toco, eu ouço uma orquestra. Eu nunca tentei copiar o som de outro violoncelista. ${ }^{31,}$

\section{Uma história}

Esta autora acredita que é necessário acrescentar, a título de curiosidade, uma história ocorrida nesses encontros. Antes de haver ministrado a primeira aula a esta pesquisadora, por não haver tido tempo hábil para a aula, Rostropovich se encontrou diversas vezes com ela, visto que quis dar a oportunidade de que a pesquisadora assistisse aos ensaios da Orquestra da Filadélfia, que na ocasião ele dirigia, além de tê-la encontrado também em um jantar, cafés da manhã e almoços. Nesses encontros, Rostropovich contou, às pessoas que ele ia encontrando, pelo menos dez vezes a mesma história, sobre uma garota que ele havia escutado alguns dias antes, em Chicago. E dizia: - "Ela era tão ruim, mas tão ruim, eu nunca vi alguém tão desafinado! Um som tão horrível" - e fazia inúmeras caretas e gestos. "Mas tocava com tanto prazer e tanta emoção!... Ela chegou a chorar tocando!...”

Então, o Maestro olhava para esta pesquisadora, sem ao menos tê-la escutado uma única vez, e dizia: - "Você é o Pablo Casals, perto dela!" E seguia repetindo que essa moça era a pessoa mais desafinada que ele já havia escutado.

\footnotetext{
${ }^{30}$ Disponível em: $<$ http://www.cello.org/Newsletter/Articles/rostropovich/rostropovich.htm $>$ Acesso em 13 de novembro de 2007.

31 "I don't hear a cello sound when I play, I hear an orchestra. I never tried to copy another cello sound." (Op. cit., p. 5)
} 
A vários de seus conhecidos que encontrava, acabava contando a mesma história. Num dado momento, ao contar novamente essa história para esta pesquisadora, esta arriscou a pergunta:

“ - Mas, Maestro, você chegou a falar isso para ela?"

Ao que ele respondeu, efusivamente contrariado:

“ - Não!!! Eu não sei como ela vai estar tocando daqui a oito anos!!!”

Dessa história pode-se tirar outra lição muito curiosa: não se deve subestimar jamais o potencial de um estudante, ou mesmo de um músico profissional, pois nunca se sabe como esta pessoa pode vir a tocar, quando estiver empregando o máximo de seu potencial.

Relacionada a esta história, alguns dias depois, no Concerto da Orquestra da Filadélfia, esta autora pôde encontrar com esta moça, a "famosa" personagem desta história, seus pais e sua irmã, que lá foram, de Chicago até a Filadélfia, assistir ao concerto e prestigiar Rostropovich, a convite dele (com despesas pagas, até mesmo de estadia).

Surpreendentemente, a moça em questão devia ter pouco mais de vinte anos, e, mesmo em um nível muito ruim no violoncelo, como o mestre contou tantas vezes, ainda assim ele pôde ver algo de especial nela, dar a ela um grande incentivo, convidando-a, depois da aula, para que fosse com a família ver seu concerto na Filadélfia, como "convidados", como ele dizia (ou seja, pagando tudo a eles), e ainda assim, confiando que, mesmo tocando muito mal, ela poderia vir ainda a tocar muito bem.

Ou, seja, para esta pesquisadora, esta foi uma grande lição de generosidade, de esperança em potenciais ainda não desenvolvidos e de incentivo a uma pessoa anônima, sem grandes talentos aparentes, e com idade desfavorável a uma carreira brilhante, como se esperaria. Assim como foi feito com esta pesquisadora. 
Segundo Capítulo. Cruzamento dos dados apresentados: divergências e convergências encontradas 
Segundo Capítulo. Cruzamento dos dados apresentados: divergências e convergências

\author{
"Épreciso combinar audição, pensamento e mediłação. Não \\ seja muito exigente logo ao início dos exercícios. Vivemos em \\ uma época de łecnologia e de automação, e porisso se \\ poderia pensar que o desenvolvimento interior é também uma \\ prática automática e que bastaria apertar um botão para que \\ łudo aconteça; não é bem assim. O desenvolvimento pessoal \\ não é fácile requer zempo." \\ TENZIN GYATSO, Dalai-Lama
}

Observando as idéias expostas no Primeiro Capítulo por esses cinco músicos pesquisados, podemos ver alguns pontos de interesse, ou até mesmo preocupações, que são idéias pessoais de cada um deles. Há também divergências e convergências de opiniões, que serão agrupadas e repensadas neste Capítulo, tanto como uma recapitulação das idéias mais importantes descritas anteriormente, quanto com a finalidade de facilitar a observação e avaliação dos dados apresentados, nesses contextos específicos.

Apesar da repetição dessas informações aparentemente poder parecer redundante, ela é indispensável para agregar conceitos e permitir comparações mais claras sobre os assuntos, proporcionando uma reflexão mais aprofundada sobre as idéias e as hipóteses apresentadas por esses autores.

Além disso, esses conceitos serão comentados e também serão expostos pontos de vistas convergentes, presentes em outros autores relacionados ao violoncelo e ao ensino de cordas, em geral, baseados em bibliografia pesquisada para este trabalho.

Uma descoberta curiosa também ocorreu durante a pesquisa: em um site extremamente útil e de grande interesse para quem pesquisa sobre técnica ou interpretação do violoncelo, o http://www.cello.org, encontram-se dezenas de entrevistas, realizadas por Tim Janof com grandes violoncelistas atuais, grandes solistas, 
instrumentistas e, muitas vezes, importantes pedagogos e pesquisadores. Janof teve a oportunidade de entrevistar três dos autores pesquisados no Primeiro Capítulo: Rostropovich, Sazer e Mantel. Essas entrevistas vieram afirmar parte das idéias expostas nesta pesquisa como o pensamento desses violoncelistas, bem como complementar este trabalho com informações relevantes sobre os assuntos aqui tratados.

Pode-se pensar que quanto mais radical uma idéia, mais criativa ela pode ser, ou até mesmo, ainda, pelo contrário, que mais facilmente pode ser contestada. Na maioria dos pontos expostos no capítulo seguinte, é possível observar que Paul Tortelier e Mstislav Rostropovich sustentam as suas idéias com particular ênfase, e tratam idéias divergentes como sendo erradas (o que os outros autores têm o cuidado de evitar), talvez por suas personalidades, tidas pelo grande público como marcantes e carismáticas, por suas fortes identidades individuais como artistas e solistas, e, por conseguinte, suas identidades como professores. Devido a esse mesmo radicalismo de opiniões, eles, muitas vezes, se opõem.

É possível afirmar que, dentre os cinco violoncelistas pesquisados, a visão de Sazer é a menos voltada para a questão musical ou para a arte, pois trata principalmente de aspectos de percepção corporal, ligados à técnica do violoncelo (não que isso seja menos importante para uma boa execução). A isso se opõe Pleeth, que afirma que a arte está sempre acima de aspectos ligados à técnica, e acrescenta que a busca de uma individualidade como intérprete é importante em toda a trajetória do violoncelista, inclusive nos primórdios do aprendizado musical e violoncelístico.

Com essa busca de uma individualidade musical concordam o autor Dmitry Markevich (e Pablo Casals). Em seu livro Cello Story (Op. cit., 1984), ele conta sobre o encontro que teve com Pablo Casals, aos oito anos de idade. Seu professor, Maurice Eisenberg, o apresentou a Casals, dizendo: "Maestro, aqui está um jovem violoncelista que gostaria de tocar como você, um dia". Ao que Casals respondeu: "Eu espero, entretanto, que ele venha a tocar como ele mesmo!" O autor então afirma que nunca se esqueceu desse desejo de Casals ${ }^{32}$.

Neste trabalho, esta pesquisadora acredita que, dentre esses cinco nomes, Mantel talvez seja o autor cuja obra é a de caráter mais objetivo, mais científico, pois se pauta

\footnotetext{
32 "Eisenberg was my first instructor, and I still remember the day he introduced me to Casals (I must have been about eight) saying, 'Maestro, here is a young cellist who would like to play like you someday.' To which Casals responded, 'I would hope, rather, that he will play like himself'. I have never forgotten this wish." $(1984$, p. 53)
} 
muito mais em aspectos físicos e motores para explicar o aprendizado musical no violoncelo, sem, contudo, descartar nem ignorar o lado artístico e psicológico, o que mostra que o autor tem um ponto de vista mais equilibrado, unindo os lados objetivo e subjetivo da execução musical, dentre os cinco distintos pontos de vista descritos.

Esta autora não pretende, entretanto, afirmar que esta seja a abordagem correta, somente afirma que esse é o ponto de vista mais geral dentre os cinco autores, que não contesta os outros pontos de vista, nem os nega, como sendo errados, mas, sim, que os integra.

Antes, porém, de fazer essa análise dos dados pesquisados, esta autora vê importância em abordar um aspecto fundamental do que será discutido a seguir, fazendo, para isso, uma breve descrição do assunto: a questão das Escolas violoncelísticas de técnica de arco, e também das diferentes maneiras de uso da mão esquerda, o que será realizado no item a seguir. 


\section{1. As escolas de técnica de arco e os diferentes tipos de posicionamento das mãos: um breve panorama}

Durante os mais de três anos de duração desta pesquisa, a maior dificuldade, para esta pesquisadora, foi, curiosamente, encontrar descrições dos tipos de Escolas de técnica do violoncelo. Esse tipo de conceito, abordado no dia-a-dia dos professores (observe que os três entrevistados, no Terceiro Capítulo, comentarão o assunto como sendo corriqueiro) e de muitos músicos profissionais, é muito mais bem definido no violino, encontrando-se muito maior quantidade de literatura que fundamente tais definições, porém encontra pouco espaço na literatura pesquisada sobre violoncelo.

Como é sabido e possível de se supor, devido ao maior histórico do violino como instrumento solista, a técnica desse instrumento foi inúmeras vezes adaptada pelos professores violoncelistas à técnica do violoncelo, e assim foram usados termos e definições semelhantes aos empregados no violino.

$\mathrm{Na}$ literatura encontrada para este trabalho somente foram definidas as Escolas do Violoncelo por Dmitry Markevitch (1984, p. 54), sem maiores explicações dos procedimentos por elas empregados (usando definições semelhantes às violinísticas):

- Escola Alemã, que derivou dos ensinamentos de Francesco Alborea, conhecido como "Franciscello" (1691-1739), posteriormente de Martin Berteau (1709-1771), depois por Jean-Pierre Duport (1741-1818), seguido de Jean-Louis Duport (1749-1819). Destes, originou-se a Escola Alemã, iniciada (segundo Markevitch) por J. J. Kriegck (1750-1813), depois por Justus J. F. Dotzauer (1783-1860), seguido por Karl Drechsler (1800-1873), Friedrich W. Grützmacher (1832-1903), Hugo Becker (1863-1941) e por Enrico Mainardi (1897-1976).

- Escola Inglesa, que derivou de Jean-Pierre Duport e se iniciou em seu aluno John Crosdill (1755-1825), seguido por Robert Lindley (1777-1855).

- Escola Francesa, que derivou de Martin Berteau, em seu aluno François Cupis (1732-1808), também com uma forte influência de Jean-Baptiste Bréval (1753-1823), que, pelo quadro, não foi aluno nem professor desses violoncelistas aqui apresentados. De François Cupis seguiu-se seu aluno Jean Levasseur (1765-1823), depois Louis 
Norblin (1781-1854), Auguste Franchomme (1808-1884), Jules Delsart (1844-1900), seguido por Paul Bazelaire (1886-1958).

- Escola Belga, da qual deriva, posteriormente a Escola Americana, e que é derivada de Jean Louis Duport, iniciada por seu aluno Nicolas Platel (1777-1835), seguido por Adrien Servais (1807-1866), e depois por Edouard Jacobs (1855-1925).

- Escola Americana, derivada do aluno de Edouard Jacobs, Felix Salmond (1888-1925);

- Escola Russa, que tem ramificações na Escola Alemã, com Dotzauer e Dreschsler, foi originada por um aluno de Karl Schuberth (1811-1863), que foi aluno de Dotzauer, Karl Davidov (1838-1889), e teve como representantes Alfred von Glehn (1858-1927), Alexandre Viergebilovitch (1849-1911), Julius Klengel (1859-1933) e também Hugo Becker, também integrante da Escola Alemã, Leopold Rostropovich (1892-1942), Gregor Piatgorsky (1903-1976), Emanuel Feuermann (1902-1942), Enrico Mainardi (também integrante da Escola Alemã) e Diran Alexanian (1881-1954), aluno de Grützmacher.

- Escola Húngara, derivada de um aluno de Dotzauer, Friedrich August Kummer (1797-1879), e posteriormente de seu aluno Julius Goltermann (1825-1876), é iniciada pelo aluno de Goltermann, David Popper (1881-1913).

Uma cópia desse quadro de derivações das Escolas e desses grandes professores de outros grandes professores, feito por Markevitch, pode ser observado com maior clareza no Anexo 3, ao final desta dissertação.

Contudo, este autor apresenta este quadro quase "genealógico" das "famílias" de grandes professores e suas heranças técnicas (de mestres para aprendizes), sem, infelizmente, conceituar ou dar bases bibliográficas mais sólidas para a explicação das diferenças entre essas escolas apresentadas.

Um dos conceitos tidos como senso comum a respeito dessas Escolas é o de que a Escola Russa se opõe à Escola Francesa (muitas vezes chamada de Franco-belga), no que diz respeito à maneira de uso do arco, principalmente. $\mathrm{O}$ arco, na Escola Russa, assim como foi bem explicado por Rostropovich, no Primeiro Capítulo, é segurado com o pulso mais baixo, alinhando o antebraço, o pulso e o dorso da mão, tomando o cuidado para não se levantar em demasia, com isso, o cotovelo. 
$\mathrm{Na}$ Escola Russa o polegar da mão direita é apoiado reto (mas nunca tenso), no vão circular formado no talão, pouco atrás do ponto de apoio empregado na Escola Francesa (que seria a esquina da noz do talão, com a unha roçando a madeira do arco). Aqui, o polegar é apoiado somente no talão, nesse seu círculo interno.

Com esses dois procedimentos é gerada uma maior sensação de facilidade para o apoio do peso do braço, pelo arco, na corda, e muito maior dificuldade com a flexibilidade do pulso e dos dedos, e, por conseguinte, maior dificuldade também de executar articulações menores e mais sutis.

Já na Escola Francesa (ou Franco-belga), ao contrário, há uma colocação do pulso mais alto que o antebraço e o dorso da mão (sem exageros e excessos de ângulos entre eles), e por essa razão as articulações mais sutis e menores são facilitadas, a velocidade de execução das articulações é também ajudada, bem como uma maior leveza de sons e de diferenças de timbres.

Contudo, pela mesma razão, a sonoridade perde em quantidade, e é muito mais difícil se tocar um forte ou um fortíssimo, e até mesmo um arco legato com grande magnitude sonora. O polegar é empregado na esquina da noz do talão, em geral levemente arredondado (pode ocorrer, muitas vezes, um jogo de movimentos, semelhante ao de uma dobradiça, ficando o polegar variando entre reto e arredondado, ou seja, dobrando e desdobrando as falanges do polegar, conforme a necessidade do arco, seu sobe e desce - mas isso depende de professor para professor, de instrumentista para instrumentista).

Em uma ou em outra escola, como é possível observar, perde-se por um lado e se ganha por outro. Sempre será uma escolha baseada tanto no que foi aprendido quanto no que foi experimentado, e essa escolha, como veremos no Terceiro Capítulo, sempre trará ganhos e perdas, além de ser uma escolha estética.

Para ter uma clara noção das diferenças sonoras entre essas duas escolas, sugerese aqui ouvir uma gravação de Mstislav Rostropovich ou de Gregor Piatgorsky, por exemplo (pertencentes à Escola Russa), e compará-la com uma gravação de uma mesma obra, realizada por Paul Tortelier ou Pierre Fournier, por exemplo (representantes da Escola Francesa). O que varia é o que se quer realçar, o que é mais importante esteticamente para cada escola, e também, obviamente, para cada intérprete. 
Já em relação à mão esquerda, existem também algumas maneiras de posicionála, e, aparentemente, independem das escolas mencionadas. Pode-se dizer, em princípio, que existem três posições básicas de mão esquerda na técnica do violoncelo, que são:

1. A posição fechada, empregada nas posições mais graves (meia posição, primeira, segunda, terceira, quarta e quinta), ou seja, a posição em que os dedos mantêm intervalos de meio em meio tom entre eles e em que o polegar fica atrás do braço do instrumento (ou mais na lateral, para as cordas mais graves);

2. A posição de extensão básica (pois existem diversos tipos de exceções de extensões, que dependem da ocasião e também da necessidade), na qual toda a posição de mão se assemelha à posição fechada, em todos os aspectos, exceto pelo fato de haver o intervalo de um tom entre o primeiro e o segundo dedos (a extensão mais fácil que a mão é capaz de realizar, devido à sua fisiologia e aos ligamentos entre os dedos).

3. A posição de chamada de "Capotasto" (em inglês, thumb position), que compreende todas as posições em que o polegar é colocado em cima do espelho, sobre as cordas (tanto tocando notas, quanto mudo, apenas posicionado). Esta posição deriva das posições mais graves, contudo é adaptada para se possibilitar o posicionamento do polegar em cima do espelho. O termo "Capotasto", como muitos termos musicais, vem do italiano e quer dizer "polegar sobre o espelho" (sendo capo=polegar e tasto=espelho).

Assim como nas posições de arco, também ocorrem variações dessas três posições

básicas, conforme os contextos e as necessidades. Podem ocorrer ocasiões em que sejam necessárias ou úteis extensões muito grandes, que exijam grande abertura entre dedos, que não são muito usuais. Pode ocorrer inclusive a necessidade de se fazer uso de posições muito fechadas e, aparentemente, "torcidas" (braço e antebraço posicionados muito mais para frente, por exemplo), com a finalidade de se tocar acordes ou trinados, por exemplo.

As três posições enumeradas acima são as mais usuais, porém a maneira como elas podem ser realizadas, ou seja, o uso dos dedos, da mão, do pulso, do cotovelo e do braço, como são aplicados, também pode variar. Por exemplo, existem duas formas mais comuns de se posicionar os dedos sobre o espelho do violoncelo, conforme já explicado por William Pleeth e Paul Tortelier, no Primeiro Capítulo, que são: 
1. A chamada "Posição Quadrada", em que há um maior equilíbrio no peso aplicado no espelho pelos dedos, principalmente entre o primeiro e o quarto dedos. Nessa posição, o segundo e o terceiro dedos têm uma inclinação de praticamente $90^{\circ} \mathrm{em}$ relação ao espelho, e, pode-se dizer, com muito cuidado e muitas ressalvas, que o primeiro dedo tem uma leve inclinação, em sua ponta, para o lado do segundo dedo, e o quarto dedo tem uma leve inclinação, também em sua ponta, para o lado do terceiro dedo. Além disso, a palma da mão é voltada para o lado do corpo do violoncelista.

Essa posição facilita uma abertura mais proporcional entre os dedos (facilitando uma afinação mais equilibrada), além de uma ágil movimentação do primeiro dedo, porém dificulta as extensões, e também dificulta uma movimentação mais ágil dos terceiro e quarto dedos, além da afinação do terceiro dedo, que tende a ficar muito mais baixa do que o necessário. Nessa posição, o polegar (nas posições mais graves) pode ser colocado atrás do segundo dedo, entre o primeiro e o segundo dedos, ou até mesmo atrás do primeiro dedo (o que facilita a agilidade do terceiro e quarto dedos, principalmente), dependendo da escolha do violoncelista.

2. A chamada "Posição Inclinada", em que todos os dedos são inclinados, num ângulo maior do que $90^{\circ}$, voltados para a direção do primeiro dedo. Nessa posição, os primeiros dedos são mais arredondados e o quarto dedo fica mais esticado, ou melhor dizendo, menos arredondado. Nessa posição, a palma da mão é levemente voltada para baixo (não tanto para o peito do violoncelista).

Essa posição facilita a execução de notas rápidas pelo terceiro e quarto dedos, por exemplo, em trinados, dificulta uma afinação equilibrada (pois os ângulos de abertura entre os dedos ficam mais desproporcional), e dificulta a movimentação mais ágil do primeiro dedo. Nessa posição, em geral, o polegar (nas posições graves) é colocado atrás do terceiro dedo, o que facilita a inclinação, ou atrás do segundo.

A escolha entre essas duas posições também se dá em função de muitos fatores, tais como: a Escola a que pertence(m) seu(s) mestre(s), escolhas físicas, tais como o tamanho das mãos do violoncelista, questões de conforto e também questões de escolha entre o que se prefere privilegiar, pois, como se pode observar novamente, qualquer escolha ajuda um aspecto e prejudica outro. 
3. Além dessas duas posições básicas, existem outros aspectos que modificam sutilmente o posicionamento dos dedos, tais como:

- a quantidade de contato dos dedos com o espelho, mais ou menos "carne", ou seja, com a "polpa" do dedo, ou mais com a "pontinha" dos dedos (ou seja, com a mão um pouco menos arredondada, ou um pouco mais arredondada - em que a primeira falange dos dedos fica quase $90^{\circ}$ com o espelho-, respectivamente).

- outro aspecto que pode alterar levemente a posição dos dedos é a colocação do polegar atrás do espelho, que também pode ser colocado mais reto, com a "carne", ou seja, a "polpa" da primeira falange em contato com o braço do violoncelo, ou então com o polegar arredondado e a "pontinha" direita interna (próxima à unha) do polegar apenas roçando o braço do instrumento. 


\section{2. Conceitos importantes discutidos ligados ao processo de aprendizagem e à interpretação}

Segue-se uma interpretação das idéias tratadas no Primeiro Capítulo:

\section{O estudo da técnica}

Em um ponto importante, relacionado com o estudo e o processo de aprendizagem, Tortelier e Rostropovich estão totalmente de acordo: para eles, o estudante de música e o músico devem ter uma incessante busca da superação de problemas técnicos. Devem também estudar esses problemas individualmente, como o faria um atleta (nas palavras do próprio Rostropovich), que treina seus músculos e movimentos separadamente para posteriormente treiná-los no conjunto de sua especialidade esportiva: a mentalidade implícita nesta idéia é a da "superação de debilidades".

Essa é uma idéia vista por Mantel como útil, mas, para ele, é necessário que se tenha sempre a atenção de que se está treinando algo técnico, que será aplicado na música: ou seja, que não se esqueça a razão final desse estudo. Apesar disso, o autor admite ser possível separar a parte técnica da artística e emocional, no ato do estudo, com fins práticos e aplicáveis, embora também seja necessário estar atento para não estressar fisicamente o corpo, em busca dessa "superação de deficiências". Mantel, além disso, também acredita que uma técnica deficiente corrompe o resultado sonoro, interferindo em seus resultados, mesmo em um músico criativo.

Pleeth é categoricamente contra essa prática incessante em busca da perfeição técnica e afirma que jamais o estudante ou músico deve estudar simplesmente exercícios de técnica sem a finalidade musical (ainda que afirme que os exercícios técnicos podem ser transformados em uma prática musical e não simplesmente técnica, ou seja, podem ser vistos muito além de técnica isolada). Pleeth também crê, apesar dessas ressavalvas, que as pessoas normalmente estudam técnica em quantidade insuficiente.

William Pleeth aponta que a prática isolada de técnica pode viciar o intérprete em estar sempre com suas preocupações voltadas apenas a problemas puramente técnicos, esquecendo-se, dessa forma, dos problemas musicais e interpretativos. Ou seja, para Pleeth tal prática, proposta e "sacramentada" por Rostropovich e Tortelier, 
pode transformar o aprendiz, em longo prazo, apenas em um bom instrumentista, nunca em um artista e intérprete.

Sobre este mesmo assunto, Sazer afirma que se deve sempre buscar a prática desassociada da dor (ou seja, exercícios sempre devem ser feitos sob a atenção da percepção corporal e muscular, nunca de maneira indiscriminada e incansável), ou seja, trabalhar exercícios de técnica deve ser trabalhar também percepção corporal e muscular, inclusive, e principalmente, quando se almeja superar problemas técnicos. $\mathrm{O}$ estudo, para ele, nunca deve ser associado a sofrimento ou a abnegação, mas sim a integração do corpo e da mente. Mas, nesse caso, Sazer também não aborda as emoções e idéias individuais do intérprete, e dessa forma, apesar de se opor a Rostropovich e a Tortelier, sobre a individualidade de cada instrumentista - como indivíduo e artista - não apresenta um ponto de vista.

Pleeth e Sazer concordam que é errado tratar o estudo (e isso é comumente aplicado por profissionais e por estudantes) como uma luta contra o violoncelo e até mesmo contra o próprio músico, e que essa forma de pensamento, em si, carrega uma grande carga de tensão e culpa, altamente prejudiciais a uma performance fisicamente eficiente (Sazer) e artística (Pleeth).

Ou seja, a idéia conciliadora dessas cinco visões, não necessariamente a mais correta ou eficiente, é a de Mantel, que admite a possibilidade de separar corpo-menteemoção para fins práticos específicos de estudo de problemas de técnica, sem negar ou deixar de lado outros aspectos.

A respeito desse ponto, a autora Julie Lyonn Lieberman, em seu livro You are your instrument - The definitive musician's guide to practice and performance (Op. cit., 1991) (Você é seu instrumento - o guia definitivo dos músicos para a prática e a performance), afirma que as demandas de uma faminta tecnologia em busca das notas perfeitas, as idolatrias da mídia aos prodígios e aos músicos-celebridades, além da competição por empregos e status limitados a poucos privilegiados, aumentam as pressões nos músicos e estudantes. Além disso, essa autora ainda aborda uma excessiva supervalorização da técnica, dos movimentos físicos mecanicamente corretos, treinamento do ouvido, teoria e repertório, em detrimento do equilíbrio na busca de todos esses aspectos, além do funcionamento correto de seus corpos, abordagens que poderiam lhes proporcionar uma carreira mais longa e mais saudável. 
Essa autora também acredita que quando há uma consciência do uso do corpo e quando se aumenta a qualidade da experiência do estudo e da performance, há um ganho de qualidade não somente na saúde do intérprete, mas também na qualidade do som, pois a tensão muscular reduz a firmeza e a fluência, a afinação decai, assim como decai a possibilidade de velocidade, perdida em esforços inúteis.

Julie Lieberman diz ainda que o conceito de "no pain, no gain" ("sem dor, sem ganhos", ou "não há ganho sem dor") não é mais uma idéia válida, pois hoje, com o desenvolvimento da Music Medicine e das idéias de união corpo-mente-espírito mais valorizadas, o músico precisa buscar qualidade de experiência, bem como um papel ativo em ter responsabilidade por sua saúde. Para se fazer música bela, segundo Lieberman, é necessária uma participação totalmente ativa do corpo: livre de dor, graciosamente e fluidamente livre. (Op. cit., pp. IX- XX)

Nesse mesmo livro, no prefácio, o médico W. Donald Cooke concorda que as qualidades "atléticas" exigidas dos músicos podem muitas vezes conduzir às lesões e que os músicos precisam entender como as várias partes de seus corpos trabalham em conjunto, além de aprender a tirar vantagem da maravilhosa inter-relação dos músculos, ossos e nervos que agem em conjunto para produzir a música. Ou seja, o autoconhecimento, a percepção corporal e o conhecimento da físiologia do corpo são absolutamente necessários para se evitar lesões e levar a uma performance com excelentes resultados e pouco esforço físico.

Marco Antônio Lavigne e Paulo Gustavo Bosísio, também sobre esse assunto, em seu livro ainda não publicado Técnicas fundamentais de arco para violino e viola (Op. cit., 1999, contam que Carl Flesh, no início de sua mais importante obra, que é intitulada $A$ arte de Tocar Violino, estabelece:

\footnotetext{
“(...) para ser um bom executante, o violinista deve dominar três áreas estreitamente relacionadas. A primeira seria a técnica geral, que envolve a completa formação mecânica de ambos os braços (...)" para "conseguir executar todos os efeitos sonoros requisitados pelo repertório; a segunda, a técnica aplicada, consistiria no desenvolvimento da capacidade de resolver racionalmente eventuais dificuldades técnicas surgidas ao longo de determinada composição; finalmente a concepção artística, que pressupõe uma total liberdade de espírito, adquirida através do domínio dos aspectos mecânicos e que permite ao intérprete expressar-se artisticamente por meio de seu instrumento. (...)" (1999, p. 3- 4)
} 
Esses dois autores ainda mostram que esse modelo teórico dá origem a um método de estudo que se subdivide em quatro blocos de trabalho diário, que são: mecânica (que consistiria no estudo de técnicas de mão e braço esquerdos, técnicas de arco e da coordenação destes, em conjunto), escalas, estudo e repertório.

Observa-se, comparando com os textos anteriormente pesquisados, que William Pleeth e Carl Flesch discordam a respeito do lado artístico, pois, aparentemente, para Flesch a concepção artística só pode ser obtida posteriormente ao desenvolvimento e amadurecimento das capacidades técnicas do músico, e para Pleeth ele deve ser estimulado, como vimos, sempre e desde a primeira aula. A idéia de "conceito-meta", concebida e exposta por Mantel também vai de encontro com essas idéias de Flesch, já que Mantel afirma que a habilidade técnica só poderá ser obtida se houver por trás uma concepção apurada do que se deseja obter, e essa concepção já é, na visão desta pesquisadora, também, um conceito artístico.

Para qualquer instrumentista, contudo, é muito claro e fácil notar que as capacidades de concepções musicais e sonoras de um indivíduo estão sempre à frente das capacidades técnicas. É possível também arriscar a hipótese de que as concepções artísticas também vão se aperfeiçoando e se tornando cada vez mais detalhistas e apuradas, à medida que as capacidades técnicas vão sendo desenvolvidas. Contudo, a técnica que o músico realiza está sempre aquém (às vezes muitíssimo aquém) das suas reais capacidades técnicas (que são sempre infinitas e impossíveis de se prever), o que provoca, muitas vezes, frustração, desistências e até mesmo tensões, que vêm a prejudicar ainda mais a qualidade da execução (tanto no lado técnico quanto artístico).

Outro conceito citado tanto por Tortelier quanto por Mantel é o de que o músico deve, por meio do estudo e do aperfeiçoamento das habilidades técnicas e da percepção corporal, chegar a um controle que lhe permita ter força e flexibilidade, enquanto que Rostropovich e Pleeth não mencionam esses dois aspectos em conjunto, e Sazer parece tratar somente do aspecto da flexibilidade, e, aparentemente tem ressalvas quanto à idéia de treinar a força, estando voltado muito mais às aplicações dos conceitos de peso e equilíbrio.

Sobre o desenvolvimento e aperfeiçoamento técnico, Shinichi Suzuki, o criador do mundialmente conhecido e utilizado "Método Suzuki", em seu livro Nurtured by Love (Op. cit., 1994) (Nutrido pelo amor), afirma que a pessoa deve despender de 
grande esforço em se aperfeiçoar, pois acredita que pensar que nascemos com uma habilidade que se desenvolve por si mesma é um erro. Afirma que se algumas habilidades são fáceis para uma pessoa, isso é evidência de que essas habilidades foram desenvolvidas por treinamento, em tal proporção que já a tornaram parte desta pessoa. E ele insiste que o "tornar parte de você" é sinal que seu propósito foi atingido, por trabalho e repetição, até que a habilidade crie bases em seu inconsciente ${ }^{33}$.

\section{A prática rotineira}

Sobre a prática rotineira, novamente uma mentalidade "correta" da prática é discutida: Rostropovich e Tortelier concordam que é preciso ter disciplina, repetições exaustivas, e rotina, e Pleeth e Sazer são contra essa mesma idéia: para Pleeth, a prática deve ser criativa, deve se desenvolver dia-a-dia, ao contrário de uma busca de repetições que sempre estejam girando em torno das mesmas bases técnicas, chamadas por ele de uma busca fanática por uma segurança, que luta contra o medo de falhar. Acredita que esse mesmo posicionamento frente à música gera ainda mais insegurança e falhas, além de crer que o medo é resultado também de uma "atitude técnica" exagerada.

Contudo, Rostropovich também afirmou que se deve sentar para estudar com um roteiro planejado de estudos, para que não se esqueça nunca das músicas, dos estudos, das escalas, das partes de orquestra, de música de câmara entre outras, tanto para diversificar o estudo e atingir diversas áreas, como também com o intuito de que não se evite estudar aquilo que o indivíduo mais precisa estudar, mas que evita fazer, devido à suas dificuldades.

Mantel também, aparentemente, concorda com esse ponto ao afirmar que não se deve praticar sem uma idéia acurada do que se está estudando. Note que esta afirmação trata de um mesmo assunto, em linhas gerais, porém trata também de um ponto específico: ao se estudar alguma música, trecho, escala, estudo ou o que quer que seja, além de se buscar essa diversificação do estudo, deve-se ter claramente a noção do que se está estudando, naquele momento, com aquele estudo. Por exemplo, se seria afinação, fraseado, igualdade das notas, memória, qualidade de som, timbre ou o que o

\footnotetext{
33 "Expend effort on improving yourself. To think that you are born with an ability that develops by itself is a mistake. If some skill is easy for you, that is evidence that it has become a part of you. 'Become a part of you' is to say that your purpose has been achieved by work and repetition until the skill has firmly taken hold in your consciousness." (1994, p. 44).
} 
indivíduo se propuser. Mantel acredita que se o estudo for desprovido desse tipo de motivação e também de consciência, ele representa apenas uma perda de tempo.

Mantel trata desse ponto logo no início de seu livro, afirmando que as tensões espelham os efeitos de esperança e desapontamento, mas, por outro lado, afirma que as demandas musicais não poderão ser executadas a menos que os músculos estejam treinados para estarem prontos para executar com precisão os movimentos desejados.

\section{O relaxamento}

Um ponto de comum acordo, em todos os autores, é a questão do relaxamento que é tido como absolutamente necessário para uma boa performance, lembrando, obviamente, que não existe relaxamento completo, visto que para qualquer ação, ou mesmo manutenção de postura existe um trabalho muscular, que deve estar ligado à firmeza, e não à tensão.

Apenas a título de ilustração, é um dado relevante acrescentar que Rostropovich afirmou, nas aulas dadas a esta pesquisadora, que "se a pessoa estiver confortável e estiver afinado, está bom". Em uma das cartas dirigidas a ela, posterior às aulas dadas, também pede a esta aluna que tome sempre muito cuidado para não sobrecarregar a mão esquerda em seus estudos.

O Prof. Robert Suetholz (que será entrevistado no Terceiro Capítulo), em seu artigo "Aspectos da técnica violoncelística da mão esquerda" (Op. cit., 1999), cita Ivan Galamian, que escreveu: "a relação do instrumento com o corpo, braços e mãos deve ser tal que permita que todos os movimentos sejam confortáveis e eficientes durante a execução" (1999, p. 5).

Este ponto, no entanto, parece ser o pilar das idéias expostas por Sazer em seu livro: uma constante busca, não exatamente do relaxamento ao se tocar, mas do conforto: de um tocar livre de dor (leia-se, também, livre de sofrimento). No livro, já citado, de Julie Lieberman, You are your instrument, a autora também concorda que a dor deve ser vista como um valoroso sinal que, se for percebido corretamente, pode impedir que o músico abuse de seu corpo e que se dê conta de onde e como este abuso está sendo cometido.

Uma recomendação que normalmente é feita, em aulas, por professores, deve ser vista com cautela: “Doeu, parou!” Note que esta recomendação pode ser levada ao "pé 
da letra" pelo aluno, dando a entender que é necessário (ou até mesmo desejável!) que se estude determinado exercício até doer, e somente então se deve parar de estudar. Esse entendimento é totalmente condenável. Entender a dor como um alerta pode ser muito importante, mas buscar chegar até ela, como meta, é um grande erro.

Jeffrey Irvine, em seu artigo "Avoiding and recovering from bow arm and upper torso injuries" (Evitando e se recuperando de lesões no braço do arco e na parte superior do tronco), publicado na revista American String Teacher (Op. cit., 1988, p. 65), dá idéias simples, porém úteis em se tratando da dor: acredita que se algo dói, devemos parar de tocar, a menos que estejamos em um concerto. Depois recomenda que deixemos a dor ir embora antes de começar a tocar de novo. Além disso, recomenda que, se a dor durar por mais de alguns dias, devemos pensar em visitar algum médico especialista em problemas de músicos. Parecem recomendações banais, contudo, essa atenção e essa ação preventiva, muitas vezes, não são realizadas.

Tortelier, no entanto, parece se opor a esse conceito, pelo menos em seu livro aqui tratado, ainda que não se possa afirmar com veemência que essas são suas idéias pessoais sobre o violoncelo. Descreve que o que caracteriza as boas escolas de interpretação violoncelística é o desenvolvimento de algumas qualidades, tais como caráter, gentileza, firmeza, flexibilidade; contudo afirma que nenhuma dessas qualidades surge comodamente, nem ao menos nas pessoas de maior talento. E declara, como já foi exposto no Primeiro Capítulo, que se deve lutar contra as debilidades naturais constantemente. Note-se que Tortelier não diz "aperfeiçoar" qualidades, ou outro termo semelhante, mas sim "lutar" contra debilidades, e o verbo "lutar" mostra que o estudo se opõe, em sua concepção, ao relaxamento e à comodidade.

Mantel, como já mencionado, falando do relaxamento, afirma que a tensão física e o desapontamento gerado pelos resultados que ela proporciona fazem decair o rendimento artístico. Trata também de fato importante, não lembrado pelos outros autores: o excesso de tensão e um excessivo acúmulo de esforço e treino, que almejem sempre ultrapassar os limites em que o corpo se encontra, também podem fazer decair o rendimento artístico. Por isso ele diz que deve haver um "estoque" de energia, que está sempre menor em músculos estressados. Esse autor lembra ainda que o músico deve treinar muito mais a coordenação motora do que a resistência muscular. 
Em artigo intitulado "Overuse Injuries" (o que aqui é comumente denominado "Lesões por esforço repetitivo", chamado LER), publicado na revista American String Teacher (Op. cit., 1988), o Dr. Richard Norris, citado por Sazer, também aborda essa questão de músculos com um "condicionamento físico inadequado". Ele descreve que músculos tensos, fracos ou que não estejam alongados adequadamente, ao serem exercitados, são mais suscetíveis às lesões do que músculos fortes e flexíveis. E afirma que o condicionamento físico e a educação física sempre foram negligenciados nas escolas de música e conservatórios, prevendo que a atenção para a importância do condicionamento físico e dos exercícios para músicos deve crescer nos próximos anos. (1988, p. 45)

Pleeth concorda com essas idéias, tanto de Mantel quanto de Norris, ao dizer que o corpo deve estar treinado, mas que, na hora da execução, o corpo deve ser esquecido, e quanto mais em contato com os sentimentos e a concepção artística da obra o músico estiver na hora da performance, melhor esta será, e para isso acaba exemplificando casos ocorridos com seus alunos. Também concorda com Mantel e Sazer, quando lembra que, hoje em dia, o que é valorizado é se o som é forte e se são tocadas muitas notas rapidamente, ou seja, um tratamento do artista como se fosse um atleta: são valorizados a rapidez e o volume de som e ignoradas as suas qualidades artísticas individuais, o que ele condena.

Contudo, não se deve esquecer que Rostropovich falou que "o músico deve trabalhar como um atleta", exatamente a frase condenada no parágrafo anterior. O Prof. Robert Suetholz, em artigo já citado, concorda com Rostropovich declarando: "Músicos são atletas e, portanto, a posição e a postura assumidas devem permitir respiração e liberdade de movimentos, totalmente desimpedidas, eliminando uma grande fonte de tensão.” (Op. cit., 1999, p. 5)

\section{O estudo com profundidade}

Outra idéia, apresentada por quatro violoncelistas, Rostropovich, Tortelier, Mantel e Pleeth, é a de que, ao se estudar um exercício de técnica, deve-se sempre estudá-lo criativamente, com o máximo de paciência e profundidade possível, sempre buscando o sentido musical dos mesmos. Deve-se, segundo eles, buscar aprender música, aprender a tocar o instrumento, que é o mais importante fim que se encontra por 
detrás de um simples exercício, e que não seja apenas um meio de aprender um determinado golpe de arco, uma determinada mudança de posição, ou passagem musical. Ou seja, deve-se pensá-lo sempre musicalmente, criativamente. Pleeth afirma até mesmo que se deve inventar sobre um único exercício e refletir sobre os inúmeros aspectos musicais que ainda podem ser aprendidos nele.

Christopher Bunting, em seu livro Essay on the craft of cello palying, vol.2 The left hand (Op. cit., 1982, p. 5) (que poderia ser traduzido como Ensaio sobre a habilidade, ou a arte, de tocar violoncelo, vol. 2 - A mão esquerda), afirmando a idéia de estudar com profundidade proposta pelos autores, diz que o violoncelista deve parar de "tentar", e sim estudar todo o mecanismo psicofísico envolvido. E diz ainda que não exagera ao afirmar que anos podem ser poupados desta forma ${ }^{34}$.

Ainda há outro aspecto de concordância entre Tortelier e Sazer: os exercícios não devem levar a execução à perfeição, apenas, senão buscar um ótimo resultado obtido com o mínimo de esforço (ainda que Tortelier deixe claro que para ele, até que se chegue neste resultado de pouco esforço e ótimo desempenho, é necessário um grande esforço, por muito tempo).

Schnichi Suzuki, em seu livro já citado Nurtured by Love (Op. cit., 1994), também propõe idéia semelhante, muito radical e surpreendente. Afirma que, para que uma pessoa venha a tocar de maneira fluente e razoável, deve-se estudar com grande empenho, por pelo menos dez anos seguidos, pois acredita que dez anos de esforço podem transformar inferioridade em talento superior (1994, p. 40), como ele descreve: "sem pressa e sem descanso". (1994, p. 45)

A autora Madeline Bruser, em seu peculiar livro The art of practicing - A guide to making music from the heart (Op. cit., 1997) (que poderia ser traduzido por $A$ arte da prática - Um guia para fazer música proveniente do coração), diz que o valor de um exercício depende também de nosso estado de espírito, pois ela pensa que se nós não o achamos interessante, ele se torna inútil (1997, p. 17).

\footnotetext{
34 "Stop 'trying' and study the whole psychophysical mechanism. I do not exaggerate when I say that year may be saved in this way" (Op. cit., p. 5)
} 


\subsection{Conceitos técnicos importantes discutidos}

\section{Alteração de padrões musculares}

Um dos pontos de convergência entre os violoncelistas é o de que a mínima alteração num padrão muscular, feita em exercícios repetitivos, ou trechos musicais repetitivos, já propicia um alívio imediato e importante para o corpo, pois altera totalmente o conjunto de músculos envolvidos. Essa opinião é repetida por Sazer, Rostropovich e Mantel.

Sobre os movimentos, como um todo, uma idéia também é apontada tanto por Sazer como por Pleeth: a de que não existem movimentos corporais retos numa execução musical, principalmente em se tratando de movimentos de arcadas. Sazer apresenta ainda desenhos de movimentos do braço, pulso ou arco que acabam acontecendo em movimentos de arcadas, tentando reproduzir o "desenho" feito por eles nesses movimentos, e os representa como círculos grandes ou pequenos, ovais e espirais, afirmando que o vai e vem de arcadas sempre produz movimentos corporais redondos.

Pode-se até arriscar que Mantel também compartilha dessa idéia, ao dizer que jamais usamos os mesmos músculos para repetir determinados movimentos, o que leva à reflexão imediata de que o movimento "reto" do sobe e desce das arcadas é visualmente parecido, repetitivo, mas que por envolver sempre conjuntos de músculos diferentes, sempre é um movimento diverso do corpo e apenas dá a impressão de seguir uma linha reta.

Diran Alexanian, em seu livro Complete Cello Technique - The Classic Treatise on Cello Theory and Practice (Op. cit., 2003, p. 21- 36), concorda plenamente com essa idéia dos movimentos circulares feitos pelo braço do arco, desenhando até mesmo o exato movimento circular feito pelo arco, tanto nos arcos "para cima" quanto nos arcos "para baixo" e em mudanças de cordas, em diversos de seus exercício propostos.

\section{O Polegar}

Sobre o polegar, Sazer afirma que, sempre que possível, devemos liberá-lo, idéia que é absolutamente contestada por Paul Tortelier. Esse último é contundente ao afirmar que o posicionamento correto do polegar é sua colocação firme (note-se, entretanto, que ele não quer dizer "fixa") atrás do espelho, e sempre atrás do segundo dedo, tanto em 
posições fechadas quanto nas extensões. $\mathrm{O}$ autor afirma que esse posicionamento é fundamental para a boa afinação e uma firme sensação de posicionamento de todos os dedos, individualmente, e da mão toda, particularmente. No entanto, Sazer afirma que a liberação do polegar traz uma grande sensação de liberdade à mão esquerda.

Qual posicionamento seria correto? Poderia se pensar que a mão deve se adaptar em diferentes ocasiões, ou que algum posicionamento estaria errado? Num estudo individual, talvez se chegue à conclusão de que uma das duas idéias esteja correta e outra errada, ou até mesmo que se possa fazer uso de diferentes maneiras de pensar, em diferentes contextos. Em trinados, por exemplo, é muito perceptível que a liberação do polegar traz mais velocidade e coordenação para esses movimentos, visto que, dessa maneira, os ligamentos e músculos dos dedos estão mais distanciados, abertos e relaxados.

Já em mudanças de posição, por exemplo, pode-se notar que deixar o polegar posicionado atrás do segundo dedo, ou posicionado atrás do braço, como entre o segundo e o primeiro, ou até mesmo atrás do terceiro (dependendo da idéia de "forma de mão" escolhida), ou seja, uma posição relativamente firme (não fixa) pode ajudar a afinar melhor a posição em que se chegou, e até mesmo mudar de posição com maior precisão.

Sobre esse assunto, o Prof. Suetholz, no artigo citado anteriormente, ainda acrescenta:

"É preciso notar que o polegar pode mudar freqüentemente de posição, mesmo na primeira posição. Enquanto se utiliza dedos individuais, na hora de vibrar, por exemplo, o polegar pode (e deve) se movimentar para uma posição que sustente cada dedo (...)." (1999, p. 14)

\section{A forma de mão}

Apesar de defender a forma inclinada em detrimento da quadrada, Pleeth acredita que uma forma de mão "correta", pré-moldada, é prejudicial à liberdade de movimentos da mão esquerda, e que este conceito prejudica inclusive as respostas emocionais e musicais que os músculos das mãos podem ter aos sentimentos e sensações de um intérprete. Para ele, esse conceito ainda prejudica uma afinação que possa se adaptar às exigências harmônicas, ou prejudica até mesmo pequenos ajustes feitos pelo ouvido do intérprete. O autor pensa também que os músicos que empregam 
esse conceito acreditam falsamente que estão afinados, já que seus dedos estão abertos e posicionados dentro desse conceito de forma afinada, e acabam não utilizando os ouvidos, e sim uma sensação física e tátil para afinarem notas e intervalos.

Rostropovich (tendo esta pesquisadora utilizado aqui, como base, apenas as aulas que the foram dadas pelo violoncelista, além da observação de suas execuções) parece apoiar essa idéia, já que, perguntado sobre a posição correta da mão esquerda, apenas respondeu o seguinte conceito: "Se estiver confortável e afinado, está bom”. Parece um conceito simples, até mesmo simplista, mas o que seria uma posição que uniria uma correta afinação e o conforto? Essa é uma pergunta a ser pensada na prática diária e em cada execução de uma peça; o conceito é claro, mas também é claro que não é tarefa simples atingir esses resultados por ele propostos.

Sazer concorda com esses conceitos, e afirma que sempre se deve buscar o conforto, tratando inclusive dessa idéia de maneira ainda mais firme quando fala de extensões. Diz que a mão só pode se mover livremente quando totalmente livre de tensões. Também é contra o posicionamento prévio dos dedos, que muitas vezes é ensinado a ser percebido pelos iniciantes por meio de fitas adesivas sobre os intervalos das posições (em geral, os intervalos da primeira posição), prática que foi defendida e consagrada pelo Método Suzuki. Sazer acredita que essa prática faz mais mal do que bem, já que induz os estudantes a segurem a forma da mão sempre aberta e posicionada sobre as notas, com os dedos afastados, de maneira tensa. Também acredita que, dessa forma, o aluno fica treinado a confiar mais em seu corpo do que em seus ouvidos.

Contudo, esse autor também aponta para o fato de que esse posicionamento da mão deve ser diferente em passagens rápidas e lentas, e que nas rápidas a mão deve ter os dedos mais arredondados, bem como a mão e o braço devem estar alinhados, numa posição mais neutra, para que todas as notas sejam alcançadas com maior rapidez, já que os dedos têm tamanhos diferentes. Já nas passagens lentas, Sazer acredita que há mais tempo para adaptar a mão e os dedos a cada nota e intervalo. $\mathrm{O}$ autor ainda deixa claro que uma única posição de mão não poderá prover o melhor equilíbrio e suporte necessário para cada dedo, devido às suas diferenças de posicionamento na mão e a seus diferentes tamanhos e forças.

Tortelier, por outro lado, se posiciona de maneira distinta da dos demais autores: define uma posição exata das mãos, inclusive como cada dedo deve estar em contato 
com o espelho, ilustrando a idéia com fotos. Para ele, o segundo e o terceiro dedos devem estar posicionados retos, em relação ao espelho, e o indicador com a primeira articulação levemente voltada para dentro, para o lado do segundo dedo, assim como o quarto dedo, com a primeira articulação levemente voltada para dentro, para o lado do terceiro dedo.

Os dedos devem, ainda, estar com as duas primeiras articulações levemente recolhidas, de modo a arredondar a mão, tomando cuidado para não deixar que as unhas fiquem em contato com o espelho. O polegar deve estar sempre redondo, posicionado roçando o espelho, exatamente atrás do local onde se encontra o segundo dedo, inclusive nas extensões.

Tortelier ainda enfatiza que os dedos devem cair sobre as cordas verticalmente, e que o pulso deve estar levemente arqueado para cima, nunca "afundado" para baixo. E propõe, além disso, um exercício intitulado "Exercício para evitar a natural, mas incorreta tendência da mão de se inclinar para trás" (1993, p. 94), que vai contra as idéias da forma de mão inclinada, e caracteriza-a como natural, mas incorreta, e não como uma outra opção a ser utilizada, outra escolha a ser avaliada, nem mesmo dando crédito a esta idéia como sendo uma alternativa em determinadas situações.

Note-se que Sazer, Mantel e Rostropovich sempre afirmam defender a busca do movimento "natural" como sendo o movimento correto.

Em livro já citado de Margaret Campbell, a autora menciona uma citação de Richard Markson, que foi por seis anos aluno de Tortelier. Richard declara que, já na primeira lição, Tortelier, mostrando o espaço do espelho, afirmou que este lugar permite uma posição lógica para a mão e que todos os dedos devem ser iguais. Disse ainda que estava certo de que a posição quadrada, dando créditos a Casals por essa abordagem, contribuiu grandemente para a clareza dessa técnica.

É importante citar também, a título de curiosidade, que Diran Alexanian, Christopher Bunting e também Suzuki, em seus métodos-livros citados na Bibliografia, também posicionam a mão da maneira quadrada, ao menos nas posições mais graves (já que parece claro que essa posição vai ficando cada vez mais difícil de ser feita nas posições agudas, parecendo muito mais com a posição inclinada), mas que a informação que nos interessa aqui é que eles afirmam que essa é a forma correta, e esse tipo de 
afirmação subentende que outras formas estão erradas, sem explicar razões para a escolha desse tipo de "forma de mão".

É da opinião desta pesquisadora que a prática do aprendizado da primeira posição por meio da colocação das fitas adesivas, difundida por Suzuki, bem como as fotos de demonstração em seus métodos, pelo menos no que diz respeito ao violoncelo, parece sacramentar a posição quadrada e previamente aberta e determinada da mão esquerda, proposta por Tortelier, já que na posição inclinada fica mais difícil manter aberturas muito semelhantes entre cada dedo, parecendo a esta pesquisadora, nesse caso, mais prudente que cada intervalo seja adaptado um por um, não mais pelo distanciamento dos dedos, e sim pela afinação em si.

O Prof. Suetholz, em artigo citado, afirma:

\begin{abstract}
"Também há opiniões conflitantes quanto à quantidade de dedos que devem estar em contato com as cordas ao mesmo tempo. Alguns especialistas afirmam que apenas um dos dedos deve se colocar sobre a corda, com o peso sendo transferido suavemente para o dedo seguinte enquanto o primeiro se afasta da corda. Outros, como Duport, recomendam que se divida a pressão entre dois ou mais dedos, enquanto outros ainda adotam o ponto de vista lógico de que é preferível adotar uma atitude que se situe entre os dois extremos." (1999, p. 9)
\end{abstract}

Sobre as posições, quadrada ou inclinada (aqui também chamada de perpendicular), ele acrescenta uma citação de Janos Starker, alegando que foi este último quem descreveu melhor as diferenças entre elas. Starker diz:

"Há duas correntes de pensamento sobre a questão da posição inclinada ou perpendicular. Com a posição inclinada usa-se mais a ponta do dedo. Com a posição perpendicular, é a parte mais carnuda do dedo que entra em contato com a corda, resultando em menor precisão. (...) A vantagem da posição inclinada da mão é o ângulo da mão para tocar em qualquer área do instrumento.” (Op. cit., p. 10)

Não se está afirmando que uma idéia esteja mais correta, em detrimento da outra, mas sim que, nesse caso específico e isolado, a forma quadrada previamente posicionada pode induzir a que o músico tenda a não buscar por uma afinação mais consciente por meio de seu ouvido, buscando-a de maneira mais automática, em relação à posição de seu corpo, ainda que essa afinação possa vir a ser muito boa, por ter intervalos bem regulares. No entanto, sabendo dessa tendência à automação e a uma ausência de "ouvido crítico", ainda que concordando com a forma quadrada, o mesmo músico pode evitar o automatismo e buscar a afinação por seu ouvido e pelas relações 
harmônicas e melódicas da música ou exercício em questão, tanto em seu estudo como na execução.

\section{Formas de se sentar ao instrumento}

O violoncelista Tortelier, sobre esse tópico, afirma que a cadeira deve estar posicionada segundo o tamanho das pernas do executante, que o assento deve ser plano, os pés bem separados e as plantas dos pés bem apoiadas no chão. Há, nessa idéia, um pequeno ponto de discordância de Sazer com Tortelier: este último acredita que o assento deve ser plano, e Sazer acredita que o assento deve estar mais alto e até mesmo levemente inclinado, de modo que a parte de trás do assento fique mais alta do que a da frente, a fim de que a parte superior da perna não forme um ângulo de $90^{\circ} \mathrm{com}$ relação à sua parte inferior, ou seja, que esse ângulo seja maior que $90^{\circ}$. Nos outros itens, relacionados às plantas dos pés bem apoiadas no solo, e aos pés estarem bem separados, os dois autores estão de pleno acordo.

Também em relação a esse tópico, é curioso que Tortelier afirma que o encosto deve ser mais firme que macio, e Sazer sugere até mesmo que o violoncelista tenha uma almofada que torne o assento mais alto e mantenha o ângulo da perna maior que $90^{\circ}$, e que a leve consigo, principalmente para utilizá-la quando for tocar em locais em que cadeiras não apropriadas são disponibilizadas, a fim de diminuir possíveis desconfortos lombares.

Os dois autores concordam, porém, que o violoncelo deve ser posicionado mais à esquerda do executante e não centralizado, posição que, como dito anteriormente, já era utilizada por Duport (o que é mostrado em pintura, no livro de Sazer). Esta idéia é ilustrada por ambos autores com fotos e desenhos, e facilita, segundo os dois, a liberdade dos movimentos do braço direito e também do esquerdo, na execução.

Porém, mais dois pontos de extrema discordância entre esses dois autores são a posição da cabeça e dos ombros: Sazer emprega idéias mais ligadas às técnicas voltadas à correção postural, em que o pescoço deve estar reto com relação à coluna e a cabeça não deve estar inclinada para frente, nem os ombros, senão posicionada de modo que o topo da cabeça esteja voltado para cima, e o queixo levemente apontado para baixo; Tortelier, no entanto, diz que a cabeça e os ombros devem ser posicionados retos, ou 
levemente inclinados para frente. Acredita ainda que, ao se tocar em posições mais altas (agudas), deve-se acentuar essa inclinação para frente.

Tortelier afirma também que em instrumentistas de braços curtos, a inclinação do ombro direito e do torso para frente deve ser acentuada, o que, em tese, faria o músico sair de seu eixo de equilíbrio perfeito, tanto de quadril, quanto de tronco (pelo ponto de vista de Sazer). Na mesma linha de pensamento, também acredita que os músicos de braços longos devem posicionar seus ombros mais para trás. $\mathrm{O}$ equilíbrio de eixo do corpo, de peso e da coluna ereta, para Sazer, embora deva ocorrer sempre com mobilidade, não deve ser nunca perdido de vista, e ombros nunca devem ser deslocados para frente.

Sobre as técnicas posturais, sem adentrar em detalhes ligados à medicina ou à educação física (que esta pesquisadora não teria a condição de fazer com profundidade, pois não é sua área de pesquisa), a título de exemplo, pode-se falar brevemente da maneira ideal de se sentar, buscada em outras técnicas ligadas ao corpo, como na prática da Meditação ou na prática da Ioga (da qual esta pesquisadora é praticante há pelo menos dez anos, tendo sido, por cinco anos, orientada pelo Prof. Marcos Rojo Rodriguez [CEPEUSP -USP]). Na prática da Meditação e da Ioga defende-se que pescoço e coluna devem se manter em linha reta, amparando as idéias de Sazer, com o topo da cabeça voltada para cima e o queixo levemente voltado para baixo, sem deslocar ombros para frente ou para trás, pois essa seria a posição em que o tronco fica ereto com o menor esforço possível.

Mantel, em uma entrevista dada por ele a Tim Janof, publicada no site $<$ http://www.cello.org/Newsletter/Articles/mantel.htm>, acessado no dia 09 de novembro de 2007 (Op. cit., p. 4), intitulado Conversation with Gerhard Mantel (Conversa com Gerhard Mantel), falando sobre postura, lembra uma idéia importante, que não deve ser perdida de vista nestas reflexões: afirma que hesita fazer regras gerais para a postura, porque violoncelistas com diferentes posturas podem tocar igualmente bem. E esta pesquisadora acrescenta ainda: existem grandes músicos, de excepcional sucesso, tocando com as posturas mais diversas.

Quanto a essas questões, nas aulas dadas a esta pesquisadora, Rostropovich não manifestou a sua opinião, somente a opinião já citada anteriormente: "Se está a afinado 
e confortável está bom". Todas essas idéias, no entanto, buscam a mesma meta do conforto, ainda que não convergentes.

\section{Sobre o posicionamento dos cotovelos}

Sobre esse tópico parece haver uma concordância entre os autores: Rostropovich, Tortelier e Sazer condenam cotovelos excessivamente altos, assim como condenam também o outro extremo, os cotovelos excessivamente abaixados, pois os primeiros aumentam a tensão e o esforço, e os segundos diminuem a liberdade de movimentos dos braços.

\section{Divergências de escolas de mão direita}

Tortelier critica, indiretamente, a escola russa de mão direita, quando contesta o que ele conceitua como o modo "empírico" de "agarrar o arco com quase todo o punho", descrevendo o modo que é típico da escola russa, guardados os exageros da linguagem por ele empregada, e que é, mais precisamente, um posicionamento de pulso mais baixo, praticamente alinhado com o dorso da mão, do que o alinhamento que é usado na escola chamada de francesa ou de franco-belga (empregada por Tortelier), que o posiciona bem mais alto do que o dorso da mão.

Neste ponto, Tortelier vai de encontro às idéias expostas por Mstislav Rostropovich, que é mundialmente usado para exemplificar a escola russa de mão direita e também o tipo de som que este alinhamento de pulso e posicionamento de dedos acaba proporcionando. Nesse caso, a escola russa, devido à maior facilidade de se aplicar peso do arco e do braço na corda, proporciona um som muito mais pesado, mais alla corda (o que acaba facilitando os detachés e legatos muito mais sonoros e penetrantes) e, com a maior imobilidade causada por esse posicionamento de pulso, é dificultada a execução de articulações mais curtas e variadas.

Ou seja, como acontece em praticamente todas as escolhas, se há ganho por um lado, perde-se por outro, já que as articulações e as sutilezas nas diferentes arcadas são facilitadas pela escola franco-belga, mas o som perde em volume e ganha um timbre menos penetrante, se é que se pode descrever a sensação proporcionada por um som de maneira adequada. 
Já em relação à maneira de segurar o arco, o polegar, na escola russa (defendida e explicada por Rostropovich) é sempre posicionado reto, mantendo a preocupação de jamais tensioná-lo, o que costuma acontecer com maior freqüência nessa posição. Logo, deve estar reto e firme, mas relaxado. Para Tortelier, contudo, o polegar deve estar sempre curvado, o que ajuda imediatamente a mantê-lo relaxado, mas proporciona menor firmeza. Como acontece com a maneira de se empregar o pulso, cada maneira acarreta perdas e danos.

É hipótese da escola chamada franco-belga alegar que o polegar arredondado pode proporcionar maior mobilidade e flexibilidade ao arco e aos golpes de arco. É hipótese defendida pela escola russa que o polegar posicionado reto, sem se flexionar, proporciona maior firmeza, uma "pegada" sonora mais firme, de som de maior continuidade, principalmente em legatos e detachés.

Já em relação às funções dos dedos da mão direita, descritos pelos autores, Tortelier contradiz Rostropovich, ao afirmar que o primeiro e o quarto dedos, juntamente com o polegar, têm a função de segurar o arco, sendo que o segundo e o terceiro ajudariam e participariam, porém não com a mesma importância e funcionalidade. Já Rostropovich, em relação ao mesmo assunto, como já foi tratado, acredita que o segundo e o terceiro dedos, em contrapeso ao polegar, é que realmente têm a função de segurar o arco, enquanto que, para ele, a função do primeiro e do quarto é apenas a de gerar equilíbrio, não de gerar peso e nem sustentação. 


\subsection{Idéias únicas tratadas por cada autor pesquisado}

Sazer:

Alguns aspectos sobre técnica e sobre percepção corporal são tratados apenas por Sazer neste seu livro. Um deles, muito simples e óbvio, porém muito pertinente, é a questão da mobilidade constante do corpo (quadril, tronco, braços, e até mesmo pernas e pés) ao se tocar o violoncelo, a fim de evitar dores no corpo, principalmente as de coluna lombar e na região do pescoço e ombros, que, segundo esse mesmo autor, são dores freqüentes nos violoncelistas. Essa mobilidade também facilita a livre respiração, que é, segundo quase todos os autores, fator fundamental para uma boa execução técnica, em muitos casos.

Outra questão que somente Sazer relata é a da angulação da perna e do quadril para se sentar, que deve ser um ângulo maior do que os $90^{\circ}$ sempre tidos como "corretos", e que, como já foi mencionado diversas vezes aqui neste trabalho, segundo ele, com base em dados médicos por ele citados, acaba fazendo a coluna e o quadril se voltarem para dentro, sobrecarregando a coluna lombar e tensionando o corpo.

Discutindo seu livro, apresentado nesta dissertação, em entrevista com Victor Sazer, realizada por Tim Janof, publicada no site da "Internet Cello Society" 35

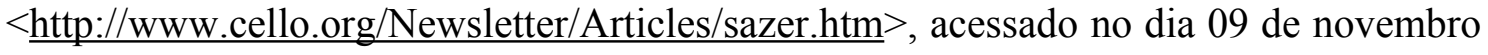
de 2007, Sazer afirma que buscou por respostas às perguntas: Problemas corporais relacionados com a performance podem ser evitados? Existem princípios objetivos ou critérios que distinguem uma prática saudável de uma prática prejudicial? Sazer, então, diz que encontrou respostas observando como usamos nossos corpos para executar tarefas ordinárias no dia-a-dia, e que aumentar a percepção de como executamos tais tarefas pode ser a chave de uma execução livre de dor.

Afirma também que a melhor maneira de aprender sobre o próprio corpo é observar como ele se sente ao executar os movimentos, pois ao observar, o corpo dá respostas que aprofundam nossa compreensão sobre como o corpo trabalha, por meio das sensações e das reações que ele tem.

\footnotetext{
35 “Sociedade do Violoncelo na Internet” como uma tradução literal.
} 
Uma observação pertinente feita por Sazer nesta entrevista é a de que quando os movimentos repetitivos geram uma grande quantidade de tensão eles se tornam perigosos, mas que nem todos os movimentos repetitivos criam tensão ou dor, alguns deles, inclusive criam alívio da tensão. Um desses movimentos é o vibrato, por exemplo, e o autor considera que o vibrato evita a tensão porque evita a imobilidade, que é também uma grande geradora de tensões. Ou seja, o uso repetitivo, para ele, não é a principal causa de tensões, mas sim o uso impróprio do corpo, que afete o equilíbrio deste.

Perguntado por Tim Janof se a dor é realmente tão prejudicial Sazer diz que "um pouco de dor" é o mesmo que "um pouco de gravidez", e que a dor é como um "alerta vermelho" nos pedindo para parar o que nos está prejudicando. Por isso, ele diz a Janof que quando sentirmos dor, o primeiro procedimento é parar e descobrir o que está nos causando dor, por meio de relaxamento, bem como observar como o corpo estava equilibrado, como se equilibrar ou equilibrar o movimento feito, sem tensão, e estar sempre atento aos sinais dados pelo corpo.

Sazer revela a Janof que o fato de estar sentado é o que mais prejudica uma boa compreensão dos movimentos e do equilíbrio do corpo e, por essa razão, harpistas e pianistas têm problemas semelhantes aos dos violoncelistas, ainda que o número de problemas de coluna, tendinites, problemas nos ombros e nos braços seja muito maior nos violoncelistas.

Contudo, a idéia mais inovadora exposta pelo autor, que também é discutida nessa entrevista, tanto quanto no seu livro, é a de que o corpo não foi feito para se sentar em um ângulo de $90^{\circ}$ entre o fêmur e a coluna, nem $90^{\circ}$ da parte inferior da perna com o fêmur, idéia que é amplamente divulgada como correta e amplamente difundida até mesmo em técnicas de correção postural. Baseado em artigo do Dr. Richard Norris, por ele citado, ele afirma que sentando em uma cadeira que é mais alta, adequada a cada pessoa, na qual os joelhos fiquem algumas polegadas abaixo da linha do quadril e os pés posicionados à frente da linha do joelho, a pessoa tem o mesmo suporte para as costas do que quando está em pé, evitando, dessa forma, uma série de tensões desnecessárias, e permitindo maior mobilidade ao corpo.

Ele afirma ainda que, quando dá palestras, leva várias almofadas (mais altas atrás do que na frente), de várias alturas, para que as pessoas provem, e que a primeira 
reação das pessoas ao sentarem desta maneira é um grande sorriso, pois aliviam tensões que muitas vezes eles nem sabiam que possuíam.

Perguntado ainda sobre a forma de uso de seu arco, Sazer responde que pensa no movimento do arco para baixo como o arco contornando a corda em sentido antihorário, e em sentido horário nos arcos para cima.

\section{Pleeth:}

Algumas questões são defendidas no livro de Pleeth e não são sequer mencionadas pelos outros autores. A primeira é o excesso de treino técnico pelos estudantes e violoncelistas, que acarreta vários problemas, dentre os quais pressão psicológica pela perfeição (o que acaba gerando erros), uma sensação de tornar o artista um novo tipo de atleta, que tem que tocar cada vez mais rápido e com maior intensidade de dinâmica em seu som, uma exclusão da preocupação de se desenvolver uma individualidade artística no músico, uma busca por padrões pré-determinados de interpretação (já tidos como consagrados) em detrimento de novas idéias, entre outros prejuízos.

Outro ponto sutil de interesse para professores, especialmente, que se assemelha muito ao item anterior, é o de tentar desenvolver no aluno sua busca pelo som, pela qualidade de som, pelo tipo de som que ele procura, desde a primeira aula, até mesmo com a corda solta.

Pleeth considera que normalmente essa busca é desenvolvida e estimulada tardiamente (após o aluno já ter aprendido as técnicas básicas para se tocar o instrumento), desviando o instrumentista de seu foco principal, que é o som, em função de preocupações de técnica, postura, rapidez, facilidade ou outros aspectos. Além de desviar a atenção do instrumentista do som por ele produzido, Pleeth acredita que a postura comumente empregada, alheia à qualidade do som e à musicalidade, treina o músico para preocupar-se sempre e exclusivamente com a técnica, o que ele considera absolutamente insatisfatório. 


\section{Tortelier:}

Seguramente, neste livro, a idéia apresentada que não é comentada em nenhum dos outros autores é o conceito do posicionamento do polegar da mão esquerda como sendo o responsável principal pela boa afinação.

Não se deve perder de vista que Tortelier, ao defender essa idéia, está falando apenas da técnica de mão esquerda que acredita que a forma de mão "correta" é a forma "quadrada", com equilíbrio de peso e função entre o primeiro e o quarto dedos, e o polegar sempre posicionado imediatamente atrás do segundo dedo, flexionado, e leve, como já foi dito.

Porém, somente Tortelier dá tamanha importância ao polegar da mão esquerda no quesito "afinação", e faz inclusive alusão à técnica pianística da transferência do polegar, que o autor acredita que, no violoncelo, poderia até mesmo ser feita de modo semelhante, inclusive em extensões e mudanças de corda.

Para ele, como ele explica, o polegar está sempre posicionado atrás do segundo dedo, também nas mudanças de cordas e de posições, podendo ajudar muito, por exemplo, no processo de mudanças de posição fechada para posição estendida, transferindo-se para o local em que ele terá que se posicionar após a mudança, antecipando-a, criando um ponto de apoio para a próxima posição após a mudança, auxiliando na afinação da posição para a qual está sendo transferida a forma da mão.

\section{Mantel:}

Uma idéia que é unicamente tratada por Mantel é a de que o músico não precisa, ao estudar uma passagem técnica, estudar a resistência e treiná-la como se fosse algo contra o qual os músculos têm de gerar resistência e força, mas sim, que ao treinar uma passagem técnica, esse instrumentista esteja treinando coordenação motora para ela.

Por exemplo, estaria treinando a união da mão esquerda com a direita, a seqüência de dedilhados, a questão das arcadas (quantas notas por arco, ou quais arcadas devem ser realizadas "para cima" e quantas "para baixo", para citar alguns exemplos), local onde deve posicionar seu arco, aderência do arco com a corda em 
determinada nota, entre inúmeros outros aspetos que devem ser estudados para que se adquira a correta coordenação na hora da execução, e não um treinamento de resistência e força.

E em relação a essa geração de coordenação motora, muitos professores aconselham que se estude a determinada passagem mais lentamente, muitas vezes, num andamento em que seja possível tocar todo o trecho corretamente (com a maior quantidade de detalhes possível que se exigirá depois, ao se executar a mesma passagem no andamento correto). Esta recomendação serve, principalmente, para que se sinta com mais clareza os detalhes da execução, como por exemplo, o dedilhado, a arcada, até mesmo a afinação correta, ou qualquer outro detalhe.

Além disso, a repetição lenta e correta faz a assimilação do trecho ter mais chance de se tornar eficiente (não se deve esquecer de Sazer: se estuda certo, aprende certo; se estuda errado, aprende errado também). A execução repetida muitas vezes, num andamento rápido, tende a levar o músico a executar a determinada passagem de diversas maneiras, não assimilando verdadeiramente nenhuma delas. E a geração de uma sensação de coordenação motora eficiente resulta principalmente da repetição (correta), do mesmo modo que a sensação de familiaridade a uma composição musical também resulta, muitas vezes, das repetições nela inseridas.

A autora Madeline Bruser, em seu livro já citado The art of practicing (Op. cit., 1997), afirma que sempre estranhou o fato de estar sentada ao piano em sua própria sala, completamente sozinha e livre para fazer o que quer que quisesse, e, ainda assim, cair em algum tipo habitual e insatisfatório de forma de trabalhar. Acredita que não sabemos o que fazer com nossa liberdade. Para ela, repetimos passagens de uma forma não prazerosa e desesperada de tentar adquirir segurança técnica. Alerta, então, que embora aprender uma peça necessite a repetição de passagens em um tempo mais lento do que o tempo de concerto, deve-se deixar permear a vivacidade, a abertura, a incerteza, a liberdade de uma performance.

Bruser acredita que desejar é diferente de ter ambição e, para ela, o desejo nos move adiante, mas a ambição gera tensão, desconforto e erros. Ela ainda alerta que uma das tensões mais freqüentes criadas em nossa prática vem do fato de se tentar tocar uma peça rapidamente, antes de se estar pronto para isso (Op. cit., pp. 10 -15). Ou seja, se 
queremos gerar melhor coordenação motora do que resistência física, uma prática mais prazerosa, sem muita ambição e sem muita pressa, pode ser bastante benéfica.

\section{Rostropovich:}

As questões mais marcantes propostas por Rostropovich que não são mencionadas pelos outros autores dizem respeito mais às maneiras de conceber e pensar sobre o estudo e a execução musical, além de elevar a mão direita a um status muito maior, pois acredita que a música é na maior parte realizada por ela, sendo a mão esquerda, para ele (assim como foi compreendido por esta pesquisadora), muito mais uma parte treinada mecanicamente.

Os conceitos de formas de se estudar mais pertinentes por ele tratados são:

- estudar aquilo de que se deseja fugir, ou seja, as dificuldades e deficiências;

- o artista é reconhecido pela sua mão direita, não pela esquerda;

- o músico precisa ter total controle prévio dos detalhes, por exemplo, quanta pressão, quanta crina, quanta velocidade de arco, qual a região do arco, quanto peso, quanta aderência vai usar para cada nota, em uma execução musical.

Outra idéia tratada apenas por Rostropovich é a da necessidade de se estudar uma hora de escalas e arpejos todos os dias. Essa idéia é afirmada por Hans Jorgen Jensen, na Introdução de seu livro (e adaptação para o violoncelo) The Ivan Galamian Scale System for The Violoncello (1994, p. 3). Jensen, tratando aqui especificamente do Sistema de Ivan Galamian de Escalas, mas também da importância do estudo de escalas, afirma que esse estudo auxilia no desenvolvimento da agilidade e controle da mão esquerda, além de ser uma ferramenta de valor inestimável para construir as habilidades básicas do braço do arco e para desenvolver a coordenação entre as duas mãos. Jensen também acredita que o estudo de escalas e arpejos desenvolve fortes imagens mentais e uma sólida sensação física e tátil do espaço do espelho.

Nesses aspectos, Rostropovich era bastante prático, buscando a resolução de problemas por meio de estudo, consciência e reflexão detalhista e aprofundada da 
música e do violoncelo. Em sua forma de pensar, Rostropovich se mostrava como alguém objetivo, que resolvia problemas, que sempre buscou com afinco a perfeição de sua execução, e afirmava que para se buscar essa mesma perfeição deve-se sempre observar o que não é fácil de executar e estudá-lo tanto, de modo que fique fácil, e então passar logo para outra dificuldade, a fim de resolver o maior número de problemas no menor período de tempo possível.

Margaret Campbell, em seu livro The great cellists (1988, p. 283), conta que o processo de aprendizagem de Rostropovich era muito interessante, pois ela afirma que ele nunca teve experiência de dificuldades técnicas e que seus professores sempre ficavam bravos com suas posições corporais, mas que, apesar disso, ele sempre procurou o conforto em sua maneira de tocar. Ela diz que, por essa razão, ele sempre foi flexível quanto às posições com seus alunos e que somente fazia regras que fossem estritamente necessárias, como ficar com o arco paralelo ao cavalete, por exemplo, e que quando perguntado sobre a maneira de realizar isso, respondia que não se preocupasse com isso, pois cada um tem um tamanho de braço. Segundo ela, ele dizia à pessoa que só se preocupasse em deixar o arco paralelo ao cavalete e perpendicular às cordas, além de estar confortável.

$\mathrm{Na}$ entrevista de Sazer, realizada por Tim Janof, já citada (Op. cit., 2007), contudo, essa idéia é contestada. Sazer responde sobre sua idéia apresentada, de o corpo gostar de movimentos circulares. A isso Janof contesta que se os movimentos forem circulares, o arco não ficará perpendicular à corda. Então Sazer responde: "Por quê o arco tem de estar perpendicular à corda?" Sobre isso diz que é impossível estar reto o tempo todo, e cita Leonard Rose, que disse certa vez que "não existem arcos retos". Além disso, o autor afirma que o arco responde mais rápido quando a ponta do arco está levemente inclinada para cima, nos arcos para baixo, e levemente inclinada para baixo, nos arcos para cima.

Em relação a ter poucas dificuldades técnicas, como afirmou logo acima Margareth Campbel, em entrevista realizada por Janof com Rostropovich (Op. cit., 2007), ao ser perguntado sobre seus estudos, quando jovem, o violoncelista respondeu que geralmente praticava duas horas por dia, no máximo. E que seu recorde foi um período de prática de quatro horas, quando Shostakovich the deu seu Concerto n. ${ }^{\circ} 1$, pois ficou muito empolgado, mas conta que, nos dias seguintes ao qual pegou a 
partitura, tocou cerca de dez horas por dia, e quatro dias depois já a estava tocando de cor. Conta ainda que teve muita sorte quando jovem, pois não necessitava praticar muito. Afirma até mesmo que era como se seus dedos tivessem memória própria, pois eles nunca se esqueciam do que eles deviam fazer.

Talento indiscutível à parte, esta pesquisadora acredita que grande parte do estudo de Rostropovich era estudar música, e não apenas a prática de seu instrumento, além de um estudo consciente e voltado principalmente para o foco da superação de problemas e dificuldades, e não simplesmente de prática repetitiva, conforme ele explicava. Essa prática objetiva, que atacava os problemas diretamente, certamente colaborou muito para suas performances impecáveis e memoráveis.

É atribuída a Rostropovich, correntemente, nas aulas de violoncelo, como tantas frases de efeito e histórias que são contadas oralmente, sem que se tenha a certeza de sua proveniência, a seguinte frase: "Meus alunos estudam oito horas por dia e terminam com o corpo doendo; eu estudo quatro, e termino com a cabeça doendo". Sendo ou não frase de Rostropovich, aí está embutido o mesmo conceito já explicado anteriormente: estudo consciente vale mais do que estudo "automático", pensar muito pode valer mais do que repetir, repetir e repetir. 


\section{5. Semelhanças em todos os autores}

Um conceito tratado de maneira semelhante por todos os violoncelistas pesquisados no Primeiro Capítulo é o de que o movimento ideal só pode ser sentido por toda a unidade do corpo, o que requer tensões conscientes e inconscientes de determinados músculos, a fím de se manter o equilíbrio de toda a unidade corporal, bem como o balanço do relaxamento e dessas tensões necessárias à firmeza.

Pode-se comparar esse equilíbrio de forças, tensão e relaxamento, por exemplo, com o ato de ficar de pé ereto: existem forças atuando para gerar a sustentação e o equilíbrio, mas esse não é um movimento em que seja necessário o uso de tensão (somente dos músculos envolvidos na sustentação, mas não de tensão ligada à força).

Assim, os autores concordam que para tocar também é necessário esse tipo de envolvimento de músculos, contrariamente a algumas idéias que os estudantes por vezes escutam de professores, em que lhes é falado que para se tocar deve-se sempre estar totalmente relaxado. Obviamente, esse conceito é muito mais "simbólico", alude principalmente ao relaxamento que é necessário para se tocar, não tratando das tensões necessárias envolvidas em qualquer movimento.

Contudo, todos os autores defendem que é necessário estar consciente da unidade entre corpo-mente-alma, que é absolutamente indispensável para uma prática técnica e artística eficiente, além de satisfatória ao próprio indivíduo. 
2. 6. Quadro comparativo de aspectos discutidos pelos violoncelistas

\begin{tabular}{|c|c|c|c|c|c|}
\hline & Sazer & Tortelier & Pleeth & Mantel & Rostropovich \\
\hline $\begin{array}{l}\text { Relaxamento } \\
\text { do Corpo }\end{array}$ & Fundamental & Importante & Fundamental & Importante & Fundamental \\
\hline Respiração & Fundamental & Fundamental & Fundamental & Fundamental & $\begin{array}{l}\text { Não } \\
\text { mencionada }\end{array}$ \\
\hline Postura & Fundamental & Fundamental & Importante & Importante & $\begin{array}{l}\text { Pouca } \\
\text { importância }\end{array}$ \\
\hline Conforto & Fundamental & Relativo & Fundamental & Fundamental & Fundamental \\
\hline Mão direita & $\begin{array}{ll}\text { Não defende } \\
\text { escola }\end{array}$ & $\begin{array}{l}\text { Escola } \\
\text { Francesa }\end{array}$ & $\begin{array}{ll}\text { Não defende } \\
\text { escola }\end{array}$ & $\begin{array}{ll}\text { Não defende } \\
\text { escola }\end{array}$ & Escola russa \\
\hline Mão esquerda & Mão quadrada & Mão quadrada & Mão inclinada & Mão inclinada & Mão quadrada \\
\hline $\begin{array}{l}\text { Polegar da } \\
\text { direita }\end{array}$ & Arredondado & Arredondado & Arredondado & $\begin{array}{l}\text { Varia } \\
\text { dependendo da } \\
\text { região do arco }\end{array}$ & $\begin{array}{l}\text { Reto, porém } \\
\text { relaxado }\end{array}$ \\
\hline $\begin{array}{l}\text { Polegar da } \\
\text { esquerda }\end{array}$ & $\begin{array}{l}\text { Arredondado, } \\
\text { mas flexível }\end{array}$ & Arredondado & Arredondado & $\begin{array}{l}\text { Irrelevante se é } \\
\text { arredondado ou } \\
\text { não }\end{array}$ & $\begin{array}{l}\text { Não } \\
\text { mencionado }\end{array}$ \\
\hline Estudo criativo & $\begin{array}{l}\text { Não } \\
\text { mencionado }\end{array}$ & Importante & Fundamental & Importante & Fundamental \\
\hline $\begin{array}{l}\text { Estudo técnico } \\
\text { árduo }\end{array}$ & $\begin{array}{l}\text { Importante, } \\
\text { com cautelas }\end{array}$ & Fundamental & $\begin{array}{l}\text { Importante, } \\
\text { com cautelas }\end{array}$ & $\begin{array}{l}\text { Importante, } \\
\text { com cautelas }\end{array}$ & $\begin{array}{l}\text { Fundamental, } \\
\text { com cautelas }\end{array}$ \\
\hline $\begin{array}{l}\text { Técnica antes } \\
\text { da } \\
\text { musicalidade? }\end{array}$ & $\begin{array}{l}\text { Não } \\
\text { mencionado }\end{array}$ & Sim & Não & Não & Não \\
\hline $\begin{array}{l}\text { O estudo da } \\
\text { técnica pode ser } \\
\text { separado da } \\
\text { musicalidade? }\end{array}$ & Sim & Sim & Não & $\begin{array}{l}\text { Para fins de } \\
\text { estudo }\end{array}$ & Sim \\
\hline $\begin{array}{l}\text { Sofrimento ao } \\
\text { estudar }\end{array}$ & Desnecessário & $\begin{array}{l}\text { Necessário, } \\
\text { muitas vezes }\end{array}$ & Desnecessário & Desnecessário & Desnecessário \\
\hline
\end{tabular}


Terceiro Capítulo. O ensino e a aprendizagem do violoncelo em nosso país, especificamente em São Paulo: visões de educadores do violoncelo. 
Terceiro Capítulo. O ensino e a aprendizagem do violoncelo em nosso país, especificamente em São Paulo: visões de educadores do violoncelo.

\author{
"The cellist's mission is to keep alive treasures of \\ beautiful music that would otherwise sleep forever". \\ DMITRY MARKEVICH
}

Serão entrevistados, a seguir, três violoncelistas, que também são renomados professores de violoncelo dentro do cenário musical paulista, especificamente os professores das maiores universidades públicas paulistas, USP, UNESP e UNICAMP. As entrevistas tratarão dos temas abordados nas resenhas dos livros pesquisados, e no seguinte cruzamento de dados feito no Segundo Capítulo, bem como das reflexões expostas por esta pesquisadora.

Os violoncelistas entrevistados serão: Prof. Robert Suetholz (USP), Prof. Dimos Goudaroulis (UNICAMP) e Prof. Fábio Presgrave (UNESP).

Estas entrevistas pretendem ser um novo meio de reflexão sobre os assuntos já abordados nos capítulos anteriores, com base nesses três diferentes pontos de vista de educadores de expressiva atuação no Brasil, de modo a exemplificar o pensamento corrente sobre a técnica e a execução artística do violoncelo no meio acadêmico musical público, específico do Estado de São Paulo.

Tendo em vista que esses três professores têm grande importância para a formação de violoncelistas profissionais, tanto instrumentistas como professores, além de uma formação muito ampla (cada uma à sua maneira, com sua formação pessoal e artística) como estudiosos da técnica do violoncelo, e também como intérpretes, esta pesquisadora acredita que tais entrevistas contribuirão também como um "microcosmo" para um panorama específico do ensino do violoncelo no Brasil, já que São Paulo é uma das cidades de grande efervescência musical no país, se não a de maior movimentação cultural.

O modo das entrevistas será o de entrevista objetiva, com questionário rígido, com o objetivo de produzir um material que transcenda o respondente individual, e que 
possa ser observado com fins comparativos. Por isso, para as três entrevistas serão utilizadas exatamente as mesmas perguntas, a fim de facilitar a comparação.

Deve se notar, a título de curiosidade, além de tudo, que uma entrevista também tem um caráter social, e por isso há sempre o efeito das personalidades envolvidas, havendo também uma relação de confiança, cooperação e respeito mútuo. Também é necessário acrescentar que foi avisado aos entrevistados, anteriormente, o tipo da entrevista que seria feita, sobre qual assunto específico, qual a finalidade da mesma, bem como sobre a pesquisa de Mestrado elaborada por esta pesquisadora, na qual a entrevista seria apresentada integralmente.

Foi oferecida aos entrevistados a opção de que a entrevista fosse feita pessoalmente (e gravada para posteriormente ser transcrita fielmente), ou por e-mail. Houve a opção pela entrevista escrita, realizada por e-mail, pelo Prof. Robert Suetholz, e a entrevista feita pessoalmente, gravada, e posteriormente transcrita na íntegra, pelos Profs. Presgrave e Goudaroulis.

Observe que não existem respostas corretas, nem erradas, elas somente expressam opiniões pessoais em relação a determinados assuntos, neste exato momento da vida de seus entrevistados. As entrevistas foram realizadas no período de setembro e novembro de 2007, e foram, após sua elaboração (transcrição e revisão), enviadas por email para os respectivos entrevistados, e sua versão final, aqui apresentada, obteve a autorização e permissão para que essas entrevistas fossem apresentadas, como estão, no presente trabalho.

Observe que não somente as respostas apresentam características de personalidade individuais de cada entrevistado, como, por exemplo, a prolixidade ou objetividade das respostas, o grau de exposição pessoal, a intenção de ilustrar com exemplos, e esta pesquisadora acredita que, embora todas as entrevistas tenham obtido êxito em relação às respostas apresentadas, também revelam características subjetivas pessoais dos entrevistados, tanto como professores, quanto como intérpretes. 


\section{1. Entrevistas}

Segue a relação das perguntas realizadas com os três professores, aqui dividida em partes, que representam blocos de assuntos diversos:

Parte A - Sobre a Formação Violoncelística e a Técnica

1. Qual foi a sua formação no violoncelo?

2. Você considera que teve acesso a uma base técnica e teórica suficiente? Se não, o que faltou e como você superou essas carências?

3. Você considera pertencer a uma escola violoncelística? Qual e por quê?

4. Você acredita que uma determinada escola seja melhor? Para você existe o certo e o errado?

5. Como você segura seu arco? Por quê?

6. Qual é a sua maneira de uso da mão esquerda? Por quê?

7. Qual a importância do polegar da mão esquerda para você? Como você o usa?

8. Você acredita que devemos ter uma "forma de mão"?

9. Para você os dedos da mão esquerda devem estar sempre abertos em uma posição enquanto tocamos, ou não, esta posição deve ser adaptável e relaxada?

Parte B - Sobre Maneiras de Estudar

10. Como é seu estudo diário? Existe uma rotina? Existe uma programação prévia?

11. Para você o que é mais importante a se buscar e pensar, no estudo diário?

12. Você faz tudo o que seus mestres pregavam? Algo foi adaptado? O quê? Por qual razão?

13. Você se preocupa em testar novas idéias divergentes das suas?

Parte C - Parte Motora e Dificuldades Físicas

14. Você se preocupa com tensões no corpo? Sente alguma? Elas atrapalham ou 
atrapalharam de alguma maneira a sua execução? Faz ou fez efetivamente algo para melhorá-las?

15. O que você acha sobre a idade em que alguém deve iniciar seus estudos de violoncelo? O que você acha da realidade brasileira em relação a esse assunto?

Parte D - Realidade Brasileira

16. Quais as maiores carências dos alunos brasileiros, em sua opinião?

17. O que poderia ser feito para melhorar a realidade brasileira?

Parte E - Interpretação

18. Você acha que a musicalidade só se evidencia após o aprendizado sólido de bases técnicas e teóricas?

19. Como você constrói a interpretação de uma obra musical?

20. Qual o diferencial expressivo do violoncelo para você? 


\section{1. 1. Entrevista com o Professor Robert Suetholz (USP).}

(Realizada em 20 de outubro de 2007)

\section{Qual foi a sua formação no violoncelo?}

Eu comecei a estudar violoncelo na escola pública, com um colega do meu pai (que também foi professor de música na rede de escola pública em Racine, WI), durante o verão em que completei dez anos de idade: meu aniversário é 30 de agosto. Pouco tempo depois, eu passei a ter aulas particulares com a esposa desse professor que me iniciou, que era uma das melhores cellistas da cidade onde eu morava, estudando com ela durante uns dois ou três anos, até que ela disse aos meus pais que eu deveria ter outro professor melhor. Daí eu tive aulas com dois ou três professores diferentes em Milwaukee , uma cidade vizinha, até chegar na Universidade de Wisconsin-Milwaukee, em 1978, onde fui aceito na classe de George Sopkin.

Devo dizer que cada um desses professores achou por bem mudar a minha técnica. Talvez seja por isso que não tenho problemas com idéias novas, e acho que acabei absorvendo tudo que era útil das idéias diferentes desses professores todos. Na UWM não foi diferente. Mudei de novo algumas coisas e foi a primeira vez em que algum professor se preocupou com a tensão que eu tinha nos meus ombros. Lembro-me, até hoje, o George atrás de mim empurrando os meus ombros para baixo, enquanto eu tocava o Concerto de Schumann.

No segundo ano da universidade, o George se aposentou do Fine Artes Quartet e veio o Wolfgang Laufer para substituí-lo. O Wolfi novamente mexeu na minha técnica, na mão direita e tive dois anos de aulas com ele até ir para o meu primeiro emprego em Beer-Sheva, Israel: a Israel Sinfonietta. Lá eu fui contratado para ser o concertino, mas acabei assumindo o lugar de spalla dos violoncelos, éramos quatro.

Em Israel, eu tive aulas com o Uzi Wiesel, violoncelista do Quarteto de TelAviv e antigo professor do Wolfi. Ele novamente mexeu na minha mão direita, e acho que o jeito que seguro o arco hoje tem mais a ver com o jeito que ele me ensinou; só que eu uso toda a crina agora, e ele me ensinou a usar o arco "deitado". Ele puxou a minha mão para trás, deixando o segundo dedo - em termos cellistícos... polegar, um, dois, etc. - em contato com o anel do talão e os dedos mais juntos, também. Quando eu 
resolvi utilizar toda a crina, eu acabei mexendo com a mão que ele me ensinou, mas acho que continuo com o espírito da mão dele.

Desde então eu não tenho mudado a minha técnica para nenhum professor... a não ser para mim mesmo. Em 1984-85, voltei a estudar na UWM com o Wolfi e, em 1985, vim para o Brasil. Aqui eu nunca tive aulas com ninguém, e comecei a dar aulas na Escola Municipal ${ }^{36}$ em 1987, e passei para USP em 1989, onde estou até hoje. Em 1997, eu tirei um ano de licença para completar o meu Mestrado na Northwestern University em Chicago (Evanston), Illinois, nos EUA. Lá eu estudei com Hans Jorgen Jensen. Ele me ajudou muito com problemas de tensão que eu estava tendo, me passando muitos exercícios de vibrato, etc, para tentar ajudar a resolver esses problemas.

\section{Você considera que teve acesso a uma base técnica e teórica suficiente? Se não, o que faltou e como você superou essas carências?}

Sim.

\section{Você considera pertencer a uma escola violoncelística? Qual e por quê?}

Se eu pertencer a alguma escola, seria a do Bernhard Greenhouse, que foi professor do Uzi Wiesel e do Wolfgang Laufer, que foi aluno de Casals, de Feuermann e de Felix Salmond, que, por sua vez, foi professor de Leonard Rose, com quem estudou Jenson. Acho que poderia se comparar a minha mão direita à escola franco-belga do violino. Mas acho que não pertenço, não.

O meu jeito de tocar tem coisas de várias escolas, inclusive da escola russa, pois acho que tem hora para tudo. Por exemplo, na hora de tocar forte eu posso avançar o dedo indicador, ou mesmo a mão inteira, para ter mais peso na corda, com menos trabalho. Logo que não preciso desse peso todo (precisa ser muito forte para eu precisar fazer isso), eu volto a minha mão para a sua posição inicial, para ter mais flexibilidade novamente.

\footnotetext{
${ }^{36}$ Nota da pesquisadora: Escola Municipal de Música de São Paulo.
} 


\section{Você acredita que uma determinada escola seja melhor? Para você, existe o certo e o errado?}

Acho que tem escolas boas e ruins. Mas nenhuma escola é de todo ruim. A escola russa, por exemplo, prega um som enorme e por isso o jeito de segurar o arco é um pouco diferente, na escola de violino também. Outras escolas acham melhor resolver outros problemas. Cada técnica diferente dá importância mais para uma coisa ou outra. Tudo o que fazemos é uma escolha. Se escolher mais som, sempre vai prejudicar a flexibilidade da mão direita, por exemplo. Esta flexibilidade poderia trazer outros benefícios, mas acaba prejudicando um som maior.

Certo é aquilo que não fere o corpo e errado é ao contrário. O resto são maneiras diferentes de conseguir a mesma coisa, ou escolhas de acordo com a importância dada a um ou outro aspecto da técnica do violoncelo. Ou melhor, de fazer música.

\section{Como você segura seu arco? Por quê?}

Seguro com o segundo dedo no anel do talão e o dedo mínimo no final do talão, com a primeira falange em contato com a lateral do talão e com as pontas dos dedos alinhados. Gosto de sentir os dedos em contato com a lateral do talão, fora o primeiro. Deixo os dedos mais ou menos perto um do outro. Se eu quiser um pouco mais de som, eu ponho o dedo indicador mais para frente, na baqueta, ou mesmo a mão inteira, para ter mais peso na corda, com menos trabalho. Logo que não precise desse peso todo (como eu já mencionei antes, precisa ser muito forte para eu precisar fazer isso), eu volto a minha mão para ter mais flexibilidade novamente.

Outro dia, um aluno apareceu com a mão toda mais para frente, técnica que tive, enquanto estudando com o Laufer, e me mostrou como o polegar pode se cansar menos se o segundo dedo estiver à frente do anel, e o terceiro estiver no anel. Desta forma, o segundo dedo vai ajudar o primeiro na hora de levantar o arco, e o polegar vai estar mais para dentro, entre o segundo e terceiro dedos, facilitando o trabalho na hora de transmitir mais peso para o arco. Parece que o polegar trabalha menos desse jeito, mas senti que a mão ficou um pouco menos flexível. Melhor do que com os dedos todos separados, forma que limita muito a nossa flexibilidade. Acho uma técnica viável, que pode dar bons resultados, ainda mantendo a maior parte das vantagens que se tem com a 
mão mais para trás, flexibilidade. Eu queria uma maior flexibilidade da mão direita, dos dedos, e queria tocar com toda a crina.

\section{Qual é a sua maneira de uso da mão esquerda? Por quê?}

Achei difícil essa pergunta. Bom, um exemplo, então. Gosto de manter os dedos em cima da corda, quando as passagens são rápidas. Se deixar o dedo - a palavra chave é deixar - na corda, sem pressionar e sem tensionar, ele vai estar pronto para ser usado logo em seguida, quando a escala retorna à sua descida. Tem escolas que pregam o levantamento de cada dedo, para ser recolocado logo depois. O Del Claro ${ }^{37}$ ensina assim... e ele toca "pra caramba". Acham que isso vai ajudar no relaxamento da mão e também na dicção. É verdade que a dicção pode melhorar, mas acho que podemos pensar em fazer dicção na hora de tirar os dedos da corda (com um leve pizzicato), para resolver isso. A mão não fica nem mais tensa e nem mais relaxada levantando os dedos das cordas, para serem recolocados logo em seguida.

É claro que isso tudo depende da hora certa. Os dedos têm de se movimentar também, para não acumular tensões. O polegar não deve ficar muito baixo, atrás do braço. Isso fecha a palma da mão e acaba tensionando também. Os dedos da mão ficam levemente inclinados, mas não demasiadamente, como os violinistas. A mão, mais ou menos quadrada. Contato com a ponta carnuda dos dedos, que são por sua vez curvos. Respondi?

\section{Qual a importância do polegar da mão esquerda para você? Como você o usa?}

Eu tento imaginar o polegar como um dedo guia. Não gosto de apertá-lo, mas tem hora que faço, por necessidade ou por esquecimento, simplesmente. Ele deve ser móvel, e talvez um pouco mais para cima do que muitas escolas ensinam. Atrás do primeiro dedo, ou um pouco abaixo. Tem horas que ponho acima do primeiro dedo, e na hora de vibrar eu posso abaixar um pouco, dependendo do dedo que está sendo utilizado.

\footnotetext{
${ }^{37}$ Refere-se ao violoncelista e professor brasileiro Antônio Lauro Del Claro.
} 


\section{Você acredita que devemos ter uma "forma de mão"?}

Acredito, mas isso não quer dizer que os dedos ficam no seu lugar exatamente acima das notas esperando serem chamados à ação. A mão fica relaxada e os dedos ficam acima da corda, quando não estão sendo utilizados. Não gosto de tirar um dedo da corda quando sei que logo vou precisar descer ele de novo, mas não insisto que este fique exatamente no seu lugar. Só que fique na corda, até a hora certa.

9. Para você, os dedos da mão esquerda devem estar sempre abertos em uma posição enquanto tocamos, ou não, esta posição deve ser adaptável e relaxada?

Acho que respondi isso na pergunta 8 .

\section{Como é seu estudo diário? Existe uma rotina? Existe uma programação prévia?}

Não tem rotina e existe programação prévia só no sentido de estar preparando as obras que vou tocar antes, para não ficar surpreendido.

\section{Para você, o que é mais importante a se buscar e pensar, no estudo diário?}

Aquecimento. De ficar de bem com o violoncelo e sentir que ele faz parte do meu mundo e não é um ser estranho. De tocar relativamente relaxado, sem gastar energia desnecessária.

12. Você faz tudo o que seus mestres pregavam? Algo foi adaptado? O quê? Por qual razão?

Acho que já respondi um pouco isso. Talvez a coisa maior que eu mudei foi a maneira de me sentar com o violoncelo. Eu aprendi a me sentar com o violoncelo centrado entre as pernas e agora eu toco com ele mais pro lado esquerdo e virado. Dessa forma, eu espero estar me sentindo bem nas duas cordas do meio e, quando for a hora de tocar na corda lá ou dó, eu viro o meu tronco um pouco, para ter acesso com o braço direito e espaço do lado esquerdo. Antes, eu sempre tive de me virar muito, pois estava preparado para tocar nas duas cordas mais graves. 


\section{Você se preocupa em testar novas idéias divergentes das suas?}

SIM. Acho que eu já peguei idéias de livros como o do Victor Sazer, New Directions. Acho que é por isso que pensei em deixar o cello mais para o lado esquerdo. Em contato com a perna esquerda, no meio do meu peito (dependendo), e no chão. Dessa forma a perna direita não precisa estar sempre segurando o cello. Gostei dessa idéia e tomei para mim. Fora a história do meu aluno, na resposta 5.

\section{Você se preocupa com tensões no corpo? Sente alguma? Elas atrapalham ou atrapalharam de alguma maneira a sua execução? Faz ou fez efetivamente algo para melhorá-las?}

Preocupo-me muito, e ainda sinto que não estou livre de tensões na hora de tocar. Uns anos atrás eu comecei o meu ano sem poder passar minhas três semanas de "saneamento básico", após as minhas férias. Sempre gosto de parar de tocar o cello -ultimamente não tenho tido essa possibilidade - durante um mês ou dois. Depois é necessário um período de "saneamento básico" para voltar a me sentir de bem com o violoncelo novamente. Isso inclui escalas, arpejos, estudos, exercícios e, é claro, música. Mas tudo isso sem pressão e com toda calma.

Começo com uma ou duas horas de estudo e vou aumentando. Como um atleta faria: nós somos atletas, não se esqueça. Não espero voltar a me sentir bem em uma semana e nem em duas. É saneamento básico mesmo, e acho que me deixa mais com vontade de tocar se eu parar de tocar, no final de cada ano. Enfim, dessa vez eu não consegui fazer esse saneamento e tive de fazer uma gravação comercial (acho que foi com a Vânia Bastos) e acabei não parando mais, para voltar na minha forma usual. Eu sei que, no meio do ano, os meus colegas do quarteto notaram que o meu ombro esquerdo estava mais alto do que de costume. No final do ano já estava tendo problemas para vibrar nas posições graves $\left(1^{\mathrm{a}}-3^{\mathrm{a}}\right.$ posição), mas estava bem a partir da quarta posição.

Se eu tivesse parado para resolver esse problema, eu não teria sofrido o que sofri depois. Acabei tendo problemas de coluna e me tratei com quiropraxia, recomendo muito, e tive de repensar muitas coisas da minha técnica violoncelística e até do meu jeito de viver. Fiz curso de Técnica Alexander, Feldenkrais, tive sessões de acupuntura 
etc. Enfim, hoje eu sinto que sei o que deveria fazer, mas nem sempre eu faço na hora do "vamo ver".

Sinto tensões, sim. Eu trato com muito alongamento e, hoje em dia, eu freqüento a academia para fazer musculação, onde eu me alongo antes e depois. Acho que isso tem ajudado o meu corpo a se recuperar de eventuais lesões causadas nas horas mais tensas, enquanto estou tocando o violoncelo, e até a ficar mais relaxado.

15. O que você acha sobre a idade em que alguém deve iniciar seus estudos de violoncelo? O que você acha da realidade brasileira em relação a esse assunto?

Acho que deve começar com uns dez anos de idade. A realidade brasileira nem sempre permite isso. Acho uma pena, mas mesmo assim tem muitos cellistas bons por aí que começaram com dezesseis, dezoito anos. Iniciar os seus estudos de violoncelo mais tarde não impede que a pessoa possa ser um violoncelista e ganhar a vida com isso. Mas acho que o corpo de uma criança, de dez a catorze anos, é muito mais apto para aprender coisas novas do que um corpo de dezesseis, dezoito anos. Não vamos esquecer a parte mental também. Criança tem mais facilidade em aprender novidades.

\section{Quais as maiores carências dos alunos brasileiros, em sua opinião?}

Ter acesso à música desde cedo. Se tivesse o ensino da música nas escolas públicas, seria um grande avanço, na minha opinião.

\section{O que poderia ser feito para melhorar a realidade brasileira?}

Além da resposta acima, ter mais projetos como os de Baccarelli, em Heliópolis, da "Orquestra Pão de Açúcar", da Renata Jaffé, ou mesmo os "CEUS", da Prefeitura de São Paulo. Oferecer a oportunidade das pessoas mais carentes estudarem um instrumento e/ou tocarem numa orquestra. 
18. Você acha que a musicalidade só se evidencia após o aprendizado sólido de bases técnicas e teóricas?

NÃO. Mas a musicalidade muitas vezes acaba só sendo empregada após o aprendizado dessas bases, infelizmente.

\section{Como você constrói a interpretação de uma obra musical?}

Não sei dizer. Difícil essa pergunta. Bom, eu procuro aprender as notas e decidir dedilhados e arcadas que vão poder ajudar as frases e, durante esse tempo, vou sentindo o que a música tem a dizer e como eu devo tocar para poder expressá-la da melhor forma possível.

\section{Qual o diferencial expressivo do violoncelo para você?}

Acho que o fator principal é a enorme quantidade de timbres que podemos realizar. Também acho que a tessitura do violoncelo ajuda, pois pode ser tocado grave, como um contrabaixo e agudo, como um violino. A expressividade da mão esquerda é importante também. Glissandos e vibrato. Escolhas importantes na hora de fazer música. Não sei se respondi bem a essa pergunta. 


\section{1. 2. Entrevista com o Prof. Dimos Goudaroulis (UNICAMP)}

(Realizada em 25 de outubro de 2007).

\section{a) Qual foi a sua formação no violoncelo?}

Eu comecei de uma maneira tradicional. Eu estava na Grécia, meu país, comecei com dez anos de idade; algumas pessoas na Europa acham que já é tarde, tem quem comece com seis, sete. Mas o violoncelo é um instrumento grande, talvez seja um pouco complicado começar muito jovem, acho. Não é como o violino, que tem a facilidade do tamanho. Comecei com dez anos no Conservatório da minha cidade, que era particular.

Tem o conservatório Nacional, lá na Grécia, em Atenas, que tem uma certa fama, mas a gente não tem uma grande tradição lá, também, como aqui no Brasil, em

música erudita. É a Europa, a Grécia, mas ao mesmo tempo é um país meio oriental, não tem uma grande tradição, nem uma escola violoncelística.

Comecei num conservatório legal, na cidade de Tessalonica, uma cidade grande, a segunda do país, tem algum nível. Tem a Orquestra Sinfônica Nacional, tem coisas que acontecem lá. Era um Conservatório novo, com um pessoal novo, professores interessantes, e lá fiz meus estudos básicos de violoncelo. Lá se separa os estudos em três fases. A primeira fase, que chamam de preparatório, o ensino médio, e os três anos superiores. Não que seja Superior, mas que é o mais alto daquele nível, no Conservatório. Eu fiz isso um pouquinho mais rápido, dos dez anos aos dezoito anos. Em sete, oito anos, peguei meu diploma, fiz um recital de formatura, digamos, o primeiro diploma de violoncelo.

Estudei, praticamente, com um professor por muitos anos, não era um violoncelista excepcional, mas era uma pessoa muito querida para mim, me ensinou muita coisa. Me deu todas as bases do violoncelo, mas era um violoncelista grego, tocava na orquestra, não tinha nenhuma "carreira", não era um professor famoso. Era um cara que tinha muita facilidade para se comunicar comigo, era legal com crianças, e também, depois, como adolescente, eu me reconheci com ele, foi uma relação muito boa. Acho isso essencial, com certeza ajudou muito.

Tive uma sorte, antes de viajar para Paris, que foi a seguinte: no último ano do Conservatório, com dezessete anos de idade, chegou lá um violoncelista húngaro, chamado Ivan Bianchi. E o meu professor grego, o Yorgos, um cara extraordinário, teve 
toda a humildade de reconhecer que o Ivan era um grande cellista, um cara que tocava muito bem, e meu professor falou: "Olha, eu vou te passar pra ele". No último ano, ele poderia ter um aluno dele formado, eu era, digamos, o bom aluno do Conservatório, ia fazer um diploma bem legal, para aquela época, na Grécia, fez meio barulho, porque eu toquei coisas difíceis, mas ele nem pegou essa glória, me deixou estudar esse último ano com esse húngaro, que me passou outras coisas, novidades para mim.

Eu não tinha nenhum contato com o exterior, ainda, era um adolescente, ia acabar a escola com dezoito anos, não tinha viajado muito, não tinha visto outras pessoas tocarem, outros estudantes tocarem super bem, lá em Paris ou na Alemanha, tudo aquilo que a gente sabe, e chegou esse húngaro, que me colocou várias dificuldades, fiquei assustado, no começo, nunca tinha estudado esse tipo de coisas. Ele chegou lá e falou: "Para ter o diploma, você tem que tocar, no mínimo, um movimento, para não falar a Sonata inteira do Kodály”. De repente.

Eu estudei muito com ele, naquele ano, me lembro que tivemos um problema de comunicação, ele não falava inglês, nem francês e eu não falava alemão, então eu tive meio que aprender, pra me comunicar com ele, a falar alemão, virou uma coisa de amigo, também. A gente se entendeu por afinidades violoncelísticas, não tem muita linguagem para falar, mas você consegue se comunicar.

Fiz meu diploma com ele, que me deu um "empurrãozinho" para frente, que não foi o suficiente também, foi só um ano, e, quando peguei meu diploma em junho não sabia o que fazer, aonde eu ia. Queria sair do país, ia fazer dezoito anos em setembro de 1988 e não sabia, não tinha grana também, não tinha muita ajuda: estava entre Alemanha e França. Eu tinha razões para ir aos dois países, e em agosto, no último minuto, antes de eu sair e fazer minha vida, chegou mais um professor búlgaro no Conservatório em que eu estava estudando, que se chama Russi Dragnev, que está ainda lá, na Grécia.

Ele também não é um violoncelista famoso, mas é muito sólido, e eu tive esse contato de um ano e alguns meses com essa escola, digamos, do Leste Europeu, que era uma escola muito sólida, muito forte, naquela época, aquela escola russa... os búlgaros, os romenos têm um jeito muito parecido de tocar.

O professor húngaro e o Russi, acredito, tinham um jeito muito parecido de ensinar, de tocar também, bem robusto, com muito som, extraordinária facilidade de 
tocar, eu sempre fiquei fascinado; eles tocam com a mão sem muita tensão, sem fazer muitas extensões, tudo muito mole e fechadinho, vão mudando de posição como se fosse nada, o polegar, ...é desconcertante, não é?

Eu tive essa sorte, eles simpatizaram muito comigo, e para mim isso é muito importante. Foi muito importante, como aluno, eu era um adolescente difícil e revoltado, então acho que foi muito importante os professores ficarem perto. Sempre tive uma amizade com eles, senão eu ia cortar um pouquinho, naquela época eu não facilitava muito.

Um mês antes de eu viajar, ele reconheceu algum talento em mim e me convidou, ele estava chegando lá, não sabia nada, não falava grego, não tinha grana, mas me convidou a passar um mês com ele, na casa dele, direto, para "me preparar para ir para Paris". Me deu, em um mês, tanta coisa concentrada que eu não tinha tido durante esses anos, muitos toques, muitos truques de técnica, de arco, de mão esquerda, de relaxamento, coisas assim. Eu o considero também como professor, mesmo que eu o tenha visto por um mês e meio, antes de eu sair, pra sempre, para fora da Grécia.

Essa foi minha formação básica. Depois, continuei meus estudos em Paris, os estudos Superiores de violoncelo. Ganhei uma bolsa do Estado francês e isso me fez tomar a decisão de ir para Paris, em vez da Alemanha. Naquela época, tinha encontrado um professor que era meio famoso, lá em Hannover, na Alemanha, que chamava Zigfried Zelheim, um professor alemão, que, infelizmente, morreu faz alguns anos, agora, de câncer, jovem, um professor muito bom... vários amigos gregos tinham ido pra lá pra estudar com ele, havia esse caminho aberto, eu tinha encontrado com ele...

E aí pintou essa bolsa do Estado francês, e eu falei "então vou pra França”. Fui fazer um curso de verão em Nice, sul da França, onde eu trabalhei com Phillipe Muller; Phillipe Muller é um dos professores de violoncelo do Conservatório Nacional Superior de Paris, era naquela época o principal dos cinco professores de violoncelo do Conservatório, um cara muito importante, e relativamente jovem. Encontrei com ele, fiz o curso de verão, e ele falou "Vem lá e eu te aceito". Fui a Paris e completei a minha formação superior.

A minha história é um pouquinho particular, sendo rebelde... chegando em Paris eu tinha muita vontade de tocar Jazz, ouvia muito, tinha conhecido essa música já na Grécia, e eu não conseguia muito me conformar dentro do mundo da música erudita. $\mathrm{E}$ 
o Conservatório, na França, é muito sólido, mas ao mesmo tempo muito fechado, a relação com o professor é muito fria, eles falam de um jeito muito distante, não é uma coisa muito fácil. Não funcionou comigo. Passei um ano com o Phillipe Muller e abandonei os estudos.

Comecei a tocar Jazz, abandonei a música erudita, e num momento entendi que tinha que acabar meus estudos, completar e pegar meu diploma. Voltei pra École Normale, que é uma Escola de Música Superior, em Paris, onde estava ensinando uma violoncelista francesa, da velha geração, que se chamava Reine Flachot, foi uma violoncelista famosa, que tem gravações, era daquela geração que conheceu o Casals, amiga do Rostropovich, tinha um jeito antigo de tocar, mas era uma mulher muito dinâmica, uma professora maravilhosa, que de verdade completou, de uma maneira profunda, não só no sentido formal de pegar o diploma de execução, os meus conhecimentos de violoncelo, na técnica, na maneira de estudar, o estilo francês, a escola francesa de arco, que a gente, imagino, vai comentar depois...

Ela talvez tenha sido a mais marcante na minha formação. Tenho que acrescentar aqui que a minha formação, de verdade, como músico violoncelista, foi completada, muito ampliada, pelo resto das coisas que eu fiz e não só pela "academia". Isso é uma coisa particular, minha, com certeza. Acredito hoje, e falo pra meus alunos, que aprendi muito mais, o que faço hoje como violoncelista veio mais do que eu fiz fora do Conservatório, do que dentro.

Isso é polêmico, claro, obviamente precisamos estudar no Conservatório, um instrumento erudito, que tem uma estrutura, séculos de tradição, não podemos cancelar essa tradição e fazer o que a gente quer, impossível, isso aí, como professor, eu nunca vou defender. Mas, eu, como músico, me formei mais pela minha experiência de vida, mesmo.

Em Paris toquei muito Jazz, virei um violoncelista de Jazz; toquei, durante os sete anos que eu estava lá, profissionalmente, com muita gente muito importante. Tive essa sorte de pegar na fonte, de trabalhar com pessoas muito mais importantes que eu, e muito mais velhas também, que tinham uma outra experiência, que me passaram muita coisa, de mestre para aprendiz, mesmo. Foi um aprendizado antigo, mais antigo do que os conservatórios, que começaram lá na Revolução Francesa, no final do século dezoito. Essa relação de mestre e aprendiz e de colega. De aprender tocando, na raça mesmo, e 
eu quis ampliar muito a minha experiência musical. Toquei com africanos, com indianos. Paris é uma cidade muito cosmopolita, eu tive a sorte de tocar vários tipos de música e experimentar com o violoncelo. Isso fez que eu tivesse que transcender os limites do violoncelo e a técnica que eu tinha aprendido, tradicional. Não dá pra tocar Jazz com a técnica erudita do violoncelo, não dá mesmo, ou vai ficar uma coisa meio híbrida, no meio do caminho.

Eu tive que ajeitar a minha técnica e transformá-la, para conseguir colocá-la dentro de outras estéticas, outras músicas. Seja jazz, ou música indiana, ou africana, ou improvisação livre. E a outra coisa que eu tive que fazer, que com certeza completou a minha formação, foi inventar uma linguagem, para tocar violoncelo de outra maneira. Para tocar violoncelo popular. Essa invenção de uma linguagem inteira me obrigou a quebrar barreiras e problemas técnicos.

Quando você quer tocar, por exemplo, com um saxofonista, rápido, com um monte de cromatismos, isso no violoncelo significa muita coisa, não é? Uma dificuldade muito grande, tocar rápido, num instrumento que não é tão ágil, mudar muito de posição, e inventar uma técnica de arco muito ágil, que consiga articular muito, como um músico popular, ou como na música antiga, hoje a gente sabe que se fazia, e, ao mesmo tempo, "suingar" com o arco, tirar um som diferente, articular com articulações diferentes que, justamente, dão esse suingue, não muito quadrado; então desenvolvi uma agilidade de arco muito pessoal, e acho interessante.

Minha formação foi essa, teve um lado acadêmico quase incompleto, pra falar as coisas de verdade, mas peguei o meu diploma de violoncelo, e outro lado, que era da vida mesmo, na raça, de aprender tocando e "comendo" o palco, porque eu trabalhei muito em Paris, muito. Então, dos dezoito anos até os vinte e cinco, toquei muito, fiz turnês gigantescas, trabalhei com muitas pessoas, gravei, estudei muito, do meu jeito, para eu ajeitar a minha técnica à música popular, no violoncelo.

\section{Você considera que teve acesso a uma base técnica e teórica suficiente? Se não, o que faltou, e como você superou essas carências?}

Acho que nunca é suficiente. Acho, como professor hoje, que nunca é suficiente, não há tempo para um professor passar todas as informações de que precisa, todo o repertório, toda a técnica necessária para uma violoncelista virar aquilo que ele vai 
virar, ao longo da vida dele. É praticamente impossível. É gigantesco o tamanho das informações que tem que passar para os alunos, para o aprendiz, de onde começar?

Por exemplo, só o repertório: o que você vai estudar em quatro anos de estudo superior, aqui no Brasil, na Universidade? O quê? Quatro anos não é nada! O repertório é gigantesco! Não chega uma vida para você trabalhar o repertório do violoncelo, como violoncelista profissional. Imagina: século XX, XXI, XVIII. Sonatas, concertos, solo, música de câmara, é gi-gan-tes-co. Nunca é suficiente.

De outro lado, minha formação acadêmica foi relativamente completa, tive muita sorte. Sempre me lembro dessa última professora minha. Ela me deu bases muito sólidas, disso que se poderia chamar "escola francesa" do violoncelo. Ela me deu algo muito interessante, acho muito importante todo professor dar para todo aluno, que é "como estudar". Dar um sistema, uma lógica, o porquê de fazer um dedilhado assim, e não "assado". Uma estrutura que tem uma tradição atrás. Ela não falava isso só dela mesma, era óbvio que era uma tradição de séculos, uma escola atrás dela, que falava: "Esse dedilhado a gente faz assim, porque facilita tal coisa, o arco assim porque tal...".

Ela me ensinou um pouquinho de estrutura, quando você faz algo tem que ter uma coerência, que eu aprendi muito com ela, e que achei muito proveitoso para o resto da minha vida como violoncelista: se você fizer um dedilhado assim, e vier uma coisa parecida depois, você vai fazer símile. Ou, você tem que ter uma coerência de som, você fez uma melodia numa corda só, quando ela aparecer numa corda mais grave, mesmo que seja mais grave, faz na mesma corda então, também. A coerência, que eu não sabia antes, aprendi lá em Paris.

Acredito que a resposta é dupla: ela foi completa, de um lado, e foi incompleta, pois é impossível ter uma formação completa. A formação só se completa com a experiência pessoal, depois. Tocando e tocando e trabalhando com pessoas, estudando sozinho, ampliando cada vez mais a exigência, estética e técnica, que você tem daquilo que você está fazendo.

\section{Você considera pertencer a uma escola violoncelística? Qual e por quê?}

Essa é uma pergunta difícil de responder pra mim, que eu toco tantos gêneros de música diferentes. Academicamente, mais formalmente, tenho essa forte influência francesa. Acredito que depois eu misturei as escolas, eu soube procurar ver os vários 
jeitos de tocar, eu sou muito aberto. Não acredito que tem que se tocar de um jeito só. Eu ampliei um pouquinho a minha maneira de tocar. Acho que a escola francesa do arco, que tem o pulso solto, continua sendo, para mim, uma referência. Quando eu ensino, eu defendo essa escola.

De alguma maneira, mesmo que eu ache que não é justo falar isso, acredito que ela é superior. Ela permite fazer com o arco coisas extraordinárias, ter o pulso solto, e não "tudo junto", como a escola russa, que a gente estava comentando, antes ${ }^{38}$. Ela permite muita articulação, agilidade, clareza, eloqüência com o arco, então, com certeza, com a Reine Flachot e com o Phillipe Muller, eu peguei muito esse lado da escola francesa.

Depois, acredito que fiz uma mistura, porque, tocando Jazz, tive que adaptar, inventar muita coisa e adaptar minha técnica a esse tipo de música. E ao improvisar, a minha emissão de som é muito pessoal.

Eu vi, depois, um violoncelista que eu admiro muito, nunca trabalhei com ele, mas ele me influenciou, e eu deveria, talvez, colocá-lo dentro da minha formação, indiretamente, por eu ouvi-lo "muuuito", - eu tenho muitos discos dele- e finalmente ter o prazer de conhecê-lo, e ir na casa dele, bater uns papos com ele, que é o Anner Bylsma. É o meu violoncelista preferido, para você entender um pouco o que seria a minha escola. Ele fala que ele tem mais a escola francesa de arco, mesmo ele sendo holandês... Ele tem essa coisa do "pulso solto", muita facilidade de articulação, que a gente usa muito, também, na música antiga.

O que eu poderia falar mais da minha escola? Eu acho que ela misturou, fora ser francesa, algumas características da escola, talvez, alemã e russa, porque eu uso muito o peso do meu braço para tocar, e tirar muito som. Eu tive que pegar tudo isso sozinho, porque fui confrontado com a realidade: eu tive que tocar.

Quando tive que tocar Jazz com uma bateria, com um saxofone, tive que tirar muito som do violoncelo. Foram coisas da vida que me fizeram tomar decisões e procurar achar soluções técnicas para os meus problemas reais: Como tirar som? Ou, como você vai se comparar, como você vai sobreviver, dentro de uma situação sonora em que você tem que tocar com um contrabaixo amplificado, com a bateria, que é um instrumento muito forte, com qualquer sopro, com muito mais som do que a gente?

\footnotetext{
${ }^{38} \mathrm{O}$ Professor Dimos se refere à conversa prévia, tida anteriormente à entrevista.
} 
Tive que trabalhar muito a emissão do som. Acho que eu misturei essa escola francesa do arco, que é mais leve e mais articulada, com o peso que você acha nas outras escolas. Ou seja, deixar o arco ficar na corda, por exemplo, e tirar muito som. E acredito que, de alguma maneira ingênua, fiz a mistura das duas coisas.

Eu acho, de verdade, que eu não tenho uma escola definida. Eu tenho uma, que a gente brincou, uma "holística", eu quero usar as coisas boas de todas as escolas, juntálas e fazer uma técnica, acredito eu, superior. Você poder ter todas as técnicas na mão, e usar um pouquinho de todas, oportunamente, seria, talvez, uma técnica superior. Ter a facilidade com todas, dominar todas, e fazer uma síntese, então. Isso seria o meu pensamento. Não sei se consigo isso, como violoncelista, mas é minha intenção. Juntar e usar as coisas boas de cada uma das técnicas, nas estéticas... porque cada escola tem uma estética também. Não é só técnica. Cuidado! É uma maneira de você pensar na música. É uma maneira de você executar, vibrato, non vibrato, enfim, milhões de coisas que vem aí, do lado estético, não é?

\section{Você acredita que uma determinada escola seja melhor? Para você existe o certo e o errado?}

Não. Eu acredito que não. Como professor, eu tive que redescobrir várias coisas, para poder explicá-las aos meus alunos, que para mim eram naturais, e isso também é um grande aprendizado. Você ser professor é uma nova escola, você está refazendo a sua escola, acho eu. Você tem que voltar para trás, explicar, entender a mecânica de algumas coisas que para você não têm mais importância, porque já estão funcionando. Eu acho, mas eu falo com todo o cuidado, porque eu já falei pra você que eu sou uma pessoa que quer pegar de tudo, que quer englobar, que quer achar que tudo é válido... Que todas as escolas têm uma experiência, tem uma tradição, e por isso só já são válidas.

Agora, com todo o cuidado, acho que a técnica dessa escola mais russa, ou alemã, que quer o braço mais uniforme, por exemplo, a mão direita, e não usa tanto o pulso, não tem o pulso tão solto, para mim, talvez, parece um pouquinho defeituosa. Acredito que temos articulações diferentes na mão, no braço, essa dos dedos, essa do pulso e essa do cotovelo, que têm que ser usadas. Dão muitas facilidades e uma multiplicidade de golpes e de sons e de detalhes nos sons e na articulação, maravilhosas, 
e que se perdem um pouquinho, se tocar só com o braço inteiro, sem nunca deixar o pulso solto.

Tenho uma tendência de achar que talvez a escola de arco francesa é mais expressiva, mais completa do que a outra, mas, de novo volto a falar que toda escola tem uma tradição muito respeitável. E razões de ser... e tudo tem prós e contras. Claro que sempre você ganha alguma coisa e perde alguma outra, quando você entra numa escola só. Pela mesma razão, eu acredito que tem que ter, hoje, uma síntese, uma junção das diferentes escolas, para ter uma técnica boa mesmo. Eu acredito que tem que saber tudo, dominar tudo, para depois você criar uma técnica superior. Aí isso seria uma escola melhor, para mim, do que as outras. Uma que engloba todo o mundo dentro.

\section{Como você segura seu arco? Por quê?}

(Risos) Eu vou falar uma historinha, uma parábola, que eu acho bem legal. Eu voltei, uns dois anos atrás, lá para a Grécia, e revi (sempre vejo, quando eu vou lá pra tocar, ou para ver a família) aquele professor búlgaro, que ficou meu amigo, que é o Russi Dragnev e, não sei o que foi que eu mostrei pra ele, a gente ficou lá tocando violoncelo e eu falei "ah, mas, e a posição... e, não sei o quê" e "quando eu seguro na perna", porque eu seguro na perna, "sem o espigão", e ele ficou me olhando... assim e me falou: "Dimos, eu não estou te reconhecendo...", e tirou o espigão, ele não toca barroco não, pegou assim, entre as pernas, e começou a tocar. Aí ele colocou o espigão mais longo, e começou a tocar muito, tudo! Aí colocou entre as pernas e começou a pular, assim, com as pernas e com o violoncelo! E a tocar e a mover o violoncelo à direita e à esquerda, a tocar muito bem, tudo afinado, tudo super...! "Então você acha que tem alguma importância em como você vai segurar o violoncelo?”

E, de verdade eu acho isso. Eu nunca dei muita importância nisso, como te falei, não tenho muita coisa muito acadêmica, assim. Mas ele me abriu os olhos naquela hora, e eu falei: "Opa, um cara acadêmico que fala isso, opa!" Quer dizer, damos muita importância em como segurar o violoncelo, em como segurar o arco... Acho que podemos segurar de qualquer maneira. Cada um também tem uma maneira de ser, um corpo diferente um do outro, a mão diferente, um tem braços longos, outro curtos, dedos mais curtos, outro é alto, outro é baixinho, quer dizer, pode tocar com espigão, sem o 
espigão, com o espigão gigantesco, outros com o espigão muito pequeno, parece quase que toca sem o espigão, na perna, com o violoncelo mais ou menos inclinado...

A única coisa que eu acho muito importante é não criar tensão no corpo. Não tocar com uma posição que te crie um problema corporal. Aí é um problema. Todo o resto é aceitável... e não acredito em nenhuma escola que fala que tem que se tocar assim, com tal posição fixa e tal. Eu acho isso uma prisão. Acho isso o pior defeito de todas as escolas: querer modelar o aluno dentro daquela maneira, especialmente quando se fala de posição. Tudo bem falar de estética. De som. De técnica. O resultado sonoro é super importante, e cada escola tem o que falar. Agora, como segurar o instrumento! Acho loucura impor ao aluno.

O único aspecto que não seria loucura é ver e detectar que o aluno está torto... que vai ter um problema corporal, que vai doer, não vai conseguir tocar, as costas, daqui a alguns anos vão estar um caos, aí, claro, tem que corrigir o aluno.

Agora, pra voltar nessa pergunta de verdade, eu seguro de várias maneiras, porque eu toco arcos diferentes. Não tem uma resposta única. E acho que é aí que vem, talvez, a fluidez que acredito que eu tenho com o arco. A facilidade; eu tenho mais facilidade, acho, como violoncelista, com o arco, do que com a mão esquerda.

Tenho que trabalhar mais a mão esquerda sempre, o polegar, afinação, do que o arco. Eu tenho uma naturalidade. É justamente de não ter uma escola muito fixa. Eu consigo usar o arco com o braço inteiro e com muito peso, eu nunca toco com tensão, nunca toco alto, sempre com o cotovelo baixo, com o ombro baixo, que é básico, acho, para não ter tensão e tocar com peso. Acredito que a emissão do som no arco, toda a arte do arco vem dessa junção do peso e da velocidade. Isso faz tudo, no arco. A velocidade e o peso resolvem tudo.

Eu seguro o arco de várias maneiras, porque no arco barroco eu pego mais dentro, não seguro no talão, que era a maneira mostrada nos métodos daquela época, para se segurar o arco. O arco clássico também, não se segura tanto no talão, e depois o arco moderno, que eu seguro no talão... eu tenho essa escola um pouquinho francesa, eu não pego... eu tenho o pulso nem totalmente reto, nem totalmente quebrado. Eu uso muito o peso.

Tento segurar o arco da maneira mais natural possível, então, quando eu ensino para um principiante como segurar o arco, deixo ele segurar o arco pela mão esquerda, 
mesmo, para o arco não cair, e colocar a mão direita mais relaxada possível em cima do talão. E aí os dedos, naquela posição que eles vêem, relaxados, acredito que seria a posição boa para ele segurar. A única coisa que parece não muito natural é o polegar, que vem, então, não relaxado, entre o segundo e o terceiro dedo. Não é verdade? Então é isso.

Eu não sou muito exigente no sentido do polegar ser "quebrado" ou não, reto ou flexionado. Eu uso mais reto, pra falar a verdade, mas nunca o deixaria fazer uma tensão, estendê-lo para dentro. Ou reto ou um pouquinho, assim, convexo. E sinto que uso muito os dedos para fazer os golpes de arco. Tenho um ponto fixo, eu sei onde os meus dedos estão, eu tenho, por exemplo, o pulso e a mão muito soltos, os dedos soltos, mas não tão soltos a ponto de perder o ponto de contato. Ele fica sempre lá, não vou perder o arco da minha mão, mas eu tenho muita mobilidade em torno desse ponto. Os meus dedos se movem à esquerda e à direita, conforme eu pego a direção diferente do $\operatorname{arco.}$

Ou eu quero fazer algum golpe de arco em que eu use só os dedos, por exemplo: nem pulso, nem braço, nem nada. Então a minha filosofia é gastar o menos energia possível, para fazer certos golpes. Se a nota é muito pequena, se é para tocar semicolcheia, uma coisa muito rápida, eu não vejo a necessidade de usar o braço inteiro, por exemplo, que usa a outra escola. Mas eu posso até usar, às vezes nem o pulso, fazer o golpe inteiro só com os dedos. É um gasto de energia e um movimento de massa, pela física, muito pequeno. Você não gasta energia, então. Talvez isso signifique uma certa agilidade, sem se cansar.

\section{Qual é a sua maneira de uso da mão esquerda? Por quê?}

Acho que também não é muito definida, especialmente a mão esquerda. Acredito que eu tenha mais definição na mão direita, da escola francesa do arco, junto com todas as experiências da música barroca e do jazz, essa coisa de articular muito com o arco. Não tocar muito legato. Isso dá muita diferença. Agora, a mão esquerda, tem que usá-la dos dois jeitos predominantes, que são: sem extensão e com extensão.

Tem duas escolas, assim, muito fortes, em que em uma você anda no violoncelo, tenta evitar extensões para não ter muita tensão na mão, não cansar. A outra tenta ficar o 
menos possível numa extensão e trazer, ao contrário, a mão inteira lá perto, para fícar relaxada. Eu acredito que as duas são super válidas.

Pela música antiga aprendi muita coisa, nos últimos anos, de mão esquerda, que nunca se usa mais, nos tempos modernos. De fazer dedilhados, por exemplo, alternativos, dedilhados de violino, fazer tom entre o primeiro e o segundo dedos, semitom entre o segundo e o terceiro, mais um tom entre o terceiro e o quarto, coisas desse tipo. Fazer extensões de todos os tipos, extensões também maiores do que se permite fazer, fazer do primeiro para o segundo dedo uma terça menor, esse tipo de coisa que pode ser útil para certas passagens musicais, para você resolver específicos problemas, passagens de peças específicas.

E, ao mesmo tempo, acredito que é muito válido também não cansar a mão. Você pular muito, mudar muito de posição, para chegar nos lugares certos. Eu misturo as duas coisas. Como sempre, eu estou nessa (risos)... de misturar várias experiências.

Eu toco com, sim, aí tem uma escola, que eu nem sei qual é, eu não toco com a mão virada, eu acho que, não sei nem falar muito bem se essa técnica é defeituosa, porque acredito que você não chega muito bem nas posições. $\mathrm{O}$ violoncelo é um instrumento muito grande. Eu acho que fica um pouquinho desconfortável você chegar na nota que você quer quando você está virado assim ${ }^{39}$, um pouquinho. Fica mais longe. Fica uma tensão suplementar para os dedos. E eu toco com a mão redonda. Sim. Aí sim, talvez tenha alguma coisa da escola francesa, de novo. Tento tocar e tento ensinar com os dedos paralelos ao cavalete e à pestana. E bem redondos.

E lá no polegar, lá em cima $^{40}$, acho que as duas coisas valem, você tocar redondo, mas às vezes é difícil, você tocar um semitom, tocar na corda, lá perto do polegar, é sempre difícil. Acho que é muito válido também você "quebrar" o dedo, como a gente faz, e virar, nesse caso. Lá no polegar é um pouquinho mais cômodo você tocar virado, digamos, com essa direção dos dedos olhando para o cavalete. Não é? Agora, aqui em cima ${ }^{41}$ acredito que fique menos tensa essa posição mais redonda. E é essa que eu uso, com certeza.

Dependendo da situação, faço muitas coisas não ortodoxas. Posso fazer extensões estranhas, é muito interessante. Tem algumas extensões, por exemplo, de

\footnotetext{
${ }^{39}$ Aqui o Prof. Dimos mostra a posição da mão esquerda inclinada, mais deitada, em direção ao primeiro dedo, ou com mais peso no primeiro dedo.

40 "Lá em cima" se refere, nesse caso nas posições mais agudas, nas quais se usa o capotasto.

${ }^{41}$ Refere-se às posições mais graves (primeira até a quinta).
} 
oitava, que podem ficar legais, - eu tenho a mão relativamente grande e eu consigo abrir muito - que podem ficar boas, justamente com essa posição redonda, e paralela ao cavalete. Mas, às vezes, descobri que, quebrando o pulso, virando-o pra dentro assim, e virando os dedos assim também ${ }^{42}$, você consegue fazer uma extensão muito grande. Então depende muito da situação.

Às vezes toco muitos acordes, tocando música popular. Eu consigo fazer pestana facilmente até com o quarto dedo. Nesse caso, você não toca muito redondo, você toca com a mão, de uma maneira meio grosseira, em cima das cordas mesmo. Posso pegar muitas cordas com o mesmo dedo. Então fica o dedo chato, mesmo. Você vê, depende muito da situação. Acredito que a melhor maneira, a que mais eu uso para tocar a música erudita, é essa da mão redonda e os dedos paralelos ao cavalete.

\section{Qual a importância do polegar da mão esquerda para você? Como você o usa?}

É um dedo muito importante, que deveria ser usado tanto quanto os outros. Obviamente é sempre um problema, sempre um desafio para o violoncelista. A gente tem... esse medo do polegar (risos). Mas, pra falar a verdade, eu uso o polegar o menos possível (risos). Onde é necessário usar, claro, tocando o repertório erudito, tem de usar onde se usa, mas quando improviso, por exemplo, não uso tanto o polegar.

Acredito que seria bom ter a mobilidade do polegar e poder usá-lo até aqui, nas posições graves, nas primeiras posições do violoncelo, como um dedo suplementar. Não é muito cômodo. Mas pode ser usado pra situações excepcionais. Obviamente é uma facilidade grande poder usar o polegar como um quinto dedo. Você tem um dedo suplementar na mão. Você pode fazer coisas maravilhosas, extensões gigantescas, chegando o polegar até uma nota muito aguda, com o quarto dedinho, ou com o terceiro dedo. Ele permite essa coisa de você transitar no braço inteiro ${ }^{43}$, não tenho a menor dúvida, ele tem de ser usado o máximo possível, com a maior facilidade possível e a maior mobilidade. É muito bom poder trazê-lo em cima do espelho com muita facilidade.

Também acho que tem de ser um dedo que não faz pressão, contra a pressão quando a gente toca com a mão esquerda normal, lá em cima ${ }^{44}$. Acontece muito e isso

\footnotetext{
${ }^{42}$ Refere-se a inclinar a mão toda para o lado do indicador, com as pontas dos dedos voltadas para o cavalete e o pulso quebrado para baixo.

${ }^{43}$ Refere-se aqui, ao braço do violoncelo.

${ }^{44}$ Nas primeiras posições mais agudas do violoncelo.
} 
dá muita dificuldade à mão esquerda. Quanto mais duro o polegar, mais difícil fica a mobilidade da mão esquerda. A mão inteira é atrapalhada pelo polegar, que fica lá, durinho, atrás, fazendo força.

Quanto menos apoio, mais relaxado fica o polegar atrás do braço, melhor. Você facilita muito mais as extensões, claro, porque o polegar vai junto com a extensão; quando você abre, por exemplo, do primeiro para o segundo dedo para fazer um tom: se o polegar ficar fixo lá atrás, onde ele estava, a extensão vai ser dificultada. Se o polegar anda junto com o segundo, ou o terceiro ou quarto dedo, abrindo, obviamente você facilita a abertura. Menos tensão, com certeza, para tocar.

Aquilo que eu te falava de poder trazer o polegar em cima do espelho com facilidade, com naturalidade: tem uns exercícios muito interessantes, muito alternativos, que o Anner Bylsma me mostrou, de, por exemplo, usar o polegar como usam os pianistas. Por incrível que pareça. Então, quando você está lá em cima, nas posições agudas do violoncelo, e você está em cima do espelho, com o polegar, poder passá-lo (risos) em baixo dos dedos, para pegar uma nova posição de polegar. É muito interessante. Não que, especialmente, alguém vá usar, mas é uma mobilidade, um relaxamento desse dedo, muito interessante de ter, para poder, depois, tocar.

Nas posições graves, eu posiciono o polegar mais ou menos entre o primeiro e o segundo dedos. Não deixo muito atrás, porque ele dificulta as extensões, para chegar nas notas. Acredito que há uma semelhança grande, um mimetismo entre as duas mãos, no violoncelo. É praticamente a mesma coisa que a gente faz. É a mesma posição, o polegar vem entre o primeiro e o segundo, ou entre o segundo e o terceiro, no arco, e a mesma coisa acontece aqui na mão esquerda. Também esse movimento que é "para cima e para baixo" na mão esquerda, no violoncelo, é o mesmo, só que horizontal, no arco. É muito parecido o que a gente faz com as duas mãos.

\section{Você acredita que devemos ter uma "forma de mão"?}

Não, eu não acredito que devemos ter uma forma fixa. Sinceramente não. Mas, acredito que podemos usar todas as formas tradicionais que se usam por aí. Sempre acho, quando eu ensino, que tem que tocar relaxado. Obviamente a forma da mão pode ajudar, nesse sentido, de não ter tensões. Se você tocar com o ombro muito alto, você está tenso, obviamente. Se você tocar com o cotovelo muito alto, você tem que segurar 
a mão no ar e isso é muito cansativo, cria tensão muscular. Então você tem que tocar relaxado.

Nesse sentido, sim, tem alguma forma da mão, alguma redondeza, acredito que não tem que tocar muito "anguloso". Não tem que estar com, por exemplo, o pulso nem muito pra baixo, muito para dentro, nem muito pronunciado pra fora, para cima, digamos, porque são tensões desnecessárias. Eu poderia falar de uma forma mais redonda e mais relaxada da mão, mas, conforme a situação, você pode tocar com os dedos mais chatos em cima da corda, fazendo pestanas, pegando mais grosseiramente, digamos, ou mais redondo.

Eu não acho que o tempo todo tem que tocar com aquilo que falavam antigamente do ovo ou da bolinha dentro da mão... é muita prisão, uma visão muito fechada. "Sempre tem que estar assim", ou "sempre tem que estar assado", você fica mais com a preocupação de como está tua mão, do que com a preocupação musical de como você está tocando. Certo? Tem que saber dosar as duas coisas.

\section{Para você os dedos da mão esquerda devem estar sempre abertos em uma posição enquanto tocamos, ou não, esta posição deve ser adaptável e relaxada?}

Ela é adaptável, sim, e relaxada, com certeza. Porque o relaxamento é o mais importante. Existe um problema físico de tocar violoncelo, ou qualquer instrumento, que é o cansaço físico mesmo. É muito pesado, é um instrumento grande, as cordas são grossas, é muita tensão para abaixá-las, então, o mais relaxado é o melhor.

Claro, acho que é bom você mostrar ao aluno para ficar o mais perto da posição que está tocando, com todos os dedos, para não perder a referência e não perder a afinação. Mas, ao mesmo tempo, esse tipo de professor que fica falando que tem que colocar os dedos numa corda, num lugar, e ficar tirando um por um os dedos, para colocar na próxima corda, quando você toca... é muita loucura, é muita tensão. Acho que tem que relaxar os dedos, tocar com aquele dedo que você está tocando, e deixar o resto lá por perto, mas relaxado.

Tem professores que falam: "não, você está tocando aqui na corda ré, e todos os outros dedos estão no lugar na corda sol”. Que loucura! Que tensão, você imagina? É muito complicado. É sempre o equilíbrio que tem que achar entre o relaxamento, e, ao mesmo tempo, não perder a posição, a afinação, nem a referência. 


\section{Como é seu estudo diário? Existe uma rotina? Existe uma programação prévia?}

Às vezes. Depende, também. Minhas respostas são sempre dúbias (risos). Existem períodos em que eu falo: "tenho que estudar aquilo, porque eu tenho tal concerto, tenho que preparar aquilo", ou eu tenho alguma organização prévia do estudo, em que eu preciso estudar tal peça e tal peça, até o concerto chegar, por exemplo. É uma situação profissional, mesmo. Entro dentro de uma programação, para conseguir fazer aquela peça.

Não tenho um programa muito fechado, a gente viaja muito, como músico. Viajo muito, logo o meu estudo às vezes sofre um pouquinho, ou você está na estrada, ou num hotel, ou está passando o som, é sempre complicado de estudar, como você estuda em casa. Mas eu tenho uma disciplina, gosto de estudar, e tento estudar todo dia. Eu gostaria de estudar todo dia, algumas horas; não tenho um horário fixo, mas queria ter esse programa de estudar todo dia, sim.

A única maneira de se tocar música, de segurar a técnica, de ampliá-la e de fazer melhor, é estudar todo dia mesmo, o máximo possível. Disso eu não tenho a menor dúvida. Eu não acredito nessa coisa assim, do gênio... tem alguns caras aí que aos cinco anos de idade tocam o Concerto do Tchaikovsky, bom! Não sou desses. E a maioria das pessoas não é. Então não falamos dessas pessoas excepcionais, isso é outra coisa...

Acredito que a música seja, talvez, a coisa mais completa que o ser humano inventou, é um desafio gigantesco. Tem que estudar o máximo possível, quase uma disciplina de atleta. Tem essa coisa física, você segurar o corpo, os teus dedos irem no lugar, cada vez, tocar afinado. Você tem que malhar, estudar, todo dia, fisicamente ter essa força. E tem todo o lado estético, toda a memória musical, aprender o repertório, que é gigantesco...

Você tocar afinado no violoncelo não é brincadeira! Sempre colocar o dedo no lugar certo, em qualquer posição, no meio desse espelho preto, no meio do nada, é uma precisão histérica, que só pode ser trabalhada diariamente, o máximo possível, pra você sempre conseguir. É muito complicado. Então, eu estudo o máximo possível, todo dia. 


\section{Para você o que é mais importante a se buscar e pensar, no estudo diário?}

Depende da situação. Em meu estudo diário, tento ter um lado de disciplina mesmo, estudar escalas, arpejos, coisas técnicas. Sempre procuro também transcender algum problema técnico que eu tenha. Ir mais longe. Com certeza tenho, todos os últimos anos, como hábito, não só estudar aquilo que eu tenho que tocar, mas ir mais longe tecnicamente.

Também muita coisa que eu procuro do lado estético. Como tocar uma nota bonita, como fazer um crescendo, um decrescendo. Estudo tudo isso, do meu jeito. Invento muito para estudar, meus próprios exercícios, improviso muito estudando, para resolver os meus problemas técnicos, ou problemas técnicos específicos daquilo que tenho que aprender, naquela época, para tocar.

Com certeza, buscar, transcender, ir mais longe, tecnicamente. Fazer coisas mais e mais difíceis, cada vez. Mais e mais precisão. Trabalho muito a afinação, muito os pulos, os grandes intervalos, trabalho muito o meu arco, o som, a emissão de som... posso ter, às vezes, em períodos longos, ou mais curtos da minha vida, uma disciplina de sempre esquentar fazendo escalas ou arpejos, ou pegar mesmo alguns estudos de violoncelo, repetir coisas, trabalhar o Duport, ou o Popper, e aí sempre tem um lado mais prático, mais pragmático, porque eu sempre tenho que tocar muita coisa.

Toco música popular, erudita, barroca. E tem muito concerto, sempre. Ou seja, tem um lado obrigatório de aprender aquele repertório, ou tocar melhor, ou segurar, no sentido físico mesmo... por exemplo, três dias atrás, toquei três Suítes de Bach, faz 20 anos que eu toco Suítes de Bach! Então não é mais um problema de tocar notas, ou arcadas, conheço bem o texto. Mas é, às vezes, físico, como agüentar tocar num recital três Suítes Solo de Bach, sem cansar, sem estressar, segurando sempre a concentração.

Às vezes, nesse nível agora, aos trinta e sete anos de idade, o estudo nem é técnico. Pode ser mais profundo, tentar estudar, durante um longo período da minha vida, como que seria, por exemplo, tocar uma peça inteira como num concerto, mas aqui no meu quarto, com a mesma intenção, a mesma densidade, o mesmo sentimento. E ao mesmo tempo, controlar minha emoção, para poder tocar perfeitamente, tecnicamente. Isso é um estudo diferente.

Ou, tentar me colocar no lugar do público. Ao mesmo tempo em que eu toco, envolvido na música, com toda a emoção, eu conseguir sair fora e ir lá do ouro lado, do 
público, mesmo que não tenha público, e me ouvir com muita atenção. Ter muita consciência daquilo que eu estou fazendo. Não estou só estudando coisas técnicas, como vou tocar essa passagem, como vou tocar um Dó Maior afinado, não é?

Estou estudando outras coisas, agora. Minha postura no palco, isso de poder ouvir de fora, ouvir de verdade, de uma maneira crítica aquilo que estou fazendo. São milhões de coisas. Tento sempre diversificar muito, porque fico cansado facilmente da repetição. Sou uma pessoa que não gosta muito dessa coisa de "todo dia a mesma coisa". Tem períodos em que faço todo dia a mesma coisa, depois tem outros em que mudo e foco em outra coisa. Tento focar o tempo todo no máximo de coisas possível.

Sou assim, não acho que é um exemplo para todo o mundo, às vezes a gente tem que ficar focado numa coisa. Mas eu não consigo focar só na música erudita, como profissional. Toco música popular, toquei música contemporânea, música barroca, música clássica, toco instrumento com corda de tripa, com corda de metal.

Dentro dessa realidade minha, tenho que impor isso, tenho que estudar tudo isso. Tenho que estudar um instrumento antigo ou um instrumento moderno, o repertório moderno para passar para meus alunos, o repertório antigo, para tocar profissionalmente, arco moderno, arco barroco, arco clássico, Jazz, improvisação, uma linguagem toda diferente, tenho que fazer tudo isso, ao mesmo tempo. Então o meu estudo é muito diversificado.

Ao mesmo tempo, não tenho nada de anárquico, dentro dessa loucura, cuidado! Tenho uma maneira metódica de separar as coisas, de falar: "nessa hora eu vou estudar isso, aquilo depois, e aquilo depois".

\section{Você faz tudo o que seus mestres pregavam? Algo foi adaptado? O quê? Por qual razão?}

De novo uma resposta dupla. Eu uso tudo o que eles me ensinaram, acho que eu usei de alguma maneira, mas incorporei e transformei, numa coisa minha. São as duas coisas. Achei tudo o que eles me falaram válido, tudo é aproveitável. Claro! Obviamente as aberrações, uma coisa totalmente errada, a gente fala que é errado e acabou. Uma coisa torta, o cara tocando torto... Tudo o que tem uma escola, uma justificativa, uma estética, mesmo que não seja a sua, é válido. 
O mundo é aberto. A música é alguma coisa livre. Não é uma religião. E nem a maneira de ensiná-la, nem de tocar, pode ser uma religião. É errado! A música é livre, é uma expressão humana, ela é feita do mundo inteiro, em todas as épocas, em toda a história da humanidade. Como alguém pode esperar que, na China do século XIII, se fizesse música com a mesma maneira, com a mesma técnica, ou com a mesma estética que... nos Estados Unidos do séc. XXI? É ridículo!

Acho que tudo é válido. Eu usei, acredito, tentei tudo o que meus professores falaram, cada um com sua experiência, um com a escola russa, outro com a escola francesa, outro com "a tal estética", tudo eu tento assimilar e colocar dentro de mim, e obviamente, transformá-lo na minha coisa. Acho triste fabricar alunos que ficam só repetindo aquilo que você falou. Terrível! É tudo o que eu não quero fazer, tudo o que eu quero ir contra, como filosofia na vida. Eu sou pró...diversificação. Eu acho que o diferente é que é o interessante, não o igual.

Essa época que a gente vive hoje é uma época abominável! De globalização, de fazer um gosto igual para todos. Uma maneira igual de pensar, de comer, falar a mesma língua, o inglês, eu acho terrível. A diversificação é que dá pimenta, interesse na nossa vida, não é?

A mesma coisa para a música, as estéticas diferentes, as técnicas diferentes... E isso se faz muito na música erudita, infelizmente. Sofri muito com isso em Paris, por isso tive essa negação, no começo, com meus estudos. Foi muito negativo. Em vez de me ajudar... Esses caras tão frios, tão duros, tão seguros da técnica deles, me fizeram abandonar a música erudita (risos), em vez de ir mais fundo, e eu querer virar um jazzista. Completamente o contrário do resultado que eles esperavam, sendo bons professores. É para se perguntar: são ou não bons professores? Um bom professor é aquele que consegue pegar o cara, e... Sofri muito com isso.

Essa coisa do Conservatório de Paris, ou qualquer escola super famosa do mundo inteiro, seja mesmo para o Jazz... a famosa Berkeley: sai um monte de pessoas que tocam da mesma maneira! Você ouve a pessoa improvisar, a gente quase ria, no Jazz, com meus amigos jazzistas, de falar: "o cara estudou na Berkeley". Quer dizer, improvisa da mesma maneira que todos aqueles... um monte de caras, um serviço militar inteiro, tocando da mesma maneira. Quer dizer... 
No Conservatório de Paris, os caras saíam tocando exatamente como o professor. Cadê a personalidade? Acho que o mais importante é fazer a síntese de tudo o que os professores falaram e modificá-lo, conforme são tuas exigências técnicas, estéticas... a música que você quer tocar, a maneira de tocar, o som que você quer ouvir, de você. Obviamente a gente tem que transformar, não fazer igual ao professor. Se inspirar, para fazer a nossa coisa. Senão, o músico não tem mais personalidade. Toca perfeitamente bem, super legal, mas não faz a mínima diferença do outro.

A única maneira de deixar alguma marca no mundo da música é ser pessoal. Ser você mesmo. E aí não tem como só ficar imitando o professor. Impossível. Você tem que transformar numa coisa tua.

\section{Você se preocupa em testar novas idéias divergentes das suas?}

Claro, o tempo todo. Tento ser uma esponja, um camaleão. Pegar de todo mundo, aproveitar, aprender técnicas diferentes. Estou em contato, de vez em quando, com violoncelistas alternativos, porque eu também toco esse tipo de outras músicas.

Eu vi, outro dia, uma violoncelista sentada no chão tocando violoncelo "indiano", com cordas simpatéticas. Ela achou uma maneira de sentar no chão, como os indianos fazem, e colocar o violoncelo - um violoncelo um pouquinho menor - e ela coloca um pano que fica segurando o violoncelo pelo espigão, e aí não escorrega para frente... eu achei incrível. Experimentei a posição, é interessante poder tocar no chão, dependendo da situação. Não, obviamente, para música erudita, mas para tocar outras coisas. Eu acho muito interessante essas técnicas, tudo o que eu vejo de novo.

A única coisa que eu não consigo muito entrar nesse mundo, não por não gostar ou por ter alguma crítica, é o violoncelo elétrico, e todas as possibilidades que pode ter, de pedais, e de coisas que... eu não conheço (risos). Não tenho tempo pra conhecer (risos).

\section{Você se preocupa com tensões no corpo? Sente alguma? Elas atrapalham ou atrapalharam de alguma maneira a sua execução? Faz ou fez efetivamente algo para melhorá-las?}

Não me preocupo mais. Tenho essa felicidade. Acho que toco muito relaxado. Eu não tenho tensões. Não tenho nada doendo. Às vezes, posso lidar com o cansaço 
físico de tocar muita coisa, como eu te falei, de tocar três Suítes de Bach. Pode ser um pouquinho cansativo. Claro que, ali, deliberadamente mesmo, pensando mesmo no assunto, acho algumas maneiras de relaxar, no meio da peça. Acho alguns pontos de apoio, momentos em que posso dar uma relaxada no polegar, ou na mão inteira, uma respirada, para poder continuar.

Graças a Deus, achei uma maneira de tocar muito relaxada. No passado, tive que lidar com tensões, como todo mundo, me lembro que passei anos, mais jovem, com aquilo de doer um pouquinho as costas, como acho que a maioria dos violoncelistas têm, pela posição.

Em um momento na minha vida, fiz uma troca com um aluno meu, que aprendia violoncelo, e ele me ensinava tai-chi. Acho que, sem querer, sem eu saber muito bem, ajudou o meu corpo, e a minha posição, a minha postura geral. Talvez isso, sem eu pensar muito no assunto, ajudou também a postura do violoncelo.

Com certeza, coisas que ajudam o relaxamento, e, ao mesmo tempo, a concentração interior, como a yoga, o tai-chi, as coisas orientais tem uma junção dessas duas coisas, ou da meditação. Você poder concentrar a força e mandá-la para certos membros do corpo, é muito interessante, poderia ajudar muito os instrumentistas. Eu não tenho nenhuma receita, não continuei fazendo tai-chi, não tenho muito tempo, mas me ajudou muito.

Essa coisa quase mística na maneira de tocar: como você acerta sempre aquela nota? Tem a memória cinética, do movimento. A memória manual... mas tem algo que é interior, de segurança interior. Que é visualizar, imaginar e ter muita certeza daquela nota, e ir naquela nota, simplesmente. Que, se você fizer o mesmo movimento, exatamente, com a mesma memória cinética, mas sem a segurança interior, se tiver algum momento em que você vacilou, que você falou "ai, aquela passagem,... eu vou...", você vai errar.

Tem algum outro lado, que não é só técnico, que não é só físico, que a gente pode trabalhar com a meditação, ou com a concentração interior, essa segurança, que ajuda você a acertar aquilo que você quer fazer. 


\section{O que você acha sobre a idade em que alguém deve iniciar seus estudos de violoncelo? O que você acha da realidade brasileira em relação a esse assunto?}

Isso é um assunto muito complicado. Sempre existem exceções na vida, sempre. Você não pode falar para alguém que quer começar o violoncelo aos vinte anos de idade: "Não, você não pode, você não vai virar um violoncelista!” É terrível! É fascista. Você vai cortar, talvez, uma pessoa que, você nunca sabe, poderia ser um talento extraordinário, ou ter uma maneira muito pessoal de se desenvolver dentro da música, um caminho também pessoal, porque nem todo mundo precisa ser o melhor violoncelista do mundo para ser violoncelista, para ser músico.

Nem precisa trabalhar na orquestra. Tem vários caminhos na música. Tem várias coisas que se pode fazer. Pode virar professor, fazer musicoterapia, tocar músicas alternativas, só improvisar, ou virar um maravilhoso violoncelista erudito, mesmo começando aos vinte anos de idade. Obviamente, isso é excepcional. Tem o outro lado. Tem realmente uma dificuldade muito grande, quando se começa a estudar um instrumento tão difícil e tão físico, como o violoncelo, tarde. É um problema físico.

Acredito que pessoas que já tem dezoito, vinte anos de idade, já são formadas. $\mathrm{O}$ corpo é formado. Talvez seja mais duro e um pouquinho mais difícil amolecer o corpo, para fazer todas as coisas que a gente faz, que não são muito naturais, não é verdade? Tem a força dos dedos que, se você não adquire muito pequeno, é mais difícil depois, fazer extensões, abrir muito a mão, talvez seja mais difícil em uma pessoa que não se acostumou, que não exercitou o corpo quando estava mole, quando estava jovem.

O corpo ainda se modifica, você está crescendo... quando você é ainda uma criança, com oito a dez anos de idade, pré-adolescente, você está crescendo, seus ossos estão mudando, sua estrutura corporal está mudando. É obviamente mais fácil você impor, ou ensinar alguma coisa, que o teu corpo vai aprendendo mais fácil, naquela época, do que depois.

Isso não tem solução. Com certeza é mais fácil começar mais jovem. Outra coisa, que todo mundo sabe, eu nem acredito tanto nisso, que uma criança tem a cabeça mais limpa, mais virgem, tem mais espaço para aprender, mais facilidade, mais rapidez, mais tempo também. Tem esses problemas básicos.

Quando você começa tarde a estudar um instrumento, tem que batalhar muito contra teu corpo, contra o tempo que você não tem, a disponibilidade da cabeça. Um 
adulto nunca vai ter tanto tempo quanto uma criança pra se dedicar ao estudo de um instrumento,... ele é adulto, tem que pagar as contas (risos), tem que dar atenção à família, ao namorado, à namorada, e a uma vida que não permite essa dedicação absoluta.

Claro, tem sempre o outro lado. Uma criança não tem a mesma maturidade de uma pessoa de dezoito anos de idade. Alguém que começa aos dezoito tem, talvez, uma estética, um gosto já formado, que pode permitir tomar decisões estéticas quando estuda o instrumento, mais facilmente do que uma criança. Tem sempre uma compensação do outro lado.

A realidade brasileira é muito problemática. Falando de um jeito meio... descarado, meio direto, mas que até me atrapalha. Por que eu sou um estrangeiro que está aqui no Brasil, que quando cheguei aqui vi esse potencial inacreditável do Brasil. Inacreditável, especialmente com a música. Um país muito musical, as pessoas muito talentosas, fazendo música com uma facilidade desconcertante! Do outro lado, tem muitas lacunas no país, tem vários problemas. Especialmente com a música erudita, que não tem uma tradição, não tem um ensino muito bem organizado, não tem instituições, não tem dinheiro para isso. É muito carente. De todos esses lados.

O ensino na Universidade é muito carente, falta muita coisa, especialmente tradição, mesmo, dinheiro, estrutura, infra-estrutura, mas falo de tradição. A realidade brasileira é muito complicada. Muita gente começa tarde o instrumento. De verdade, eu chego a falar com meus alunos, sem nunca querer apavorá-los, coloco esse problema na cara deles, em algum momento, não no começo, que é: “o que é que vocês querem fazer com o violoncelo?"

$\mathrm{E}$, nessa idade, especialmente: “O quão rápido vocês vão avançar, e qual a visão de vocês do que vocês vão fazer com isso, profissionalmente?"; "Tem um espaço para vocês trabalharem, ou não?". No mundo que a gente vive, inteiro, aberto, não só no Brasil, é muito complicado. Primeiro porque o mercado é muito saturado, a arte não tem mais muito espaço no mundo que a gente vive.

Fora o lado comercial, que todo o mundo está cansado de saber. Tem muita gente tocando muito bem, a competição é cruel. Aqui no Brasil, acredito que ainda tenha um pouquinho de espaço, porque está todo mundo no mesmo nível. O ensino da 
música erudita no país não é muito avançado. Então todo mundo tem mais ou menos as mesmas chances.

Agora, se você quer se comparar, se você está imaginando que vai fazer carreira no mundo da música erudita, é muito complicado, começando tarde. E ainda estudando num país que tem tanta carência no ensino e na tradição dessa música. Ao mesmo tempo, isso pode ser uma vantagem, porque pode te dar uma força interior extraordinária, para você superar todas essas dificuldades e lacunas. Não é por acaso que sempre aparecem músicos brasileiros extraordinários, mesmo na música erudita. Gênios. Que transcendem... mas como? Porque tiveram que batalhar muito mais do que os outros, para conseguir aquilo que conseguiram. Então viram pessoas muito sólidas.

Sempre há uma desvantagem e uma vantagem também. Você tem que achar um potencial criativo, dentro de você, muito grande, pra você passar por cima de todas as lacunas que tem no país e você virar um artista. Mas acredito que a realidade brasileira é muito complicada no ensino da música erudita, hoje em dia. Eu fíco o tempo todo atrapalhado, lá na Universidade, na UNICAMP, o tempo todo batendo nessa tecla aí, falando muito com meus colegas, é um problema verdadeiro: muita gente chega lá, pra entrar no Terceiro Grau de educação, com dezoito anos então, com um nível muito básico no instrumento, que seria na Europa o nível principiante, de começar no conservatório da esquina do teu bairro, quando se tem dez anos de idade. É muito complicado. Eu fico angustiado.

Como formar uma pessoa, que praticamente começa o instrumento no primeiro ano da universidade, já com dezoito anos de idade, e que vai ser formado quatro anos depois? Teoricamente, isso não deveria ser aceito. Para alguém que vem da Europa, que tem essa bagagem que eu tenho, eu não poderia fazer isso. Não poderia formar, seria desonesto. Primeiro porque não tem a bagagem e a formação que deveria ter para ser formado, depois de quatro anos. Não dá para ter. Segundo, porque, como eu vou ligar o meu nome de professor com pessoas formadas, que são medíocres... Não medíocres como pessoas, mas que não tem, coitados, não tem o tempo e a bagagem suficientes, não é?

Depois vem o dilema: eu estou nesse país. Como vou fazer? O que é que se vai fazer? Não vai aceitar nenhum aluno, nunca? Não pode também. Você tem que dar a chance para esse pessoal de estudar música em algum lugar. Aparentemente, o único 
lugar, ou dos únicos lugares pra se estudar música, gratuitamente no Brasil, é na Universidade. Não tem outro. Conservatórios, não tem. São muito poucos. Escolas particulares são particulares, e os pobres, o que fazem? Não podem estudar música?

É um problema verdadeiro. Você tem que aceitar pessoas, para estudarem na universidade, porque senão você não permite ao país de ter acesso gratuito à música, e tem que achar esse equilíbrio de: como você vai formar essas pessoas, e como elas vão entrar no mundo profissional, com tão pouco preparo?

Não tenho uma resposta, uma receita maravilhosa, para resolver o problema do Brasil, mas essa seria a minha resposta: é uma situação problemática. Mas, dentro dessa situação existem as vantagens dela, por incrível que pareça. Justamente, por não ter educação muito boa, por não ter tradição, não está tudo pronto e oferecido dentro de um prato, mastigado, para as pessoas. Então elas têm de fazer um esforço gigantesco, e quem consegue sobreviver vira uma pessoa muito sólida, e por conseqüência, um músico muito sólido.

É aquilo que se fala, filho de rico, que tem tudo pronto, não faz nada na vida. E aí, filho de pobre, que tem que batalhar e que faz um monte de coisas, vira uma pessoa legal. Se pensar bem, um filho de rico deveria virar uma pessoa brilhante! Porque tem a facilidade de ter tudo. Mas não é. Aqui acontece mais ou menos a mesma coisa. Um grande potencial humano, pessoas que se viram sozinhas, e, por se virarem sozinhas são muito criativas, e muito diferentes. Talvez não toque tão bem como aquele que saiu do Conservatório de Paris, mas tem uma personalidade, na maneira de tocar, que é superior àquele, do Conservatório. E consegue fazer carreira. Sempre tem duas respostas. Ou mais. (risos)

\section{Quais as maiores carências dos alunos brasileiros, em sua opinião?}

É mais uma carência de tempo, de estrutura, de escola, e, de verdade, não se cria uma escola. Aqueles que ensinam hoje são aqueles que foram ensinados mal, ontem. É algo que muito dificilmente vai mudar. Tem que ter muita paciência, perseverança, não há uma estrutura bem definida para o ensino da música erudita no país. Obviamente esse é o maior problema, para um aluno brasileiro. 


\section{O que poderia ser feito para melhorar a realidade brasileira?}

Muita coisa! Coisas grandes, de país, básicas, por exemplo: na nossa situação de Universidade, a gente imagina que seria muito bom ter aulas de extensão. Criar lugares alternativos para se estudar, antes de entrar no ensino superior, e se formar. Para ter uma preparação mais sólida. Tinha que ter conservatórios, aulas de extensão, professores capazes, uma estrutura, colocar mais dinheiro na educação nesse país. Claro! Os mesmos velhos problemas. A cultura e a educação são os que mais sofrem nesse país, como em todos os países do mundo, nesse momento.

No Brasil, que não tem nem o básico... o mundo inteiro está virando essa coisa, capitalista, não se interessa na cultura, no ensino e na educação. Mas, no mínimo, na Europa eles tinham uma estrutura que vem de séculos! O Conservatório de Paris existe desde 1790! Então, por mais que o mundo vire essa coisa que a gente não gosta, existem lá instituições que tem tradição e que continuam funcionando dentro daquela tradição.

Aqui, como não existe isso, ainda o mundo virando essa coisa, que não dá atenção em tudo isso, é muito complicado. Não vejo como, exatamente... acredito muito no potencial humano mesmo, no potencial de cada um, de achar um caminho, e fazê-lo sozinho. Não acredito muito nas instituições. Não acho que milagres vão acontecer no Brasil, que vão fazer Conservatórios inacreditáveis, maravilhosos, de repente, Universidades... acredito que não. Se quiser ser realista.

Tem que jogar nesse lado pessoal. Aí está o papel do professor: poder detectar a personalidade de cada um, ver cada um, como ele reage e trabalhar com cada um, naquela relação mais antiga, antes das instituições, aquela relação privilegiada de mestre para aprendiz. Onde cada aprendiz, cada aluno é diferente. Você tem que encará-lo diferentemente, adaptar a tua maneira de ensinar, para tirar o melhor possível dele. Não é uma coisa massiva. Não é uma coisa de método, instituição: “eu vou ensinar sempre assim, todo mundo tem que tocar isso e aquilo".

Ainda pior aqui no Brasil, que não tem uma regularidade. Um tocou três anos, outro tocou só um, outro tocou quinze, antes de entrar na Universidade. Então você tem que se adaptar e contar com a força pessoal do aluno, para ele passar por cima de todas as lacunas, de todos os problemas do país e fazer o caminho dele por si mesmo, talvez com a ajuda dos professores que ele vai ter. 


\section{Você acha que a musicalidade só se evidencia após o aprendizado sólido de bases técnicas e teóricas?}

Não. A musicalidade tem que ser trabalhada simultaneamente com a técnica. Desde o começo tem que se pensar em musicalidade e em interpretação. Isso faz parte da técnica. $\mathrm{O}$ erro mais básico, que foi feito no ensino tradicional, na música erudita, foi dissociar o lado artístico, o lado da criação, da interpretação e da estética, do lado técnico. Fica puramente, friamente técnico. É o que faz muita gente abandonar, não querer trabalhar. Acho que as duas coisas andam juntas.

E o que é uma pessoa que toca bem? Não é uma pessoa, obviamente, que toca só perfeitamente tecnicamente. E que não fala nada. Uma pessoa que toca bem é uma pessoa que toca bem. Que toca o coração e você chora quando ouve, isso é tocar bem. Não é tocar rápido e perfeito, tecnicamente. Não é. Um monte de gente tem "dez dedos" e trabalha super bem, toca bem. Um monte, centenas, milhões de músicos no mundo. Mas não fazem diferença nenhuma. Você conhece eles, todos? Não. Porque conhece um, e aquele outro? Porque ele tem alguma coisa especial, que não é a técnica.

Acredito que tem que ser trabalhado simultaneamente, desde o começo. Não tem essa de "primeiro você aprende a tocar certo a escala, depois a gente vai falar de interpretação". Não, é ridículo! Fica muito atrasado no lado estético, interpretativo. De repente sabe um monte de coisas de técnica, de dedos e não sabe tocar duas notas, não sabe frasear, não sabe se vibra ou não. É terrível!

É uma lacuna terrível. Tem que ser trabalhado desde o começo, mesmo com crianças. Tem que falar de interpretação. Você vai falar tão simples de interpretação e de estética quanto de técnica, quando alguém começa.

\section{Como você constrói a interpretação uma obra musical?}

Isso é algo complexo, construir uma interpretação de uma obra musical. Eu tenho essa visão histórica da música erudita. Eu tento situar a peça dentro do contexto histórico dela. E, obviamente, aí existem os códigos prontos, para mim. Eu não vou tocar música alemã do século XIX da mesma maneira que eu vou tocar música italiana do século XVIII.

Existem alguns códigos prontos, que eu trabalhei ao longo de todos esses anos de trabalho com o instrumento e da minha maneira de tocar. A música barroca tem toda 
uma estética, e ainda, dentro dessa música barroca tem vários estilos, vários países, lugares. Tem o lado do compositor, onde ele nasceu, em que tempo ele viveu, que tipo de estética convém. Brahms é Brahms, Vivaldi é Vivaldi, Bach é Bach. Depois, tem as características de cada peça.

Acho que trabalho de uma maneira instintiva, claro. Muita coisa que eu estudo não tem gravação. Não tenho referência. Muita coisa de música antiga, que a gente descobre hoje, ou descobertas nos últimos anos, não se tem referência. Não tem quem imitar. Graças a Deus! Porque isso foi também um grande problema: um imita o outro e fica sempre o mesmo tipo de execução, não é? A minha maneira de abordar é primeiro conhecer o texto, conhecer a música, aprender tecnicamente.

Depois, depende da situação, às vezes tento construir algum discurso dentro da minha cabeça. Tento falar a música, mesmo. Como se fossem frases, sílabas e palavras. Principalmente na música antiga, tenho muito essa coisa da retórica na música. Tem um ritmo inerente àquela música, que vem, para mim, falado. Ou, às vezes, tento construir uma história, imagens na minha cabeça, que eu não preciso comunicar ao público. Eles não precisam conhecer aquela história que eu faço para mim, mas eu quero ter uma história para mim, para ser eloqüente e inteligível, para eu, talvez, representar coisas com a música. Não ser só notas.

Ter uma representação de um caráter. Como você vai dar um caráter à cada frase? Vai procurar ter, por exemplo, um contraste de caráter. Vai detectar dentro de um tema musical um caráter masculino, digamos, e num outro tema, um caráter feminino. E dar esse caráter, na maneira de tocar.

É muito amplo. Eu tento ser muito expressivo e muito explícito com aquilo que eu quero mostrar com a música e, ao mesmo tempo, muito instintivo. Eu deixo muita coisa para a hora. Montar uma interpretação é uma coisa tão completa! Depende do que você está montando.

Um Concerto de violoncelo e orquestra, você tem que estudar a parte da orquestra, você tem que estudar a música daquele compositor, se familiarizar com o estilo dele, ver qual é o caráter da peça... pela tonalidade, por exemplo. Será que é uma tonalidade que representa alguma coisa? Um Ré menor, digamos, lamentoso. É uma tonalidade trágica? Tem muito esse simbolismo, dentro das tonalidades. E claro, pelos 
temas, pelas linhas melódicas, você pode detectar tal e tal caráter, e montar uma interpretação em cima disso.

Mas, com certeza, o mais grosso, para mim, é a época musical. Se é música do séc. XVIII tem uma estética, um instrumento, um arco específico, uma maneira de tocar que eu já vou por ela, e, lá dentro, vou construir o que vai para aquela peça. Se é música romântica, ou música do séc. XX tem uma maneira de tocar, um instrumento certo, as cordas de metal e não de tripa, enfim, tudo o que vai junto: técnica, estética, história, que é muito sólida para mim, muito clara. Eu separo muito as coisas. Não gosto de misturar.

Eu gosto de tocar Jazz, de tocar música barroca, mas eu não vou ficar misturando as duas coisas. Cada uma tem uma estética, uma técnica muito definida, muito clara. Nesse sentido sou um pouquinho... purista. Ao mesmo tempo, sou muito aberto pra tocar vários tipos de música. Acredito que tem que ter essa flexibilidade, como intérprete. Não tem porque tocar com mesma estética e técnica que você toca Tchaikovsky, usar a mesma para tocar Bach. É absurdo! Não só não tem porquê, mas me parece absurdo, hoje em dia.

Acredito que o músico, o intérprete bom, hoje em dia, é polivalente. Sabe como lidar com esses estilos diferentes, instrumentos diferentes, estéticas e técnicas diferentes.

\section{Qual o diferencial expressivo do violoncelo para você?}

Eu sou suspeito! (risos) Eu adoro o violoncelo! É gigantesco! Eu acho que é um instrumento inacreditável! Primeiro, a tessitura dele é muito grande. Vai de muito grave a muito agudo. Se acrescentar os harmônicos artificiais, é uma extensão gigantesca. Depois, eu acho que essa cor que ele tem, muito quente, próxima à voz humana, é muito expressiva, é uma cor muito bonita, o timbre do instrumento é muito bonito.

Ser um instrumento de cordas, que tem o arco... O arco é uma riqueza inacreditável. O arco é tudo, no instrumento. Dou muito mais atenção na mão direita. É um potencial expressivo extraordinário, porque você pode ter som contínuo, que raramente você tem em outros instrumentos. O piano é percutido, nos sopros você tem que respirar... no violoncelo, nos instrumentos de arco, você pode usar as duas coisas. 
Pode ter o lado percutido, pode ter o lado articulado, e esse lado de legato, do grande som contínuo.

E é um instrumento que tem todo esse potencial de se tocar com a mão, pizzicato, de se fazer vários tipos de música, nesse sentido. Você pode tocar como um contrabaixo, ou com a mão, fazendo acordes, porque, mesmo que seja difícil, a gente tem quatro cordas, e podemos fazer um monte de arpejos e acordes. Pode ser um instrumento que acompanha, como solista. É um potencial gigantesco.

E também é um instrumento que tem um corpo grande, e pode virar quase que uma percussão, ele soa, ele tem madeira, você pode bater nele, fazer sons diferentes. Tem todo esse lado super rico de harmônicos. Você pode criar um som muito quente, muito completo, com o violoncelo, pelas notas, pelas simpatias, pelas vibrações de cordas soltas, você toca notas sensíveis a essas cordas. Você pode criar um som muito envolvente, quente e grande, com o violoncelo.

Também o fato de não ter trastes o diferencia dos instrumentos com trastes. Você tem essa possibilidade extraordinária de tocar todas as notas no meio dos semitons, de ter glissandos, de ter todos os quartos de tons, e outros tipos de subdivisão do tom, que tem na música oriental, nas músicas do mundo, por aí. É um instrumento muito versátil. Você pode tocar muito grave, ou muito agudo, e essa facilidade de tocar todo o tipo de afinação, de subdivisão do tom, de escala, de modo exótico, essa coisa “fretless", é extraordinária.

Não é por acaso, você pode montar uma orquestra de violoncelos e pode ficar muito interessante, um timbre muito completo. Tem o grave, o agudo, todas as possibilidades sonoras. Agora, numa orquestra de... não quero comparar com outro instrumento, pode ficar mais facilmente chato. O violoncelo é muito amplo... nossa! Meu Deus!

Acredito que tem que se fazer esse esforço, no instrumento, hoje, para ampliar as possibilidades dele. Eu sempre procurei isso, achei que tinha um potencial que não estava muito utilizado pelos outros cellistas: essa coisa de tocar Jazz ou tocar música improvisada, obviamente te obriga a explorar possibilidades sonoras inéditas do instrumento. E são ilimitadas. É inacreditável. 


\section{1. 3. Entrevista com o Professor Fábio Presgrave (UNESP).}

(Realizada em $1^{\circ}$ de novembro de 2007).

\section{Qual foi a sua formação no violoncelo?}

Fiz meu Bacharelado na Juilliard, com Harvey Shapiro, que até faleceu recentemente. Foi uma sorte que eu tive. Ele faleceu com 97 anos, imagina que ele começou a tocar com 7. Foram noventa anos de violoncelo. E quando eu falei com ele, dois meses atrás, ele tinha acabado de quebrar o braço e era irreversível. Então, parou de tocar e morreu.

Depois, estudei com o Joel Krosnick, do Quarteto Juilliard, o meu Mestrado. E essa foi a minha formação básica. Alguns Masterclasses que abriram algumas idéias, com gente tipo Bonnie Hampton e Tim Eddy.

\section{Você considera que teve acesso a uma base técnica e teórica suficiente? Se não, o que faltou e como você superou essas carências}

A base técnica, considero que sim, porque tive a sorte de ter um professor que foi muito... não paciente, porque ele não tinha paciência nenhuma (risos), mas que não abria mão de que cada aspecto técnico do violoncelo estivesse bem definido. Mas era uma coisa meio louca, o Krosnick é que organizou as minhas idéias, no geral.

Base teórica, tive a sorte de, na minha época de garoto, ter excelentes professores na Escola de Música da UFRJ. Eram professoras de idade avançada, reminiscentes da era gloriosa da Escola que teve Oscar Borgeth, Iberê Gomes Grosso, Paulo Silva, entre outros. E o resto, a formação na Juilliard foi bem direta, bem específica. É claro que eu sempre pesquisei muito, sempre li muito, sempre corri atrás, sempre gostei de trabalhar com compositores, então essa parte teórica ficou boa, funcionou por causa disso. Porque depois que você trabalha com o compositor, você transpõe os mesmos problemas, os mesmos assuntos, para a música do passado.

\section{Você considera pertencer a uma escola violoncelística? Qual e por quê?}

Mais ou menos. Acho que hoje em dia não tem como se falar de escola de violoncelo. Se você fosse ver nos anos 50 uma orquestra francesa, todos os 
violoncelistas estavam com o espigão baixo, com o braço baixo, você saberia a que escola eles pertenciam, e se você fosse na Rússia, todos eles estavam imitando já o Rostropovich, tocando com o cello deitado. Hoje em dia, o fenômeno da globalização é evidente.

Mas eu acho que teve uma escola a que eu fui exposto, uma escola que eu não sei como definir, escola "novaiorquina" talvez, que foram os grandes cellistas que estiveram lá no ápice de sua atividade na metade do século XX, que foram o Leonard Rose, o Harvey Shapiro,a Zara Nelsova, o Bernard Greenhouse, que geraram uma forma de pensamento muito interessante. Uma escola não baseada em tradições, mas na tentativa de um entendimento mais puro de como funciona o instrumento e como funciona o corpo em relação ao instrumento.

Mas eu não sei se poderia ser classificado como uma escola. Eles eram muito diversos, mesmo do Shapiro para o Krosnick, dois grandes cellistas, dois grandes formadores de violoncelistas, mas a maior coisa em comum do pensamento deles era essa: do cello não se basear em tradição empírica, mas em racionalização, em como fazer, como funciona. Então eu acho que esse é um grande benefício que esses violoncelistas trouxeram.

Não é à toa que a quantidade de gente tocando bem lá é um absurdo. Não é uma escola artesanal, que forma um em cem, mas que se propõe a... de cem, fazer $90 \%$ tocarem bem. Eventualmente, se forem excepcionais vão ser excepcionais com ou sem isso, então é uma escola democrática, até, de não se basear no empirismo.

\section{Você acredita que uma determinada escola seja melhor? Para você, existe o certo e o errado?}

Existe o que funciona e o que não funciona. E quando você passa a ver a coisa que não seja pelo ângulo do empirismo, você analisa isso friamente em você mesmo, mesmo aquela tradição, que você aprendeu do seu grande mestre, não funciona, e é você que vai subir no palco, e é você que tem que dar um jeito de fazer funcionar.

Então, uma escola melhor ou pior, não, não tem.. Até porque, hoje em dia, é difícil você afirmar que ainda haja algum tipo de escola. 


\section{Como você segura seu arco? Por quê?}

Explicar só em palavras é complicado, mas... o que eu tento usar é um alinhamento, que vem das costas, passando pelo ombro, cotovelo, pulso, até chegar na ponta dos dedos, que não tenha formações de ângulos. Ou seja, que o pulso não esteja em uma posição desnivelada, ele deve estar sempre em linha com o cotovelo, que é a posição de postura, no geral, mais saudável. Acho que, o Yo-yo Ma, quando esteve no Brasil, há pouco tempo, definiu bem isso, ele vem também dessa tradição... ele foi aluno do Rose, e definiu que o pulso e o cotovelo têm que estar sempre alinhados. Ou seja, qualquer coisa que extrapole para cá ou para cá, para cima ou para baixo, não é saudável. Então, se ele consegue fazer isso melhor que todo o mundo... então acabaramse as desculpas (risos), de que tem que fazer de tal jeito, não é?

Vejo na mão direita que as juntas, os nervos, e os músculos têm de conseguir reverberar, eles têm que conseguir respirar. Eles têm de estar firmes, mas ao mesmo tempo flexíveis. Uma grande confusão é relaxamento com falta de firmeza, ou tensão com firmeza. São coisas bem diferentes. E, claro, tem a flexibilidade dos dedos, que é uma coisa que vem do Rose, transposta pela escola do Galamian, de violino.

O tal do "collé", também gera muita confusão. O Rose revolucionou um isso, quando gravou o Concerto de Schumann: ninguém sabe que arcadas ele usou. Não tem como saber, porque a conexão é tão perfeita que ele realmente conseguiu enganar o mundo inteiro ali. E isso vem da conexão do "collé", o Galamian, foi um divisor de águas na vida dele.

O Shapiro, que trabalhou junto com ele, sempre me contava que quando o Alexanian chegou em Nova Iorque, o Rose devia ter dezessete, dezoito anos, e ele ouviu o Rose tocando a sonata do Franck, falou: “Aqui está o melhor violoncelista do mundo!”. E aí ele rompeu com o Casals. Você vê, o Casals ficou muito indignado. É claro que era um exagero completo e absoluto, não é? Mesmo novinho ele já era esse absurdo, mas acho que a sistematização do Galamian é que gerou os grandes alunos do Rose, que foram o Yo-yo Ma, o Lynn Harrel, e os violoncelos de orquestra que estão por aí, também.

Ah, e outra coisa que me influenciou, demais, foi uma idéia do Parisot de mover, sempre, de grandes grupos musculares para pequenos. Ou seja, qualquer movimento que haja no pulso ou nos dedos, ainda é um reflexo de um movimento maior do braço, 
com o suporte da coluna. Não há nada, no violoncelo, que sejam "manivelas" ou quebras de direcionamento de energia. De pulso, ou de cotovelo, ou de fraquezas laterais na mão do arco. Não que o pulso seja bloqueado, mas ele faz parte de um movimento maior do braço, que ele nunca lidera.

\section{Qual é a sua maneira de uso da mão esquerda? Por quê?}

Mais uma vez, o alinhamento é igual: não pode ter nada que quebre a fluência de energia de pulso ou de cotovelo. Eu gosto de ter o mesmo ponto de cotovelo na primeira posição e nas posições do polegar, o que não significa que seja um ponto alto, mas eu não gosto de sentir que eu estou afundado, cavado, e aqui ${ }^{45}$ e que depois eu tenha que tensionar o cotovelo para cima... Eu quero conseguir mover. Isso aí é uma coisa do Shapiro, que também é uma idéia que influenciou o Yo-yo Ma, e você vê claramente nele.

Outra coisa é o vibrato que eu faço, que é o vibrato parte do antebraço, usando a flexibilidade dos dedos e não de uma rotação do pulso. Porque, na minha idéia, girar o pulso é uma desafinação, só. Eu não quero sentir que mudo a nota de lugar ${ }^{46 .}$

A idéia do "peso" eu acho ruim, didaticamente, o conceito é bom: a idéia de que o braço inteiro abaixa a corda. Acontece que gera mais problemas e dificuldades do que soluções e a pessoa acaba cavando com a mão, quando a energia que você precisa para tocar é só a da corda encostar no espelho, qualquer coisa a mais é desnecessária, não é saudável. E, outra coisa, você não move. Se você estiver com sua mão cavada, você não move. Você tem que estar tão leve, assim você muda pra qualquer lugar, fácil, os seus dedos articulam rápido. Com firmeza no que eu chamo de "junta do polegar"(estrutura muscular entre o primeiro dedo e o polegar). Os dedos não empurram, mas as juntas estão firmes e os dedos articulam.

Sobre as mudança de posição, aí acho que vale a pena falar das imagens que os professores criam para passar certas coisas, que geram aberrações. Essa é umas das coisas que a gente tem que tomar cuidado, porque, às vezes, uma imagem que para a gente é muito clara e muito simples, vira uma coisa exacerbada. O Starker criou aquele

\footnotetext{
${ }^{45}$ Aqui, provavelmente, ele se refere ao conjunto antebraço-cotovelo.

${ }^{46}$ Nesse ponto, o Prof. Fábio gesticula, deixando a polpa dos dedos exatamente no mesmo lugar e vibrando, movendo somente as juntas, ou, seja, as falanges dos dedos para cima e para baixo, juntamente com a mão, e o antebraço todo, como uma peça só, sem rodar os pulsos, isoladamente.
} 
método de ir com o cotovelo e fazer um movimento circular ${ }^{47}$. Se você assistir o vídeo dele, tocando a Suíte do Casado, não vê isso acontecer nenhuma vez (risos). É uma imagem, é uma sensação interna, é essa noção, muito importante, que durante a mudança, o dedo não está na corda, apertado, ele está por cima da corda, ainda na corda, mas por cima.

É por isso que são péssimos aqueles estudos de mudanças de posição com glissandos de uma nota para a outra, porque só geram uma mudança dura e travada. E outra coisa, a gente cria hábitos. E a pessoa que faz isso no estudo, vai chegar no palco e vai tocar assim. O portamento é uma coisa lindíssima, mas tem que ser de bom gosto, combinando pesos e velocidades do arco, com velocidades específicas da mão esquerda. Então, essa imagem do Starker acabou virando um "animal completamente à parte".

Tem violoncelistas, alunos e ex-alunos dele, que são excelentes, mas que você vê aquilo e é até desconfortável de se observar, e além de antinatural. Esse daqui ${ }^{48}$, tudo bem, porque ainda tem a ação da gravidade, mas esse daqui ${ }^{49}$ é completamente fora de propósito. O Shapiro até dizia que esse movimento, do Starker, dobra o tamanho da mudança. E ele fazia o oposto, se ele estivesse na primeira posição, jogava o cotovelo pra frente e movia só o antebraço, com a maior leveza possível nos dedos. Ele dizia que ele cortava o movimento no meio e realmente era impressionante, quer dizer, ele com 94, 95 anos, movendo, fluindo, mesmo com a mão cheia de artrites, de artroses. A base é mais ou menos essa. E, claro, essa mesma reverberação dos músculos, das juntas e dos nervos da mão direita que a gente teria que funcionar na mão direita.

\section{- Mas então você pensa a mão inclinada ou a quadrada, a quadrada, não é? (pela} observação dos gestos feitos pelo Prof. Presgrave)

Não necessariamente. Eu penso que tocar rápido e tocar lento são duas coisas diferentes, a comparação que eu faço é a de andar e a de correr. Ao andar, você transfere o peso de um pé para o outro, e correr você deixa seu peso estável, e fica leve, passando de um pé para o outro. Então, quando eu toco lento, eu balanceio a minha mão de dedo pra dedo, sem que o cotovelo altere. Eu nunca vou passar com meu cotovelo do nível do meu corpo. Meu corpo é sempre reto, nunca é virado para a direita ou esquerda.

\footnotetext{
${ }^{47}$ Aqui, o Prof. Presgrave gesticula a mudança de posição grave para alguma aguda, na mão esquerda, fazendo um gesto circular com o braço, levantando-o e abaixando-o em seguida, durante a mudança.

${ }^{48}$ Aqui o Prof. Presgrave mostra o movimento de descer o braço.

${ }^{49}$ Mostra o movimento redondo do cotovelo.
} 
Quando eu for tocar passagem rápida, eu balanceio com o último dedo que está tocando, porque o primeiro e o segundo se viram, o terceiro e o quarto, não. Se eles estiverem fora de balanço, não funciona

\section{Qual a importância do polegar da mão esquerda para você? Como você o usa?}

O polegar tem uma função específica na posição do polegar, porque ele é a referência, e não o primeiro dedo. O primeiro dedo deixa de ser referência. Este conceito, na verdade, é uma coisa que vem do Luigi Silva. O Luigi Silva, aliás, se você quiser ver, tem disponível na Biblioteca da Carolina do Norte, um arquivo dele. Ele escreveu volumes e volumes sobre técnica de violoncelo. Ele foi professor do Krosnick e professor do Tim Eddy, do Quarteto Orion.

O Silva tinha a mão extremamente pequena, e, nos anos vinte, quanto ele foi tentar entrar para a classe do Bonucci, em Roma, o mesmo lhe falou que ele tinha a mão que não servia pro cello. Então ele criou um sistema de tocar em que o polegar está sempre em cima do espelho. Ele não conseguiria fazer uma extensão, por exemplo, si ré\#, na primeira posição. Ele teria que tocar polegar - 3. Só que isso gerou para ele uma organização perfeita em oitavas, o tempo todo. Então, se o Silva fosse fazer uma mudança, como no Concerto de Schumann, sol - fá (início da terceira entrada do solo) ele nunca mudaria para o fá com o terceiro dedo, mas para a oitava do fá. Não como uma coisa dura, mas, como um bloco da mão, como um guia.

Mesmo em uma mudança para o segundo dedo, para ele, a orientação dele era sempre a oitava. Com cinqüenta anos, o Rose conheceu o Silva e mudou toda a técnica de mão esquerda dele, por causa disso. Então, se você pegar os dedilhados do Rose, todos desta fase tem o uso do polegar. Ele ficou tão abismado com aquela facilidade do Silva, que mudou tudo. Ele passou a fazer uso do polegar, mas um uso sempre em oitavas.

Bom, e nas posições de baixo, meu polegar sempre acompanha o segundo dedo e nunca tem nenhum tipo de pressão. Ele só tem uma sensação leve do braço. Ele nunca é, assim, um "alicate", e, principalmente, um alicate que faça ele rodar. Então, quando eu vibro, o polegar se move junto com o movimento de braço. Ele não fica estático e roda, não, ele é parte do braço, e redondo sempre. Acho que é o que você vê no livro do Tortelier, mesmo. Esse conceito que você vê no Tortelier é o mesmo conceito que os 
americanos chamam de "junta do polegar", também. Seria assim: o primeiro dedo toca, o primeiro e junta do polegar, o segundo, e junta do polegar, terceiro e junta do polegar, quarto. Eles nunca entram isolados.

\section{Você acredita que devemos ter uma "forma de mão"?}

Não, acho que só atrapalha. É importante você ter uma consciência de posição, mas eu não acredito na forma da mão, porque eu não uso pressão nos dedos anteriores. Quando eu faço uma articulação $1-3^{44}$, no momento em que eu toco o 3 , o 2 e 01 não tem mais pressão. Quando eu toco o quatro, o três, o dois, o um não tem mais pressão. E a forma da mão impede de balancear. Eu acho que é legal, assim, para o primeiro ano de violoncelo, talvez, mas a afinação realmente correta só ocorre quando você consegue balancear bem a sua mão. Principalmente nas posições de polegar, quando você começa a ver extensões desconfortáveis, se você tentar achar uma forma da mão, ela não existe.

\section{Para você os dedos da mão esquerda devem estar sempre abertos em uma posição enquanto tocamos, ou não, esta posição deve ser adaptável e relaxada?}

Não, nunca aberta, de jeito nenhum. Isso daí é uma visão, um conceito que vem do Galamian, que já está bem unificado, em todos os instrumentos, nas escolas mais modernas. O Galamian veio com essa história de que o dedo toca e o outro perde a pressão, outro dedo toca e o outro perde a pressão. E o resultado da modernização das escolas, do Galamian, foi assombroso. Não é à toa que surgiram aí Perlman, Zuckerman, Schlomo Mintz. Acho que todos os violinistas da atualidade, sem exceção, passaram, de alguma forma, pela escola do Galamian. Desde o spalla da Filarmônica de Berlim até o spalla de Nova Iorque, que foi aluno dele, até esses grandes solistas, mas que vem dessa modernização dessa flexibilidade da mão esquerda. $\mathrm{O}$ violino deixou de ter, assim, formas duras, para formas mais flexíveis. E no cello, sem dúvida, mais ainda. Eu vejo escolas mais modernas de contrabaixo, também, fazendo a mesma coisa, e mais ainda para eles, em que as formas são mais abertas, mais desconfortáveis. 


\section{Como é seu estudo diário? Existe uma rotina? Existe uma programação prévia?}

Não, eu já fiz isso, durante minha época de estudante. Eu tinha meus estudos de mecânica, mas eu realmente aprendi a estudar quando eu fui para os Estados Unidos. No meu primeiro ano de violoncelo eu fui proibido de estudar sozinho. Eu ia quinze minutos, diariamente na casa do Shapiro, para estudar com ele, e ele sempre me falava: "Não estuda isso sozinho que você piora". E era verdade.

O estudo é, na verdade, formação de hábitos. E a formação de hábito, se não for consciente, é uma formação de hábito ruim. Eu fazia exercícios mecânicos, aprendi a resolver os meus problemas mecânicos, ou no repertório ou nos estudos, ou nas escalas, e nisso não tinha diferenças, ou nos excertos orquestrais. E, claro, nos sete anos de formação básica, na Juilliard, eu estava relembrando outro dia, se eu fiz sete Concertos foi muito. Mas a forma de tudo é que me deu condição de fazer o que eu precisasse fazer.

Hoje em dia, com o tipo de vida que eu levo, tenho que ser extremamente objetivo, não posso demorar para aprender as coisas. Tem vezes que eu tenho três, quatro dias para me preparar para um concerto, e tem que ser eficiente, tem que ser bem feito. Então eu não posso "viajar" muito, tem que dar um jeito de sair, e tem que sair. E, é claro, quando eu sinto que tem, assim, três semanas que eu vou ficar só dando aulas, aí sim, eu dou uma apertada no ritmo de estudos, aprendo alguma coisa nova, mas, esse estudo diário de quatro ou cinco horas, você só tem o luxo de fazer durante a sua época de Universidade, mesmo.

Mas eu tento ser o mais objetivo possível, e tento não me fixar mesmo no que eu já sei. Tanto que nas minhas partituras, nenhuma tem dedilhado, nenhuma tem arcadas. Eu até posso tirar uma cópia e copiar o que eu fazia em alguma época, mas eu não quero me impedir de ter uma idéia melhor. Mais uma vez, eu não quero me basear no empirismo. O teu corpo se transforma de dia pra dia, a sua facilidade se transforma, as idéias musicais se transformam. Então eu tento sempre reagir o máximo possível a isso, e explorar, e não tenho medo de errar, não tenho medo de tomar riscos, porque são exatamente nesses riscos e nesses erros que você constrói coisas sólidas. 


\section{Para você, o que é mais importante a se buscar e pensar, no estudo diário?}

Acho que é exatamente isso que eu falei: o reflexo. Condicionar o corpo de uma forma positiva, e sempre condicionar o reflexo de uma forma boa. Seria isso.

\section{Você faz tudo o que seus mestres pregavam? Algo foi adaptado? O quê? Por qual razão?}

Não, eu não faço. Aliás, uma das coisas que eu mais gosto é que eu consegui, depois que eu saí dos Estados Unidos, desenvolver uma linguagem minha. E é claro que a base do pensamento, a forma do pensamento, sim, é muito parecida. Mas eu até fiz uma experiência interessante. Quando eu acabei o meu Mestrado, na Juilliard, ia continuar lá, eu ia fazer meu Doutorado lá. Eu ia continuar estudando com o Krosnick, que foi meu grande mestre, no final.

Ele tinha uma classe, puxa, nossa classe era maravilhosa. A gente tocava... tinha um negócio que se chamava Studio Class, em que toda semana você tocava para o grupo. Agora você imagina, tinha a Alissa Weilerstein, uma violoncelista que solou com a Filarmônica de Berlim, é uma das maiores cellistas do momento..., tinha o Mark Kosower, um cara que jovem já havia sido assistente do Starker, com vinte e dois já estava ficando careca de tanto ter estudado cello, na vida (risos). Ele foi premiado no Concurso Rostropovich.

Tinha vários ganhadores de concurso internacional, vários que, hoje em dia, estão fazendo primeiro cello por aí, e é claro que eu queria continuar nesse ambiente, mas, na época, recebi um convite para o Rio, estava com saudades do Rio, do país. E passei um ano no Rio, em que eu saí ali, do "olho do furacão", e pude dar uma respirada.

E comecei a fazer coisas diferentes, e comecei a fazer as coisas do meu jeito. E para minha surpresa, quando eu voltei, um ano depois, e fui tocar para o Krosnick, ele falou: "Olha, eu estou feliz por você, porque se você tivesse ficado em Nova Iorque, esse ano, você não teria progredido tanto". Então, é claro que eu uso a forma de pensamento, mas eu quero ver o que funciona mesmo, porque quem sobe para tocar sou eu, não são eles, e mesmo com os alunos, eu uso a forma de ensino deles, mas a realidade no Brasil é outra, o tempo de estudo é outro, a idade em que as pessoas 
começam é outra. Às vezes, o ensino inicial não é tão maravilhoso como é lá fora, em que as pessoas, com quinze anos, já têm a técnica bem estruturada, não é.

Aqui, muitas vezes, é no período de Universidade que eles vão começar a querer estruturar a forma de tocar. Então tudo isso é readaptado. E muda muito! E com cada aluno muda, com cada concerto muda e com cada situação muda. E isso, na verdade, é a parte mais interessante, isso que não deixa você ficar entediado (risos).

\section{Você se preocupa em testar novas idéias divergentes das suas?}

O tempo todo. Eu mudei já, acho que quatro ou cinco vezes, drasticamente, minha forma de tocar. Então, quem me visse há quatro, ou cinco anos atrás e me visse hoje em dia, ia falar assim: "Ô, mas você ensinava exatamente o contrário! E tocava..." É, mas... E se alguém, hoje, me convencer e se eu achar interessantíssimo, melhor do que eu faço, e se eu sentir bem no meu corpo, eu mudo, sem problema nenhum.

\section{Você se preocupa com tensões no corpo? Sente alguma? Elas atrapalham ou atrapalharam de alguma maneira a sua execução? Faz ou fez efetivamente algo para melhorá-las?}

Acho que a preocupação com a tensão no corpo ocupa $70 \%$ do meu tempo, pensando no cello. Eu já estou plenamente convencido de que elas é que nos impedem de realizar, ou não, uma boa execução. Tudo de ruim que você possa pensar, eu já passei. Eu tive um problema, aos dezesseis anos, chamado "síndrome do impacto", que são desgastes da cartilagem do ombro, porque eu usava a técnica de chegar baixo talão, com o pulso alto, e alto no talão ${ }^{45}$, como pulso quebrado. Então, a "síndrome do impacto" é uma coisa que tem muito, você tem, com esse movimento aqui (o mesmo movimento repetitivo que um tenista faz).

A minha sorte é que eu era novo, consegui regenerar, e o médico, na época, falou: "Bom, você tem que achar uma posição estável, para seu cotovelo, em que ele não altere tanto aqui, senão, nisso daí você vai ficar impossibilitado".

Quando fui estudar com o Shapiro, foi a primeira coisa que ele me falou. O pulso, o ângulo do cotovelo é igual, na maior parte do tempo, na mão direita e na mão esquerda. Sem essa "bateção de asas"! (risos) Foi essa a terminologia que ele usou. Depois que eu usei isso, resolveu. 
Quando comecei a tocar em público, muito, eu sentia tensões na mão esquerda que me impediam de mudar bem de posição e de vibrar relaxadamente, e eu descobri essa tensão do polegar e é por isso que eu evito qualquer alicate com o polegar; descobri que o vibrato de juntas funciona muito melhor que o vibrato rodado, essas são dificuldades que você passa.

E um dos maiores exemplos que eu tenho é o Shapiro, que, com noventa anos de idade, ligava para mim e dizia: "Olha, eu descobri um jeito melhor de usar o polegar." (risos) E pior é que ele vibrava melhor com o polegar do que com os outros dedos, quando ele mostrava. Ou o Starker, que disse que a cada minuto da vida dele ele descobre formas mais e mais soltas e relaxadas de se tocar.

Acho que é uma descoberta eterna, até porque seu corpo muda, sua cabeça muda. Tem coisas que, com trinta, você vai tocar e você pensa. "Puxa, mas com treze eu fazia isso sem problema nenhum!” (risos) E, ao contrário, tem coisas que você não fazia nem em sonho e que você faz com facilidade.

Então, você sempre se adapta às situações, mas a escola que eu tento passar para os alunos é a mais saudável possível. Depois cada um faz o que quer, mas eu tento fazer que eles toquem baseados no bom senso. O que seria, assim, perguntar para um médico: "Se eu fizer isso todos os dias da minha vida, por seis horas, vai funcionar ou não vai?"

\section{O que você acha sobre a idade em que alguém deve iniciar seus estudos de} violoncelo? $O$ que você acha da realidade brasileira em relação a esse assunto?

É claro que seria ótimo se todo mundo começasse com sete, oito anos, com um ensino saudável, com um instrumento bom, e com um acompanhamento dos pais, em casa, mas tem um caso excepcional, que é o do Carter Brey, que é um dos maiores violoncelistas do mundo, ganhou o Prêmio Rostropovich, e é o primeiro violoncelo da Filarmônica de Nova Iorque, que é o emprego mais cobiçado do mundo, e é o que paga mais... e começou com dezessete. Então, acho que o que interessa mais é a cabeça, porque ele começou com dezessete, e com vinte anos ele já estava com nível de Conservatório de primeiro nível, e, com vinte e dois, vinte e três, ganhou o prêmio Rostropovich... Competindo com gente que começou a estudar com cinco, seis.

Então, eu não acho isso determinante, mas eu acho, conheci um pouco dele, na época ele deu aula lá, e é extremamente rápido e objetivo. Se funciona, faz, se não 
funciona, não faz, acabou. E muito, extremamente intelectual com os assuntos do cello. Então eu acho que o legal seria poder começar cedo, mas não é determinante. Eu também não comecei tão cedo assim, eu comecei com treze. E eu acho que a realidade no Brasil, em que as pessoas começam, é mais ou menos essa, entre dez e treze, mas, seria isso, acho que não é determinante, não.

\section{Quais as maiores carências dos alunos brasileiros, em sua opinião?}

Primeiro, uma falta de um ensino, não vou dizer sistemático, mas um ensino que ensine os bons hábitos de se tocar o instrumento. No Brasil você ainda tem uma gama de conceitos atrasados que precisa ser atualizado. As escolas todas já se unificaram, não tem mais esse negócio de Escola Francesa, Escola Russa, Escola Americana, e isso daí que eu tenho reparado, e tenho tido uma sorte, lá no instituto Baccarelli, porque tem vindo grandes professores do mundo inteiro. Esse ano aqui teve o Yo-yo Ma, o Greensmith, do Quarteto de Tókio, e teve o Alexander Hülshoff, do Trio de Bamberg, e o que eu tenho reparado...

E no passado veio o Christian Poltéra, que é um cellista maravilhoso, da minha geração, ele é o protegido do Schiff. O que eu tenho reparado é que o ensino deles é igual. Eles tratam dos mesmos assuntos de relaxamento, de flexibilidade, de controle de velocidade do arco, e isso daqui é um grande mal entendido no Brasil, esse negócio de sempre tocar do talão até a ponta, e o arco não tem nenhum tipo de controle de velocidade.

Mesmo esse conceito de forma, de tensão no polegar, de apertar o polegar, de tensão excessiva de primeiro dedo no arco, eu acho que ainda tem muita coisa baseada em um empirismo que esse algum ouviu falar isso em algum lugar, não é uma coisa sistemática. No Brasil, na verdade, estamos tendo uma grande vantagem que, em São Paulo, está tendo um movimento musical muito forte, do ensino de fora. E que, se fosse mais bem observado, já ia quebrar várias dessas tradições, que na verdade não ajudam, só atrapalham.

A esse ensino saudável, poucas pessoas têm acesso. Se você pensar, quantos estudam violoncelo, só em São Paulo, quantos têm acesso a uma formação, assim, que se baseie realmente em coisas mais modernas. 
Quando começou a profissionalização da música, no Brasil, em grande parte foi devido à formação das orquestras. E, visualmente, numa orquestra, todo mundo arremessando o arco, parece que está saindo som, mas... não está. Basta observar com cuidado um vídeo da Filarmônica de Viena, da Filarmônica de Berlim, e ver como a velocidade de arco é tratada com um cuidado absurdo, e não como um arremesso descontrolado.

São certos conceitos que atrapalham muito, então, quando eu vejo as pessoas começando a ter um ensinamento, um ensino mais sistemático dessas coisas, o progresso é rápido, e começa a funcionar. "Então o cello não é, assim, uma coisa sobrenatural?" Não. A gente tem que aprender como fazer. Como o Greenhouse fala, até os trinta anos, a gente é como um marceneiro, que aprende primeiro a fazer a cadeira, depois você vai se basear, também, mais em aspectos artísticos. Mas é a aprender mesmo como funciona esse negócio.

E também, acho que na Região Nordeste, Norte, onde estão, talvez, as maiores quantidades de talento puro, se você pegar pela extensão dos lugares, o número de professores é ridículo. Então não falo nem de professores que tenham uma grande formação, nada, de professores, sobretudo. Acaba que Rio e São Paulo viram as únicas possibilidades, e coisas isoladas em outros pontos do país.

Isso tinha que ser mais democratizado e espero que essa nova geração, que eu acho que, eu vejo assim, o pessoal que está com quinze a dezoito, está muito boa, mas eu estou vendo uma geração mais nova, entre dez a doze, de gente absolutamente talentosa e dedicada, e isso é o espantoso. Então, eu espero que essa geração venha a romper tudo isso e modernize mesmo o Brasil, num bom sentido, e transforme o cello numa coisa normal e boa de se fazer, fácil. Não em uma coisa complicada, de outro planeta.

\section{O que poderia ser feito para melhorar a realidade brasileira?}

Seria isso e investimento na camada mais pobre da população, com certeza, porque esse, quando ele tem oportunidade de estudar, esse aluno do Baccarelli, eles vão com todas as forças, porque é a chance da vida deles. E a música, acho, é a maior unidade de transformação, porque ela é apaixonante. Imagina se tivesse... 
Eu fico muito feliz com esses caras que vem de fora e se emocionam com meninos que moram aqui, no meio de Heliópolis, tocando. Tocando realmente em alto nível. Agora você imagina se tivesse condições de fazer isso em Belém, em Manaus, em Natal, em João Pessoa, e nem se fala no interior desses estados! Então, isso daí seria... Então, talvez, as pessoas... eu até incentivo, nas aulas, os universitários a pensarem não só na opção de tocar em Orquestra, que é uma coisa maravilhosa, mas também em dar aulas, também em tocar música contemporânea, também a tocar música popular.

Engraçado que o Yo-yo Ma, quando veio ao Brasil, e perguntaram a ele numa entrevista: "Qual o músico brasileiro que te atrai?" "Jacques Morelembaum”.

\section{Você acha que a musicalidade só se evidencia após o aprendizado sólido de} bases técnicas e teóricas?

Não, não, porque a prova disso são as crianças. Tem criança que não faz idéia do que está fazendo e toca extremamente bem. É claro que amplifica, a técnica amplifica suas possibilidades musicais. Mas não se evidencia assim, não. Claro que, às vezes, a técnica é tão travada que cobre completamente. Eu já vi casos de achar que não sairia nada! Mas que, com trabalho paciente, e com a pessoa entendendo como funciona o violoncelo, você começa a ver: “Ah, tá, tem alguma coisa saindo daí”. Tem alguma coisa saindo, até que chega um ponto em que flui, a música começa a fluir.

\section{Como você constrói a interpretação de uma obra musical?}

$\mathrm{Eu}$, particularmente, estudo muito. Não por estudar, mas porque eu amo a música profundamente, então sempre procuro estudar a música de uma forma global, não quero conhecer só o repertório de cello. Eu estudei profundamente, por exemplo, as Sonatas de Beethoven para piano, o pouquinho que eu consigo tocar, mas, para conhecer. Conhecer Sinfonias, a Música Contemporânea, o repertório de outros instrumentos...

A partir disso, eu tento primeiro jogar com as minhas reações. Eu tento não botar a música numa caixinha, preparada, para depois começar a ter liberdade. Primeiro eu "bombo" a música algumas vezes e aí eu começo a pensar, porque é muito legal o estudo teórico, e eu sou o primeiro a defender isso; mas, se a gente pensar bem, na época de Bach não tinha número romano, não tinha algarismo romano, isso foi 
posterior, na época de Mozart não tinha a Forma Sonata, de Beethoven também não, isso foi uma criação posterior, então isso tudo são formas de observar a música, que, às vezes, a forma não descreve o conteúdo, em si. Não é? Tem aquele livro A Forma Sonata, do Charles Rosen, em que, basicamente, a conclusão a que ele chega, no final do livro, é que a Forma Sonata não existe. Depois de escrever durante trezentas páginas!

Minha dedução é isso: primeiro que não se distingue de técnica, porque a sua atitude física faz você tocar a passagem de um jeito ou de outro. Mas, com certeza, eu não tento botar, assim, no quadradinho certo. Eu já fiz durante um tempo, agora não faço mais. Vou ver minha afinação, vou ver meu ritmo, e depois vou tentar jogar minha interpretação. E a interpretação vem do conhecimento, também. Não é só aquele "santo que baixa", na hora (risos).

\section{Qual o diferencial expressivo do violoncelo para você?}

Eu acho que é, primeiro, o que me fascina, em minha opinião atual, que o grande repertório para o violoncelo foi feito de 1950 para cá. A possibilidade expressiva, o diferencial expressivo é a variedade, a variedade de timbres, a variedade de extensão, mesmo, a variedade de coisas que você pode fazer. Tem alguma coisa na versatilidade do timbre e mesmo nas possibilidades sonoras puras.

Você, por exemplo, ouve uma peça do tipo "Nomos Alpha", "Kottos", do Xenakis, que transforma o violoncelo noutra coisa completamente diferente, e você já pega uma peça mais ou menos da mesma época, que é o Concerto do Dutilleux, que é completamente diferente. O violoncelo já tem outra função expressiva, outra...

Me fascina muito esse repertório de 1950 para cá. Não que eu não ame o Concerto de Schumann, as Suítes do Bach, as Sonatas de Beethoven. Adoro profundamente, mas o repertório atual está sendo muito bom, cada vez melhor, e o que a gente vê nas Universidades é que a pessoa pode se formar sem nem ter lido nenhuma peça atual. 


\section{2. Cruzamento de dados e observações entre as entrevistas realizadas e os Capítulos anteriores}

Os comentários que serão apresentados a seguir foram elaborados com base nas reflexões sobre as entrevistas acima realizadas, bem como no cruzamento de dados com as afirmações feitas pelos violoncelistas pesquisados no Primeiro Capítulo. Esta pesquisadora alerta que tais comentários passam, invariavelmente, pela lente da pesquisadora, podendo vir, eventualmente, de encontro tanto ao que os entrevistadores quiseram realmente expressar, quanto de encontro ao que um leitor pode vir a concluir da leitura das entrevistas. Contudo, as observações abaixo foram feitas com o máximo de cuidado possível e esta pesquisadora se desculpa, aqui, se os comentários não corresponderem totalmente às idéias apresentadas anteriormente.

Tomou-se cuidado, também, de não haver qualquer posicionamento favorável ou desfavorável a uma entrevista ou a outra, pois esta pesquisadora crê que todas as idéias apresentadas são válidas para reflexões sobre o violoncelo, sua técnica e sua prática. Todos os pontos de vista são importantes, além de extremamente bem embasados na formação e experiência pessoal desses Professores. As três entrevistas são, dessa forma, verdadeiras aulas e trazem opiniões de profissionais de grande importância no cenário musical de São Paulo (e do Brasil), e de grandes personalidades individuais.

A maneira, também, de responder às questões é absolutamente indiferente, pois o que realmente tem importância é o seu conteúdo, que se mostra rico de idéias, questionamentos e opiniões pessoais.

É necessário acrescentar, ainda, que os três Professores entrevistados leram as suas respectivas entrevistas, após a transcrição e/ou revisão, e aprovaram a sua publicação tal como estão neste trabalho, previamente.

Os Professores entrevistados, Robert Suetholz, Dimos Goudaroulis e Fábio Presgrave, são pessoas muito diferentes, em termos de personalidade (quem os conhece pessoalmente tem uma clara noção dessa grande diferença), de maneiras de pensar, de maneiras de tocar, de tipo de som produzido no violoncelo, de repertórios principalmente executados, e trabalham em projetos profissionais, também, muitas vezes distintos. 
Além disso, têm diferentes nacionalidades, com distintas formações musicais, bem como personalidades musicais totalmente diversas. Até mesmo a forma como responderam às questões revela, delicadamente, não só um pouco da maneira como pensam, mas também como gostam de falar e de explicar, por exemplo, um mais objetivo e direto, outro mais prolixo e detalhista. E nisso, é necessário concordar plenamente com o Professor Goudaroulis, que disse em sua entrevista: "A diversificação é que dá pimenta, interesse na nossa vida, não é?" E, nessas entrevistas, é realmente marcante como essas diferenças de personalidade podem gerar importantes reflexões sobre diferentes aspectos do estudo, do ensino e do processo de aprendizagem do instrumento.

É interessante notar que, mesmo dentro dessas grandes diferenças individuais, na maior parte das idéias expostas, e nas questões perguntadas, os três Professores têm muitas visões semelhantes, e muitos dos problemas levantados por eles são preocupações comuns a todos. 


\section{2. 1. Pontos de concordância entre os entrevistados}

\section{Sobre a mão direita}

Todos acreditam que a mão direita deve estar confortável, em uma posição relaxada (apesar de divergirem um pouco sobre seu uso, o posicionamento dos dedos e posicionamento do pulso e cotovelos, cada um com sua formação e com as influências das escolas aprendidas em sua trajetória violoncelística, o que será descrito no próximo item), concordando com a maioria dos autores abordados no Primeiro Capítulo: Sazer, Mantel, Pleeth e Rostropovich.

\section{Sobre a mão esquerda}

a) Os três Professores concordam que a mão esquerda deve estar sempre relaxada e confortável, como a direita, assim como pensam como Sazer, Mantel, Pleeth, Rostropovich.

b) Concordam que os dedos podem ficar próximos às notas que serão tocadas, mas que não devem, ou, não precisam ficar exatamente em cima das notas a serem tocadas, prontos para tocar, pois isso geraria uma tensão excessiva, assim como o pensam Sazer, Mantel e Pleeth (principalmente ao tocar notas rápidas).

c) Concordam, pelas suas descrições, que não deve haver pressão dos dedos na corda, além da necessária para abaixá-la, assim como dizem Sazer, Mantel e Pleeth.

d) Todos acreditam que a mão esquerda deve ser adaptável e relaxada e não acham que ela deve estar aberta o tempo todo, pronta para tocar, como dizem Sazer, Pleeth e Mantel e Rostropovich.

e) Esta pesquisadora entende (pelas explicações dos professores e pela observação de suas execuções) que todos esses docentes usam, na maior parte do tempo, a posição definida nos Primeiros Capítulos como "posição quadrada" da mão esquerda, embora façam exceções em casos necessários, tais como em extensões, para determinadas situações de vibrato, e outras, assim como concordam Sazer, Tortelier e Rostropovich (este último apenas pela observação de suas execuções, pois sobre isso não falou, durante as aulas dadas). 


\section{Sobre o polegar da mão esquerda}

a) Todos abordam a importância do relaxamento do polegar da mão esquerda, como Sazer e Pleeth.

b) Falam, também, da importância do polegar da mão esquerda (quando posicionado atrás do espelho, nas posições mais graves) acompanhar o segundo dedo nas extensões, como defende Paul Tortelier.

c) Tratam da importância deste mesmo polegar acompanhar os dedos que estão vibrando, como falam Sazer, Tortelier e Mantel.

\section{Sobre as escolas de mão esquerda e direita}

a) Os três professores falam, cada um a seu modo, de uma idéia de unificação das escolas, idéia não abordada pelos violoncelistas pesquisados no Primeiro Capítulo.

b) Tratam da busca de escolhas entre os aspectos positivos de cada escola.

c) Todos usam o que realmente acreditam que funciona de cada escola.

d) Nenhum deles se sente pertencer totalmente a uma escola específica.

e) Os três demonstram que acreditam que nenhuma escola é inteiramente boa ou ruim.

f) Acreditam que o certo é o que não machuca o corpo, o mais confortável, o mais relaxado, e o que produz maiores resultados, com menor esforço, ou menor tensão, assim como defendem Sazer, Mantel, Pleeth e Rostropovich.

\section{Sobre o estudo individual}

a) Tratam da importância de se estar aberto a experimentar novas idéias, divergentes das suas, o que não foi abordado pelos violoncelistas pesquisados no Primeiro Capítulo.

b) Todos tratam, de alguma forma, da importância do estudo, da pesquisa, de ouvir obras, da leitura sobre música, assim como afirmam todos os autores tratados anteriormente.

c) Dão grande importância aos ensinamentos de seus mestres.

d) Dão importância à busca individual, baseada no aprendizado com os professores, mas que, muitas vezes se opõe a esse mesmo aprendizado, ou seja, a busca de uma identidade pessoal, idéia abordada no Primeiro Capítulo apenas por Sazer. 
e) Abordam a importância de uma base teórica e técnica bem fundamentada, e que esteja sempre em evolução, idéia defendida por todos os autores tratados no Primeiro Capítulo.

f) Falam da importância de um conhecimento abrangente para a interpretação de uma obra musical, como abordam Rostropovich e Pleeth.

g) Nenhum deles tem uma rotina de estudos prévia e pré-determinada, devido às situações profissionais e à grande quantidade de atividades musicais em que estão envolvidos (idéia não mencionada no Primeiro Capítulo).

h) Todos estudam o máximo de tempo possível, como aborda, principalmente, Rostropovich, apesar de ser idéia aparentemente exposta "nas entrelinhas" também por Mantel e Pleeth.

\section{Sobre o relaxamento do corpo}

a) Todos eles têm ou tiveram problemas relacionados a excesso de tensão no corpo, em sua trajetória como estudantes e profissionais (idéia não mencionada no Primeiro Capítulo).

b) Todos eles acreditam que se deve sempre buscar o máximo de relaxamento corporal possível, a fim de obter bons resultados musicais e técnicos, assim como prega, principalmente Sazer, Pleeth e Rostropovich.

c) Todos eles acreditam que se deve buscar apoio auxiliar para atingir um maior relaxamento e percepção corporal, que vai, segundo eles, desde a consciência individual do corpo, resultante do estudo e observação, até a busca de ginástica, alongamentos, musculação, consultas médicas, Ioga, tai-chi-chuan, meditação, técnica de Alexander, e/ou qualquer técnica corporal que auxilie essa percepção corporal, idéia semelhante à de Victor Sazer.

\section{Sobre a idade em que se deve iniciar os estudos de violoncelo}

a) Todos acreditam que é melhor iniciar os estudos quando crianças, o mais cedo possível (assim como tratam Pleeth e Rostropovich).

b) A idade preferencial para o início dos estudos gira em torno de seis a onze anos de idade (idéia não mencionada pelos autores anteriores). 
c) Todos concordam que embora seja muito mais difícil e trabalhoso iniciar mais tarde os estudos de um instrumento, isso não exclui as possibilidades de aprendizado, nem mesmo de profissionalização (assim como aborda, principalmente, Rostropovich).

8. Sobre a realidade brasileira (Idéias não tratadas pelos violoncelistas anteriormente pesquisados)

a) Todos concordam que a realidade brasileira é muito carente em tradição, em estrutura, em infra-estrutura, em formação dos professores, carente em investimentos em educação de todos os tipos (inclusive e, principalmente, em formação musical básica).

$\beta$ ) Todos concordam que existem projetos pontuais importantes que têm lutado contra essas carências (todos citaram o projeto Baccarelli como uma dessas iniciativas importantes).

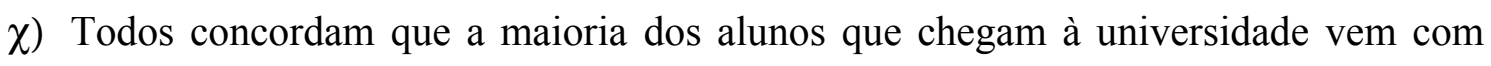
uma bagagem de estudos e de conhecimento absolutamente precária.

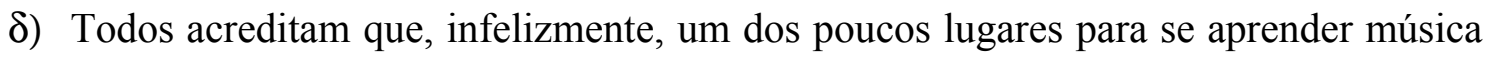
com seriedade, no Brasil, ainda é a universidade.

$\varepsilon)$ Todos gostariam muito que essa realidade fosse completamente diferente, mas não vêem grandes mudanças em curto prazo.

$\phi)$ Todos, ao que parece, acreditam que os esforços isolados e/ou individuais e as novas gerações podem vir a mudar para melhor a realidade do país, em longo prazo.

\section{Sobre a interpretação}

Nenhum deles acredita que a musicalidade só se evidencia unicamente após o aprendizado sólido de bases técnicas, embora acreditem que esse aprendizado sólido proporcione uma fluência muito maior desta musicalidade, bem como o maior desenvolvimento desta. Esta idéia é também tratada, principalmente, por Pleeth, Rostropovich e Mantel, não mencionada por Sazer, e Tortelier acredita que a musicalidade se evidencia somente após o aprendizado sólido de bases técnicas. 
10. Sobre o diferencial expressivo do violoncelo (Idéias não mencionadas no Primeiro Capítulo)

a) Todos eles citaram a grande extensão (tessitura) do violoncelo.

b) Todos citaram a imensa quantidade de timbres e sons que se pode obter do instrumento. 


\section{2. 2. Pontos de divergência entre os entrevistados}

\section{Relativos à mão direita}

Em relação ao posicionamento da mão direita, houve algumas divergências apresentadas.

Por fazer uso dos arcos barroco, clássico e moderno, o Prof. Dimos apresentou formas diferentes de segurar o arco, devido à maneira que era usado o arco nesses períodos antigos da música. Já no arco moderno, afirmou fazer uso, na maior parte das vezes, da chamada Escola Francesa, ou Escola franco-belga (que, conforme vimos anteriormente, também é apresentada como escola italiana, pelos italianos), pois ele diz ter recebido forte influência de seus professores, e diz acreditar, pessoalmente, que essa escola é superior em muitos aspectos. No entanto, afirma usar o arco mais pesado, mais "na corda", típico da escola russa ou do Leste Europeu, como se quiser denominar, quando necessário sonoramente.

Já o Prof. Suetholz, bem como o Prof. Presgrave, usam, ao que parece a esta pesquisadora, uma mescla das duas escolas (pelo que explicaram e pela observação de suas maneiras de tocar) que consiste no posicionamento de dedos típico da escola franco-belga, exatamente como foi explicado por Paul Tortelier, em seu livro, comentado no Primeiro Capítulo, associado a um maior peso, mais típico da escola russa, com o pulso nem tão alto (e leve) quanto o da escola franco-belga, nem tão baixo (e pesado, com menor mobilidade) quanto o pulso utilizado pela escola russa. Trata-se, talvez, de um meio termo.

O Prof. Suetholz também afirma que muda de uma maneira para a outra, conforme a necessidade de mais peso, e, talvez, justamente esse posicionamento intermediário favoreça essa mudança ocasional.

\section{Relativos à formação básica}

Quanto a esse assunto, esta pesquisadora vê uma discordância apenas aparente no que, com uma observação mais abrangente das respostas dadas, resulta, na verdade, em uma concordância, analisada, contudo, com base em pontos de observação diferentes. Cada professor interpretou a pergunta de forma diversa, e então respondeu de maneira também diversa. 
Apesar de o Prof. Suetholz ter respondido que teve, sim, uma formação básica técnica e teórica suficiente, e o Prof. Presgrave ter respondido que foi suficiente em termos, e o Prof. Goudaroulis ter respondido que não, e que nunca é suficiente, essa aparente discordância traz embutida uma concordância, vista de pontos de vista apresentados.

Claro que se tratando em base técnica inicial e teórica, todos devem estar de acordo que receberam uma primeira base suficiente, dada, principalmente a formação acadêmica que lhes foi dada, exposta por eles. Porém, pela leitura subjetiva das respostas apresentadas, pode-se ver, nas entrelinhas, que os três Professores se aperfeiçoaram grandemente em sua prática como músicos profissionais (solistas, ou cameristas, ou músicos de orquestra), com sua experiência como professores, como alunos de diversos professores, bem como pesquisadores que são, do seu instrumento e de sua arte.

E também é claro que, tendo em vista o contexto total de suas entrevistas, todos concordam que nunca é suficiente o estudo e a pesquisa, nem a prática, e que o instrumentista deve estar sempre se aperfeiçoando, crescendo, aberto, conforme declararam, a qualquer idéia nova. 


\section{2. 3. Idéias marcantes, apresentadas apenas por um dos Professores entrevistados}

\section{Professor Robert Suetholz:}

Como idéias marcantes, abordadas somente pelo Prof. Suetholz, temos o conceito muito pertinente do estudo que busque aquecimento do corpo em relação aos movimentos necessários para se tocar o instrumento, feito diariamente e, subentende-se também, antes de uma performance, por exemplo. Essa idéia é trazida como uma busca por estar confortável e à vontade com o instrumento, que ele deixe de ser um "objeto estranho".

Essa sensação de "objeto estranho" é conhecida por qualquer estudante e profissional do violoncelo, pois ocorre diariamente, às vezes mais de uma vez por dia, e varia de intensidade de dia para dia, e de hora para hora, dependendo de uma série de razões, e gera um desconforto inicial que pode, até mesmo, desestimular a continuidade da prática naquele momento, ou gerar uma sensação de que a prática é um sofrimento, idéia combatida por Pleeth, por Sazer e por outros autores tratados nos dois primeiros capítulos.

Esse aquecimento, esse "re-conhecimento" diário do instrumento, acima tratado, é de enorme utilidade e pode resolver inúmeros problemas, desde o desestímulo citado, uma performance menos "presa" e, por isso, mais concentrada e criativa, até o combate de tensões e lesões, entre outros.

Outra idéia bastante valiosa exposta pelo Prof. Suetholz foi a de que cada escola de técnica dá maior importância para resolver determinado problema, ao que esta pesquisadora acrescenta, seja o problema de peso de arco, seja de flexibilidade de arco, seja afinação, seja conforto da mão esquerda, seja vibrato, ou outros. Suetholz acredita que cada técnica diferente dá importância mais para uma coisa ou outra e, com isso, ele acredita que tudo o que fazemos é escolher, e que estas escolhas acarretam um benefício de um aspecto, em detrimento de outro aspecto. Ou seja, o intérprete também escolhe o que vai priorizar quando escolhe as escolas que usará.

Somente o Prof. Suetholz apontou, também, a maneira de se sentar ao instrumento, não tão atrás do violoncelo, mas com ele mais para o lado esquerdo, o corpo aparecendo mais do lado direito, idéia que já foi explicada no Primeiro Capítulo 
por Sazer, e que já era, como vimos, usada por Duport. Essa idéia ajuda, como já foi defendido por Sazer, a um maior alcance do braço direito e do arco nas cordas lá e dó, sem que haja uma constante rotação do corpo para alcançá-las e sem que se tenha que “esticar” excessivamente o braço e a mão para alcançá-las, em posições mais extremas.

\section{Professor Dimos Goudaroulis:}

Uma das idéias pertinentes abordadas somente pelo Prof. Goudaroulis se refere aos diferentes usos do arco e à interpretação voltados ao estilo musical e à época interpretada. O professor propõe que usemos todo o conhecimento musical que se tem, hoje em dia, de como a música era interpretada na época em que foi escrita, e aplicá-lo como uma "fórmula" pré-estabelecida de certos padrões que são necessários para interpretá-la da maneira mais fiel possível aos padrões do período, do lugar e do estilo e, dentro desses padrões, colocar as idéias pessoais, a interpretação do músico.

Outra importante idéia tratada é a da importância da prática profissional para a formação do músico. Ele alega que muito do que aprendeu e do que faz hoje também é mérito de uma intensa vida profissional (como violoncelista solista, como professor, como camerista, como violoncelista popular, como improvisador, como jazzista), da experiência profissional que foi ensinando a prática e foi, também, colocando ensinamentos à prova, o que ele descreve como "aprender tocando e comendo o palco".

Em relação às escolhas de escolas, se o Prof. Suetholz lembrou que a escolha por certos aspectos de uma escola determina a escolha de certas prioridades e que cada escolha ajuda algum aspecto em detrimento de outro. O Prof. Goudaroulis lembra também uma importante decorrência da escolha: elas trazem embutidas em si, aspectos estéticos. Cada escola tem sua estética, de quantidade de som, de tipos de som, de timbres, de maneiras de uso do arco e das articulações, de tipos de vibrato mais ou menos favorecidos, ou seja, uma infinidade de aspectos sonoros que também devem ser levados em conta na escolha de formas de se tocar. Ele afirma: "Eu gosto de tocar Jazz, de tocar música barroca, mas eu não vou ficar misturando as duas coisas. Cada uma tem uma estética, uma técnica muito definida, muito clara para mim.”

Como ele aconselha:

“(...) juntar e usar as coisas boas de cada uma das técnicas, nas estéticas... porque cada escola tem uma estética também. Não é só técnica. Cuidado! É uma maneira de você pensar na música. É uma maneira de você executar, vibrato, non vibrato, enfim, milhões de coisas que vem aí, do lado estético, não é?" 
E esta pesquisadora acrescenta, ainda, que além desses aspectos lembrados pelos dois professores, deve ser lembrado também o aspecto, defendido pelos três professores: a escolha também decorre da facilidade individual de cada um, pelo conforto sentido por cada instrumentista para executar desta ou daquela maneira, além das concepções musicais de cada músico. Como disseram, bom é o que funciona, bom é o que não machuca o corpo, o que não vai atrapalhar fisicamente no futuro. Somando-se a tudo isso, ainda existem as fortes influências dos professores de cada músico, de seus formadores, e também o gosto pessoal, tanto do mestre quanto do aprendiz.

Outra pertinente hipótese criticada pelo Prof. Dimos é a dissociação, feita no ensino tradicional da música erudita, da parte criativa com a parte técnica. Para ele, essa dissociação deixa o estudo pesado, impessoal, e é o que faz que muitos músicos desistam.

Um conceito valioso discutido por Goudaroulis foi a questão da importância da empatia e da amizade na relação de mestre para o aprendiz. Baseado em seus exemplos pessoais, questiona o professor que somente dá a matéria e passa os ensinamentos sem, necessariamente, criar uma boa relação pessoal, de apoio e de "trazer para si" o aluno. Fala que os professores também devem aprender a adaptar o ensino e o conhecimento transmitido a cada aluno, serem flexíveis com as identidades individuais e o histórico de estudo de cada um, a fim de incentivar o processo de aprendizagem de uma maneira mais eficiente.

Outra idéia muito importante para o aperfeiçoamento pessoal também foi abordada: a de buscar, no estudo diário, não somente o desenvolvimento das peças estudadas, mas em buscar, a cada dia, "ir mais longe", dentro do lado técnico, estético, artístico. A cada dia aprender algo novo e se aperfeiçoar, mais e mais.

Relacionado à interpretação, uma hipótese muito interessante apresentada foi a do estudo que simula uma situação de apresentação e de performance, tal qual seria. Estudar o ato da performance, imaginando que a platéia está assistindo, o que ela percebe, sentindo a música integralmente, com a mesma concentração de um recital ou concerto, do começo ao fim, e tentar não somente executar a peça, mas interpretá-la com corpo, alma, sensações, concepção. Essa prática parece, a esta pesquisadora, trazer uma série de novas sensações e novos controles emocionais ao simples estudo diário, em que se pára e se repete de novo o que não foi bem, e parece ser particularmente útil a 
quem se sente inibido ou mesmo em pânico com o fato de se apresentar. É um treino completamente diferente, um treino do processo de se apresentar.

\section{Professor Fábio Presgrave:}

Um ponto pertinente, abordado unicamente pelo Prof. Presgrave é o da velocidade do arco e o uso consciente dessa velocidade. Esse ponto, já defendido também, com veemência, pelo Prof. Rostropovich, no Primeiro Capítulo, é tratado por Presgrave como um dos maiores problemas dos violoncelistas brasileiros, e das orquestras brasileiras, e lembra que em orquestras como a Filarmônica de Berlim, por exemplo, esse tema é tratado com o máximo cuidado possível.

Rostropovich afirmou que é necessário fazer uso do arco inteiro, lembrando que "A diferença entre o gênio e o medíocre são os três centímetros de talão e os quatro de ponta que o medíocre nunca usa". Entretanto, não se deve interpretar essa afirmação de modo simplista, ou seja, que ele estivesse afirmando que sempre é necessário usar o arco inteiro. O exercício de escalas com diferentes números de notas ou de tempos por arco, que ele propôs e defendeu como um exercício para gerar a independência e o controle do arco nessa relação de peso, quantidade de arco, região de arco e velocidade, desmistifica completamente essa conclusão precipitada que poderia ser tirada, se se observasse apenas a primeira citação, sem ter observado o contexto, além do resultado gerado pelos exercícios acima propostos, também, por ele.

Outra idéia interessante abordada por Presgrave foi a importância de se trabalhar diretamente com compositores e que isso também influenciou grandemente sua formação teórica, visto que teve acesso direto à fonte das músicas estudadas e à maneira de o compositor pensar a sua obra.

A importância do estudo, do conhecimento e do contato com músicas recentes, $o$ estudo de peças compostas nos séculos XX e XXI, até mesmo por compositores vivos (não somente, como já foi dito, para ter acesso às idéias musicais do compositor, mas sim para conhecer as obras em si e explorar os diferentes timbres, os diferentes sons, a imensa gama de invenções e explorações feitas no instrumento), também foi lembrado como importante parte da formação de um músico pelo Prof. Presgrave.

O Prof. Presgrave também afirma pertencer à maneira de pensamento a que foi mais exposto em sua formação na Juilliard School of Music (EUA), pensando no 
violoncelo sem se basear em tradição empírica, mas, sim, em racionalização, em como fazer, na forma que ele funciona. Com certeza, aqui, ele não menospreza as tradições já estabelecidas no ensino e estudo, mas sim acredita que é necessário também um olhar que se desprenda ao máximo de tradições estabelecidas, com o intuito de encontrar novas idéias, novas percepções corporais, novas sensações, que dêem espaço à criatividade e à observação mais objetiva dos problemas apresentados, evitando usar fórmulas prontas e estabelecidas, sem uma reflexão prévia.

Outras idéias importantes mencionadas foram a de se evitar formar ângulos acentuados na relação braço, pulso e mão, tanto da esquerda quanto da direita, e que ele acredita também que o pulso da mão esquerda deve estar sempre na linha do cotovelo, e esta é uma idéia que ele afirma ser defendida também por Yoyo-Ma. Além disso, ele apresenta a idéia de que devemos sempre nos mover de grandes grupos musculares para pequenos.

Outra idéia que chama a atenção (e que também foi mencionada apenas pelo Prof. Presgrave) é o importante conceito do condicionamento de bons reflexos para se estudar bem: treinar o correto, treinar o que funciona, idéia também mencionada por Sazer, Mantel e Pleeth, no Primeiro Capítulo. 
Quarto Capítulo. Reflexões sobre aspectos do ensino do violoncelo 
Quarto Capítulo. Reflexões sobre aspectos do ensino do violoncelo

\author{
"Asincontáveis estrelas e constelações que hoje vemos \\ foram progressivamente formadas e descobertas, mas, \\ quanto mais połentes se łornarem os telescópios, mais \\ estrelas e vidas encontraremos. Portanto, quanto mais \\ temos o poder de ver, mais temos o que ver." \\ TENZIN GYATSO, Dalai-Lama
}

\title{
4. 1. O violoncelista "pesquisador"
}

Este trecho do trabalho pretende trazer retomar algumas idéias já tratadas e trazer outras, ainda não mencionadas, para o estudo diário, com a finalidade de auxiliar as buscas diárias do violoncelista por suas próprias idéias e constatações, que o tornam pesquisador e pensador de seu instrumento, de sua técnica. É claro que ainda existem infinitas possibilidades, porém, abaixo, esta pesquisadora (e também docente) pretende dar algumas idéias que podem vir a ser úteis.

$\mathrm{O}$ ato de estudar, aprender e ensinar qualquer instrumento, em particular o violoncelo, aqui tratado, como vimos, abrange inúmeros, provavelmente infinitos aspectos, alguns deles tratados tanto pelos autores pesquisados, quanto pelos professores entrevistados.

Vimos que é necessário, ao se estudar:

- Perceber cada vez mais o corpo em relação ao instrumento.

- Estudar criativamente os exercícios, músicas, ou o que quer que se esteja estudando, com a finalidade de gerar o maior conhecimento e desenvolvimento possível naquele estudo.

- Buscar um aquecimento e uma familiarização ao iniciar o estudo.

- Ter conforto na postura e na execução de qualquer tipo de aspecto da técnica.

- Buscar cada dia transcender os limites técnicos e estéticos.

- Evitar ficar estudando o que já se sabe. 
A seguir, serão propostas também algumas idéias básicas para se observar e buscar aprimoramento, no estudo diário:

1. Qualidade de som.

2. Timbre.

3. Relaxamento do corpo.

4. Relaxamento dos braços.

5. Relaxamento dos polegares.

6. Afinação.

7. Respiração fluente.

8. Respirações na música.

9. Frases.

10. Ponto de contato do arco na corda.

11. Vozes destacadas.

12. Limpeza do som, clareza de nota para nota.

13. Diferenças de dinâmica.

14. Articulações.

15. Diferenças claras de articulações.

16. Frases.

17. Buscar, dentro das frases, as "palavras", as "sílabas tônicas".

18. Buscar pontos de apoio nas frases (pontos de maior intensidade sonora) e pontos de relaxamento da frase.

19. Quantidade de crina que se deseja usar em cada momento.

20. Quantidade de arco necessária em cada momento.

21. Velocidade de arco adequada a cada momento.

22. Aderência do arco na corda, necessária a cada corda, e a cada momento.

23. Peso de braço necessário.

24. Mão esquerda leve.

25. Mão direita flexível.

26. Mão direita comandando (para fins de maior relaxamento da esquerda, e também para perceber e construir a frase com maior acuidade).

27. Coordenação perfeita entre a mão esquerda e a direita.

28. Quantidade e amplitude de som desejada a cada momento. 
29. Ritmo correto.

30. Pulsação.

31. Andamento.

32. Não deixar a linha de pensamento, a idéia musical e a linha de tensão da melodia se perderem.

33. Uso do vibrato bem pensado, tanto em quantidade quanto em amplitude.

34. Evitar o uso indiscriminado do vibrato.

35. Boa postura ao tocar.

36. Relaxamento das feições (rosto e boca), pois isso interfere também no relaxamento do pescoço e ombros, além de ser antiestético.

37. Sentimentos pedidos pela música naquele momento.

38. Sentimentos do músico naquele momento.

39. Buscar gerar expectativas ao se tocar.

40. Criar momentos de surpresa no ouvinte.

41. Ser claro, exagerar as idéias musicais.

42. Senso de continuidade ao se tocar movimentos ou passagens lentas.

43. Tocar livremente, ainda que no ritmo correto.

Além dessas idéias, inúmeras são as possibilidades de foco no ato do estudar. Contudo, deve-se estar atento para o fato de que é muito difícil tentar estudar várias idéias ao mesmo tempo, portanto, é de grande valor focar em um ou em alguns poucos itens a cada momento, no ato do estudo.

Uma grande recomendação que foi feita, certa vez, de um mestre para esta aprendiz, também poderá ser extremamente útil: buscar altos padrões para se inspirar, ou seja, ouvir muitas gravações e execuções dos grandes músicos, grandes solistas, grandes regentes, grandes orquestras, grandes grupos de câmara, buscar as melhores gravações possíveis, bem como a maior quantidade possível de execuções de uma mesma obra.

Deve-se também procurar o melhor professor ou professora possível (aquele com quem temos grande identificação, seja de idéias, seja musicalmente, seja pelo impacto que a performance dele ou dela nos causa), para que também tenhamos cada vez padrões mais elevados para inspirar nossa própria performance. 
Outra importante recomendação, também transmitida oralmente, de uma mestra para esta aprendiz, foi a de jamais acreditar que se toca muito bem. Sempre é possível evoluir muito. E isso não diz respeito a assumir uma atitude de insatisfação passiva, mas sim de elevar os níveis de exigência para um aprimoramento. "Sempre haverá muita gente tocando pior que nós, sempre haverá gente tocando muito melhor do que nós", dizia ela. A sensação de satisfação pode gerar entusiasmo para o estudo, mas deve ser vista com cautela, pois pode levar à estagnação. Essa professora dizia: "Se achar que está tocando bem o violoncelo, pode comprar um trombone, pois você não aprenderá mais nada no violoncelo".

Outra recomendação: nos corredores do Teatro Municipal de São Paulo, ao ser elogiado por sua grande garra e empenho ao tocar no concerto da Orquestra, este grande mestre violista respondeu: “A gente tem que se divertir, não é?” E essa talvez seja uma das maiores diferenças entre os grandes músicos e os "medíocres": os grandes amam o que fazem, se divertem, se envolvem, estão realmente presentes, com o que Pleeth chamou de união mente-corpo-espírito.

Em entrevista para a TV, certa vez, o escritor português José Saramago, Prêmio Nobel de Literatura, ao ser perguntado sobre quais seriam as recomendações que ele faria a um aspirante a escritor, respondeu que seriam três: a primeira, ler muito; a segunda, ler muito; a terceira, ler muito. Esta pesquisadora, fazendo um paralelo com as idéias de Saramago, poderia dizer uma última recomendação: ouvir muito (em todos os sentidos), ouvir muito, ouvir muito. 


\subsection{Alguns problemas do ensino do violoncelo no Brasil}

Uma lacuna imensa, lembrada neste trabalho, é a total ausência de trabalhos publicados, no Brasil, sobre o violoncelo, sobre a interpretação do instrumento, sobre a técnica, sobre a prática: ou seja, o violoncelista brasileiro se encontra em um campo a ser "desbravado". Faltam traduções, faltam trabalhos acadêmicos, faltam livros e falta interesse de editoras. É um campo totalmente aberto a explorações e a se desenvolver.

Outra lacuna a ser lembrada novamente é a da falta de investimentos em ensino básico (e isso também inclui o ensino básico musical, teórico e de instrumentos), que possibilitariam formar inúmeros indivíduos capazes de apreciar, amar e valorizar a arte, como profissão (para si e para os outros), permitindo um conseqüente aumento da quantidade de orquestras, grupos, escolas de música, salas de concerto, já que a carência de contato com a música (principalmente a erudita), como lembrou bem o Prof. Presgrave, "como uma coisa natural”, proporciona uma série de distorções na visão que o brasileiro tem de instrumentos ditos "eruditos", como o violoncelo.

Qualquer músico brasileiro sabe dessa situação e vive na pele, com freqüência, situações em que as pessoas os param na rua para perguntar qual instrumento carregam, pois não têm idéia nenhuma de qual seria e, muitas vezes, uma resposta como "É um violoncelo", não tem qualquer significado, dada a total ausência de instrumentos de orquestra em sua realidade diária.

Como esperar que um cidadão que jamais viu uma banda, uma orquestra, um quarteto de cordas, um quinteto de sopros, ou um recital fique satisfeito com a prefeitura de sua cidade investindo milhares de reais mensais, por exemplo, em uma orquestra à qual ele não tem acesso, ou à qual não se julga no direito de assistir, por acreditar ser algo de "elite"? Como esperar que esse cidadão aprecie que seu filho estude horas e horas por dia um instrumento musical, e que esteja consciente do esforço e dedicação necessários para se atingir um nível razoável de desenvolvimento, se ele não tem acesso a um emprego digno ou, até mesmo, se não tem acesso à educação básica necessária?

Todos os Professores entrevistados chamaram a atenção para esses problemas e declararam a admiração pelos esforços isolados que acontecem, tais como, principalmente, o Projeto Baccarelli, o Projeto Pão de Açúcar, os CEUS, que, embora todos saibam que poderiam funcionar ainda muito melhor se houvesse um investimento 
sério na educação, levantam possibilidades para uma educação musical mais bem realizada.

Esta pesquisadora também não pode deixar de lembrar o trabalho importante feito por inúmeras igrejas evangélicas (ainda não mencionado) nos últimos anos, que tem dado acesso ao aprendizado musical, a preços acessíveis ou até gratuito, a quem desejar. Esse trabalho didático, muitas vezes de boa e até mesmo de excelente qualidade, tem sido responsável por uma conseqüente profissionalização de uma grande quantidade de músicos de orquestra e de câmara.

Contudo, é necessário (e vergonhoso) afirmar que a situação no país é realmente desoladora e que, ainda, o eixo Rio-São Paulo é um dos poucos lugares do Brasil com certa efervescência musical, mas que, pela imensidão do país e pela quantidade de sua população (sem deixar de mencionar a quantidade de pessoas que amam a música), é uma "efervescência" ainda muito inexpressiva. É difícil, verdadeiramente, como lembraram os Professores, que essa situação se inverta, a não ser que se façam esforços individuais e projetos coletivos realmente marcantes e a não ser que os professores tomem essa "bandeira" para si e para seus aprendizes: a de um ensino bem feito, cuidadoso, bem embasado.

Os três Professores entrevistados no Terceiro Capítulo se mostram, nessas entrevistas, claramente, "carregadores dessas bandeiras", como muitos outros profissionais competentes que existem pelo país. Mas, para que haja maior progresso do que poderia vir a ser uma "Escola Violoncelística" no Brasil é necessário que haja, cada vez mais, uma proliferação de bons violoncelistas (no caso específico deste instrumento, mas seria uma verdade para todos os demais instrumentos também), de pessoas que invistam pesadamente em sua própria formação pessoal (técnica e artística), na formação de seus alunos, em estudo, em prática de todos os tipos, em leituras e em prática de performance.

\section{3. Lecionar o violoncelo: a transmissão oral de mestre para aprendiz}

A aula de violoncelo é, na grande maioria das vezes, uma transmissão de conhecimentos feitos pela tradição, memória e história oral, que passa de professor para aluno, que, futuramente, pode se tornar um novo professor e continuar a transmitir o que aprendeu. Trata-se de uma antiqüíssima maneira de transmitir dados, a importante 
relação de mestre-aprendiz, que tem permeado toda a história da humanidade, e que foi pertinentemente lembrada pelo Prof. Goudaroulis, em sua entrevista.

Especialmente em lugares como o Brasil, também como foi lembrado pelos três Professores entrevistados, onde não existe grande tradição de música erudita, não existem grandes escolas formadoras (pelo menos não reveladas por pesquisas) de violoncelo. Assim, essa tradição oral torna-se, às vezes, principal fonte de aprendizagem para um violoncelista em formação.

A Professora Dra. Ecléa Bosi (aqui esta pesquisadora pede licença para explicitar abertamente sua admiração), na brilhante introdução seu livro Memória e Sociedade - Lembranças de velhos (Op. cit., 2004), trata dessa relação entre mestre e aprendiz, dessa situação em que se transmitem oralmente, e pessoalmente, os ensinamentos e a experiência pessoal aprendidos por cada um, por meio de relatos da memória individual, nesse caso aqui tratado, do mestre. Ela cita Hegel, que acreditava que:

"é o passado concentrado no presente que cria a natureza humana por um processo de contínuo 'reavivamento' e rejuvenescimento. (...) Os projetos do indivíduo transcendem o intervalo físico da sua existência: ele nunca morre tendo explicitado todas as suas possibilidades. Antes, morre na véspera: e alguém deve realizar suas possibilidades que ficaram latentes, para que se complete o desenho de sua vida $(2004$, p. 75$)$ ".

Ela cita também Halbwachs, que diz, ao tratar da transmissão da memória, por meio de relatos: "O caráter livre, espontâneo, quase onírico da memória é (...) excepcional. Na maior parte das vezes, lembrar não é reviver, mas refazer, reconstruir, repensar, com imagens e idéias de hoje, as experiências do passado. A memória não é sonho, é trabalho. (2004, p. 55)

Por isso, o que se transmite em aulas não é apenas a memória do mestre, mas uma memória reconstruída na situação da aula, reconstruída pelo momento presente, sob a visão daquele dia, naquela aula.

Esta memória reconstruída é, também, por conseguinte, adquirida pelo alunoouvinte, sob a lente de sua própria perspectiva e, novamente, é transformada a cada ato do estudo individual, em cada momento de reflexão a respeito dessa informação, transformando-se em nova memória viva e sujeita às transformações e reconstruções dessa pessoa. Dessa maneira, o conhecimento está se transformando todo o tempo e jamais permanece estático. 
Com essa informação recebida, o aluno vai para seu instrumento, experimentála, percebê-la, avaliá-la, por sua experiência pessoal e, desta "pesquisa" no instrumento, busca tirar suas próprias conclusões. Esta pesquisadora acredita ainda que nenhuma conclusão verdadeira é obtida sem esse processo de experimentação, de pesquisa individual de seu corpo, suas reações, sua percepção, inclusive auditiva. Além disso, o violoncelista que não faz essa "pesquisa", que não tira as próprias conclusões e, também, que não se apresenta constantemente (também para tirar conclusões reais da eficácia de seu conhecimento, no momento da único da performance), aquele que não está sempre em busca de idéias melhores, não será, de modo algum, um bom educador.

E o contrário também se dá: bons professores são sempre "pesquisadores" de seu próprio instrumento, bons alunos são "pesquisadores", bons violoncelistas são “pesquisadores", e, como exemplificado pelas entrevistas dos Professores, anteriormente, os três concordam com um assunto muito importante, já exposto pelas idéias de Sazer, no Primeiro Capítulo: estão sempre abertos a testar novas idéias, divergentes das suas. Essa é, com certeza, uma das características de um bom artista, seja intérprete, educador, seja ambos.

Outra característica fundamental de um bom músico, não importa em que área atue, é, essencialmente, seu amor pela arte, pela música, que o faz perseguir a idílica perfeição, mesmo consciente que nunca a encontrará, o amor pelo que faz e o entusiasmo que decorre desse amor. Mas não é um amor pelo "aperfeiçoamento pessoal", como um tipo de ganho social, ou até mesmo de capital (já que um músico melhor inevitavelmente acaba ganhando melhor, trabalhando mais), mas sim, que é movido pelo ideal, pelo amor à sua arte. O antigo conceito da "Arte pela arte".

Adverte-se que existe um "deslize" sutil que pode decorrer dessa busca pelo aperfeiçoamento, tratado com muita propriedade por Hannah Arendt, em seu texto “Crise na Cultura: sua importância social e política" (Op. cit., 2000). Nesse texto, a autora destaca uma importante idéia: posteriormente a uma emancipação social através do dinheiro, o "burguês" (como é chamado por ela a pessoa de Classe Média) pôde “comprar" sua cultura, ou seja, pôde absorver conhecimentos novos pela sua capacidade de ir a teatros, óperas, concertos e balés, bem como adquirindo e lendo livros, comprando quadros e objetos de arte, e até mesmo fazendo cursos. Isso fez a população poder, também, adquirir um novo status e posição social, em cima de, digamos, sua 
riqueza cultural e sua riqueza material, gerada pelo acúmulo de "cultura". Ou seja, poder comprar e consumir cultura também se tornou sinônimo de ascensão social.

O artista, para a autora, foi o indivíduo que restou na sociedade de massa, pela seguinte razão:

"de ser ele, afinal, o autêntico produtor daqueles objetos que toda a civilização deixou atrás de si como a quintessência e o testemunho duradouro do espírito que nos animou. Justamente o fato de os produtores dos objetos culturais máximos, ou seja, as obras de arte, precisarem se voltar contra a sociedade, e o fato de todo o desenvolvimento da arte moderna - que provavelmente ficará, juntamente com o progresso científico, como uma das maiores realizações da nossa época - ter se iniciado dessa hostilidade contra a sociedade (...), demonstra a existência de um antagonismo entre sociedade e cultura, anterior ao ascenso da sociedade" (Op. cit., 2000)

Ela também faz contraste entre o objeto produzido pelo trabalho não criativo, que seria um objeto de consumo, contra o objeto produzido pelo trabalho criativo: o objeto de arte. E arte boa seria, segundo Arendt, a arte que perdura através dos tempos, a verdadeira obra de arte: a que tem o poder de "apoderar-se do leitor ou do espectador, comovendo-o durante os séculos".

A idéia que mais nos interessa, para repensar a nossa educação e a educação que propomos aos outros, nesse texto, é a que Arendt afirma que:

"As grandes obras de arte não são pior utilizadas, ao servirem a fins de auto-educação ou de auto-aperfeiçoamento, do que ao se prestarem a qualquer outra finalidade; pode ser tão útil e legítimo contemplar uma pintura para aperfeiçoar o conhecimento que se possui de um determinado período, como utilizá-la para tapar um buraco na parede".

O trecho a seguir explica melhor esse pensamento da autora, a respeito do uso do conhecimento e da educação como um outro tipo de forma de consumo, ou de aquisição de bens, o que ela chama de filisteísmo:

\footnotetext{
"O que irritava no filisteu educado não era que ele lesse os clássicos, mas que o fizesse movido pelo desejo de auto-aprimoramento, continuando completamente alheio ao fato de que Sheakespeare e Platão pudessem ter a dizer-lhe coisas mais importantes do que a maneira de se educar".
}

A diferença da sociedade e a sociedade de massas, segundo a autora, talvez seja, então, que a sociedade sente a necessidade de cultura, valoriza e desvaloriza objetos culturais na medida em que os transforma em mercadorias, em "proveito de seus fins 
mesquinhos", e a sociedade de massas, ao contrário, não precisa de cultura e sim de diversão, para ser consumida.

Nisso é gerada uma sutil controvérsia: a diversão necessita de novidade e ineditismo, e a arte pode até ser inicialmente novidade e ineditismo, mas é principalmente aquilo que emociona e que perdura. "Do ponto de vista da mera durabilidade, as obras de arte são claramente superiores a todas as demais coisas" (Op. cit., 2000). Hannah Arendt chama a atenção, então, para um problema que decorre desse consumo da cultura pela sociedade e pela sociedade de massas: uma transformação da cultura e das obras de arte para que elas sejam mais facilmente compreendidas, mais rapidamente absorvidas, como, por exemplo, o resumo de grandes clássicos da literatura, as coletâneas de músicas eruditas nos chamados "Clássicos Populares", a banalização de grandes obras da música erudita, feitas por alguns músicos.

A cultura é, assim, vendida e consumida, de uma maneira desrespeitosa, que leva as pessoas a acreditarem que conhecem as obras, sem, contudo, terem se dado a oportunidade de se emocionarem com a totalidade delas, com uma grande execução, ou com sua riqueza de detalhes.

Como artistas, devemos também observar, assistir, ler, ouvir, aprender, é claro, mas o verdadeiro artista não está somente preocupado em aprender, para se enriquecer culturalmente, mas sim em fazer o que ama, o mais bem feito possível, fazer o que ama porque o ama. $\mathrm{O}$ grande educador também deve estar atento a incentivar seu aluno a pesquisar, estudar, ler, ouvir, conhecer, sem esta finalidade duvidosa de "adquirir" o conhecimento como se fosse um bem de capital que o engrandeça, mas com a finalidade de perseguir a arte como a uma paixão, buscar sentido naquilo que toca, "tocar" realmente, o coração, o seu e o dos outros, o de seus ouvintes, ou alunos.

Deve-se buscar não somente momentos corriqueiros em que se inspira e expira, mas aqueles em que é incapaz de respirar, devido à comoção. Retornar àquela antiga condição da palavra "amador", como sendo apenas aquele que ama, mesmo que já tenha se profissionalizado, sendo um transmissor desse amor que motivou, inicialmente, todos os que são artistas, a transformarem seu mundo e, dessa forma, o dos outros. 
O único educador que incentiva seu aluno, verdadeiramente, é o educador que ama o que faz e o único educador que move a sociedade, para mudanças realmente boas e significativas, é o educador apaixonado, que se comove e que faz comover. 
CONSIDERAÇÕES FINAIS 


\section{CONSIDERAÇÕES FINAIS}

"Eu não sou jovem suficiente para saber de łudo".

OSCAR WILDE

Na biografia de Pablo Casals, intitulada Casals, escrita por Josep M. Corredor (Op. cit., 1987), o autor nos conta que quando Casals chegou a Barcelona, para estudar na Escola Municipal de Música, muito jovem, ainda que tenha iniciado seus estudos com grande afinco, logo percebeu que, para se tocar violoncelo segundo os cânones da época, o executante deveria se submeter ao que o autor descreve como "uma série de extravagâncias e convenções absurdas". Segundo Corredor, Casals seguia os cursos com grande atenção, mas em casa iniciava uma revisão paciente e meticulosa, a elaboração de uma nova técnica.

E cita a maneira como Casals se recordava do fato:

"Então nos obrigavam a manter o braço rígido, e nos ensinavam a tocar com um livro debaixo do sovaco. Para quê tudo isso? Eu quis dar a máxima flexibilidade à ação do braço direito, e a tal efeito introduzi o movimento do cotovelo - frente ao assombro dos tradicionalistas, que o consideravam um escândalo -, movimento que reforça e facilita o manejo do arco. Também empreendi uma revisão da digitação, da posição e da função dos dedos da mão esquerda, inspirando-me no que me parecia mais simples e natural. A natureza, a vida, transbordam de ensinamentos para aquele que queira observá-la humilde e diligentemente." (1987, p. 24)

O autor da biografia também conta que seus companheiros não compreendiam Casals, como é de praxe acontecer com os inovadores, lhe advertindo que "ele veria mais tarde as conseqüências". Josep Corredor afirma que o certo é que, atualmente, em todos os conservatórios do mundo, se ensinam os princípios básicos do que ele chama de "técnica Casals", técnica essa, contudo, que o autor da biografia não descreve ou detalha e que apenas comenta como sendo uma técnica que esteve e está em constante evolução, para a qual nunca se assinalaram alvos definitivos.

Casals, com essas idéias, mostra que, como também o afirmaram os professores entrevistados nesta pesquisa, antes de qualquer coisa, o violoncelista (qualquer um, em qualquer nível de desenvolvimento, tanto técnico quanto artístico) deve pesquisar. 
Pesquisar testando, sentindo movimentos corporais e técnicos, além de observar, ler, estudar, ouvir muita música, assistir concertos e recitais (de quaisquer instrumentos: isso é extremamente importante e foi bem frisado pelos Profs. Presgrave e Goudaroulis), observar todos os tipos de manifestação artística e musical, fazer sempre aulas para se atualizar, ou seja, colocar em uso todas as ferramentas disponíveis de conhecimento artístico e cultural, para seu aperfeiçoamento artístico.

No início do livro Casals and the art of interpretation, escrita por David Blum (Op. cit., 1987), o autor cita uma frase de Casals: "Imagine!(...) Me chamam de grande cellista; eu sou um músico. Isso é muito mais importante. ${ }^{50 "}(1987$, p. X)

O cellista deve buscar ser, antes de tudo, um músico, um artista. E este, por conseguinte, deve ser antes de tudo um pensador, uma pessoa que observa e que sente. Deve e pode fazer uso, também, de todos os meios modernos de pesquisa, incluindo-se aí o $\mathrm{CD}$, o DVD, os atuais equipamentos portáteis, que permitem estudar música ouvindo-a onde quer que se vá, bem como deve fazer uso de sites que permitam ler, assistir, ouvir e baixar da Internet gravações, vídeos, entrevistas, performances, aulas, teses e artigos, aproveitando-se do fato de que essas modernas ferramentas de difusão de conhecimentos nunca estiveram tão disponíveis a tantas pessoas, em tão grande quantidade, às vezes gratuitamente, ou com preços decrescentes, devido às constantes atualizações.

Deve-se lembrar também que, há pouco mais de cem anos, um estudante de violoncelo não podia estudar a maneira de interpretar de um grande solista a não ser que o assistisse pessoalmente, naquela performance única que não se poderia repetir jamais. Portanto, o privilégio de quantidade de fontes de aprendizado musical de que dispomos hoje é incomparável a qualquer outro período da história do homem e proporciona a possibilidade de aprendizado a um número, também, cada vez maior de pessoas, bem como um público cada vez maior que tem acesso, privilegia e gosta de arte e, até mesmo, faz dela parte de sua vida quotidiana, por meio dessas novas tecnologias.

Por outro lado, dada a gigantesca quantidade de informações disponível, deve-se ter um empenho comparável para absorvê-las, para se aproveitar cada vez mais os meios disponíveis de aprendizado e de pesquisa. Como já foi dito antes, o instrumentista é sempre um autodidata, pois não aprende realmente uma idéia, ou conceito, a menos que

\footnotetext{
50 “'Imagine!' Pablo Casals once said. 'They call me a great cellist; I am a musician. This is much more important." "
} 
experimente essa idéia e a vivencie, que a sinta em seu corpo, em seu arco, em seu instrumento. Por essa razão, a pesquisa no instrumento (o estudo pessoal do violoncelo) ainda é a melhor (e incomparável) forma de se aprender e ter intimidade crescente com seu funcionamento.

Voltamos aqui ao paradoxo entre o moderno e o antigo: assim como um luthier, que não tem como fazer seu instrumento a não ser se utilizando das antigas maneiras que os primeiros luthiers da história o faziam, ou seja, devagar e pacientemente, a cada etapa, seguindo algumas regras e padrões pouco mutáveis: também a arte do instrumentista necessita de um passo a passo de descobertas e aprendizados, de percepções e também tempo e maturidade para realizar o que outros mais experientes já realizaram, ou até mesmo o que ninguém jamais ousou realizar.

A relação de aprendiz e mestre, comentada anteriormente, é talvez tão antiga que deve, provavelmente, ter se originado na relação entre pai e filho, e é ainda muito forte para um aprendiz de um instrumento, com relação a seus mestres. Basta observar, no Terceiro Capítulo, a importância atribuída, pelos Professores entrevistados, a seus mestres.

É necessário observar também que dispomos de outros meios modernos para se aprender, além de toda a tecnologia acima mencionada: além dos livros, da prática individual, da prática de orquestra e de grupos de câmara de todos os tipos, ainda podese lembrar de algumas outras ferramentas muito úteis, também tecnológicas, nem tão modernas assim, para se aprender: o metrônomo, o afinador, o espelho (aqui, não com o sentido da parte do braço do violoncelo, mas o espelho, no sentido comum, refletor de imagens), o gravador e a filmadora.

Todos esses elementos são indispensáveis para adquirir uma reflexão saudável sobre a própria técnica e o aprendizado, pois aperfeiçoam a percepção do que está sendo interpretado e de como, verdadeiramente, está sendo interpretado. Além de tudo, proporcionam perspectivas e visões "de fora", o intérprete fora de si mesmo, como se este pudesse ser seu ouvinte externo ou sua própria platéia. É necessário lembrar que a percepção do que se está tocando é sempre mesclada com a expectativa do que se quer atingir, com o já tratado "conceito-meta" a que o músico se propôs e que, quase sempre uma filmagem, ou gravação de si mesmo pode causar um grande espanto. 
Por isso, hoje, o violoncelista, como em outras épocas, mas com mais recursos disponíveis, pode ser também o mestre de si mesmo (ainda que nada substitua a relação de um verdadeiro mestre com um aprendiz realmente disposto a aprender), pois dificilmente se chegará a alguma conclusão verdadeira sobre determinado tema, ou se chegará a alguma idéia nova, sem a real experimentação pessoal. O estudo do instrumento não deve ser uma repetição de atos previstos e determinados, mas uma reflexão constante. A pesquisa deve ser considerada o resultado de busca, indagação, exame, análise. Piaget já trouxe, anteriormente, a idéia de que não é o professor que ensina, é o aluno que aprende.

Por isso, a "pesquisa" no violoncelo (assim como em qualquer outro instrumento) deve ser tratada com a seriedade de uma atividade científica, que é definida por Salomon (1997, p. 135) como "aquela que produz ciência, ou dela deriva, ou acompanha o seu modelo".

Também por essa grande disponibilidade de informações, hoje em dia, é totalmente inútil (além de mesquinho) "sonegar" informações, tanto para alunos quanto para colegas. As aulas de Rostropovich são prova de que um grande professor dá com generosidade, independentemente de quem vai receber e de quem vai aplicar. Os meandros e os caminhos que a cultura e a educação percorrerão são de ramificações infinitas e é impossível calcular o impacto benéfico de uma grande idéia, ou até mesmo de uma pequena boa idéia.

Certa vez, em uma aula recebida por esta pesquisadora, ministrada por Raiff Dantas Barreto (spalla dos violoncelos da Orquestra Sinfônica Municipal de São Paulo), este mestre contou que ao dar um curso, em um Festival de Música no nordeste do Brasil, recebeu um aluno iniciante que havia aprendido a tocar o pouco que tocava no violoncelo apenas observando uma fotografia de um violoncelista (único meio de que dispunha), e deduziu daquela posição, feita pelo cellista, qual seria a posição correta, imitando-a e buscando, por meio somente daquela foto, elementos para encontrar as notas, "de ouvido". Conseguia tocar, mesmo sem nenhum mestre, ainda que com muita dificuldade e muitos problemas, que poderiam ser evitados se houvesse uma maior quantidade de bons professores, disponíveis em todo o Brasil.

Conclui-se, além da triste constatação da imensa precariedade de recursos de educação a que a grande maioria dos brasileiros ainda está submetida, que uma pequena 
informação pode ser transformada em uma informação de valor incalculável. E que a força de vontade (disciplina) e a pesquisa (reunião de informações e reflexão sobre as mesmas, composto desse processo de síncrese-análise-síntese), pode ser transformada em arte (expressão única e individual, que toca a coletividade).

Como disse, certa vez, Guimarães Rosa: "A colheita é comum, mas o capinar é sozinho". 


\section{BIBLIOGRAFIA}




\section{BIBLIOGRAFIA}

\section{- Livros Pesquisados:}

ALEXANIAN, Diran. Complete cello Technique - The classic Treatise on Cello Theory and Practice. Dover Publications: New York, 2003.

ARENDT, Hannah. "Crise na Cultura: sua importância social e política". In: Entre o passado e o futuro. Ed. Perspectiva: São Paulo, 2000.

BALES, Dorothy. "String Playing by the way of the brain: left, right and center". In: American String teacher. Summer, 1993.

. "String Playing by the way of the brain: left, right and center - Part

2”. In: American String teacher. Autumn, 1993.

BOSI, Ecléa. Memória e Sociedade - Lembranças de Velhos. Companhia das Letras: São Paulo, 2004.

BORGES, J. Luis. Obras Completas. Vol. II. Elogio de la Sombra. Ed. Emecé:

Barcelona, 1996.

BOYDEN, David. "Bow”. In: The New Grove Dictionary of Music and Musician, Vol III. 1980.

BLUM, David. The Guarneri Quartet - The art of Quartet Playing. Editora Cornell: New York, 1987.

. Casals and the art of interpretation. California: Los Angeles, 1980.

BRUSER, Madeline. The art of Practicing - A guide to making music from the heart. Bell Tower: New York, 1997.

BUNTING, Christopher. Essay on the craft of Cello Playing - Prelude, Bowing, Coordination. Vol.1. Cambridge University Press: Cambridge, 1982. Essay on the craft of Cello Playing - The Left Hand. Vol.2.

Cambridge University Press: Cambridge, 1982.

CAMPBELL, Margareth. The great cellists. Trafalgar Square Publishing: Vermont, 1988.

CANDÉ, Roland de. Os Músicos, a vida, a obra, os estilos. Editora Martins Fontes: São Paulo, 1985. 
CHICK, Davoren. "Injury prevention for violists". In: American String Teacher. Autumn, 1988.

CONABLE, Barbara. What every musician needs to know about the body. Andover Press: Oregon, 2000.

COPLAND, Aaron. Como escuchar la música. Fondo de Cultura Econômica: México, 1986.

CORREDOR, Josep M. Casals. Editora Salvat: Barcelona, 1987.

CORTOT, Alfred. Curso de Interpretação. Editora Musimed: Brasília, 1986.

COWLING, Elisabeth. The cello. Charles Schribner's Sons: New York, 1975.

DOURADO, Henrique Autran. O arco dos instrumentos de cordas. 1ª Edição, Edicom:

São Paulo, 1998.

ECO, Umberto. Como se faz uma Tese. Editora Perspectiva: São Paulo, 2000.

FRANKLIN, Neshama. "Back problems and solutions". In: American String Teacher. November/ December, 1999.

FREIRE, Paulo. Pedagogia da Autonomia - Saberes necessários à prática educativa. Editora Paz e Terra: São Paulo, 1996.

GIANETTI, Eduardo. Auto-engano. Companhia de Bolso: São Paulo, 1997.

GONÇALVES, Hortência de Abreu. Manual de Metodologia da Pesquisa Científica. Editora Avercamp: São Paulo, 2005.

GYATSO, Tenzin, Dalai-Lama. Dalai Lama todos os dias - 365 meditações diárias. Ed. Versus: Campinas, 2005.

HAMITHZSCH, Horst. O Zen na arte da cerimônia do chá. Editora Pensamento: São Paulo, 1997.

IRVINE, Jeffrey. "Avoiding and recovering from bow arm and upper torso injuries". In: American String Teacher. Winter, 1991.

. "Avoiding and recovering from left-hand injuries". In: American

String Teacher. Summer, 1990.

LAVIGNE, Marco et Paulo Bosísio. Técnicas Fundamentais de Arco para Violino e Viola. Não publicado: Rio de Janeiro, 1999.

LIEBERMAN, Julie Lyonn. You are your instrument. Huiksi Music: New York, 1991.

LYNN, Stacey (editor). 21th Century Cellists. String Letter Publishing: San Anselmo, California, 2001. 
MANTEL, Gerhard. Cello Technique. Indiana Music Press: Indiana, 1995.

MARKEVITCH, Dimitri. Cello Story. Summy-Brirchard Inc.: Miami, 1984.

MENUHIM, Yehudi. Unfinished Jouney. Futura Publications Limited: Londres, 1976.

MORRIS, William. The American Heritage dictionary of the English Language.

Houghton Mifflin Ed.: Boston, 1991.

NORRIS, Richard. "Overuse injuries - How string players can recognize, prevent and treat them". In: American String Teacher. Data não encontrada.

PLEETH, William. Cello. Kahn \& Avril: London, 2002.

PRIETO, Carlos. As aventuras de um Violoncelo. Editora UniverCidade: S.P., 2001.

SALOMON, D. V. Como fazer uma monografia: elementos de método do trabalho cientifico. 5.ed. Belo Horizonte: Interlivros, 1977.

SAZER, Victor. New directions in cello playing. Ofnote: Los Angeles, 1995.

SUETHOLZ, Robert J. Aspectos da Técnica Violoncelística da mão esquerda. Artigo elaborado para o Curso de Mestrado na NorthWestern University, e traduzido pelo autor. São Paulo, 1999.

SUZUKI, Schnichi. Nurtured by love. Exposition Press: N. Y., 1994.

TOMPSON, Paul. "A voz do passado - A história oral”.

TORTELIER, Paul. El Violonchelo, asi interpreto, así enseño. Editora Labor: Barcelona, 1993.

WASIELEWSKI, W. Joseph. The Violoncello and its history. Da Capo Press: New York, 1968.

WILSON, Elizabeth. Jacqueline du Pré. Arcade Editor: New York, 1998. 


\section{- Métodos de Violoncelo pesquisados:}

BRAGA, Gaetano. Método per Violoncelo di G.G. F. Dotzauer interamente riformato da Gaetano Braga. Edizioni Ricordi: Milano, sem data.

BOSANQUET, Caroline. The secret life of Cello Strings: Harmonic for Cellists. SJ. Music: Cambridge, 1996.

COSSMANN, Bernard. Violoncello Studien. Ed. Schott: Germany, Copyright de 1912. DOTZAUER, G. G. F. et Klingenberg. Violoncello Schule. Peters Edition: New York, sem data.

. 113 Studies. Carl Fisher Inc.: New York, 1994.

DUPORT, J. L. 21 Exercises. Augener's Edition: England, Copyright de 1913.

FEUILLARD, Louis. Tägliche Übungen. Ed. Schott: Mainz, Copyright de 1919.

JENSEN, Hans Jorgen. The Ivan Galamian Scale System for Violoncello. E. C. S. Publishing: Northwest, 1994.

GRUTZMACHER. Daily Exercises for the cello. G. Schirmer: New York, Copyright de 1891.

GUERRERA, Anthony. Cello Method. M.M. Cole Publishers: Chicago,1936.

LEE, Sebastian. Cello Method. Carl Fischer: New York, sem data. . Melodic Studies. Schirmer's Library: New York, Copyright de 1939. . Melodische Lagenstudien. Edition Peters: Leipzig, 1969.

KLENGEL. Daily Studies. Schirmer's Library: New York, sem data.

KREUTZER, Rodolphe. 22 Studies. Transcritos por Dehn huellweck. International Music Company: New York, sem data.

KUMMER, F. A. 10 Melodische Etüden, opus 57. C. F. Peters: Frankfurt, 1958.

MERK, Joseph. Twenty Exercises for Violoncello. Schirmer's Library: New York, Copyright de 1902.

PIATTI, Alfredo. 12 Caprices. I. M. C.: New York, Copyright de 1974.

POPPER. Fifteen Studies for the cello. Kalmus-Belwin Mills: Melville, sem data. High School of Cello Playing. Schirmer's Library: N. Y., Copyright de 1967.

RABAUD, Henry. Méthode complete de Violoncelle. A.Leduc Éditeur: Paris, 1958.

RAPP, Eugene. Alte Meisterweisen. Ed. Schott: Mainz, 1969. 
STARKER, Janos. An Organized Method of String Playing. Peer Int.: NewYork, 1965.

SUCH, Percy. Alte Meister Für Junge Spieler. Schott Söhne: Mainz, 1941.

SUZUKI, Schinichi. Cello Method. Warner Bros. Publications: Miami, 1992.

\section{- Sites Pesquisados:}

JANOF, Tim. Conversation with Victor Sazer. Disponível em:

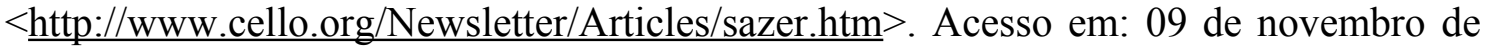
2007.

Conversation with Gerhard Mantel. Disponível em:

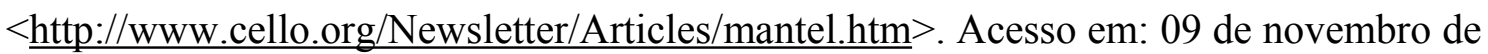
2007.

- Conversation with Mstislav Rostropovich. Disponível em:

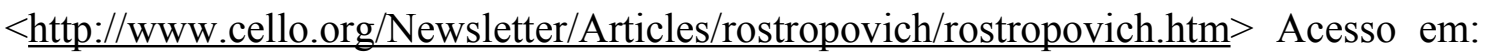
13 de novembro de 2007. 
ANEXOS 
1. Exercícios propostos a esta pesquisadora por Mstislav Rostropovich (digitados) 


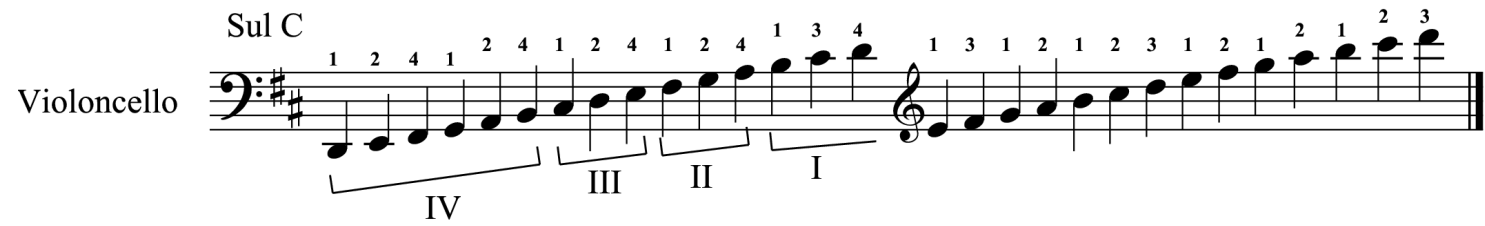
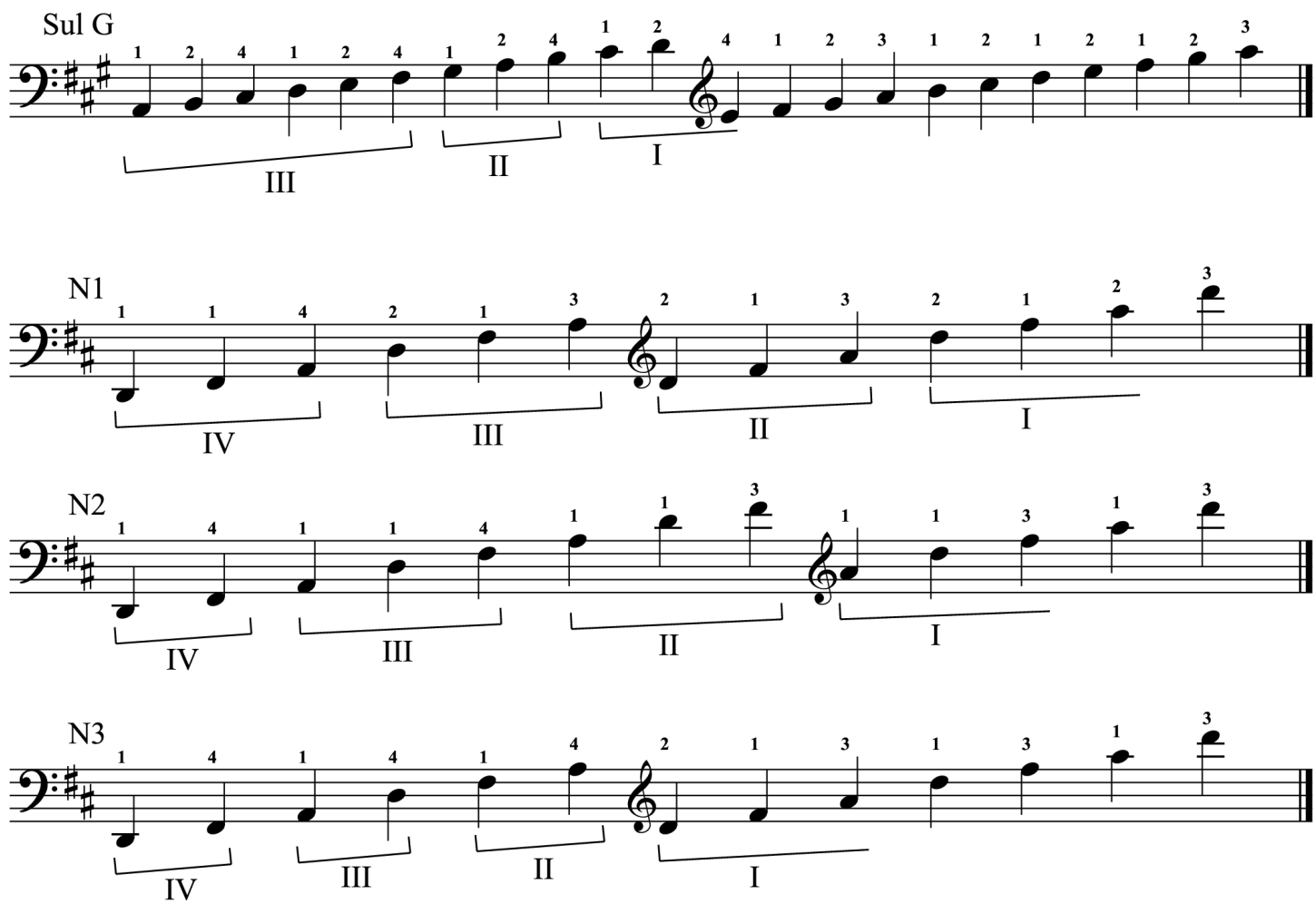

Sequencia A
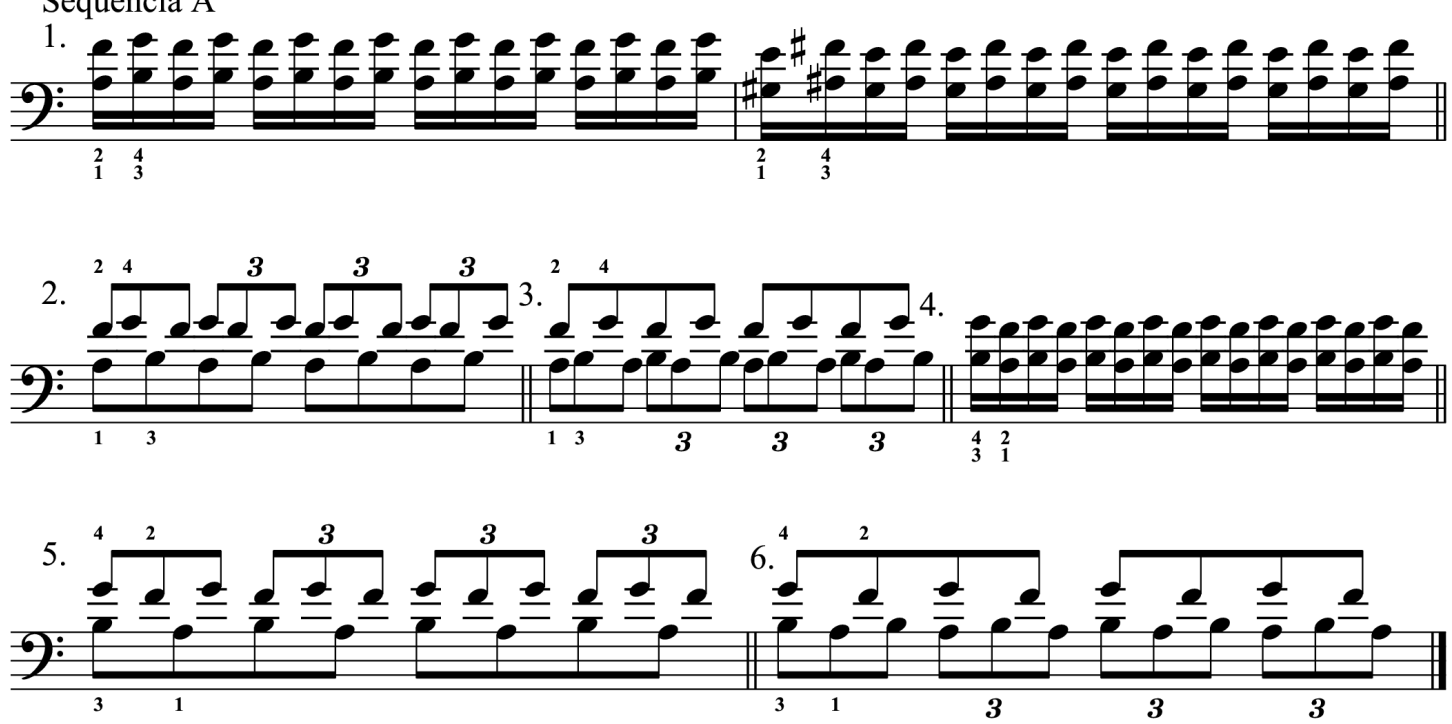


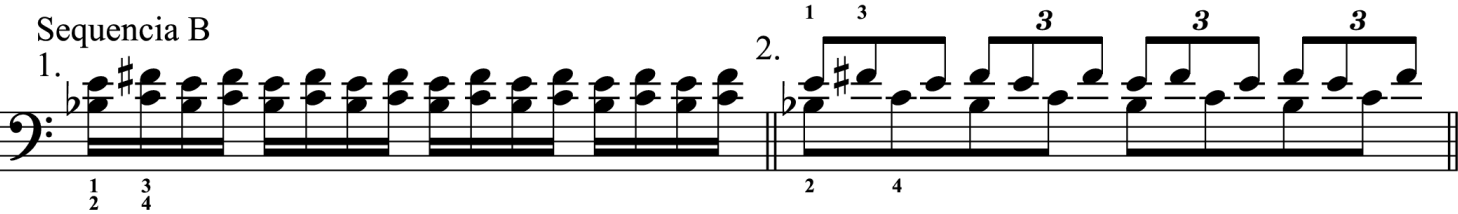

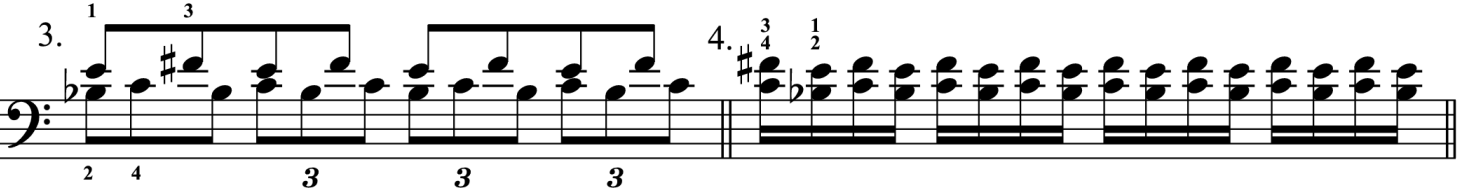

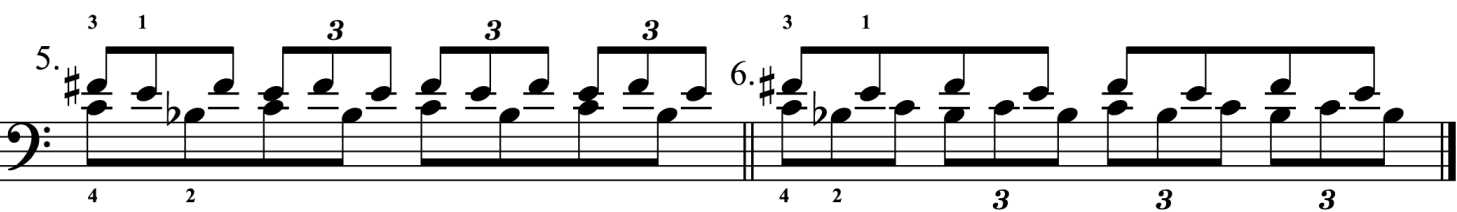

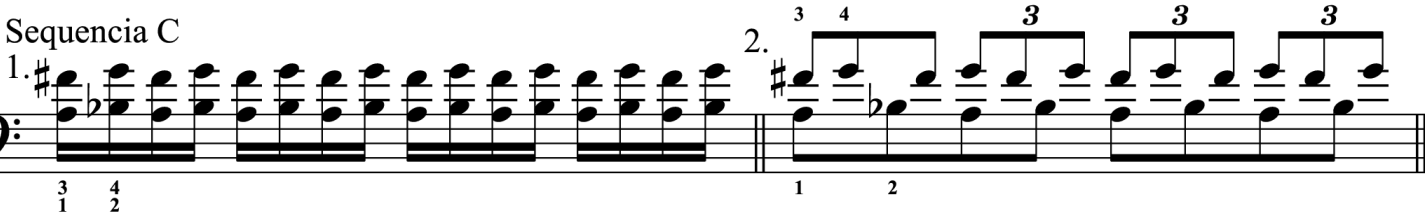

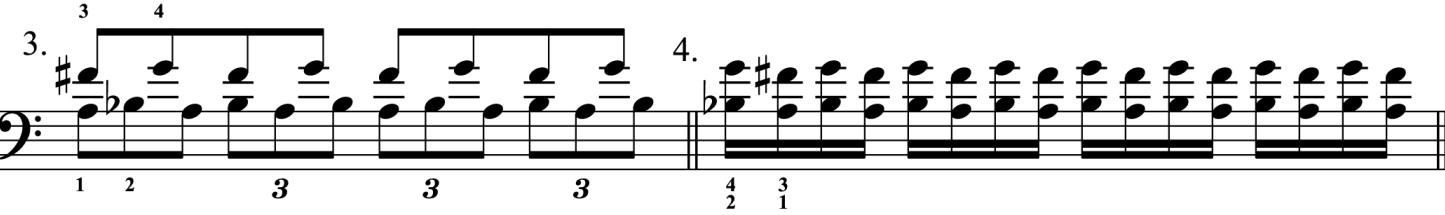

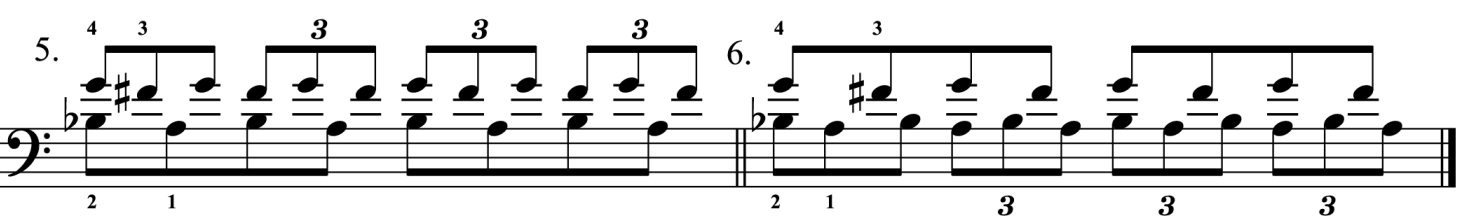

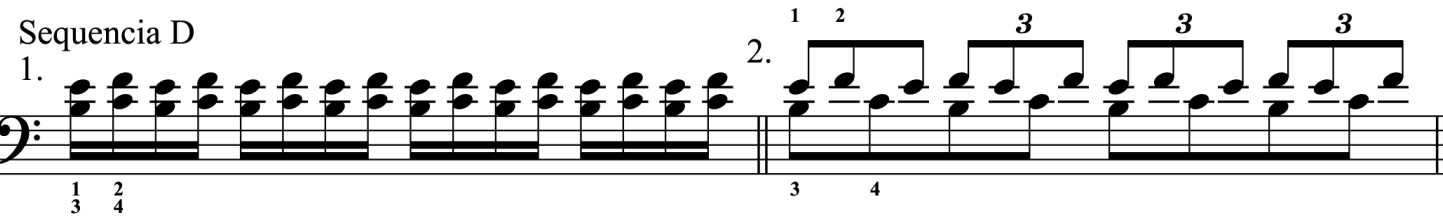

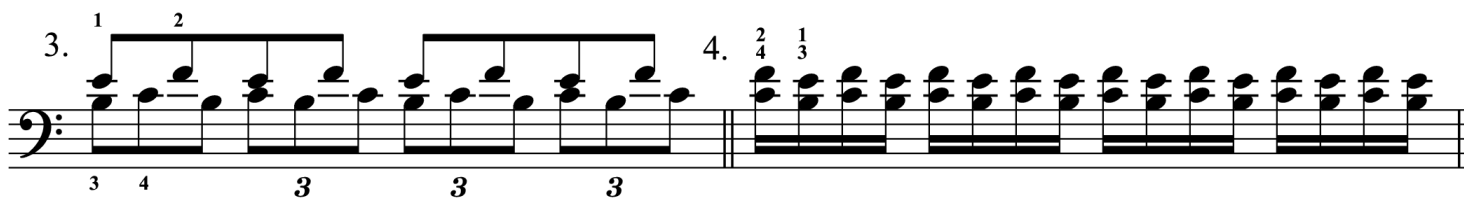

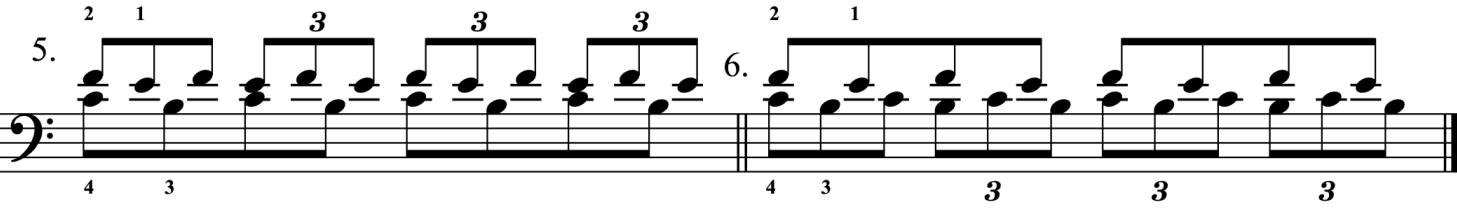


2. Cópia dos exercícios originais de Rostropovich (escaneados) 
sul C $\begin{array}{r}12412412412413413121231212123 \\ \quad \\ \hline\end{array}$

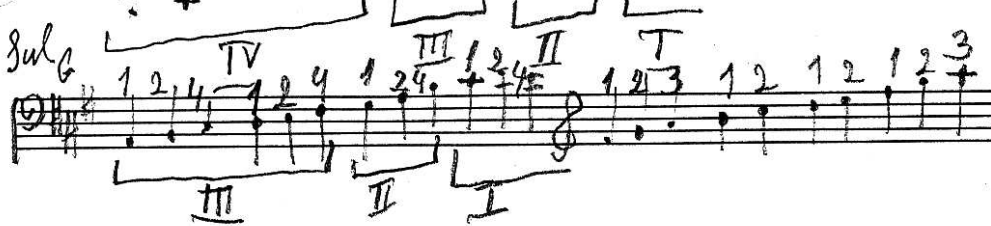

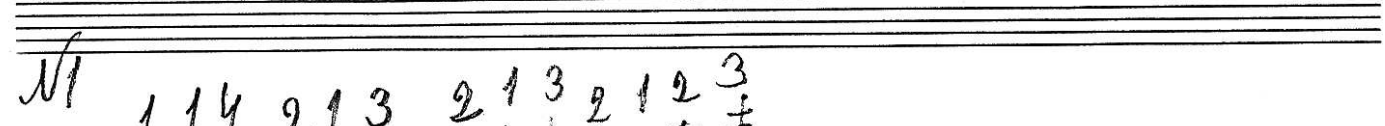
$1142321+1$
+ ${ }_{\text {IV }}^{*} I_{\text {II I }}$

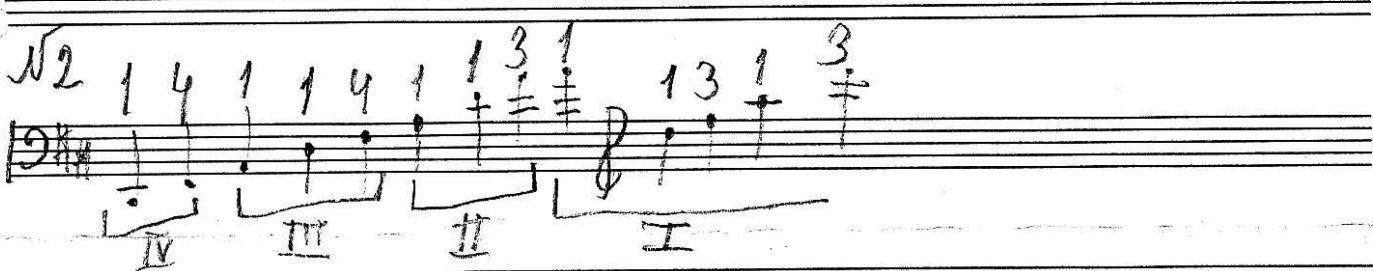

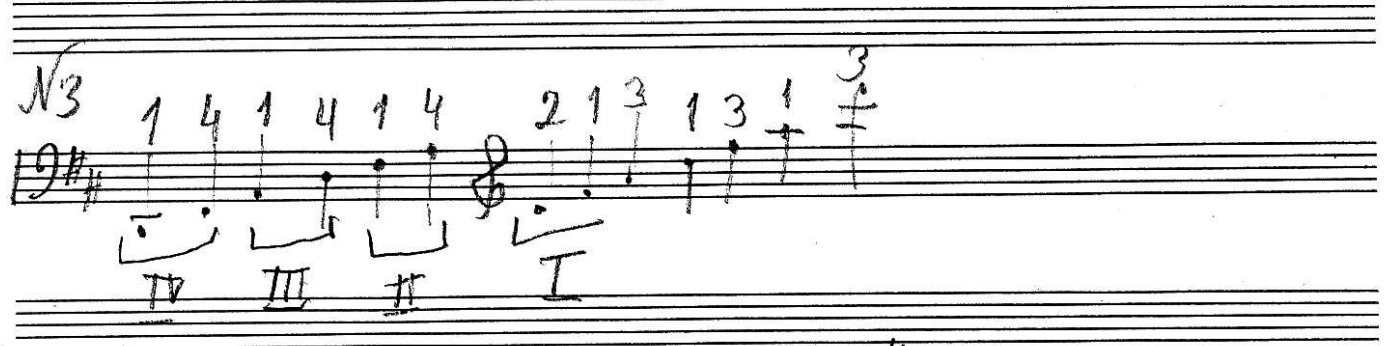

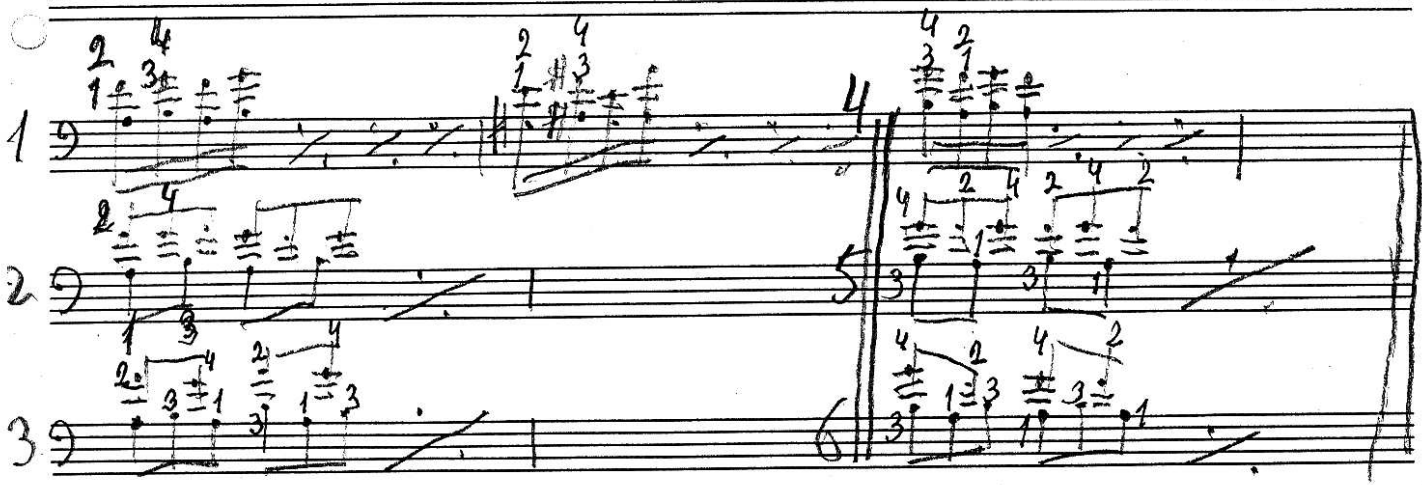



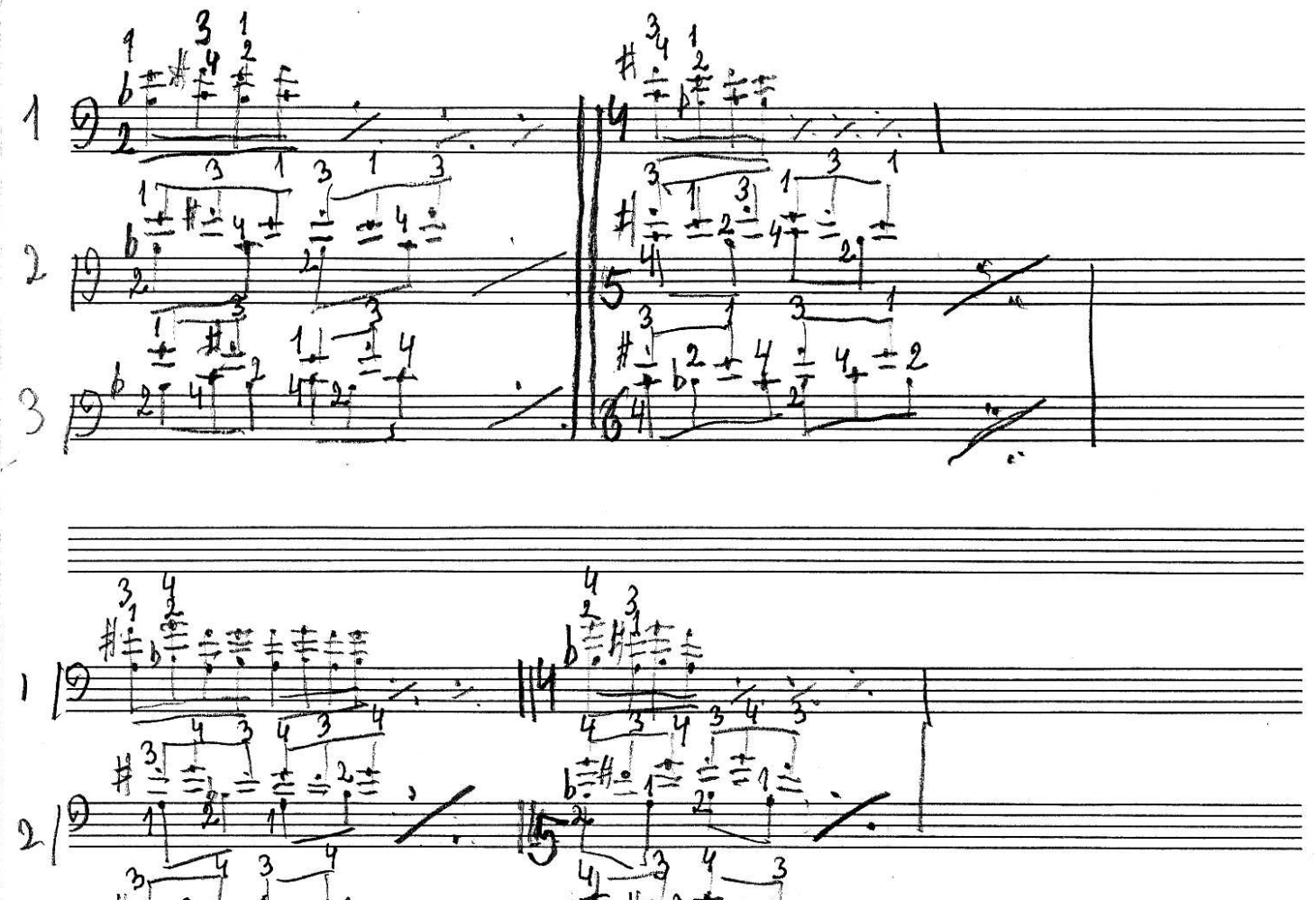

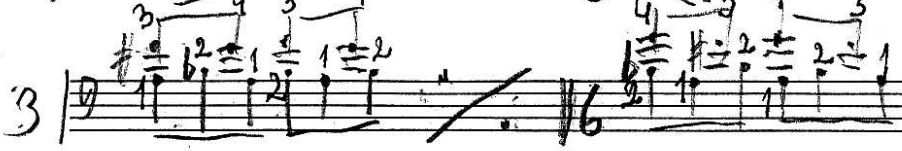

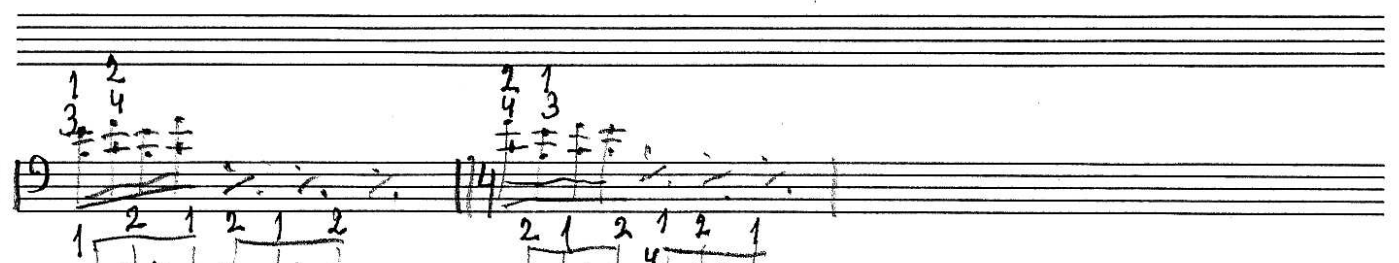

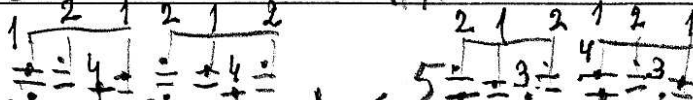

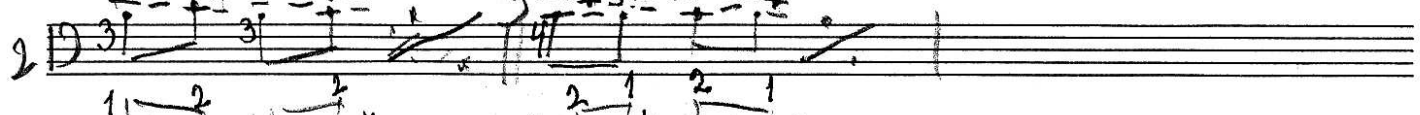
$3 \sqrt{3}$ $\pm y^{2}=3 \div 4,6 \div 4+4+3$ 
3. Escolas de Técnica de Violoncelo, por Dmitry Markevitch 


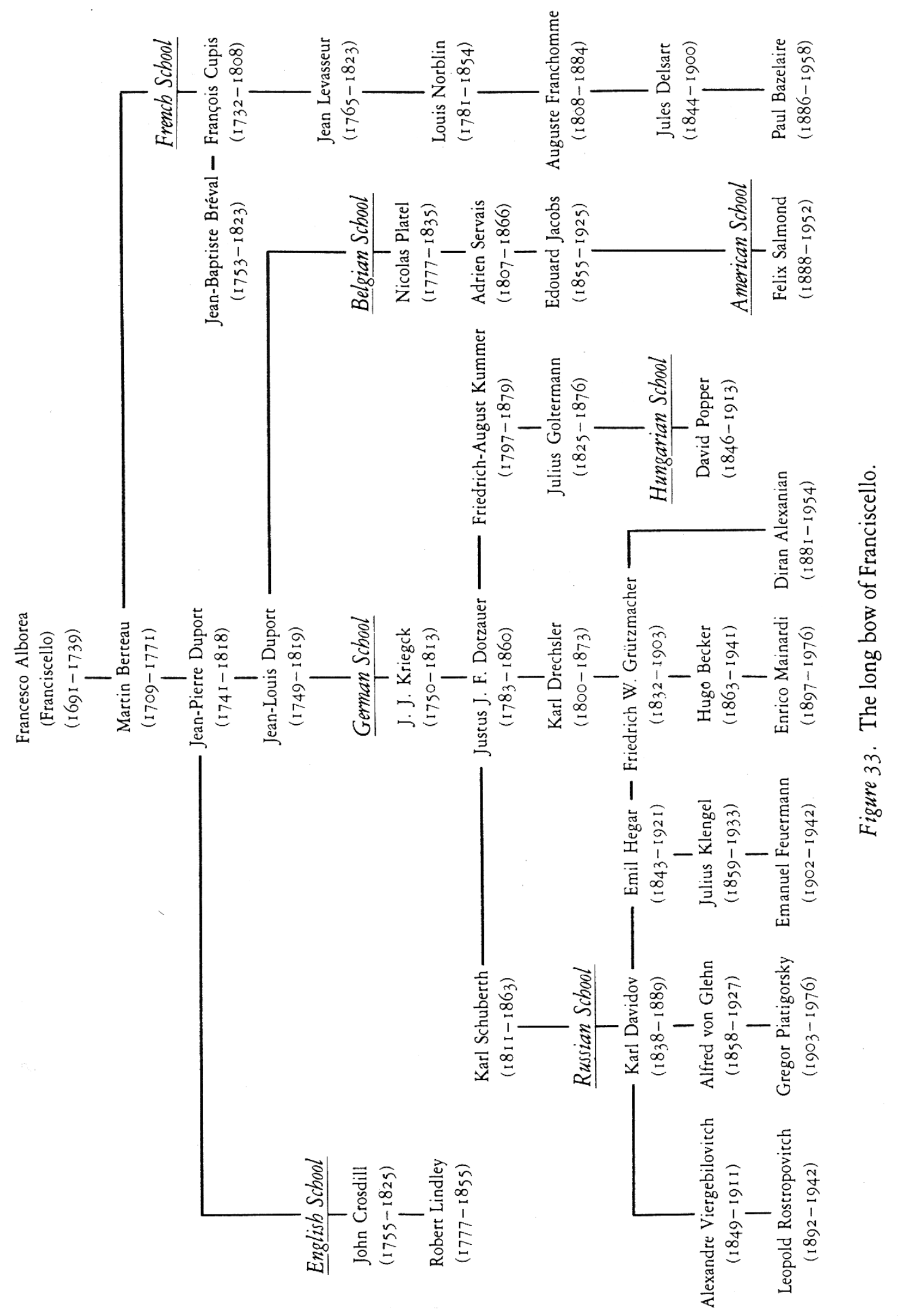

